Prepared in cooperation with the

District Department of the Environment

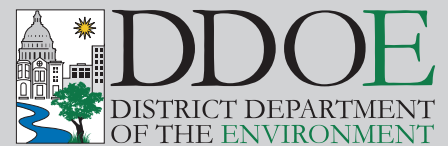

\title{
Pesticides in Groundwater in the Anacostia River and Rock Creek Watersheds in Washington, D.C., 2005 and 2008
}
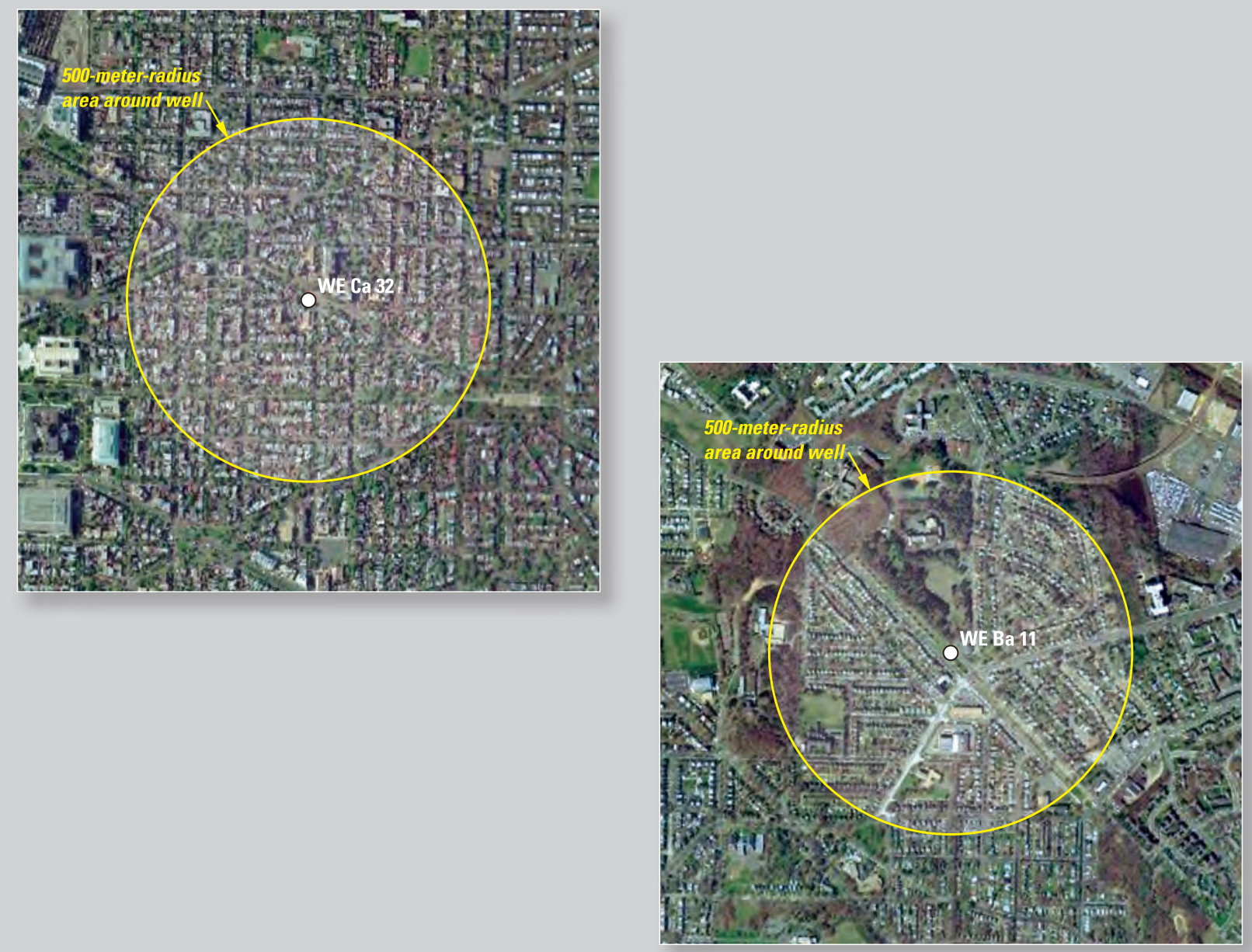

Scientific Investigations Report 2010-5130

U.S. Department of the Interior

U.S. Geological Survey 
Cover. Examples of extensively developed land within 500 meters of two wells, WE Ca 32 and WE Ba 11, which in 2008 yielded groundwater samples that contained mixtures of six or more different pesticide compounds, lower Anacostia River watershed, Washington, D.C. [Aerial photographs from U.S. Department of Agriculture (USDA) National Agriculture Imagery Program (NAIP).] 


\section{Pesticides in Groundwater in the Anacostia River and Rock Creek Watersheds in Washington, D.C., 2005 and 2008}

By Michael T. Koterba, Cheryl A. Dieter, and Cherie V. Miller

Prepared in cooperation with the

District Department of the Environment

Scientific Investigations Report 2010-5130 


\section{U.S. Department of the Interior \\ KEN SALAZAR, Secretary \\ U.S. Geological Survey \\ Marcia K. McNutt, Director}

U.S. Geological Survey, Reston, Virginia: 2010

For more information on the USGS - the Federal source for science about the Earth, its natural and living resources, natural hazards, and the environment, visit http://www.usgs.gov or call 1-888-ASK-USGS

For an overview of USGS information products, including maps, imagery, and publications, visit http://www.usgs.gov/pubprod

To order this and other USGS information products, visit http://store.usgs.gov

Any use of trade, product, or firm names is for descriptive purposes only and does not imply endorsement by the U.S. Government.

Although this report is in the public domain, permission must be secured from the individual copyright owners to reproduce any copyrighted materials contained within this report.

Suggested citation:

Koterba, M.T., Dieter, C.A., and Miller, C.V., 2010, Pesticides in groundwater in the Anacostia River and Rock Creek watersheds in Washington, D.C., 2005 and 2008: U.S. Geological Survey Scientific Investigations Report 2010-5130, $90 \mathrm{p}$. 


\section{Contents}

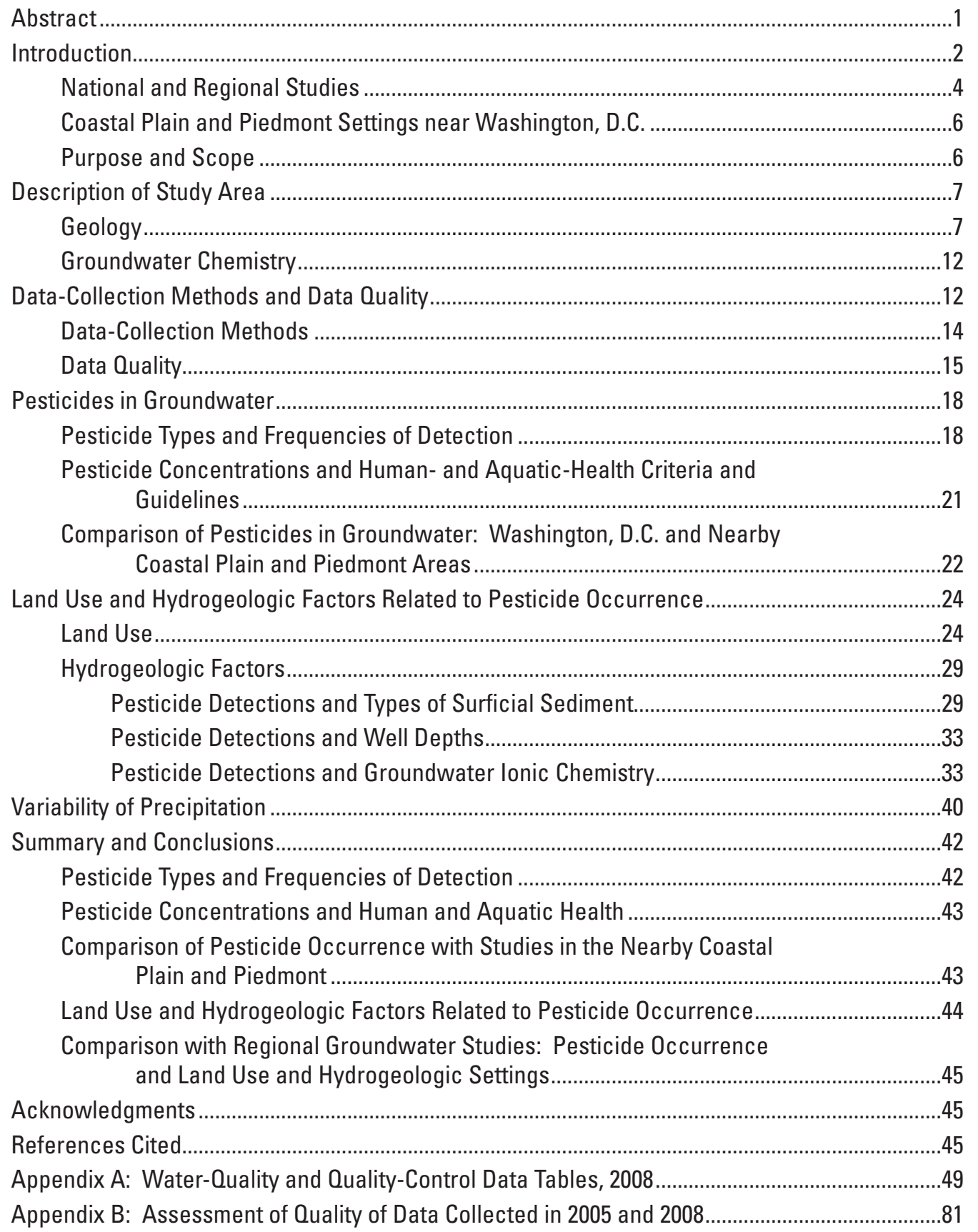




\section{Figures}

1-2. Maps showing -

1. Location of study area, including lower parts of the Anacostia River and Rock Creek watersheds, and Federal and other parklands in Washington, D.C.

2. Geology of Washington, D.C .8

3-4. Diagrams showing-

3. Generalized hydrogeologic cross sections $A-A^{\prime}$ and $B-B^{\prime}$ of the lower Anacostia River watershed, Washington, D.C.

4. Generalized geologic cross section C-C' of surficial geology of the lower Rock Creek watershed, which includes the Rock Creek shear zone, Washington, D.C.

5. Map showing estimated altitude of the regional water table and generalized direction of groundwater flow in the surficial aquifer, lower Anacostia River watershed, Washington, D.C., April 2006.

6. Trilinear diagrams showing major-ion chemistry of groundwater, by geologic unit, for the lower Anacostia River watershed, September to December 2005.

7. Graphs showing pesticide detections in groundwater samples collected in $(A) 2005$ and $(B) 2008$ in relation to the percentage of developed space (low, medium, and high-density residential, commercial, governmental, thoroughfare, and other structural) and open space (woodland, maintained grassland, and water) within 500 meters of each well used for sampling, lower Anacostia River and Rock Creek watersheds, Washington, D.C.

8-10. Aerial photographs showing-

8. Examples of extensively developed land within 500 meters of two wells, (A) WE Ca 32 and (B) WE Ba 11, which in 2008 yielded groundwater samples that contained mixtures of six or more different pesticide compounds, lower Anacostia River watershed, Washington, D.C.

9. Examples of low-to-moderately developed land within 500 meters of two wells, (A) WE Ca 34 and (B) WW Bc 11, which in 2008 yielded groundwater samples that contained no detectable pesticide compounds, lower Rock Creek and Anacostia River watersheds, Washington, D.C.

10. Examples of extensively developed land within 500 meters of two wells, (A)WE Ca 33 and (B) WW Bc 8, which in 2005 yielded groundwater samples that contained one or no detectable pesticide compounds, lower Anacostia River watershed, Washington, D.C.

11-12. Trilinear diagrams showing-

11. Pesticides in groundwater samples in relation to variations in the major-ion chemistry of groundwater associated with geologic units and sediments, lower Anacostia River and Rock Creek watersheds, Washington, D.C., 2005 and 2008

12. Changes in major-ion chemistry in groundwater samples collected from seven wells in the lower Anacostia River and Rock Creek watersheds, Washington, D.C., 2005 and 2008 
B1. Graphs showing relative percent difference as a function of mean concentration for: $(A)$ inorganic constituents (in milligrams per liter, $\mathrm{mg} / \mathrm{L}$ ) including calcium, magnesium, sodium, potassium, nitrate plus nitritenitrogen and ammonium-nitrogen, chloride, sulfate, manganese, and iron [with iron having the extreme value (40 percent) for one of two sets of duplicate measurements]; and (B) pesticides (in micrograms per liter, $\mu \mathrm{g} / \mathrm{L}$ ) including atrazine, prometon, simazine, desethylatrazine, dieldrin, fipronil, fipronil sulfone, fipronil sulfide, aminomethylphosphonic acid (AMPA), heptachlor expoxide, metolachlor, dichlorodiphenyldichloroethane ( $\left.p, p^{\prime}-D D D\right)$, and tebuthiuron

\section{Tables}

1. Identification, location, and construction information for groundwater monitoring wells in Washington, D.C. used to obtain pesticide samples from September through December 2005, and (or) August through September 2008

2. Detected pesticide compounds by type and use, detection frequency using either only or shallowest well at each site, maximum concentration, and related human- and aquatic-health concentration criteria and guidelines, for groundwater in Washington, D.C., 2005 and 2008.

3. Water-quality human- and aquatic-health assessment for groundwater samples collected from the surficial aquifer in Washington, D.C., 2005 and 2008.

4. Land use, geologic setting, and pesticide detections for groundwatermonitoring wells in Washington, D.C. sampled from September through December 2005 and (or) August through September 2008

5. Geologic formations, overburden sediment, and pesticide occurrence in groundwater samples collected from monitoring wells in Washington, D.C., 2005 and 2008.

6. Geologic setting, apparent redox state, and major-ion chemistry of groundwater samples collected in Washington, D.C., 2005 and 2008

7. Precipitation and streamflow in the Washington, D.C. greater metropolitan area, 2004 through 2008

8. Major-ion composition of groundwater samples, 2005 and 2008

A1. Concentrations of major ions, nutrients, and pesticides in groundwater samples collected in the Anacostia River and Rock Creek watersheds in Washington, D.C., August to September 2008, and selected water-quality standards

A2. Description of quality-control samples obtained in conjunction with the collection of groundwater samples in the Anacostia River and Rock Creek watersheds in Washington, D.C., August to September 2008

B1. Concentrations in field blanks and groundwater samples with constituents detected in at least one field blank collected during groundwater sampling in Washington, D.C. in 2008

B2. Means and relative percent differences in the concentrations of inorganic and organic constituents obtained from two sequential duplicate groundwater samples collected from wells in Washington, D.C. in 2008 
B3. Mean and relative standard deviation of pesticide surrogate compound recoveries for each laboratory method and from laboratory-spiked groundwater samples in 2005 and 2008, and results of the WilcoxonMann-Whitney rank sum test to determine if ranked recoveries in 2005 differed from ranked recoveries in 2008

B4. U.S. Geological Survey laboratory reporting and detection levels for pesticide schedules used in 2005 and 2008, and for which at least one pesticide was detected in a groundwater sample in 2005 or 2008.

B5. Pesticide detections and concentrations in groundwater samples collected from wells sampled in 2005 and 2008 and analyzed for similar compounds using the same laboratory schedules in 2005 and 2008

B6. Pesticide detections in groundwater attributed to the addition of a laboratory schedule (LS 2033) in 2008 that was not used in 2005, or the addition of new pesticide compounds into laboratory schedules

\section{Conversion Factors and Datums}

\begin{tabular}{|c|c|c|}
\hline Multiply & By & To obtain \\
\hline \multicolumn{3}{|c|}{ Length } \\
\hline inch (in.) & 2.54 & centimeter $(\mathrm{cm})$ \\
\hline inch (in.) & 25.4 & millimeter $(\mathrm{mm})$ \\
\hline foot $(\mathrm{ft})$ & 0.3048 & meter $(\mathrm{m})$ \\
\hline mile (mi) & 1.609 & kilometer (km) \\
\hline yard (yd) & 0.9144 & meter $(\mathrm{m})$ \\
\hline centimeter $(\mathrm{cm})$ & 0.3937 & inch (in.) \\
\hline millimeter (mm) & 0.03937 & inch (in.) \\
\hline meter (m) & 3.281 & foot $(\mathrm{ft})$ \\
\hline kilometer $(\mathrm{km})$ & 0.6214 & mile (mi) \\
\hline \multicolumn{3}{|c|}{ Area } \\
\hline acre & 0.004047 & square kilometer $\left(\mathrm{km}^{2}\right)$ \\
\hline section ( 640 acres or 1 square mile) & 259.0 & square hectometer $\left(\mathrm{hm}^{2}\right)$ \\
\hline square mile $\left(\mathrm{mi}^{2}\right)$ & 259.0 & hectare (ha) \\
\hline square mile $\left(\mathrm{mi}^{2}\right)$ & 2.590 & square kilometer $\left(\mathrm{km}^{2}\right)$ \\
\hline
\end{tabular}

Temperature in degrees Celsius $\left({ }^{\circ} \mathrm{C}\right)$ may be converted to degrees Fahrenheit $\left({ }^{\circ} \mathrm{F}\right)$ as follows:

$$
{ }^{\circ} \mathrm{F}=\left(1.8 \times{ }^{\circ} \mathrm{C}\right)+32
$$

Vertical coordinate information is referenced to the North American Vertical Datum of 1988 (NAVD 88).

Horizontal coordinate information is referenced to the North American Datum of 1983 (NAD 83).

Altitude, as used in this report, refers to distance above the vertical datum.

Specific conductance is given in microsiemens per centimeter at 25 degrees Celsius $(\mu \mathrm{S} / \mathrm{cm}$ at $\left.25^{\circ} \mathrm{C}\right)$.

Concentrations of chemical constituents in water are given either in milligrams per liter ( $\mathrm{mg} / \mathrm{L}$ ) or micrograms per liter $(\mu \mathrm{g} / \mathrm{L})$. 




\title{
Pesticides in Groundwater in the Anacostia River and Rock Creek Watersheds in Washington, D.C., 2005 and 2008
}

\author{
By Michael T. Koterba, Cheryl A. Dieter, and Cherie V. Miller
}

\section{Abstract}

The U.S. Geological Survey (USGS), in cooperation with the District Department of the Environment, conducted a groundwater-quality investigation to (a) determine the presence, concentrations, and distribution of selected pesticides in groundwater, and (b) assess the presence of pesticides in groundwater in relation to selected landscape, hydrogeologic, and groundwater-quality characteristics in the shallow groundwater underlying the Anacostia River and Rock Creek watersheds in Washington, D.C. With one exception, well depths were 100 feet or less below land surface. The USGS obtained or compiled ancillary data and information on land use (2001), subsurface sediments, and groundwater samples from 17 wells in the lower Anacostia River watershed from September through December 2005, and from 14 wells in the lower Anacostia River and lower Rock Creek watersheds from August through September 2008.

Twenty-seven pesticide compounds, reflecting at least 19 different types of pesticides, were detected in the groundwater samples obtained in 2005 and 2008. No fungicides were detected. In relation to the pesticides detected, degradate compounds were as or more likely to be detected than applied (parent) compounds.

The detected pesticides chiefly reflected herbicides commonly used in urban settings for non-specific weed control or insecticides used for nonspecific haustellate insects (insects with specialized mouthparts for sucking liquid) or termitespecific control. Detected pesticides included a combination of pesticides currently (2008) in use, banned or under highly restricted use, and some that had replaced the banned or restricted-use pesticides. The presence of banned and restricted-use pesticides illustrates their continued persistence and resistance to complete degradation in the environment. The presence of the replacement pesticides indicates the susceptibility of the surficial aquifer to contamination irrespective of the changes in the pesticides used.

A preliminary review of the data collected in 2005 and 2008 indicated that differences in the surficial geology, land use (as a surrogate for pesticide use), and above-average precipitation for most of 2004 through 2008, as well as differences in the number and performance of USGS laboratory methods used, could have led to more pesticides detected in groundwater samples collected in 2008 than in groundwater samples collected in 2005. Thus, although data from both years of collection were used for interpretive analysis, emphasis was placed on the analysis of the data obtained in 2008 .

The presence of pesticides in shallow groundwater (less than approximately $100 \mathrm{ft}$ (feet), or $30 \mathrm{~m}$ (meters), below land surface) indicated at least the upper surficial aquifer in Washington, D.C. was susceptible to contamination. One or more herbicides or insecticides were detected in groundwater samples collected from 50 percent of the shallow wells sampled in 2005, and from 62 percent of the shallow wells sampled in 2008.

Differences among types of pesticides in shallow groundwater were apparent. The most frequently detected class of herbicides was the $s$-triazine compounds - atrazine, simazine, or prometon, or the atrazine-degradate compounds-2-chloro4-ethylamino-6-amino-s-triazine (desethylatrazine or CIAT) and 2-chloro-4-isopropylamino-6-amino-s-triazine (hydroxyatrazine or OIET). The next most frequently detected classes of herbicides were the chloroacetanilides, including metolachlor and acetochlor, and the ureic herbicides, including diuron (and degradate, 3,4-dichloroaniline), fluometuron, metsulfuron methyl, sulfameturon, bromacil, and tebuthiuron.

Insecticides also were detected, but less frequently than herbicides, with one or more insecticides present in groundwater samples from 38 percent of shallow wells sampled in 2008. Detected insecticides included parent or degradate compounds commonly used for either nonspecific or haustellate (sucking) insects, including chlorpyrifos and dichlorodiphenyldichloroethane (p,p'-DDD; a degradate of dichlorodiphenyltrichloroethane, DDT), and for termite control, including dieldrin, chlordane, heptachlor epoxide, (a degradate of heptachlor), fipronil, and the sulfone and sulfide degradates of fipronil.

The concentrations of individual pesticides in shallow groundwater in both years were low. Maximum concentrations were no greater than a few tenths of a microgram per liter $(\mu \mathrm{g} / \mathrm{L})$; typical concentrations often were less than 
$0.1 \mu \mathrm{g} / \mathrm{L}$. Multiple pesticides, however, commonly were present in groundwater. For example, in 2008, approximately 88 percent (7 of 8) of the wells that yielded a sample with at least one detectable pesticide contained five or more pesticides. The highest number of detections occurred in a groundwater sample from well WE Ca 32, which is located in a highly developed urban area; this sample contained 15 different pesticide residues.

In relation to human and aquatic health, no pesticide concentration in either 2005 or 2008 exceeded Federal drinkingwater standards. Groundwater samples from a few sites, however, contained levels of chiefly banned or restricted-use pesticides that exceeded other human-health and (or) aquatichealth guidelines. For example, concentrations of dieldrin in 2008 groundwater samples from three wells-WE Ca 32 $(0.028 \mu \mathrm{g} / \mathrm{L})$, WE Ba $11(0.016 \mu \mathrm{g} / \mathrm{L})$, and WW Ac $8(0.014$ $\mu \mathrm{g} / \mathrm{L}$ ) - fell within the range of concern for 2004 Federally approved non-regulatory USGS Health-Based Assessment benchmarks ( 0.002 to $0.2 \mu \mathrm{g} / \mathrm{L}$ ), and exceeded earlier (1999) Federal criteria for drinking water $(0.000052 \mu \mathrm{g} / \mathrm{L})$. Other individual compounds whose concentrations exceeded 1999 Federal guidelines for samples from one or more of these three sites, or another site, included p,p'-DDD, dichlorodiphenyldichloroethylene ( $\mathrm{p}, \mathrm{p}$ '-DDE; another degradate of DDT), chlordane, and heptachlor epoxide. Pesticide concentrations in groundwater also were compared to three aquatic-health guidelines for freshwater (United States, Great Lakes, or Canada). One or more of these guidelines were exceeded in groundwater samples obtained in 2005 or 2008 for one or more of the compounds chlordane, dieldrin, heptachlor epoxide, $p, p^{\prime}-D D E, p, p '-D D D$, and chlorpyrifos.

The spatial distribution of pesticides in the shallow groundwater appeared to be related, in part, to land use, a surrogate for pesticide use. Although most of the wells sampled in this study are in parklands or other relatively open and accessible space, multiple pesticides most often were detected in 2008 groundwater samples collected from wells where a considerable percentage (in excess of 60 percent) of the land within a $500-\mathrm{m}$ radius is developed space (residential, commercial, or other urban infrastructure). Insecticides were detected in wells surrounded by at least 50 percent, and most commonly by more than 80 percent, development. Well WE $\mathrm{Ca} 32$, the site associated with the highest number of pesticide residues in groundwater ( 8 herbicides and 7 insecticides), is in a small residential park, where 99 percent of the surrounding land is well-maintained residential and commercial development.

The vertical distribution of detected pesticides in shallow groundwater appeared to be related, in part, to depth below land surface, surficial-bedrock type, and differences in the chemistry of shallow groundwater. Pesticides were detected at relatively shallow depths in wells that may not have fully penetrated the shallow aquifer. For wells in which at least one pesticide was detected, the median depth below land surface to the top of the well screen was $5.8 \mathrm{~m}$, and the maximum depth was $8.5 \mathrm{~m}$.
Among the types of surficial materials in which wells were completed - alluvium, terrace deposits, or Potomac Formation sub- or outcrops in the Coastal Plain Province, and saprolite or fractured bedrock (Laurel and Sykesville Formations) underlying saprolite in the Piedmont Provinceno pesticides were detected in groundwater associated with wells completed in the alluvium or fractured bedrock. Detections occurred in some but not all wells completed in the other surficial materials. Overall, the pattern in occurrence appeared related to the local permeability of these sediments and groundwater chemistry. Groundwater with multiple pesticide detections tended to occur in permeable sediments (absent any appreciable overlying clay, silt, or clay-silt layers), in conjunction with other common urban contaminants (elevated chloride in excess of tens to hundreds of milligrams per liter $(\mathrm{mg} / \mathrm{L})$, and oxic, rather than reduced, groundwater as evidenced by elevated (in excess of $5 \mathrm{mg} / \mathrm{L}$ ) concentrations of nitrate).

The results of this investigation were compared to results from two other similar and recent studies on pesticide occurrence in the shallow aquifer. These included a study in the nearby Maryland and Delaware Coastal Plain Physiographic Province and one in the Maryland and Virginia Piedmont Physiographic Province. Results from these studies were similar to the current study in relation to (a) the types, frequencies, concentrations, and mixtures of pesticides detected; (b) compounds that exceeded human-and aquatic-health criteria; and (c) the occurrence and distribution of pesticides within the surficial aquifer in relation to depths, sediment types, and groundwater chemistries.

\section{Introduction}

Potential contamination of shallow groundwater (defined in this report as 100 feet or less below land surface) by pesticides within the Piedmont and Coastal Plain Physiographic Provinces that underlie the Anacostia River and Rock Creek watersheds in Washington, D.C. (fig. 1) is of interest for two reasons. First, in the part of Washington, D.C. underlain by Piedmont rocks, the aquifer chiefly consists of in-situ weathered rocks (saprolite) and the underlying shallow fractured bedrock, which are the only major water-bearing units for groundwater supplies. In the part of Washington, D.C. underlain by Coastal Plain sediments, the surficial aquifer is the main source of recharge to deeper confined aquifers, which are major sources of groundwater for drinking or other supplies in the region. Second, the surficial aquifer is a major source of base flow to local streams within Washington, D.C., including the Anacostia River and Rock Creek (fig. 1). This base flow helps to maintain streamflows during dry weather into important estuaries - the Anacostia and Potomac Rivers, and ultimately the Chesapeake Bay. Thus, the quality of groundwater discharged from the surficial aquifer into streams in Washington, D.C. plays a role in the ecological health of local as well as larger downstream surface-water bodies. 


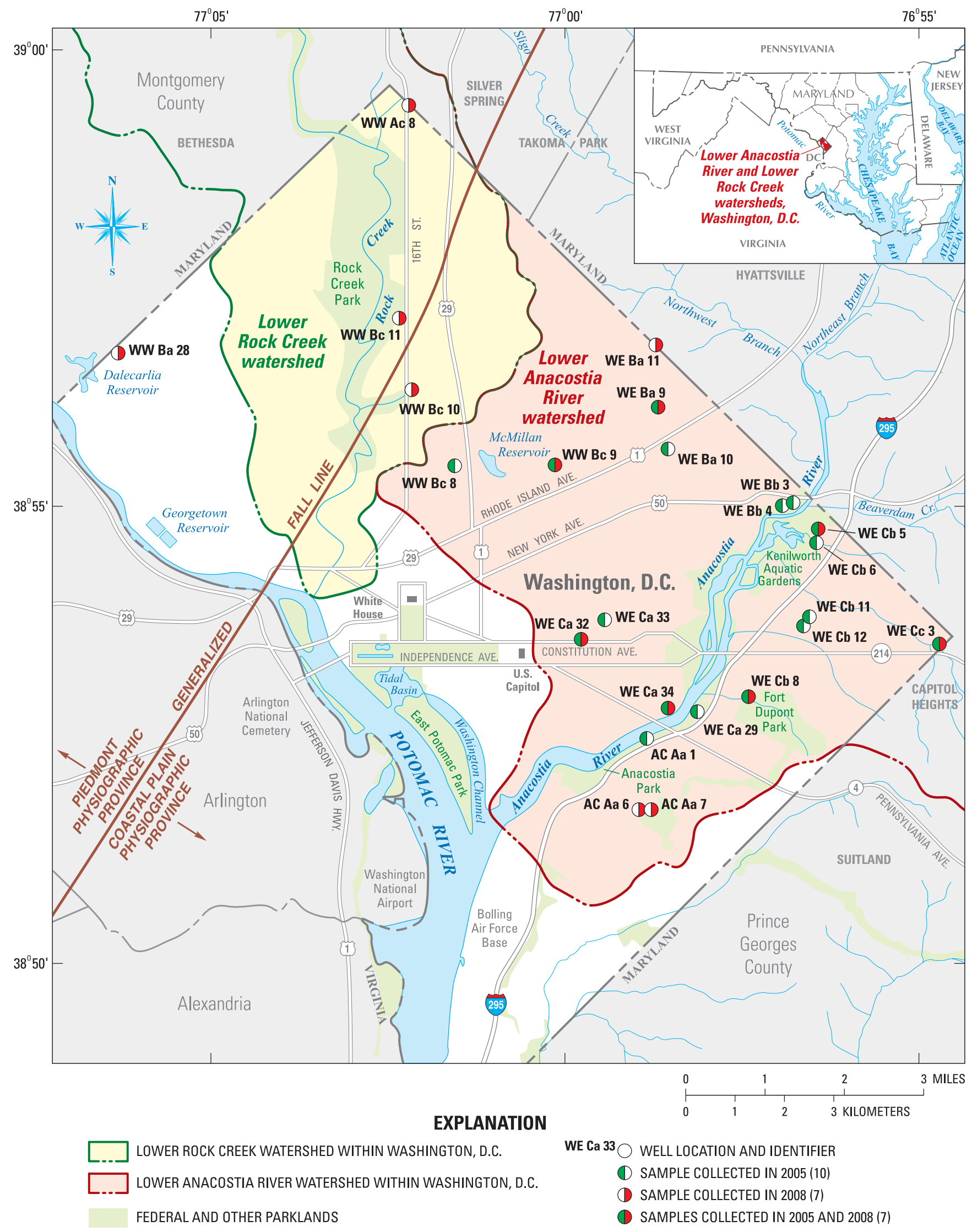

Figure 1. Location of study area, including lower parts of the Anacostia River and Rock Creek watersheds, and Federal and other parklands in Washington, D.C. 
Pesticides in Groundwater in the Anacostia River and Rock Creek Watersheds in Washington, D.C., 2005 and 2008

Both Anacostia Park and Rock Creek Park, including their streams (fig. 1), are considered local resources by Washington, D.C. residents. Anacostia Park is managed by the National Park Service (NPS), and since the late 1980s, organizations such as the Anacostia Watershed Restoration Committee (AWRC) and the Anacostia Watershed Toxics Alliance (AWTA) have facilitated efforts to rehabilitate the watershed. Recent improvements in the Anacostia River include wetland and riparian-zone restoration, trash and debris reduction, replacement of leaking sewer infrastructure, and low-impact development (LID) that uses passive engineering improvements to redirect and process storm runoff (Metropolitan Washington Council of Governments (MWCOG), 1998, 2003; Anacostia Watershed Toxics Alliance, 2001).

The activities of the NPS, AWRC, AWTA, MWCOG, and citizens groups in Washington, D.C. reflect their concerns regarding the quality of park waters. Miller and others (2007) recently described some of the adverse water-quality conditions in Anacostia watershed streams, noting that this watershed is listed as one of three Regions of Concern by the Chesapeake Bay Program (CBP). The latter program has stressed that segments of the river are on Maryland's 303(d) list for a number of contaminant issues, including bacteria, biological integrity, polychlorinated biphenyls (PCBs), and the pesticide heptachlor epoxide (Chesapeake Bay Program, 2000). Recent studies by Pinkney and others $(2001,2004)$ reported severe chemical effects on brown bullhead in the Anacostia River in Washington, D.C., and stated that the likely causative chemicals for the observed diseases in brown bullhead in the Anacostia River are polyaromatic hydrocarbons (PAHs), DDT, PCBs, and (or) chlordane.

Sedimentation remains a continuous and serious problem in the Anacostia River because of development. There has been a substantial narrowing of the Anacostia River channel (Williams, 1977). Yorke and Herb (1978) documented large increases in land clearing for urban and suburban development in the upper Northwest Branch of the Anacostia during the 1960s and 1970s, and noted that this resulted in increased sediment loads in the urbanized areas of the watershed. They found that 73 percent of the annual load occurred during flows whose duration amounted to just 2.2 percent of the year, and 94 percent of the annual load occurred during flows whose duration amounted to just 5.7 percent of the year. Yorke and Herb (1978) also concluded that major sources of sediment in the watershed were cropland, urban land, and construction sites.

Rock Creek and Rock Creek Park are managed by the NPS and the Maryland-National Capital Park and Planning Commission. Concerns have arisen regarding the quality of creek water. Although the effects of human activities on stream biota in Rock Creek Park possibly are not as severe as those found in the Anacostia River, several studies have demonstrated that many anthropogenic chemicals are present at relatively low to moderate concentrations in the bed sediments and the creek water (CH2M Hill, 1977; Anderson and others,
2002; Miller and others, 2007; Phelan and Miller, in press). This has raised concerns among Washington, D.C. residents about the quality and chemistry of surface water and groundwater in Rock Creek Park and the watershed.

\section{National and Regional Studies}

As of 2005, little data and information were available to assess pesticide contamination of the surficial aquifer underlying Washington, D.C. Since the mid-1980s, however, investigations by the USGS National Water-Quality Assessment (NAWQA) Program and others have documented the presence and distribution of pesticides, and identified landscape and subsurface characteristics related to their presence, in surficial aquifers throughout the Nation, including the Coastal Plain near Washington, D.C. The evidence of possible adverse effects on groundwater quality in surficial aquifer settings described in NAWQA studies, combined with greater Federal regulation of pesticides in groundwater, and the lack of information and data on pesticides in groundwater within Washington, D.C., have been catalysts for this study, which was conducted by the USGS, in cooperation with the District Department of the Environment (DDOE) in 2005 and 2008.

From a national perspective, and given the abundance of row crops, pastureland, livestock, and other agricultural activities in the Nation, the occurrence and distribution of selected pesticides (parent and degradate compounds) in shallow groundwater beneath agricultural areas, including the Coastal Plain Physiographic Province in Maryland, have been examined through several NAWQA studies (Ator, 2008; Denver and Ator, 2006; Gilliom and others, 2006; Kiely and others, 2004; Kolpin and others, 1997; Shedlock and others, 1999; Barbash and Resek, 1996; Gilliom and others, 1995). Additional NAWQA or other national and regional studies have addressed the occurrence and distribution of pesticides in shallow groundwater beneath urban areas - residential, commercial, and industrial - including the Coastal Plain (Ator, 2008; Flanagan and others, 2001; Andrews and others, 1998; Berndt and others, 1998; Ator and Denis, 1997, Kolpin and others, 1997; and Bruce, 1995).

General results from these studies in agricultural and urban settings that are relevant to Washington, D.C. are as follows:

a. Pesticides have been used in large metropolitan areas similar to Washington, D.C., as well as in agricultural areas, and their use likely will continue in order to control pests in these settings;

b. Shallow groundwater beneath large metropolitan areas similar to Washington, D.C., as well as beneath agricultural areas, has been contaminated by modern (post-1940s) pesticides;

c. The types, occurrence, and distribution of pesticides in shallow groundwaters reflect patterns in land use and pesticide application, the chemical and physical prop- 
erties of different pesticides, and natural factors - for example, rainfall amounts and soil or sediment permeability - all of which collectively determine the fate and movement of pesticides in these environments;

d. The pesticides that have been most frequently detected generally are among the most frequently used, are relatively water soluble, and are highly mobile or at least highly persistent (resistant to degradation) in the environment;

e. The detected pesticides often include degradate forms, whose individual concentrations can exceed the concentrations of the applied parent forms of the compounds; and

f. Pesticides often are found at low concentrations, in mixtures, and with few exceedances of regulatory standards or guidelines for human and aquatic health, but for many of the detected parent or degradate compounds or mixtures of compounds, there are no standards or guidelines.

For example, nationally, in 2000 and 2001, approximately 75 percent of all pesticide use for weed and insect control was agricultural. The other 25 percent of pesticide use occurred in nonagricultural settings - residential, commercial, industrial, transportation, public-health, and other nonagricultural applications (Kiely and others, 2004). In addition, Kiely and others (2004) noted that approximately 40 percent of all fungicide use in the Nation occurred in nonagricultural settings.

The apparent relation between pesticide detections and pesticide mobility has been described by Barbash and Resek (1996). Mobility of a pesticide appears to be related to its solubility in water and its ability to move (partition) among different environmental media - air, water, soil, and biota. For example, a pesticide that is highly soluble in water, but does not readily volatilize or strongly sorb to organic matter, is apt to be detected in groundwater. A highly volatile pesticide that readily passes into the air, or a pesticide that strongly binds to organic matter in the soil, is unlikely to be detected in groundwater.

Persistence also appears to play a role in pesticide detectability (Barbash and Resek, 1996). A pesticide that is highly resistant to degradation is considered persistent, and can remain detectable in the environment (air, soil, or water) for years to decades after application.

A pesticide often is transformed into one or more compounds commonly referred to as degradates. Furthermore, most pesticide degradation appears to occur in the soil zone where abiotic chemical and biotic (animal, plant, or microbial) processes are most active (Barbash and Resek, 1996).

Upon transformation of the parent compound, a variety of degradates can form before the soil water that contains these degradates percolates through the vadose zone and reaches the water table. Thus, degradation could make detection of the applied form of the pesticide difficult; there could be multiple degradate forms of the pesticide present whose detectability depends on the state of current analytical methods.

Whether or not a water-soluble pesticide (parent or degradate compound) is mobilized depends in part on the ease with which water can infiltrate and percolate through the soil and surficial sediments. As noted earlier, national and regional studies have found pesticides generally are present most frequently in shallow groundwater beneath well-drained areas with highly permeable sandy soils and with sand and gravel aquifers; permeable shallow sediments occur commonly in Washington, D.C.

Whether the pesticides present in groundwater are cause for concern is the subject of considerable debate. In the previously cited national and regional studies, this concern chiefly was addressed on the basis of whether or not the detected pesticide compound(s) occurred at concentrations that are known or deemed likely to result in human-health or ecological effects. For human-health regulated compounds, the basis for comparison generally has been Federal drinkingwater standards (for example, U.S. Environmental Protection Agency, 2004). For selected compounds not covered by drinking-water standards, the U.S. Environmental Protection Agency (USEPA) initially provided recommendations (U.S. Environmental Protection Agency, 1999) and recently approved Health Assessment benchmarks developed by the USGS (Toccalino and others, 2004) to assess groundwater quality. In the national and regional studies noted earlier, pesticide compounds that are toxic or known or suspected carcinogens were present in shallow groundwater. In addition, other pesticide (parent and degradate) compounds, whose potential human-health effects, individually or as collective mixtures, are largely unknown, also were present in groundwater.

For ecological health, the basis for comparisons has varied and included USEPA national recommended long-term aquatic chronic-exposure criteria for continuous concentrations in freshwater (U.S. Environmental Protection Agency, 1999), the U.S. and Canada International Joint Commission (International Joint Commission, 1989) Great Lakes aquatichealth objectives, and Canadian guidelines for the protection of aquatic health (Canadian Council of Ministers of the Environment, 2007). In addition, a number of other pesticides (parent and degradate) compounds, whose potential aquatichealth effects, individually or as collective mixtures, are largely unknown, were present in groundwater.

Exceedances of either human- or aquatic-health guidelines are a concern in the Anacostia River and Rock Creek in Washington, D.C., and therefore were considered in this study. Groundwater that contains concentrations of pesticides that exceed Federal drinking-water standards could prevent the use of this water as an alternative source of public drinking water in the future. In addition, there could be human-health implications where local supplies (such as private domestic-use wells) are not regulated or routinely monitored. Exceedances of aquatic-health guidelines also are of concern in Washington, D.C. because of the potential implications for the health of local streams, estuaries, and the Chesapeake Bay. 


\section{Coastal Plain and Piedmont Settings near Washington, D.C.}

National and regional studies can provide a broad indication of the types, occurrence, and distribution of pesticides detected in shallow groundwaters in different climatic, land-use, and hydrogeologic settings, and help to identify factors that could influence the occurrence, fate, and transport of pesticides to shallow groundwater. Therefore, the regional and local studies that have been conducted near and in Washington, D.C. and in Maryland, Virginia, and Delaware, and in relation to shallow groundwater in the Coastal Plain and Piedmont Provinces, are the most relevant to this study.

From a hydrologic perspective, annual rainfall in the Maryland-Virginia-Washington, D.C. area is relatively abundant, averaging approximately 41 inches per year from 1901-2001, and is fairly well distributed throughout the year (Wheeler, 2003). About one-quarter to one-third of this annual rainfall infiltrates through the soil zone and percolates down through unconsolidated materials to recharge the unconfined surficial aquifer that underlies most of the Coastal Plain and Piedmont aquifers in this area (Denver and Ator, 2006).

Although an adequate amount of low-ionic-strength rainfall and recharge occurs in the region, a number of local and regional studies have shown that the chemistry of groundwater in the surficial aquifer beneath recharge areas, such as in the Coastal Plain in Maryland, often reflects recent human activities (Desimone and others, 2009; Ator, 2008; Debrewer and others, 2007; Klohe and Debrewer, 2007; Focazio and others, 1998, 2002). The main observed effects of human activities are elevated concentrations of chemicals (for example, nutrients and pesticides) from development and agriculture. This illustrates the susceptibility of these Coastal Plain landscapes to leaching of applied or disposed-of chemicals, including selected pesticides, during recharge to the underlying surficial aquifer.

Regional and local studies indicate that contaminated groundwater potentially can travel through the surficial aquifer and either discharge into streams or continue into outcrop or subcrop areas of the underlying confined aquifers (Potomac Formation). In either case, the time of travel could be relatively rapid. For example, Denver and Ator (2006) noted that groundwater in the surficial aquifer in the Coastal Plain of Maryland and Delaware that is contaminated with pesticides appears to be relatively young with an apparent age of 50 years or less since the time of recharge. In addition, many of the same pesticides present in shallow groundwater also are present in nearby streams during base flow in the Coastal Plain of Maryland, Delaware, and Washington, D.C. (Shedlock and others, 1999; Denver and Ator, 2006; Miller and others, 2007), which indicates relatively short times of travel.

Pesticides seldom have been detected downdip in the confined aquifers of the Coastal Plain. Ator (2008) attributed the lack of occurrence of pesticides in the confined aquifers to (a) the long times of travel for groundwater, given that the apparent age of water in the confined aquifers generally predates the use of modern pesticides, and (b) the relative impermeability of confining-bed silt and clay sediments that separate the shallow surficial aquifer from the underlying confined aquifers and the confined aquifers from one another.

Although groundwater quality in the surficial aquifer in the Coastal Plain near Washington, D.C. has been the subject of considerable investigation, less is known about the potential contamination of groundwater by pesticides in the surficial aquifer in the Piedmont Province near Washington, D.C. The most recent, relevant, and nearby study by Banks and Reyes (2009) indicates that the Piedmont surficial aquifer in Maryland and Virginia adjacent to parts of Washington, D.C. is likely as susceptible as the nearby surficial aquifer in the Coastal Plain of Maryland and Delaware to nutrient and pesticide contamination by human activities related to modern land use.

Recent and nearby studies clearly indicate the potential for human activities to adversely affect the quality of streamwater and groundwater in the surficial aquifer in the Piedmont and Coastal Plain settings in Washington, D.C. A key limitation to conducting such groundwater studies in Washington, D.C., however, has been the paucity of wells and, hence, the means to obtain data. Johnston (1964) noted this problem. He relied on historical articles and other anecdotal records to document that problems with stream and well contamination from development began affecting large communities throughout Washington, D.C. early in the 20th century. By the 1920s, many shallow wells and streams were abandoned as sources of public water supply as withdrawals of surface water for public water supplies increased from the Potomac River. By the 1960s, only a few deeply drilled and chiefly artesian wells in the Coastal Plain within Washington, D.C. continued to be used by commercial establishments. In conjunction with the increased reliance on the Potomac River rather than groundwater for public water supplies, increased development coincided with the loss of areas sufficiently accessible to install wells, which further limited the ability to conduct such studies.

\section{Purpose and Scope}

This report presents the types, frequencies of occurrence, and concentrations of selected pesticide (parent and degradate) compounds in shallow groundwater in the lower Anacostia River and lower Rock Creek watersheds within Washington, D.C. The concentrations of detected pesticides are described in relation to human- and aquatic-health criteria and guidelines. The types and frequencies of occurrence of detected pesticides are further discussed in relation to local, regional, and national studies of pesticide occurrence in groundwater that include nearby parts of the Coastal Plain and Piedmont Physiographic Provinces. In addition, the occurrence and distribution of the detected pesticides are examined in relation to local differences in land use, surficial materials, and the inorganic chemistry of groundwater associated with sampling sites distributed among both watersheds and physiographic settings within 
Washington, D.C. All data obtained in the field or from the analysis of groundwater and quality-control samples collected and analyzed in 2008 are summarized in this report.

\section{Description of Study Area}

Washington, D.C. occupies a total area of about $68.3 \mathrm{mi}^{2}$ (square miles) and is bordered by the States of Maryland to the southeast, northeast, and northwest, and Virginia to the southwest (fig. 1). As the Nation's capital, Washington, D.C. generally is perceived as a major metropolitan area, but a considerable part of the capital is water and parkland. Approximately 10 percent $\left(6.9 \mathrm{mi}^{2}\right)$ of Washington, D.C. is open water (U.S. Census Bureau, 2008), with three major natural flowing streams - the Potomac River, which forms the southern border of Washington, D.C.; the Anacostia River, which drains most of the eastern part of Washington, D.C.; and Rock Creek, which drains most of the western part of Washington, D.C. (fig. 1). About 19.4 percent $\left(13.3 \mathrm{mi}^{2}\right)$ of Washington, D.C. is parkland, and most (89 percent, $11.8 \mathrm{mi}^{2}$ ) of this parkland is managed by the NPS, including the largest parks, Rock Creek and Anacostia, as well as a number of small parks, such as the Chesapeake and Ohio Canal National Historical Park, the National Mall, and Theodore Roosevelt Island (The Trust for Public Land, 2009).

Although surface-water watersheds are used in this report to define different parts of the study area that vary in hydrogeologic characteristics, the surface-water watershed boundaries are not necessarily coincident with the shallow groundwater-flow boundaries.

\section{Geology}

Washington, D.C. is located on the transition zone between the Piedmont and Coastal Plain Physiographic Provinces (fig. 1). Deeply weathered and exposed igneous and metamorphic rocks of the Piedmont are at land surface in the western part of Washington, D.C. and dip to the southeast at about 125 feet per mile (Johnston, 1964). These rocks are overlain by an eastward-thickening wedge of unconsolidated Coastal Plain sediments composed of silts, clays, sands, and gravels that increase in thickness to more than $1,500 \mathrm{ft}$ (feet) in the southeastern Coastal Plain of Washington, D.C. This unconformity between the Piedmont and Coastal Plain Physiographic Provinces is referred to as the Fall Line (Johnston, 1964).

The physiography of Washington D.C. can be described in relation to its two major watersheds - the Anacostia River watershed to the east, and the Rock Creek watershed to the west (fig. 1). The Anacostia River watershed covers approximately $26 \mathrm{mi}^{2}$ within Washington, D.C. and lies entirely within the Coastal Plain. The Rock Creek watershed covers approximately $15.9 \mathrm{mi}^{2}$ within Washington, D.C. and includes
Piedmont rock to the west and Coastal Plain sediments to the east.

Coastal Plain sediments beneath the Anacostia River watershed form a system of confined and unconfined aquifers (S.W. Ator, U.S. Geological Survey, written commun., 2010). To the north, coarse sediments (sand-dominated lithofacies) of the Cretaceous-age Potomac Formation (Kps) form an aquifer that crops out and subcrops in the northwestern part of the watershed (fig. 2, Kps, and fig. 3, section A-A'). Downdip from the outcrop and to the southeast, the aquifer is confined by an overlying clay-dominated lithofacies (Kpc) of the Potomac Formation (fig. 2, Kpc, fig. 3, section A-A'). Downriver to the south and as the river valley widens, cross sections of the watershed show an increasing series and thickness of interbedded Tertiary and Quaternary terrace deposits (sands, silts, and clays), with local heterogeneities, including fill (fig. 2 and fig. 3, section B-B'), that form an unconfined surficial aquifer, with local perched and semi-confined conditions above the Potomac Formation (clay-dominated lithofacies).

Rock Creek watershed lies on the transition zone between the Piedmont and the Coastal Plain (figs. 1, 2). Because of historical orogenic activity, this transition zone has a complex surficial geology (Southworth and Denenny, 2006). For brevity, only formations relevant to the locations of wells used for pesticide and other water-quality sampling in the Rock Creek watershed are discussed in the current report.

Surficial geologic formations associated with well sites used in this study and in Rock Creek watershed in Washington, D.C. include the Piedmont Sykesville ( $€$ s) and Laurel $(€ l)$ Formations, and the Coastal Plain Potomac (Kp) Formation and terrace and alluvial deposits (figs. 2, 4, €s, €l, and $\mathrm{Kp}$ ). The Sykesville and Laurel Formations are the major exposed and fractured sedimentary rocks in Rock Creek watershed and where not truly exposed can be overlain by saprolite (bedrock weathered in place).

Southworth and Denenny (2006) described the Sykesville Formation in Washington, D.C. as a sedimentary mélange of a gray matrix of quartz and feldspar that supports rounded and elliptical white and clear quartz cobbles, blocks of dark gray phyllonite, light gray migmatite and metagraywacke; dark greenish black mafic, ultramafic, and metagabbro rocks; and light gray metafelsite and plagiogranite. The Sykesville Formation $(€ s)$ is exposed at the mouth of Rock Creek and trends northerly and northwesterly through the Rock Creek watershed and Washington, D.C. (figs. 2, 4, €s).

The Laurel Formation is described by Southworth and Denenny (2006) as a sedimentary mélange that is similar to some rocks in the Sykesville Formation. Rocks of the Laurel Formation have a matrix of quartz and feldspar that supports fragments, elongated cobbles, and bodies of meta-arenite and muscovite-biotite schist. The Laurel Formation $(€ l)$, however, locally consists of more than 50 percent meta-arenite clasts. This unit crops out in the Rock Creek drainage area in Klingle Valley and trends northerly through the watershed in Washington, D.C. (figs. 2, 4, €l). 


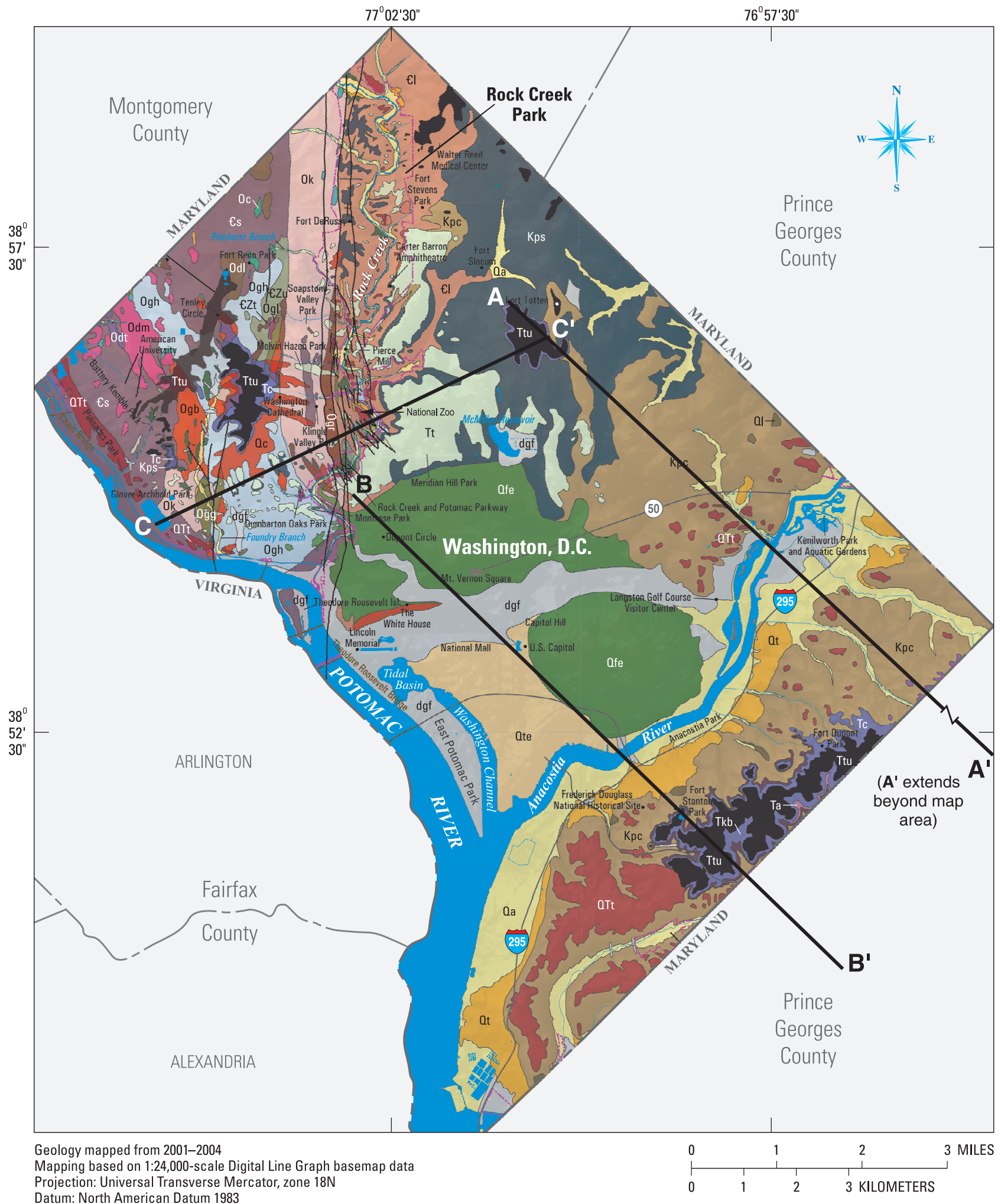

Datum: North American Datum 1983

\section{EXPLANATION}

dgf Geologic unit (Refer to geologic map units on next page.)

Faults associated with Rock Creek shear zone
$\mathbf{A}-\mathbf{A}^{\prime}$ ' Line of section A-A' (Refer to figure 3)

B - B' Line of section B-B' (Refer to figure 3)

C C C C' Line of section C-C' (Refer to figure 4)

Figure 2. Geology of Washington, D.C. (modified from Southworth and Denenny, 2006). 


\section{GEOLOGIC MAP UNITS}

QUATERNARY AND CENOZOIC SURFICIAL MATERIALS

\begin{tabular}{|c|}
\hline dgf \\
\hline Oa \\
\hline Qt \\
\hline Oc \\
\hline al \\
\hline Ote \\
\hline \hline Ofe \\
\hline OTt \\
\hline
\end{tabular}

Disturbed ground and artificial fill

Alluvium (Holocene)

Terrace deposits, low level (Holocene and Pleistocene)

Colluvium (Holocene and Pleistocene)

Landslide (Holocene and Pleistocene)

Lower-level fluvial and estuarine deposits (Pleistocene)

Upper-level fluvial and estuarine deposits (Pleistocene)

Terrace deposits, upper level (Pleistocene and Tertiary)

CENOZOIC AND CRETACEOUS COASTAL PLAIN DEPOSITS

\begin{tabular}{|c|c|}
\hline $\mathrm{Tt}$ & Terrace deposits (Tertiary) \\
\hline Ttu & Highest level upland terrace deposits (Tertiary) \\
\hline Tyb & $\begin{array}{l}\text { Yorktown Formation (Pliocene) and } \\
\text { Bacons Castle Formation (Upper Pliocene) }\end{array}$ \\
\hline Tc & Calvert Formation (Middle Miocene) \\
\hline $\mathrm{Tn}$ & Nanjemoy Formation (Lower Eocene) \\
\hline $\mathrm{Tm}$ & Marlboro Clay (Lower Eocene and Upper Paleocene) \\
\hline Ta & Aquia Formation (Upper Paleocene) \\
\hline $\mathrm{TKb}$ & $\begin{array}{l}\text { Brightseat Formation and Monmouth Group, undivided } \\
\text { (Lower Paleocene and Upper Cretaceous) }\end{array}$ \\
\hline $\mathrm{Km}$ & Monmouth Formation (Upper Cretaceous) \\
\hline Ks & Severn Formation (Upper Cretaceous) \\
\hline Kp & Potomac Formation (Lower Cretaceous) \\
\hline Kpc & Clay-dominated lithofacies \\
\hline Kps & Sand-dominated lithofacies \\
\hline \multicolumn{2}{|c|}{ PALEOZOIC ROCKS (BEDROCK) } \\
\hline $0 c$ & Clarendon Granite (Middle Ordovician) \\
\hline Ok & Kensington Tonalite (Middle Ordovician) \\
\hline \multirow[t]{2}{*}{$\mathrm{Ogl}$} & Granite (Ordovician?) \\
\hline & Dalecarlia Intrusive Suite (Early and Middle Ordovician) \\
\hline Odl & Monzogranite \\
\hline $0 \mathrm{dm}$ & Biotite monzogranite and lesser granodiorite \\
\hline \multirow[t]{2}{*}{ Odt } & Muscovite trondhjemite \\
\hline & Georgetown Intrusive Suite (Early Ordovician) \\
\hline Ogh & Biotite-hornblende tonalite \\
\hline Ogg & Quartz gabbro \\
\hline Ogb & Biotite tonalite \\
\hline Ogr & Garnetiferous biotite-hornblende tonalite \\
\hline Ogus & Soapstone and talc schist \\
\hline Ogu & Ultramafic rocks \\
\hline Ogp & Pyroxenite \\
\hline$€ s$ & Sykesville Formation (Lower Cambrian), Diamictite \\
\hline$€ l$ & Laurel Formation (Lower Cambrian) \\
\hline \multicolumn{2}{|c|}{ PALEOZOIC AND NEOPROTEROZOIC ROCKS } \\
\hline & $\begin{array}{l}\text { Metavolcanic and meta-igneous rocks of uncertain } \\
\text { origin (Lower Cambrian and Neoproterozoic) }\end{array}$ \\
\hline$€ Z u$ & Ultramafic rocks \\
\hline$€ Z \mathrm{t}$ & Soapstone, talc schist, and actinolite schist \\
\hline
\end{tabular}

Figure 2. Geology of Washington, D.C. (modified from Southworth and Denenny, 2006).-Continued
West of Rock Creek is a set of long, near-vertical faults that trends north to south (figs. 2, 4) through Washington, D.C. The fault zone is named the Rock Creek shear zone (Fleming and others, 1998), and can be considered part of the Fall Line within Washington, D.C. Streambed meanders in Rock Creek are incised along bedrock fractures that strike northwest and northeast in this zone (figs. 2, 4).

Collectively, the Piedmont rocks in Rock Creek Park (fig. 2) are foliated and dip steeply to the west with metasedimentary and metaigneous rocks strongly aligned north to south along the Rock Creek fault-shear zone. Southworth and Denenny (2006) noted that tectonic activity along this shear zone has been very complex since the first plutonic rocks appeared, and they described a system of post-Cretaceous-age, north-northwest-directed thrust faults in crystalline rocks that cut the Coastal Plain as late as $1.8 \mathrm{Ma}$ (million years ago) at the beginning of the Quaternary Period. The current distribution of Cretaceous and Tertiary deposits and Quaternary terraces indicates that the west side of the Rock Creek shear zone was uplifted, incised, and eroded more than the east side through incision by the ancestral Rock Creek and Potomac River. This erosional incision left only isolated patches of the Coastal Plain sediments, which principally appear west of the park at isolated locations-Ward and Tenley Circles, and along Wisconsin Avenue.

Coastal Plain sediments chiefly are found in the eastern part of Rock Creek watershed within Washington, D.C. The oldest Coastal Plain deposits are the Potomac Formation (fig. 2, Kp). Both sand-dominated lithofacies (Kps) and claydominated lithofacies $(\mathrm{Kpc})$ of this formation are found on the east side of Rock Creek Park. The Calvert Formation (Tc) is present only on the west side of Rock Creek Park in Cleveland Park.

Tertiary or Quaternary sediments compose at least four terrace levels along Rock Creek that Southworth and Denenny (2006) indicated could be related to the ancestral Potomac River. An older Tertiary upper-level terrace (Ttu) is present on a highly elevated flat bench east of Rock Creek Park near Walter Reed Army Medical Center (fig 2 and fig 4, Ttu). There also are at least three lower-level terraces $(\mathrm{Tt})$ in the area (fig. 2, Tt): a high terrace that underlies the area of the Carter Barron Amphitheater; an intermediate-level terrace that underlies the broad area opposite the National Zoo, and a low-level terrace that is incised into the intermediate terrace south of the zoo. These terraces probably range from middle Miocene ( 13.5 Ma) to late Pliocene (2.5 to $1.8 \mathrm{Ma})$ in age on the basis of pollen and stratigraphic correlation (McCartan, 1989). Colluvium (Qc), derived from Tertiary deposits on the uplands, forms drapes of cobbles on the slopes near Woodley Park just west of the National Zoo (fig. 2, Qc). Fleming and others (1994) interpreted the deposits to be Tertiary in age. Southworth and Denenny (2006) indicated that the colluvium has probably been accumulating since then.

To further add to the complexity of surficial sediments in Washington, D.C., both the lower Anacostia River and Rock Creek watersheds have undergone more than 200 years 

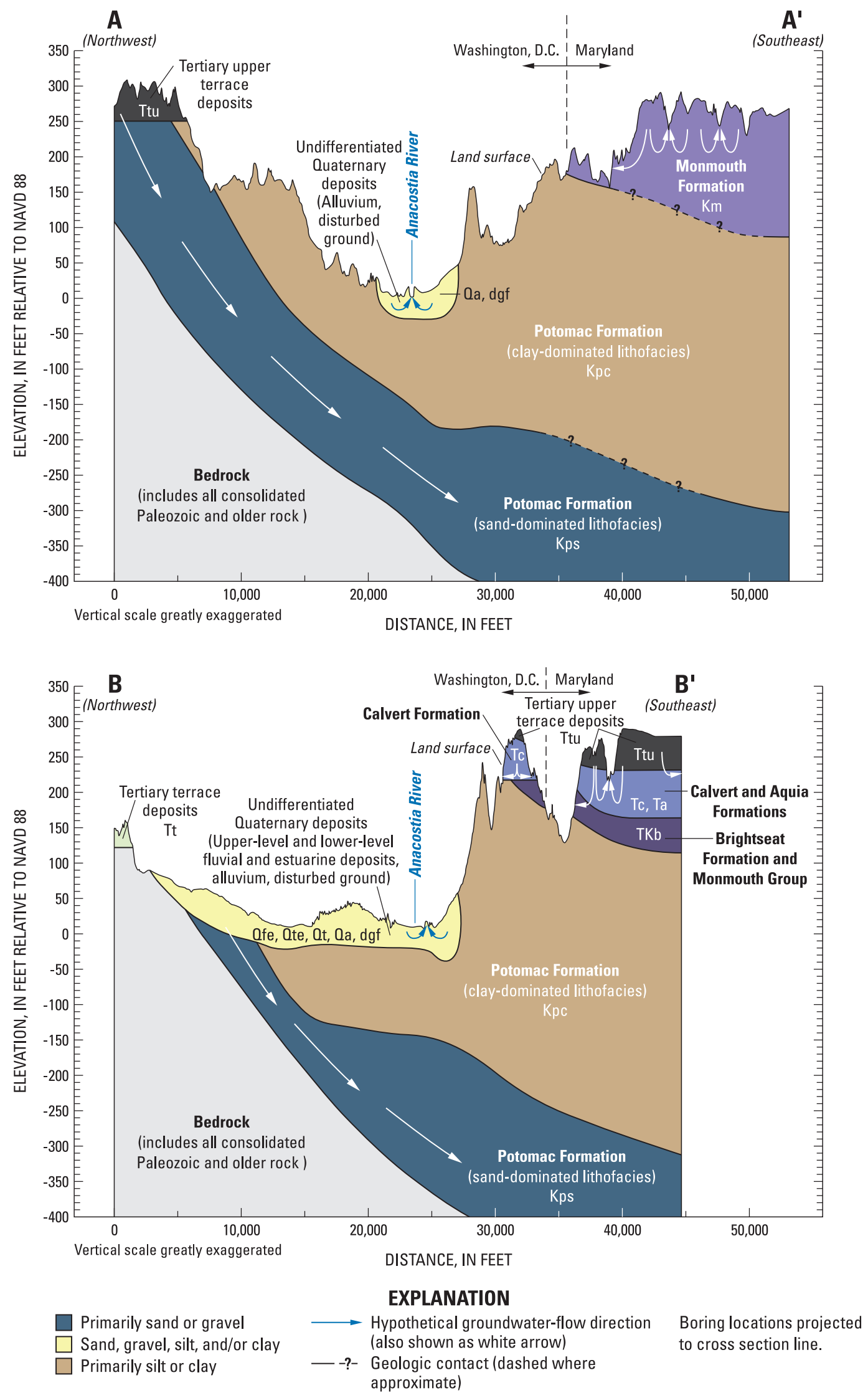

Figure 3. Generalized hydrogeologic cross sections A-A' and B-B' of the lower Anacostia River watershed, Washington, D.C. (S.W. Ator, U.S. Geological Survey, written commun., 2010). [Refer to figure 2 for location of cross sections and geologic units.] 


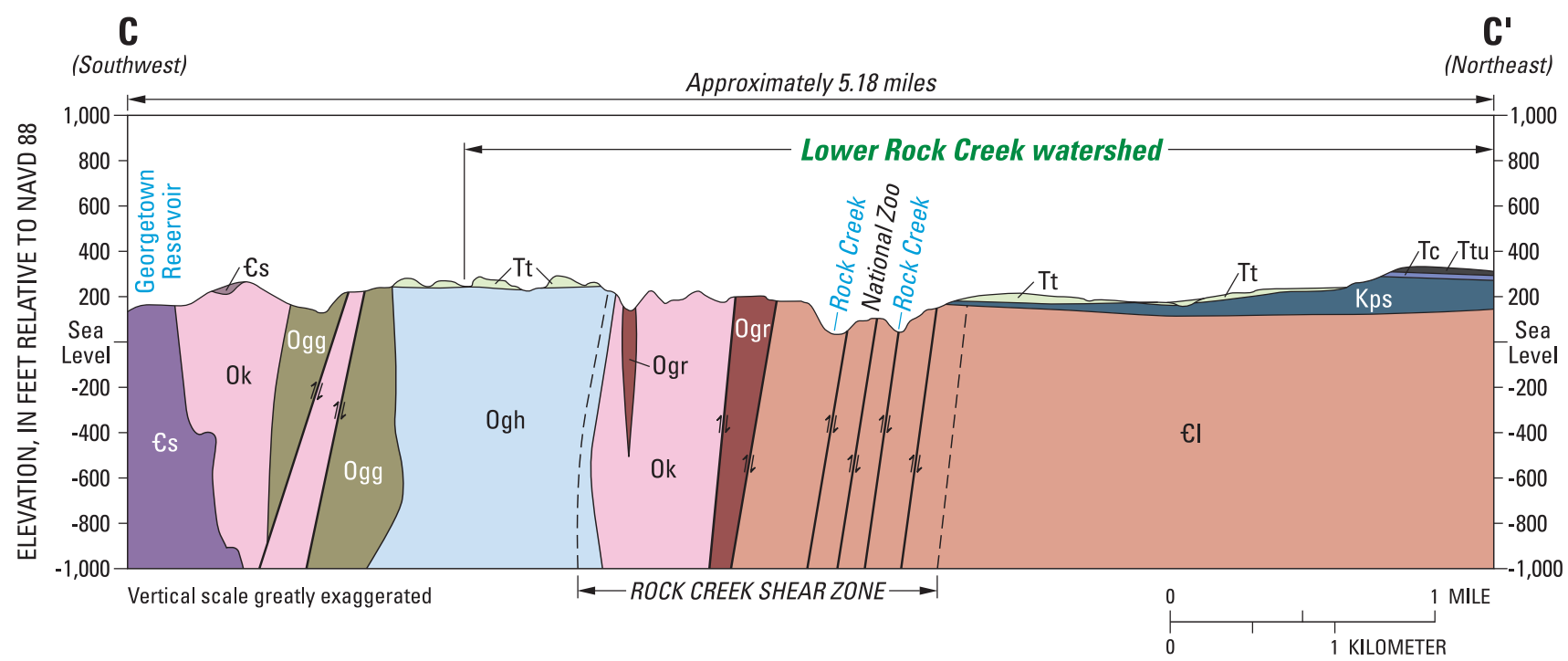

EXPLANATION

\begin{tabular}{|c|c|}
\hline $\mathrm{Tt}$ & Terrace deposits (Tertiary) \\
\hline Ttu & Highest level upland terrace deposits (Tertiar \\
\hline Tc & Calvert Formation (Middle Miocene) \\
\hline Kps & $\begin{array}{l}\text { Potomac Formation (Lower Cretaceous) } \\
\text { Sand-dominated lithofacies }\end{array}$ \\
\hline
\end{tabular}

CENOZOIC AND CRETACEOUS COASTAL PLAIN DEPOSITS

and-dominated lithofacies

\section{PALEOZOIC ROCKS (BEDROCK)}

Ok Kensington Tonalite (Middle Ordovician) Georgetown Intrusive Suite (Early Ordovician)

\begin{tabular}{|c|l}
\hline Ogh & Biotite-hornblende tonalite \\
\hline \hline $0 \mathrm{gg}$ & Quartz gabbro \\
\hline $\mathrm{Ogr}$ & Garnetiferous biotite-hornblende tonalite \\
\hline $\mathrm{Es}$ & $\begin{array}{l}\text { Sykesville Formation (Lower Cambrian) } \\
\text { Diamictite }\end{array}$ \\
\hline
\end{tabular}

$€ I$ Laurel Formation (Lower Cambrian)

$\longrightarrow$ Geologic contact (dashed where concealed) $\quad \rightleftarrows$ Fault

Figure 4. Generalized geologic cross section C-C' of surficial geology of the lower Rock Creek watershed, which includes the Rock Creek shear zone, Washington, D.C. (modified from Southworth and Denenny, 2006). [Line of section is shown in figure 2.]

of development. In the case of the Anacostia watershed, the stream was subjected to major sedimentation as the watershed cover changed from forest to agriculture, then from agriculture to urban and suburban land uses. Williams (1977) noted that the Anacostia River was navigable north of Washington, D.C. up until the early 1880 s. Heavy sedimentation occurred in the river bottom and along streambanks throughout most of the watershed as a result of agricultural, then urban, development in the 19th and 20th centuries. Tenbus (2003) described various topographic maps and sediment cores collected along the river, which illustrate that considerable fill was deposited in wetlands and low-lying areas along streambanks as a result of development or dredging. Cut-and-fill operations likely have occurred in many other parts of the Anacostia River watershed. Johnston (1964) indicated that as late as the mid20th century, considerable suburban development occurred in Washington, D.C. and surrounding areas. Thus, there likely are widespread occurrences of fill and disturbed landscapes throughout the Anacostia River watershed outside the naturalarea parks, with only the largest areas of fill (dgf) appearing on Washington, D.C.-scale geologic maps (fig. 2).

In the case of the Rock Creek watershed, only about 30 percent of the watershed lies within Washington, D.C. (fig. 1). With the exception of Rock Creek Park, which is up to a $\mathrm{mi}$ (mile) wide and runs about $9.3 \mathrm{mi}$ from the northern to southern boundaries of Washington, D.C., much of the Rock Creek watershed within Washington, D.C. is urban with commercial and residential developments (Anderson and others, 2002). Established in 1890, the park itself has not been highly disturbed. Historical development within Washington, D.C. outside the park, however, likely has led to considerable cutting and filling in of the original landscape, including many small first-order upland and headland streams beyond the boundaries of Rock Creek Park. As in the case of the Anacostia River watershed, only the largest areas of such fill appear on Washington, D.C.-scale geologic maps (fig. 2, dgf). 


\section{Groundwater Chemistry}

Some recent data exist to describe groundwater in the Anacostia River watershed, but there is little current (2008) or recent information on the quality of groundwater in the Rock Creek watershed.

Recharge differs among the major geologic formations in the Anacostia River watershed (S.W. Ator, U.S. Geological Survey, written commun., 2010). On the basis of groundwaterlevel contouring, Ator showed that groundwater flow in the unconfined aquifer generally is from upland recharge areas toward discharge areas along the Anacostia River and its tributaries (fig. 5). His analyses of hydraulic gradients illustrate that recharge to the confined Potomac aquifer occurs chiefly in the outcrop areas (for example, see fig. 3, sections A-A' and B-B'). Recharge to the unconfined aquifer chiefly is the result of infiltration in areas with permeable surficial sediments. In both cases, the quality of infiltrated water in this urban setting can reflect not only natural precipitation but anthropogenic activities and structures, such as irrigation of landscapes and leakage from water-supply, storm, and sewer lines.

An upward hydraulic gradient appears to occur beneath the Anacostia River (for example, see fig. 3 section B-B'; S.W. Ator, U.S. Geological Survey, written commun., 2010). Depending upon the depth of incision of the river channel, this could enhance groundwater flow into the river from the surficial aquifer or, if the confining clay lithofacies are removed by river down-cutting, lead to groundwater flow into the river from what otherwise would be a confined Potomac Formation.

Groundwater in terrace and Potomac Formation materials in the Anacostia River watershed commonly is oxic, with low concentrations of iron, and elevated concentrations of selected compounds that generally are considered indicators of anthropogenic contamination (fig. 6; S.W. Ator, U.S. Geological Survey, written commun., 2010). The latter include:

a. Nitrate concentrations in excess of $10 \mathrm{mg} / \mathrm{L}$ in most groundwater samples taken from wells completed in this urban setting and these sediments; in contrast, nitrate concentrations in other Coastal Plain sites associated with forest or little human activity (for example, pastureland) are approximately $4 \mathrm{mg} / \mathrm{L}$ or less

(Hamilton and others, 1993);

b. Chloride concentrations in excess of $75 \mathrm{mg} / \mathrm{L}$ in most groundwater samples taken from wells completed in this urban setting and these sediments; in contrast, chloride concentrations in other Coastal Plain sites associated with undeveloped (for example, forest) or minimally developed (for example, pasture) lands are approximately $6 \mathrm{mg} / \mathrm{L}$ or less (Hamilton and others, 1993); and

c. Detectable and often quantifiably measureable concentrations of synthetic organic contaminants, such as volatile and semi-volatile organic compounds and pesticides in most groundwater samples taken from this urban setting and these sediments; in contrast, these compounds generally are undetected, or detected only at low concentrations (estimated with higher than normal uncertainty), in shallow groundwater in similar sediments underlying undeveloped or minimally developed landscapes (Hamilton and others, 1993).

Other indicators of anthropogenic activities appear to have affected groundwater, including oil and grease, petroleum hydrocarbons, and gasoline- and diesel-related organics (S.W. Ator, U.S. Geological Survey, written commun., 2010). The frequency and variety in the types of organic compounds detected in groundwater generally were greater in wells located in high-density developments (residential, commercial, or municipal), than in low-density residential neighborhoods or parks.

In the Rock Creek watershed, stream rather than groundwater quality has been the focus of recent studies (Anderson and others, 2002; Miller and others, 2007; Phelan and Miller, in press). These studies have shown that streamflow, including base flow in Rock Creek, contains elevated concentrations of nutrients and selected trace elements, and a variety of synthetic organic compounds including pesticides.

In relation to groundwater, Schneider and others (1993, Schneider, Montaser, and Watt, 1993) conducted two relatively targeted, local studies on the quality and chemistry of groundwater in the Rock Creek watershed in the 1990s. Johnston (1964) conducted the last large-scale assessment of shallow groundwater quality and chemistry in and near Washington D.C. that included the Piedmont setting. On the basis of limited historical data, he characterized natural groundwater as a calcium-bicarbonate water with soft-to-moderate hardness. Johnston (1964) noted that natural water-quality impairments for human use throughout Washington, D.C. and nearby areas were high iron concentrations (in excess of $0.3 \mathrm{mg} / \mathrm{L}$ ), and high corrositivity, defined as dissolved carbon dioxide in excess of $10 \mu \mathrm{g} / \mathrm{L}$. For example, he found that 40 percent of the wells that were analyzed for iron had iron concentrations in excess of $0.3 \mathrm{mg} / \mathrm{L}$.

\section{Data-Collection Methods and Data Quality}

Samples and measurements for water quality were collected at 24 wells in the Anacostia River and Rock Creek watersheds in Washington, D.C. in 2005 and 2008 for this study. One of these wells was located west of the Rock Creek watershed. In addition, quality-control samples and data were collected to help determine the accuracy and comparability of the groundwater data. 


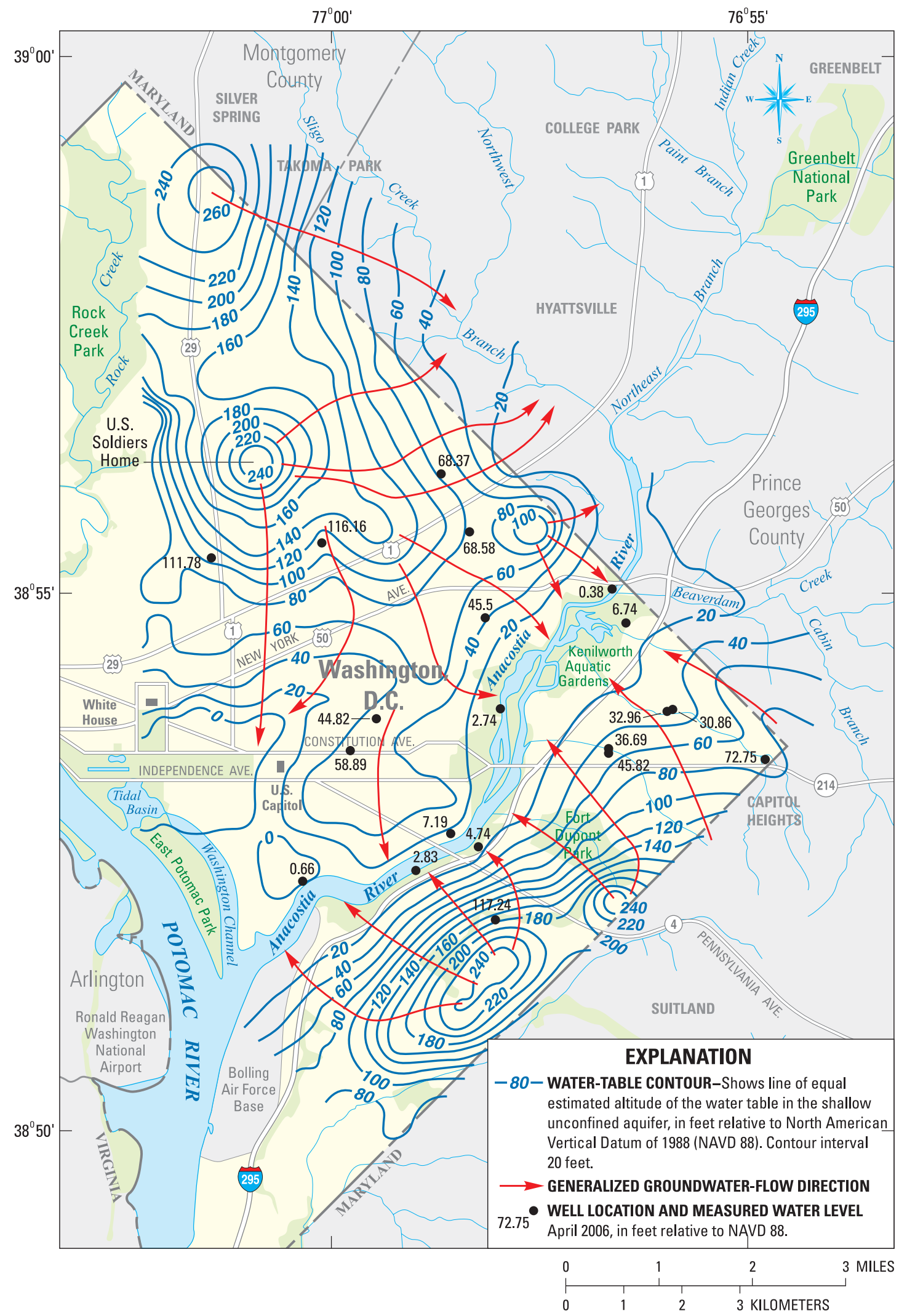

Figure 5. Estimated altitude of the regional water table and generalized direction of groundwater flow in the surficial aquifer, lower Anacostia River watershed, Washington, D.C., April 2006 (S.W. Ator, U.S. Geological Survey, written commun., 2010). 


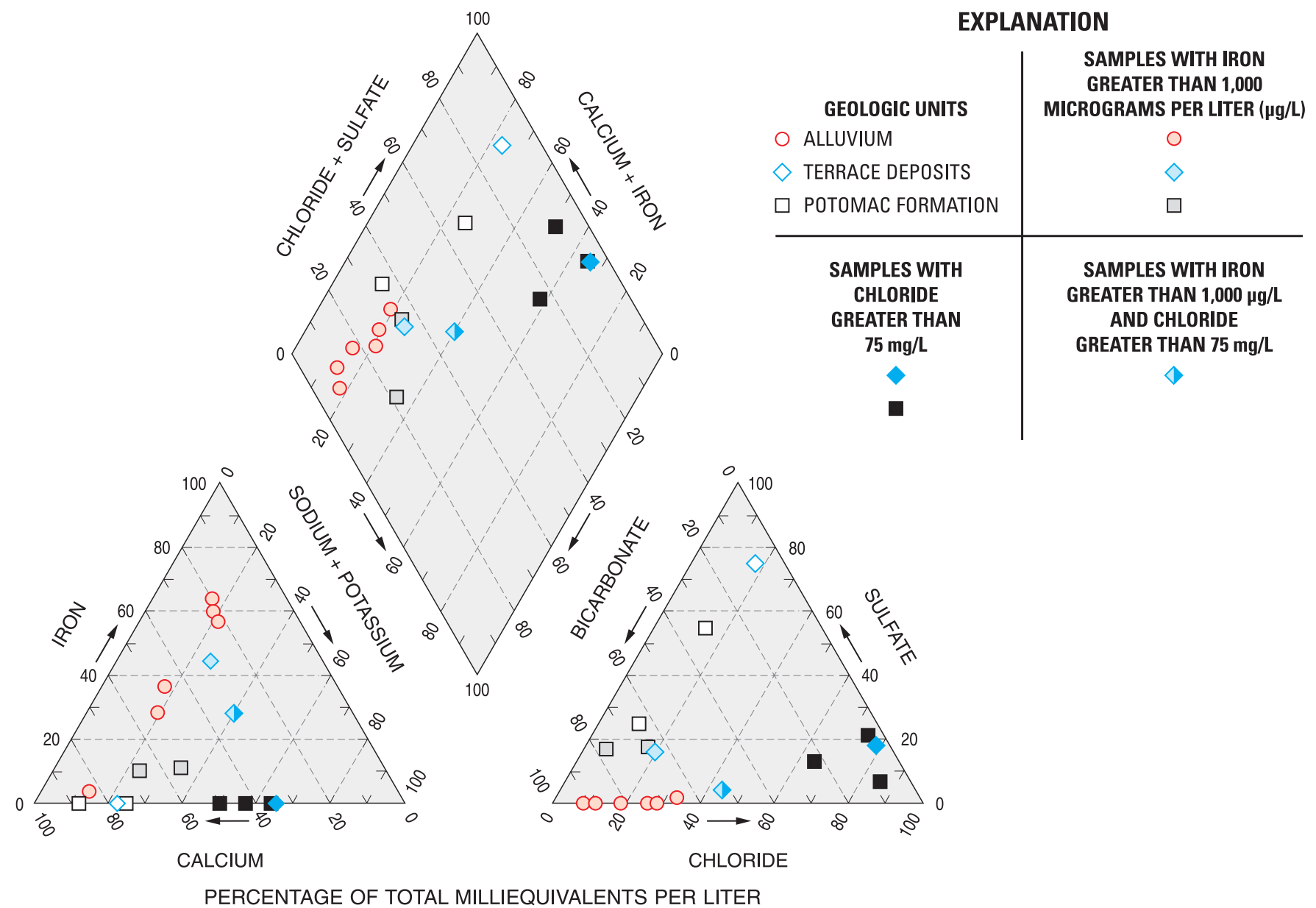

Figure 6. Trilinear diagrams showing major-ion chemistry of groundwater, by geologic unit, for the lower Anacostia River watershed, September to December 2005 (S.W. Ator, U.S. Geological Survey, written commun., 2010).

\section{Data-Collection Methods}

Previously installed monitoring wells (for example, from studies by Schneider and others, 1993 and 1993b) that could be located, that had reliable construction information, and that could be redeveloped and sampled, were included in this study. Additional wells were installed in locations that increased the spatial distribution of monitoring wells and in different geologic settings. Large open areas were required to provide access and lateral and vertical clearance for the drilling equipment and to avoid underground and overhead utilities. For these reasons, most monitoring wells were installed on either NPS property (in 2005 and 2008) or D.C. Parks and Recreation property (in 2005).

Inspection of previously installed wells and the installation of new wells by the USGS to meet DDOE recommendations are described by Miller and Klohe (2003), Tenbus (2003), Klohe and Debrewer (2007), and S.W. Ator (U.S. Geological Survey, written commun., 2010). In brief, most (20 of 24) wells were individually located at different sites (fig. 1 and table 1). At four sites, pairs of wells were installed at two different depths (table 1, shaded couplets). Most wells were installed in the surficial aquifer at shallow depths - less than $40 \mathrm{ft}$ below land surface. Five wells were completed at depths in excess of $40 \mathrm{ft}$ (table 1); these wells provided data from the deeper Piedmont bedrock or Potomac Group sediments. Information on the identification, construction, and location of wells was collected and compiled from well records or field inspections of the selected monitoring wells and from field observations and records obtained during the drilling and installation of new monitoring wells (table 1).

Field measurements of selected water-quality properties were taken during sampling each year, and included $\mathrm{pH}$, temperature, turbidity, specific conductance, and the concentration of dissolved oxygen. In addition, quality-control (QC) samples, including field blanks and duplicate sequential groundwater samples, were collected at each of two different wells during each year of data collection.

Sample collection and processing were similar in both years of data collection and have been described in Klohe and Debrewer (2007). In brief, groundwater samples were collected from each well with a peristaltic or stainless steel 
pump after the well was purged of generally a minimum of three well volumes to remove water that had been standing in the casing. Samples for the analysis of dissolved inorganic constituents were filtered during collection through an encapsulated, $0.45-\mu \mathrm{m}$ (micrometer)-effective-pore-size, pleated, cellulose nitrate filter, and samples for dissolved organic constituents, including pesticides, were filtered through a 0.70 - $\mu \mathrm{m}$-effective-pore-size, 142 -millimeter-diameter baked, glass-fiber, plate filter.

All 2005 groundwater and QC samples were analyzed by the USGS National Water Quality Laboratory (NWQL) in Denver, Colorado, or by the USGS-certified Severn Trent Laboratory in Arvada, Colorado. Samples were analyzed for selected pesticides (78 chiefly nonpolar parent or degradate compounds), major ions, nutrients, and other selected chemical constituents whose occurrence or concentrations could be related to natural processes and human activities in the study area. All 2005 groundwater and QC data have been published (Klohe and Debrewer, 2007, appendixes).

Samples collected in 2008 (table 1) from seven of the same wells used in 2005, and seven additional wells not used for data-collection in 2005, were analyzed by the NWQL or the USGS Organic Chemistry Research Laboratory in Lawrence, Kansas. Samples were analyzed for selected pesticides (over 150 parent or degradate compounds), major ions, and nutrients. All 2008 groundwater and QC data are provided in this report (appendix A).

\section{Data Quality}

An evaluation of the quality of the data collected in 2005 and 2008 was made on the basis of QC data obtained from field blanks and duplicate sequential groundwater samples, from USGS laboratory surrogate recoveries collected during the analysis of groundwater samples, and from groundwater samples taken from the same seven wells for both years of data collection (appendix B). The purpose of this evaluation was twofold: to assess the quality of the groundwater data collected in 2005 and in 2008, and to assess whether data from both years could be combined for selected interpretive analysis. The results of this evaluation are summarized below:

a. For both years, and except for trace amounts of selected major ions, the concentrations of all groundwater constituents, including all pesticides, in fieldblank samples were below the Laboratory Reporting Levels (LRLs). In addition, no pesticide was detected in any field blank. Also, the magnitude of the concentrations of constituents found in groundwater samples exceeded the magnitude of any trace amounts of those constituents found in the field blanks. Thus, no appreciable bias due to contamination appears to have been introduced during the collection, processing, preservation, shipping, or analysis of groundwater samples in either year of data collection that could limit the interpretation of the pesticide and other water-quality data. b. For both years, data obtained from sequential duplicate groundwater samples collected at selected wells revealed similar precision results - low variability between measurements of duplicate samples for most constituents, including pesticides. For inorganic constituents with measureable concentrations, the relative difference between concentrations in duplicate samples for most inorganic constituents typically was no more than approximately 10 to 12 percent, and usually less than 1 percent. For organic constituents and, in particular, for pesticides, the relative difference between concentrations in duplicate samples was generally 20 percent or less, and for most of the constituents, less than 1 percent.

c. The differences in the type and number of pesticide detections in 2005 and 2008 groundwater samples, in part, could be due to differences in the number and performance of laboratory analytical methods used. In 2008, an additional pesticide method was used that resulted in detections of pesticides (15) in 2008 samples that were not detected in 2005 samples collected from the same wells. In addition, the performance of one USGS NWQL laboratory method varied between years in a manner that appears to have led to more pesticides detected in 2008 samples than were detected in 2005 samples collected from the same wells.

Given (a) and (b) above, the data collected within a given year were considered suitable for interpretation. Similarities in the quality of data collected for both years indicated that data possibly could be combined from both years for the purposes of interpretation.

Given (c) above, pesticide detections in 2005 and 2008 appeared to differ at least in part because of differences in the number and performance of the laboratory analytical methods used in 2005 and 2008. In addition, only 7 of the 17 wells sampled in 2005 were resampled in 2008. For these reasons, the interpretations of the pesticide data are constrained in this study. As an example, although temporal variation in hydrologic conditions could play a role in the differences in pesticide detections in 2005 and 2008, one cannot discount that the differences in pesticide detections between these years could simply reflect differences in the number and performance of laboratory methods. The constraints on interpretations of the pesticide data in this study affect the approaches used to (a) describe the occurrence and distribution of pesticides, and (b) assess pesticide occurrence in groundwater in relation to selected land-use and hydrogeologic characteristics, in the surficial aquifer.

Interpretations in this report chiefly were conducted using either the 2008 or the 2005 data, with an emphasis on the pesticide data collected in 2008 . The 2008 data provide the most widespread and complete indication of pesticides in the shallow groundwater in both the Anacostia River and Rock Creek watersheds and the most diversity in geologic settings. Combined data from both years are used in some 


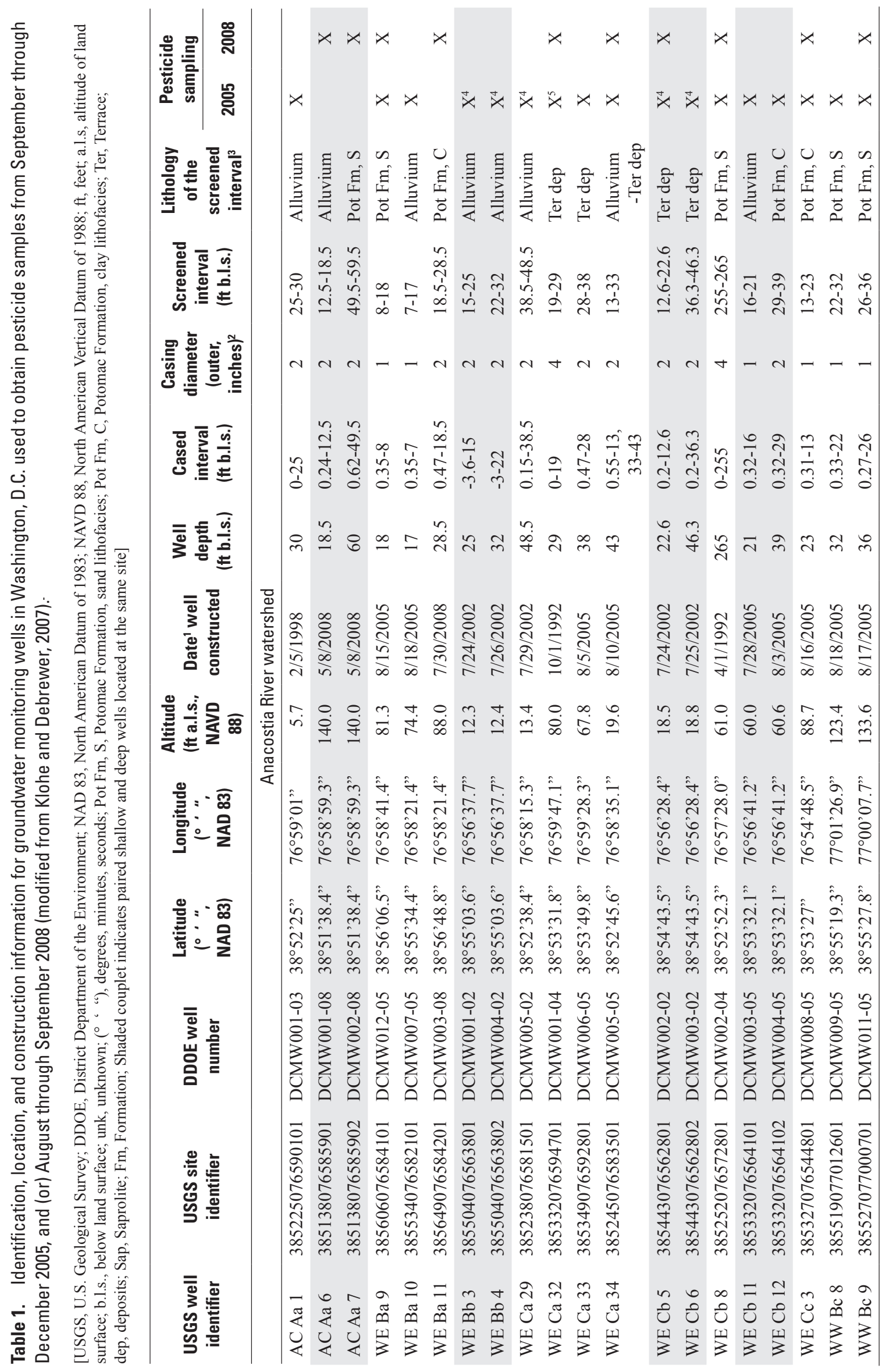




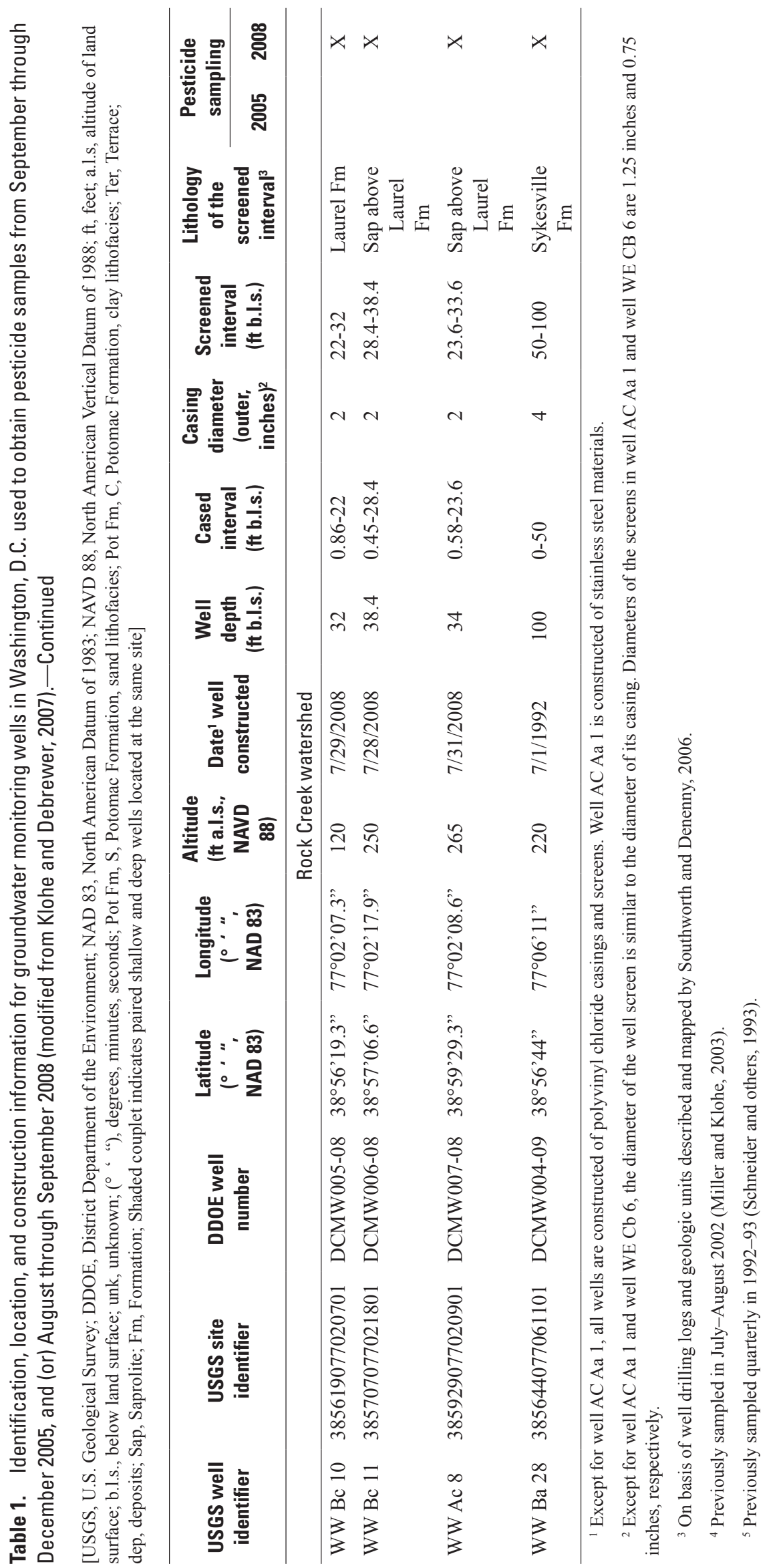


circumstances, for example, to describe the general types and concentrations of pesticides found and to identify potential relations (future testable hypotheses) between pesticide occurrence in groundwater and selected surficial and subsurface characteristics in the study area. The interpretive results in each case of combined data use, however, are qualified to the extent possible in terms of limitations in the data.

\section{Pesticides in Groundwater}

Pesticides present in shallow groundwater can be described in relation to their types and frequencies of detection on the basis of the data obtained from the wells used for data collection in 2005 and 2008 (fig. 1). The concentrations of detected pesticides in shallow groundwater also can be assessed in relation to human- and aquatic-health criteria and guidelines.

\section{Pesticide Types and Frequencies of Detection}

Summary data from all sampling sites and, in the case of the paired-well sites, from just the shallowest well at each location, indicate that 27 different pesticides (parent or degradate compounds) were detected in groundwater samples collected in 2005 and 2008 (table 2). The detected compounds reflect at least 19 unique herbicides or insecticides - distinct parent compounds, or degradate compounds that can be associated with distinct parent compounds. Although analyses for fungicides were included, no fungicides were detected. Fungicides in laboratory analysis of groundwater samples included benomyl, metalaxy, and propiconazole.

The detected herbicides chiefly reflect compounds used for non-specific weed (broadleaf or grass) control, and the detected insecticides chiefly reflect compounds used for noncrop haustellate (sucking) insects or termite control (table 2). In addition, the detected compounds reflect parent or degradate pesticides (a) generally still in use, but perhaps currently at more restricted levels, for example, $s$-triazines; (b) wholly or highly restricted in use, for example, DDT, chlordane, heptachlor, and dieldrin; or (c) whose use was designed to replace banned pesticides, for example, fipronil, in place of dieldrin, chlordane, and heptachlor. The presence of pesticide parent or degradate compounds banned from further use (DDT and chlordane) illustrates their continued persistence and resistance to decomposition in the environment, possibly decades after their use was discontinued. Also the presence of replacement pesticides such as fipronil, which was developed in part to replace the discontinued termitic pesticides, indicates the permeable nature of the surficial aquifer in Washington, D.C. and its vulnerability to continued contamination by recently introduced pesticides.

For those pesticides for which analyses for degradates were conducted, it is apparent that degradate compounds were as likely, or more likely, to be detected than parent compounds (table 2, $s$-triazines, glyphosate, DDT, heptachlor, and fipronil). This finding highlights the importance of analyzing for degradate as well as parent pesticide compounds to accurately determine overall occurrence in groundwater. Recent studies of the surficial aquifer in the Coastal Plain and Piedmont Provinces near Washington, D.C. indicate that multiple degradates of these and other compounds are more likely to be detected in groundwater than the parent compounds (Denver and Ator, 2006; Banks and Reyes, 2009).

Different types of pesticides were detected at different frequencies in shallow groundwater in the study area (table 2). Herbicides were detected more frequently than insecticides. In 2005 and 2008, one or more herbicides were detected in shallow groundwater at 43 and 62 percent of the study sites, respectively. At each well-pair location, the deepest well contained no detectable pesticides. Therefore, frequencies of detection by well location were computed on the basis of the shallow well at each of these locations. In contrast, one or more insecticides were detected in shallow groundwater at only 29 and 38 percent of the study sites in 2005 and 2008, respectively.

Although fewer types and numbers of herbicides were detected in shallow groundwater in 2005 than in 2008 (table 2), the most frequently detected herbicides in 2005 were the $s$-triazines and $s$-triazine degradates, and the ureic herbicides. In each case, one or more parent and (or) degradate compounds for each type of herbicide were found in shallow groundwater at 21 percent of the study sites. No laboratory analysis was conducted for alachlor and metolachlor in 2005.

The most frequently detected type of herbicides in shallow groundwater in 2008 were the $s$-triazine compounds -atrazine, simazine, prometon, and the atrazine-degradate compounds, CIAT and OIET; one or more of these compounds were detected in shallow groundwater at 62 percent of the study sites. The next most frequently detected herbicides in 2008 were chlorinated acetanilides, acetachlor and metolachlor, with one or both detected at 29 percent of the study sites, and the ureic herbicides (diuron, fluometuron, metsulfuron methyl, sulfameturon methyl, bromacil, and tebuthiuron), with one or more of these compounds also detected at 29 percent of the study sites. The least frequently detected type of herbicide was an organophosphate compound - glyphosate and its degradate, amino-methyl-phosphonic acid (AMPA); each of these compounds was detected once at different sites.

Although detections of herbicides differed by type, there was no marked difference in the frequency with which different types of insecticides were detected in shallow groundwater (table 2). Detections, however, could reflect resistance to degradation across general insecticide types.

Few insecticides were detected in shallow groundwater in 2005 , and as in 2008 , detections chiefly reflected insecticides resistant to degradation. Detections consisted of one or two detections of five different types of insecticides or insecticide degradates - p,p'-DDE, dieldrin, heptachlor epoxide, chlordane, and imidacloprid. 
Table 2. Detected pesticide compounds by type and use, detection frequency using either only or shallowest well at each site, maximum concentration, and related human- and aquatic-health concentration criteria and guidelines, for groundwater in Washington, D.C., 2005 and 2008.

[n/a, not analyzed; E, quantified above the long-term method detection limit but below the laboratory reporting level with higher uncertainty; M, present, but not quantified; $\mu \mathrm{g} / \mathrm{L}$, micrograms per liter; ---, no recommended or established standard; $\mathrm{P}$, pending; <, less than]

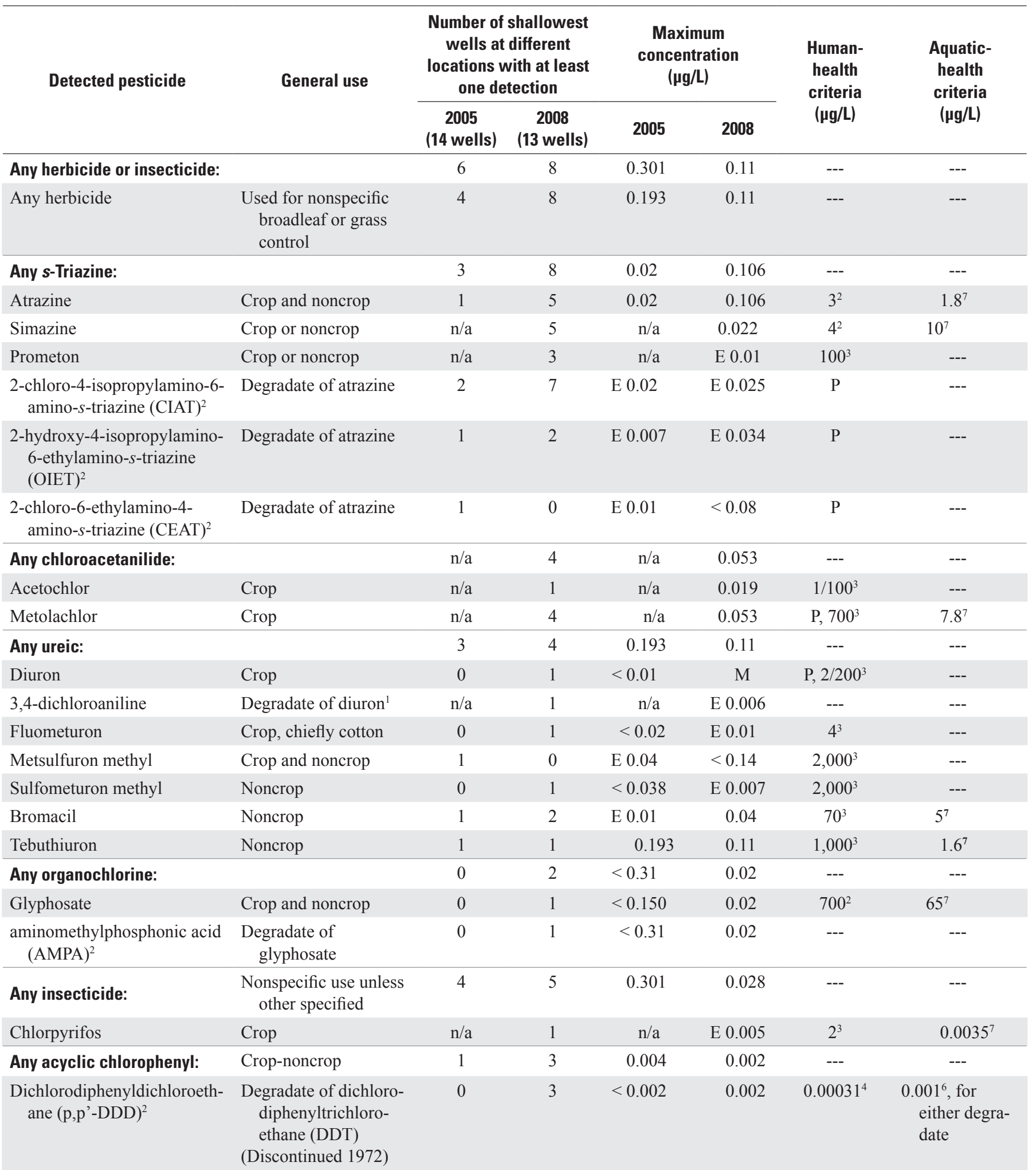


Table 2. Detected pesticide compounds by type and use, detection frequency using either only or shallowest well at each site, maximum concentration, and related human- and aquatic-health concentration criteria and guidelines, for groundwater in Washington, D.C., 2005 and 2008. - Continued

[n/a, not analyzed; E, quantified above the long-term method detection limit but below the laboratory reporting level with higher uncertainty; M, present, but not quantified; $\mu \mathrm{g} / \mathrm{L}$, micrograms per liter; ---, no recommended or established standard; P, pending; <, less than]

\begin{tabular}{|c|c|c|c|c|c|c|c|}
\hline \multirow[t]{2}{*}{ Detected pesticide } & \multirow[t]{2}{*}{ General use } & \multicolumn{2}{|c|}{$\begin{array}{l}\text { Number of shallowest } \\
\text { wells at different } \\
\text { locations with at least } \\
\text { one detection }\end{array}$} & \multicolumn{2}{|c|}{$\begin{array}{c}\text { Maximum } \\
\text { concentration } \\
(\mu \mathrm{g} / \mathrm{L})\end{array}$} & \multirow{2}{*}{$\begin{array}{c}\text { Human- } \\
\text { health } \\
\text { criteria } \\
(\mu \mathrm{g} / \mathrm{L})\end{array}$} & \multirow{2}{*}{$\begin{array}{l}\text { Aquatic- } \\
\text { health } \\
\text { criteria } \\
\text { ( } \mu \mathrm{g} / \mathrm{L} \text { ) }\end{array}$} \\
\hline & & $\begin{array}{c}2005 \\
\text { (14 wells) }\end{array}$ & $\begin{array}{c}2008 \\
\text { (13 wells) }\end{array}$ & 2005 & 2008 & & \\
\hline $\begin{array}{l}\text { Dichlorodiphenyldichloroeth- } \\
\text { ylene (p,p'-DDE) }\end{array}$ & $\begin{array}{l}\text { Degradate of DDT } \\
\text { (Discontinued 1972) }\end{array}$ & 1 & 0 & 0.004 & $<0.002$ & $\mathrm{P} ; 0.00021^{4}$ & $\begin{array}{l}0.003^{6} \text {, for DDT } \\
\text { plus degra- } \\
\text { dates }\end{array}$ \\
\hline Dieldrin & Crop-noncrop & 2 & 3 & 0.065 & 0.028 & $\begin{array}{l}0.002 / 0.2^{3} \\
0.000052^{4}\end{array}$ & $\begin{array}{l}0.056 / 0.0019^{5} \\
0.001^{6}\end{array}$ \\
\hline Imidacloprid & Crop, sucking insects & 1 & 0 & 0.301 & $<0.060$ & $400^{3}$ & --- \\
\hline Any chlorinated cyclodiene: & $\begin{array}{l}\text { Crop-noncrop } \\
\quad \text { (termites) }\end{array}$ & 2 & 3 & E 0.1 & 0.021 & --- & -- \\
\hline Any phenopyrazole: & $\begin{array}{l}\text { Noncrop, termites and } \\
\text { pet pests }\end{array}$ & $\mathrm{n} / \mathrm{a}$ & 2 & $\mathrm{n} / \mathrm{a}$ & E 0.009 & --- & --- \\
\hline Fipronil & & $\mathrm{n} / \mathrm{a}$ & 2 & $\mathrm{n} / \mathrm{a}$ & E 0.009 & --- & --- \\
\hline Fipronil sulfide & Degradate of fipronil & $\mathrm{n} / \mathrm{a}$ & 2 & $\mathrm{n} / \mathrm{a}$ & E 0.007 & --- & --- \\
\hline Fipronil sulfone & Degradate of fipronil & $\mathrm{n} / \mathrm{a}$ & 1 & $\mathrm{n} / \mathrm{a}$ & E 0.005 & --- & --- \\
\hline
\end{tabular}

${ }^{1}$ Dichloroaniline is a possible degradate of diuron, linuron, neburon, swep (methyl-N(3,4-diphenyl) carbamate), chlorpyrifos, and propanil

(J.E. Barbash, U.S. Geological Survey, written commun., 2009); only diuron was detected in the sample with 3,4 dichloroaniline.

${ }^{2}$ U.S. Environmental Protection Agency (USEPA) Maximum Contaminant and Health Advisory Levels for drinking water (U.S. Environmental Protection Agency, 2004).

${ }^{3}$ U.S. Geological Survey, Health Based Assessment Benchmark (Toccalino, 2007), low/high values or single value for both.

${ }^{4}$ USEPA recommended human-health criteria for consumption of water and organisms (U.S. Environmental Protection Agency, 1999); and P, USEPA pending candidate on drinking-water contaminant list (U.S. Environmental Protection Agency, 2005).

${ }^{5}$ USEPA national recommended long-term aquatic chronic-exposure criteria for continuous concentration for freshwater/saltwater (U.S. Environmental Protection Agency,1999).

${ }^{6}$ Great Lakes aquatic-health objectives (International Joint Commission, 1989).

${ }^{7}$ Canadian Council of Ministers of the Environment guidelines for the protection of aquatic health (Canadian Council of Ministers of the Environment, 2007). 
The most frequently detected insecticides in 2008 were p,p'-DDD, dieldrin, and heptachlor epoxide (a degradate of heptachlor); each pesticide was detected at 23 percent of the study sites, but not necessarily the same sites. Use of all three of these insecticides has been completely or highly restricted for decades (table 2). In addition to the resistant insecticides, fipronil and one or both fipronil degradates were detected in shallow groundwater at 15 percent of the study sites, and chlorpyrifos was detected at one study site.

Comparison of the pesticide data collected in 2008 with the data collected in 2005 indicates that groundwater samples in 2008 contained considerably more types of pesticides and had higher frequencies of detections by pesticide type than groundwater samples collected in 2005 (table 2). In addition, except for four pesticide compounds, most pesticides detected in shallow groundwater samples collected in 2005 were again detected in groundwater samples collected from those same wells in 2008. The four exceptions are the single-occurrence detections in 2005 of the herbicides 2-chloro-6-ethylamino-4amino-s-atrazine (desisopropylatrazine or CEAT), metsulfuron methyl, glyphosate, and a degradate of the insecticide DDT, $\mathrm{p}, \mathrm{p}$ '-DDE.

\section{Pesticide Concentrations and Human- and Aquatic-Health Criteria and Guidelines}

Concentrations of pesticides in shallow groundwater samples obtained in either 2005 or 2008 were quite low. Maximum concentrations for all parent or degradate compounds were no greater than a few tenths of a microgram per liter and often were less than $0.1 \mu \mathrm{g} / \mathrm{L}$ (table 2 ). In particular, many residue concentrations were less than the LRL of the analytical method (appendix A, table A1), which implies a higher than normal uncertainty in the measured concentrations.

In relation to human-health criteria, summary data indicate that no pesticide covered by Federal drinking-water standards for public supplies was found at concentrations in shallow groundwater that exceeded the USEPA Maximum Contaminant Level (MCL) for drinking water (table 2). Absent USEPA MCL criteria, human-health standards other than the USEPA MCL have been considered for groundwater, including the USEPA recommended human-health criteria for consumption of water (U.S. Environmental Protection Agency, 1999) and the USEPA-approved non-regulatory USGS health-based assessment benchmarks (Banks and Reyes, 2009; Toccalino, 2007; Denver and Ator, 2006; Toccalino and others, 2004). Groundwater data obtained from monitoring wells in the surficial aquifer in Washington, D.C. do not directly reflect water that is consumed, and therefore, are not directly relevant to human health. Nevertheless, DDOE protects the shallow groundwater as if it were a drinking-water source. Embassies and other government buildings often have wells as back-up water supplies, which could potentially be used as drinking water. Furthermore, the contamination of groundwater in the surficial aquifer in this study, as in other studies where these criteria have been applied, may indicate potential for future contamination in deeper aquifers and in base flows to surface water, both of which are used for drinking-water supplies in Washington D.C. or nearby areas.

Application of human-health criteria and guidelines to the pesticides present in shallow groundwater in this study indicates that concentrations of p,p'-DDD, p,p'-DDE, dieldrin, chlordane, and heptachlor epoxide did exceed the USEPA national recommendations for the consumption of water for these compounds (table 3, human-health assessment). Dieldrin concentrations in groundwater samples from three wellsWE Ca $32(0.028 \mu \mathrm{g} / \mathrm{L})$, WE Ba $11(0.016 \mu \mathrm{g} / \mathrm{L})$, and WW Ac $8(0.014 \mu \mathrm{g} / \mathrm{L})$ - in 2008, and two paired wells - WE Ca $32(0.065 \mu \mathrm{g} / \mathrm{L})$ and WE Ca $33(0.002 \mu \mathrm{g} / \mathrm{L})$ - in 2005, fell within the range of concern denoted by the non-regulatory USGS health-based assessment criterion for this compound (table 3, human-health assessment, dieldrin, $0.002 \mu \mathrm{g} / \mathrm{L}$ to $0.2 \mu \mathrm{g} / \mathrm{L})$. In particular, dieldrin also has been identified as a pesticide of concern on the basis of the USGS health-based assessment benchmark for shallow groundwater in other areas of the Coastal Plain and Piedmont Provinces near Washington, D.C. (Denver and Ator, 2006; Banks and Reyes, 2009).

Pesticide concentrations in shallow groundwater in 2005 and 2008 were compared to several available aquatic-health criteria and guidelines for freshwater (tables 2 and 3 ) including (a) the USEPA criteria for long-term chronic-exposure to continuous concentration (U.S. Environmental Protection Agency, 1999), (b) the 1989 U.S. and Canada International Joint Commission Great Lakes aquatic-health objectives, and (c) the 2007 Canadian Council Ministers of the Environment (CCME) guidelines for the protection of aquatic health. Although these aquatic-health criteria and guidelines chiefly were designed for constituents in surface water, their use in relation to groundwater in this study may be warranted because the shallow surficial aquifer likely is the chief source of water to local streams and wetlands in Washington, D.C.

The assessment of aquatic health demonstrated that refractory legacy compounds chiefly were responsible for most exceedances of aquatic-health criteria and guidelines (table 3). The 2005 concentrations of p,p'-DDE (one site), dieldrin (one site), and chlordane (one site) and the 2008 concentrations of heptachlor epoxide (three sites) and p,p'-DDD (three sites) exceeded the USEPA long-term chronic exposure concentrations for each of these compounds. In addition, the concentrations of dieldrin at three sites in 2008 and two sites in 2005, and of p,p'-DDE at one site in 2005, exceeded the U.S. Great Lakes aquatic-health criteria for each of these compounds. The concentration of chlorpyrifos at one site in 2008 also exceeded the Canadian aquatic-health guideline for this compound. Currently (2010), there are no drinking-water standards, other human-health criteria, or aquatic-health guidelines for the degradate compounds detected in shallow groundwater in this study (table 2). 
Table 3. Water-quality human- and aquatic-health assessment for groundwater samples collected from the surficial aquifer in Washington, D.C., 2005 and 2008.

$[\mu \mathrm{g} / \mathrm{L}$, micrograms per liter; E, quantified above the long-term method detection limit but below the laboratory reporting level with higher uncertainty; USEPA, U.S. Environmental Protection Agency; USGS, U.S. Geological Survey]

\begin{tabular}{|c|c|c|c|c|}
\hline Constituent & $\begin{array}{c}\text { USGS } \\
\text { well identifier }\end{array}$ & $\begin{array}{l}\text { Pesticide guidelines } \\
\text { or criteria } \\
\text { ( } \mu \mathrm{g} / \mathrm{L})\end{array}$ & $\begin{array}{l}\text { Pesticide sample } \\
\text { concentration } \\
(\mu \mathrm{g} / \mathrm{L})\end{array}$ & $\begin{array}{l}\text { Year of } \\
\text { collection }\end{array}$ \\
\hline \multicolumn{5}{|c|}{ Human-health assessment } \\
\hline \multicolumn{5}{|l|}{$\begin{array}{l}\text { USEPA recommended human-health criteria for } \\
\text { consumption of water }\end{array}$} \\
\hline \multirow[t]{3}{*}{ Dichlorodiphenyldichloroethane (p,p'-DDD) } & WE Ca 32 & 0.00031 & 0.002 & 2008 \\
\hline & WE Ba 11 & 0.00031 & E 0.001 & 2008 \\
\hline & WE $\mathrm{Cb} 8$ & 0.00031 & E 0.001 & 2008 \\
\hline Dichlorodiphenyldichloroethylene (p,p'-DDE) & WE Ba 9 & 0.00021 & 0.004 & 2005 \\
\hline \multirow[t]{3}{*}{ Dieldrin } & WE Ca 32 & 0.000052 & 0.028 & 2008 \\
\hline & WE Ba 11 & 0.000052 & 0.016 & 2008 \\
\hline & WW Ac 8 & 0.000052 & 0.014 & 2008 \\
\hline Chlordane & WE CA 32 & 0.00081 & E 0.1 & 2005 \\
\hline \multirow[t]{3}{*}{ Heptachlor epoxide } & WE Ca 32 & 0.000039 & 0.003 & 2008 \\
\hline & WE Ba 11 & 0.000039 & 0.021 & 2008 \\
\hline & WE Cb 8 & 0.000039 & 0.014 & 2008 \\
\hline \multicolumn{5}{|l|}{ USGS health-based assessment benchmark ${ }^{2}$} \\
\hline \multirow[t]{5}{*}{ Dieldrin } & WE Ca 32 & $0.002-0.2$ & 0.028 & 2008 \\
\hline & WE Ca 32 & $0.002-0.2$ & 0.065 & 2005 \\
\hline & WE Ba 11 & $0.002-0.2$ & 0.016 & 2008 \\
\hline & WE $\mathrm{Cb} 8$ & $0.002-0.2$ & 0.014 & 2008 \\
\hline & WE Ca 33 & $0.002-0.2$ & 0.002 & 2005 \\
\hline
\end{tabular}

There also are no human- and aquatic-health criteria or guidelines for the effects of mixtures of pesticides in groundwater. The data obtained in 2008 (appendix A, table A1) provide the most comprehensive assessment of pesticide mixtures in Washington, D.C. groundwater. As already noted (table 2), samples from 8 of the 13 wells completed in shallow groundwater had at least one detectable pesticide. Seven of these eight wells, or 88 percent, had five or more different pesticide compounds (appendix A, table A1). The highest number of detections occurred in the groundwater sample from well WE Ca 32, which contained 15 different pesticide compounds. The effects of such mixtures on human and aquatic health are relatively unknown.

\section{Comparison of Pesticides in Groundwater: Washington, D.C. and Nearby Coastal Plain and Piedmont Areas}

The occurrence of pesticides detected in shallow groundwater in Washington, D.C. is similar to patterns found for pesticides in shallow groundwater in nearby and similar Coastal Plain and Piedmont surficial aquifers. Denver and Ator (2006) described the occurrence of pesticides in the surficial aquifer in the Maryland Coastal Plain north and east of Washington, D.C. They identified parent or degradate compounds that represented at least 19 unique herbicides or insecticides in shallow groundwater. The concentrations of individual pesticide compounds generally were less than 
Table 3. Water-quality human- and aquatic-health assessment for groundwater samples collected from the surficial aquifer in Washington, D.C., 2005 and 2008.—Continued

$[\mu \mathrm{g} / \mathrm{L}$, micrograms per liter; E, quantified above the long-term method detection limit but below the laboratory reporting level with higher uncertainty; USEPA, U.S. Environmental Protection Agency; USGS, U.S. Geological Survey]

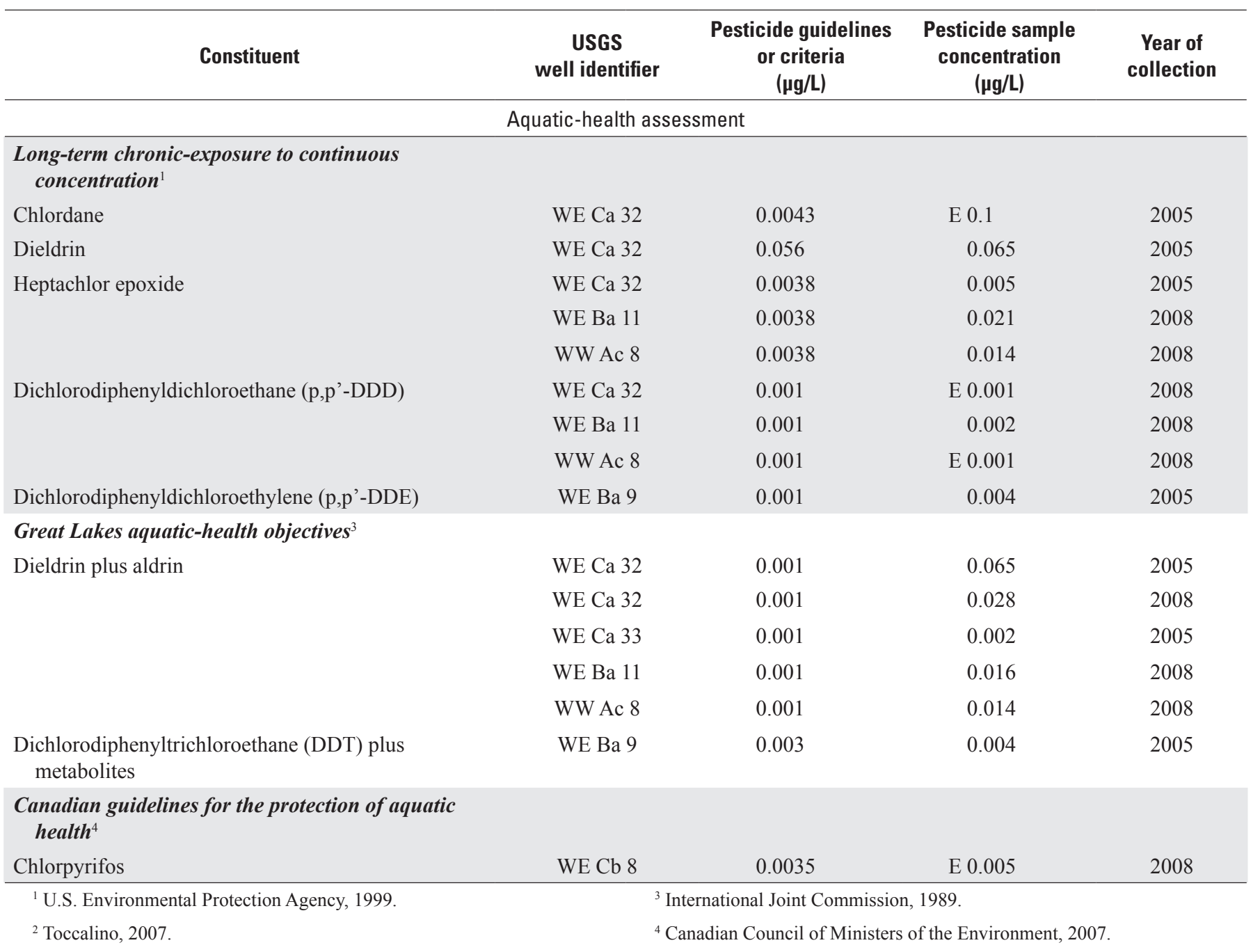

$0.1 \mu \mathrm{g} / \mathrm{L}$. More herbicides were detected than insecticides. The most commonly detected herbicides were atrazine, prometon, simazine, alachlor, metolachlor. and their multiple degradates. They found that herbicides, such as simazine, prometon, bromacil, and tebuthiuron, and the termitic insecticides, such as dieldrin, and selected degradates of these compounds, appeared most often in groundwater associated with urban settings. Denver and Ator (2006) described pesticide mixtures similar to those described for Washington, D.C. that occurred with a relatively high frequency. Groundwater samples from 68 percent of the wells used in their study contained at least one detectable pesticide. Groundwater samples from 94 percent of the wells that had detectable pesticides, however, contained more than one pesticide, and 53 percent of these wells yielded samples with at least five detectable compounds - chiefly s-triazines, acetanilides, and their degradates. Groundwater from one well contained eleven different pesticide compounds.

Banks and Reyes (2009) completed a groundwater study that involved 15 randomly selected community water-supply wells completed in the Piedmont bedrock in Maryland and Virginia and located in the lower Potomac River Basin near Washington, D.C. They identified 24 unique herbicides or insecticides. Concentrations of pesticides typically were less than $0.1 \mu \mathrm{g} / \mathrm{L}$. All 15 wells yielded the atrazine degradate CIAT. Seventy-three percent of the wells contained mixtures of five or more detectable pesticide residues - typically $s$-triazines, acetanilides, and their degradates. Groundwater obtained from one well contained 27 different pesticide and degradate compounds. 
The Anacostia River and Rock Creek derive their lowflow source waters at least in part from the surficial aquifer in the Coastal Plain and Piedmont within and outside of Washington, D.C. (fig.1). The combined results of this study with those from the studies by Denver and Ator (2006) and Banks and Reyes (2009) indicate that similar types, concentrations, and mixtures of pesticides are present in the surficial aquifer in Coastal Plain and Piedmont settings beneath these watersheds in and around Washington, D.C. Many of these detected pesticides reflect parent and degradate compounds that currently have no drinking-water or aquatic-health regulatory or non-regulatory standards, criteria, or guidelines, leaving the effects of these mixtures on human and aquatic health uncertain.

\section{Land Use and Hydrogeologic Factors Related to Pesticide Occurrence}

Land use (as a surrogate for pesticide use) and hydrogeologic characteristics, such as sediment permeability, have been shown to be related to the presence of pesticides in shallow groundwater. To assess whether or not such relations hold for the surficial aquifer in Washington, D.C., selected landscape and hydrogeologic characteristics associated with the wells used in this study were examined in relation to the pesticides present in shallow groundwater. The ability to conduct this evaluation, however, is at least partially limited because of the following two factors:

a. A possible bias exists in well locations toward open, accessible space and parks. Most wells that were sampled are located in open accessible space and few are in close proximity to locations in urban areas that generally would reflect high pesticide use on the basis of land use, such as highly developed residential, commercial, or other infrastructure. This bias could differ in relation to wells used for data collection in 2005 compared to those used in 2008. In 2005, wells were located chiefly in larger Federal or other parks in the lower Anacostia River watershed (fig.1). In 2008, seven of the wells used in 2005 were re-sampled, and seven additional wells were sampled that were located in smaller recreational parks or on relatively undeveloped open space in the lower Anacostia River watershed, Rock Creek watershed, or west of Rock Creek watershed (fig. 1).

b. Differences in the number of methods used to analyze for pesticides in groundwater and the performance of these methods could have resulted in more pesticides being detected in groundwater in 2008 than were detected in 2005.

Hence, this assessment chiefly was conducted to identify testable hypotheses between land use and hydrogeologic characteristics and the occurrence and distribution of pesticides in shallow groundwater in Washington, D.C.

\section{Land Use}

A lack of information on pesticide use in urban areas within Washington, D.C. precludes a direct comparison of actual use in areas in proximity to each of the wells used for groundwater sample collection. To address this issue, patterns in land use in the Mid-Atlantic Coastal Plain have been used as surrogates for pesticide use and have been related to the occurrence and distribution of pesticides in Coastal Plain groundwater (Ator, 2008; Denver and Ator, 2006). A similar approach was adopted for this study. Land use within a circular buffer (500-m radius) of each well (Tyler and Belitz, 2009; Koterba and others, 1995) was characterized (table 4) on the basis of 2001 land-use data (Homer and others, 2004). For each circular buffer, the relative amounts of developed space (such as residential and commercial, major thoroughfares, and other structural development), and open space (such as water, woodland, and low-maintenance grassed areas) were determined.

Pesticide detections in groundwater in 2005 and 2008 were examined in relation to the amount of developed and open space within the circular buffer of each well in 2001 (fig. 7). Although fewer pesticides were detected in groundwater in 2005 than in 2008, the relation between the number of pesticides detected in groundwater and amount of developed land use is apparent in 2005 (fig. 7A). In 2008, with the exception of well WE $\mathrm{Cb} 8$, the number of pesticides detected in groundwater also appeared to increase with increases in the amount of developed space in the vicinity of the well (fig. 7B). Well WE Cb 8 was excluded from this analysis because the data were considered suspect.

Differences in the type of parkland, as well as proximity of parkland to development, could account for differences in the number and types of pesticides detected in shallow groundwater. In both years of data collection, most study sites associated with a high number of pesticide detections (at least five or more) in shallow groundwater tended to be in small municipal parks within developed areas, or near boundaries of large parks or other open space in close proximity to developed space (table 4, wells WE Ba 11, WE Ca 32, WE Cc 3, WW Bc 9, and WW Ac 8). Study sites associated with no or few pesticide detections tended to be located within the interior of large parklands or other open space (table 4, wells $\mathrm{AC}$ Aa 1, WE Bb 3, WE Ba 11, and WW Ba 28). Illustrative examples of the different land-use settings are provided as follows:

a. Examples of wells that yielded groundwater with high numbers of pesticide detections, located in open space (municipal parkland or wood and grasslands), but surrounded predominantly by extensively developed lands (fig. 8), and 
Table 4. Land use, geologic setting, and pesticide detections for groundwater-monitoring wells in Washington, D.C. sampled from September through December 2005 and (or) August through September 2008.

[USGS, U.S. Geological Survey; b.l.s., below land surface; L-M-H, sum of low-, medium-, and (or) high-density land-use areas, and as with other land uses, expressed as a fraction of circular area (in percent) within 500 meters of the well; parentheses around one of the categories, (-L), (-M), or (-H), indicate that category of residential land use is less than a few percent; Pot Fm, S; Potomac Formation, sand lithofacies; Pot Fm, C; Potomac Formation, clay lithofacies; Ter dep, Terrace deposits; Sap, Saprolite; Fm, Formation; H, herbicide(s); I, Insecticide(s); \%, percent; shaded areas denote paired-well sites]

\begin{tabular}{|c|c|c|c|c|c|c|}
\hline \multirow[b]{2}{*}{$\begin{array}{c}\text { USGS } \\
\text { well } \\
\text { identifier }\end{array}$} & \multirow[b]{2}{*}{ Dominant land uses ${ }^{1}$} & \multicolumn{3}{|c|}{ Detailed geologic setting² } & \multicolumn{2}{|c|}{$\begin{array}{l}\text { Number of pesticide } \\
\text { compounds detected }\end{array}$} \\
\hline & & $\begin{array}{l}\text { Depth of } \\
\text { screened } \\
\text { interval of } \\
\text { the well } \\
\text { (feet b.l.s.) }\end{array}$ & $\begin{array}{l}\text { Overburden } \\
\text { from land } \\
\text { surface to } \\
\text { screened } \\
\text { interval } \\
\end{array}$ & $\begin{array}{l}\text { Geologic unit } \\
\text { of screened } \\
\text { interval } \\
\text { (feet b.l.s.) }\end{array}$ & 2005 & 2008 \\
\hline \multicolumn{7}{|c|}{ Anacostia River watershed } \\
\hline $\mathrm{AC} \mathrm{Aa} 1$ & $\begin{array}{l}\text { Federal park on riverbank; } 50 \% \text { open } \\
\text { water and low-maintenance chiefly } \\
\text { grassed open space, } 39 \% \text { L-M-H den- } \\
\text { sity residential with sports complex }\end{array}$ & $25-30$ & $\begin{array}{l}\text { Unknown, } \\
\text { assumed fill } \\
\text { and clay }\end{array}$ & Alluvium & None & Not sampled \\
\hline $\begin{array}{l}\text { AC Aa } 6 \\
\text { and } \\
\text { AC Aa } 7\end{array}$ & $\begin{array}{l}\text { Federal park boundary area; } 28 \% \text { open } \\
\text { and low-maintenance grassed and } \\
\text { wooded open space; } 71 \% \text { L-M(-H) den- } \\
\text { sity residential and built-up parkland }\end{array}$ & $\begin{array}{l}12.5-18.5 \\
49.5-59.5\end{array}$ & $\begin{array}{l}\text { Alluvium, } \\
\text { no clay } \\
\text { Clay layer, } \\
\sim 17 \text { feet thick }\end{array}$ & Alluvium & $\begin{array}{l}\text { Not sampled } \\
\text { Not sampled }\end{array}$ & $\begin{array}{l}\text { None } \\
\text { None }\end{array}$ \\
\hline WE Ba10 & $\begin{array}{l}\text { Residential park boundary area; } 10 \% \text { low- } \\
\text { maintenance grassed and wooded open } \\
\text { space, } 90 \% \text { L-M-H density residential } \\
\text { and commercial }\end{array}$ & $7-17$ & $\begin{array}{l}\text { Silty, clayey } \\
\text { sand, } \sim 7 \text { feet } \\
\text { thick }\end{array}$ & Alluvium & None & Not sampled \\
\hline WE Ba11 & $\begin{array}{l}\text { Maintained grass median between road- } \\
\text { ways along development and recre- } \\
\text { ational park; } 22 \% \text { grassed and wooded } \\
\text { open space, } 77 \% \text { L-M(-H) residential } \\
\text { and commercial }\end{array}$ & $18.5-28.5$ & $\begin{array}{l}\text { Clay layer, } \\
\quad \sim 15 \text { feet thick }\end{array}$ & Pot Fm, C & Not sampled & $2 \mathrm{H}, 4 \mathrm{I}$ \\
\hline WE Ca 32 & $\begin{array}{l}\text { Grassed residential minipark; } 1 \% \text { open } \\
\text { and wooded open space; } 99 \%(\mathrm{~L}-) \mathrm{M}-\mathrm{H} \\
\text { density well-maintained residential and } \\
\text { commercial development }\end{array}$ & $19-29$ & Sand & Ter dep & $3 \mathrm{H}, 4 \mathrm{I}$ & $8 \mathrm{H}, 7 \mathrm{I}$ \\
\hline WE Ca 33 & $\begin{array}{l}\text { Grassed residential minipark; } 1 \% \text { grassed } \\
\text { and wooded open space; } 99 \% \text { (L-) M-H } \\
\text { density well-maintained residential and } \\
\text { commercial development }\end{array}$ & $28-38$ & Silty sand & Ter dep & $1 \mathrm{I}$ & Not sampled \\
\hline
\end{tabular}


Table 4. Land use, geologic setting, and pesticide detections for groundwater-monitoring wells in Washington, D.C. sampled from September through December 2005 and (or) August through September 2008.-Continued

[USGS, U.S. Geological Survey; b.l.s., below land surface; L-M-H, sum of low-, medium-, and (or) high-density land-use areas, and as with other land uses, expressed as a fraction of circular area (in percent) within 500 meters of the well; parentheses around one of the categories, (-L), (-M), or (-H), indicate that category of residential land use is less than a few percent; Pot Fm, S; Potomac Formation, sand lithofacies; Pot Fm, C; Potomac Formation, clay lithofacies; Ter dep, Terrace deposits; Sap, Saprolite; Fm, Formation; H, herbicide(s); I, Insecticide(s); \%, percent; shaded areas denote paired-well sites]

\begin{tabular}{|c|c|c|c|c|c|c|}
\hline \multirow[b]{2}{*}{$\begin{array}{c}\text { USGS } \\
\text { well } \\
\text { identifier }\end{array}$} & \multirow[b]{2}{*}{ Dominant land uses ${ }^{1}$} & \multicolumn{3}{|c|}{ Detailed geologic setting ${ }^{2}$} & \multicolumn{2}{|c|}{$\begin{array}{l}\text { Number of pesticide } \\
\text { compounds detected }\end{array}$} \\
\hline & & $\begin{array}{l}\text { Depth of } \\
\text { screened } \\
\text { interval of } \\
\text { the well } \\
\text { (feet b.l.s.) }\end{array}$ & $\begin{array}{l}\text { Overburden } \\
\text { from land } \\
\text { surface to } \\
\text { screened } \\
\text { interval }\end{array}$ & $\begin{array}{l}\text { Geologic unit } \\
\text { of screened } \\
\text { interval } \\
\text { (feet b.l.s.) }\end{array}$ & 2005 & 2008 \\
\hline WE Ca 34 & $\begin{array}{l}\text { Grassed roadside area of wooded strip } \\
\text { between thoroughfare and river; } 58 \% \\
\text { open water and space (cemetery), } 39 \% \\
\text { L-M-H density residential and com- } \\
\text { mercial }\end{array}$ & $13-33$ & Sand, silty sand & $\begin{array}{l}\text { Alluvium / } \\
\text { Ter dep }\end{array}$ & None & None \\
\hline $\begin{array}{l}\text { WE Cb } 5 \\
\text { and } \\
\text { WE Cb } 6\end{array}$ & $\begin{array}{l}\text { Grassed wooded area near aquatic gardens } \\
\text { and nursery; } 48 \% \text { open (aquatic ponds) } \\
\text { water and maintained grassed and } \\
\text { wooded space; } 36 \% \text { L-M(-H) residen- } \\
\text { tial and commercial }\end{array}$ & $\begin{array}{l}12.6-22.6 \\
36.3-46.3\end{array}$ & $\begin{array}{l}\text { Gravel and sand } \\
\text { Clay-silt layer, } \\
\sim 10 \text { feet thick }\end{array}$ & $\begin{array}{l}\text { Ter dep } \\
\text { Ter dep }\end{array}$ & $\begin{array}{l}\text { None } \\
\text { None }\end{array}$ & $\begin{array}{l}5 \mathrm{H} \\
\text { Not sampled }\end{array}$ \\
\hline WE Cb 8 & $\begin{array}{l}\text { Grassed edge of Federal park complex in } \\
\text { woodlands; } 48 \% \text { open maintained-grass } \\
\text { and woodland space, } 46 \% \text { L-M(-H) } \\
\text { density residential, sport recreational, } \\
\text { and built-up Federal parklands }\end{array}$ & $255-265$ & $\begin{array}{l}\text { Clay layer, } \\
\sim 215 \text { feet thick }\end{array}$ & Pot Fm, S & $1 \mathrm{H}$ & $6 \mathrm{H}, 2 \mathrm{I}^{3}$ \\
\hline $\begin{array}{l}\text { WE Cb } 11 \\
\text { and } \\
\text { WE Cb } 12\end{array}$ & $\begin{array}{l}\text { Grass (maintained) and wooded (stream) } \\
\text { buffer strip; } 30 \% \text { open wooded park } \\
\text { and maintained-grass space; } 69 \% \text { well- } \\
\text { maintained L-M-H density residential } \\
\text { and commercial development }\end{array}$ & $\begin{array}{l}16-21 \\
29-39\end{array}$ & $\begin{array}{l}\text { Fill and silt } \\
\text { Sandy clay layer, } \\
\sim 20 \text { feet thick }\end{array}$ & $\begin{array}{l}\text { Alluvium } \\
\text { Pot Fm, C }\end{array}$ & $\begin{array}{l}\text { None } \\
\text { None }\end{array}$ & $\begin{array}{l}\text { Not sampled } \\
\text { Not sampled }\end{array}$ \\
\hline
\end{tabular}


Table 4. Land use, geologic setting, and pesticide detections for groundwater-monitoring wells in Washington, D.C. sampled from September through December 2005 and (or) August through September 2008.—Continued

[USGS, U.S. Geological Survey; b.l.s., below land surface; L-M-H, sum of low-, medium-, and (or) high-density land-use areas, and as with other land uses, expressed as a fraction of circular area (in percent) within 500 meters of the well; parentheses around one of the categories, (-L), (-M), or (-H), indicate that category of residential land use is less than a few percent; Pot Fm, S; Potomac Formation, sand lithofacies; Pot Fm, C; Potomac Formation, clay lithofacies; Ter dep, Terrace deposits; Sap, Saprolite; Fm, Formation; H, herbicide(s); I, Insecticide(s); \%, percent; shaded areas denote paired-well sites]

\begin{tabular}{|c|c|c|c|c|c|c|}
\hline \multirow[b]{2}{*}{$\begin{array}{c}\text { USGS } \\
\text { well } \\
\text { identifier }\end{array}$} & \multirow[b]{2}{*}{ Dominant land uses' } & \multicolumn{3}{|c|}{ Detailed geologic setting² } & \multicolumn{2}{|c|}{$\begin{array}{l}\text { Number of pesticide } \\
\text { compounds detected }\end{array}$} \\
\hline & & $\begin{array}{l}\text { Depth of } \\
\text { screened } \\
\text { interval of } \\
\text { the well } \\
\text { (feet b.l.s.) }\end{array}$ & $\begin{array}{l}\text { Overburden } \\
\text { from land } \\
\text { surface to } \\
\text { screened } \\
\text { interval }\end{array}$ & $\begin{array}{l}\text { Geologic unit } \\
\text { of screened } \\
\text { interval } \\
\text { (feet b.l.s.) }\end{array}$ & 2005 & 2008 \\
\hline WW Bc 10 & $\begin{array}{l}\text { Grass (maintained) and wooded park area } \\
\text { along roadway between developments; } \\
\text { 19\% open grass and woodland space; } \\
79 \% \text { L-M-H density residential and } \\
\text { commercial }\end{array}$ & $22-32$ & $\begin{array}{l}\text { Silt } \sim 10 \text { feet } \\
\text { thick, clay } \\
\sim 5 \text { feet thick }\end{array}$ & Laurel Fm & Not sampled & None \\
\hline WW Bc 11 & $\begin{array}{l}\text { Grass (maintained) area near parking lot } \\
\text { of sports complex between reservoir } \\
\text { woodlands and development; } 46 \% \text { open } \\
\text { grass (maintained) and woodland space; } \\
49 \% \text { L-M(-H) density residential and } \\
\text { commercial }\end{array}$ & 28.4-38.4 & $\begin{array}{l}\text { Silty clay } \\
\text { (saprolite) }\end{array}$ & $\begin{array}{l}\text { Sap above } \\
\text { Laurel Fm }\end{array}$ & Not sampled & None \\
\hline WW Ac 8 & $\begin{array}{l}\text { Grass (maintained) and wooded (stream) } \\
\text { residential park buffer strip; } 18 \% \text { open } \\
\text { maintained grass and woodland space, } \\
\text { wooded park and maintained-grass } \\
\text { space; } 81 \% \text { well-maintained L-M-H } \\
\text { density residential and commercial }\end{array}$ & $23.6-33.6$ & Sand & $\begin{array}{l}\text { Sap above } \\
\text { Laurel Fm }\end{array}$ & Not sampled & $2 \mathrm{H}, 3 \mathrm{I}$ \\
\hline WW Ba $28^{3}$ & $\begin{array}{l}\text { Grass and wooded area between ma- } \\
\text { jor thoroughfare dividing reservoir } \\
\text { woodland and development; } 56 \% \text { open } \\
\text { (water) woodlands and maintained thor- } \\
\text { oughfare right-of-way; 33\% L-M(-H) } \\
\text { density residential and commercial }\end{array}$ & $50-100$ & $\begin{array}{l}\text { Silty clay } \\
\text { (saprolite), } \\
\sim 15 \text { feet thick }\end{array}$ & Sykesville Fm & Not sampled & None \\
\hline
\end{tabular}

\footnotetext{
${ }^{1} 2001$ land use(s) by type and area are from Homer and others (2004) and are expressed as a percentage of a circular area within 500 meters of the well (Tyler and Belitz, 2009; Koterba and others, 1995).

${ }^{2}$ Determined on the basis of available drilling logs from well installation and geologic units described and mapped by Southworth and Denenny (2006).

${ }^{3}$ WW Ba 28 is not located in Rock Creek watershed, but the geologic setting is similar and, therefore, is included in the table with Rock Creek watershed wells.
} 


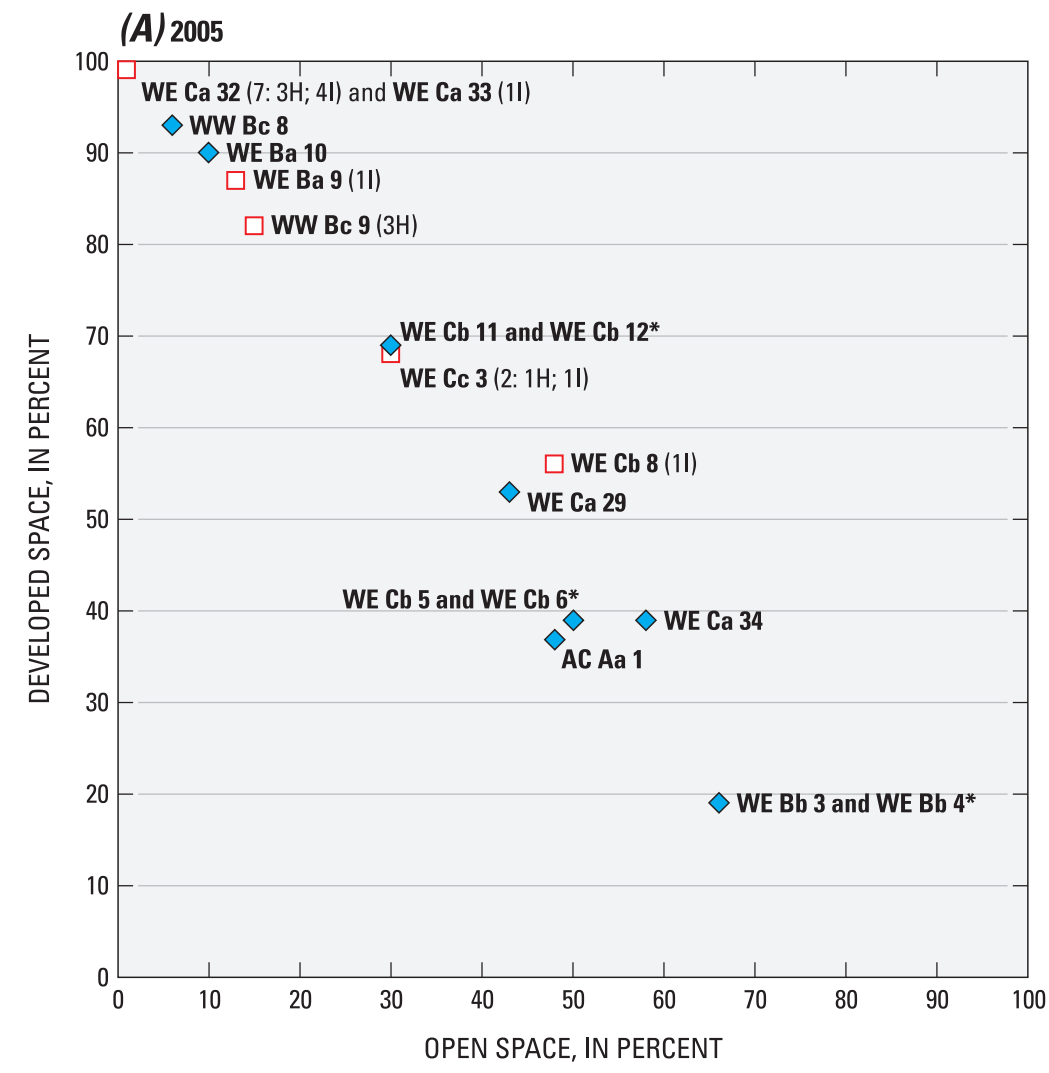

\author{
EXPLANATION \\ 2005 WELL SITES \\ $\diamond$ No (0) pesticides detected \\ $\square(\mathrm{N})$ pesticides detected and number: \\ $\mathrm{H}$, herbicide; I, insecticide \\ Sites with no pesticide residues detected, \\ listed in order of decreasing developed \\ (and generally increasing open) space: \\ WW Bc 8 \\ WE Ba 10 \\ WE Cb 11 and WE Cb 12* \\ WE Ca 29 \\ AC Aa 1 \\ WE Ca 34 \\ WE $\mathrm{Cb} 5$ and WE Cb 6 * \\ WE Bb 3 and WE Bb $4^{*}$
}

Sites with (N) pesticide residues detected listed in order of decreasing developed (and generally increasing open) space: WE Ca 32 (7) and WE Ca $33(1)^{*}$

WE Ba 9 (1)

WW Bc 9 (3)

WE Cc 3 (2)

WE Cb 8 (1)

* Samples collected from shallow and deep wells

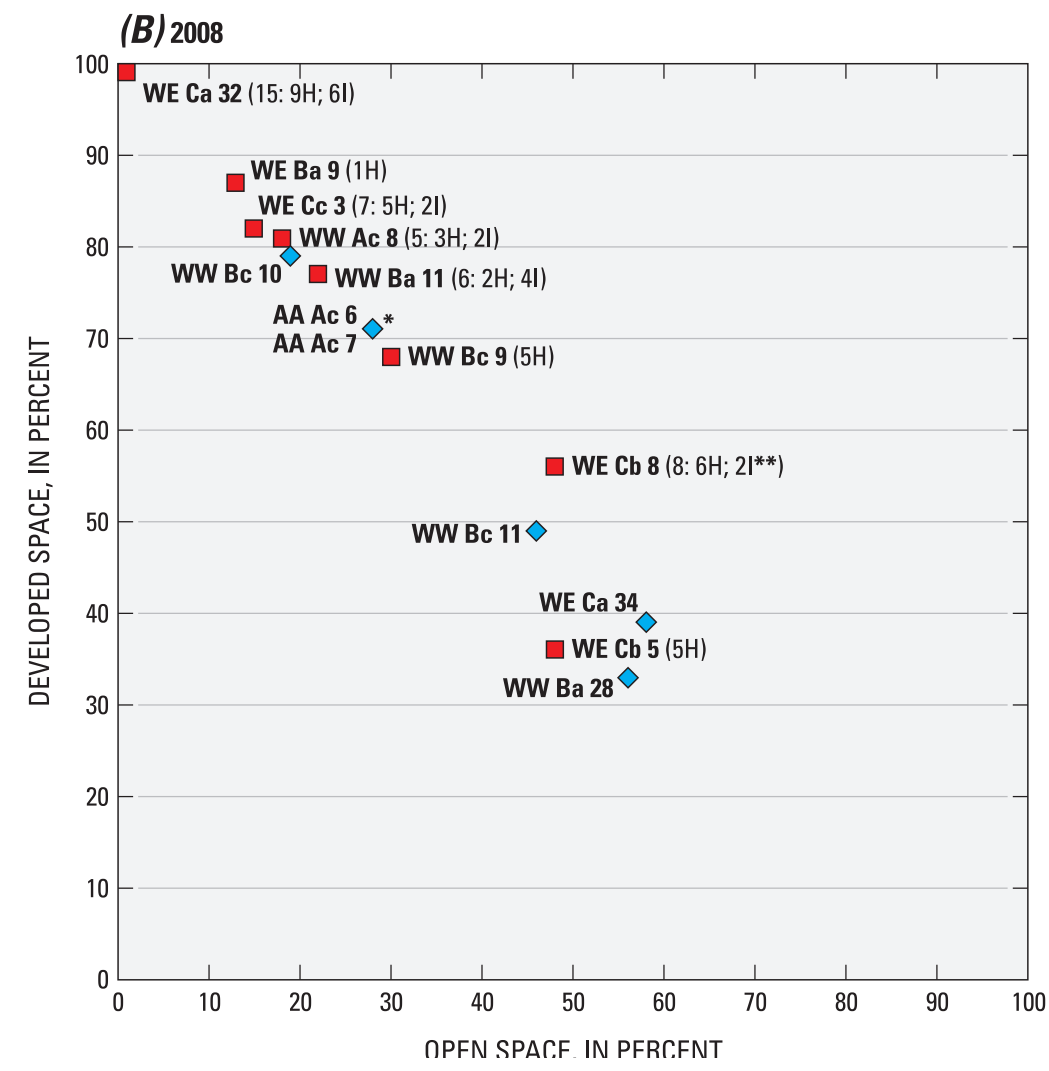

\section{EXPLANATION}

2008 WELL SITES

$\checkmark$ No (0) pesticides detected

$\square$ (N) pesticides detected and number:

$\mathrm{H}$, herbicide; $\mathrm{I}$, insecticide

Sites with no pesticide residues detected, listed in order of decreasing developed (and generally increasing open) space:

WW Bc 10

AA Ac 6 and AA Ac $7^{*}$

WW Bc 11

WE Ca 34

WW Ba 28

Sites with (N) pesticide residues detected, listed in order of decreasing developed (and generally increasing open) space: WE Ca 32 (15) WE Ba 9 (1)

WE Cc 3 (7)

WW Ac 8 (5)

WE Ba 11 (6)

WW Bc 9 (5)

WE Cb 8 (8)

WE Cb 5 (5)

* Samples collected from shallow and deep wells

Figure 7. Pesticide detections in groundwater samples collected in $(A) 2005$ and $(B) 2008$ in relation to the percentage of developed space (low, medium, and high-density residential, commercial, governmental, thoroughfare, and other structural) and open space (woodland, maintained grassland, and water) within 500 meters of each well used for sampling, lower Anacostia River and Rock Creek watersheds, Washington, D.C. 
b. Examples of wells that yielded groundwater with no detectable pesticides, located in open space (large parklands), and surrounded predominantly by open space or as much open as developed space (fig. 9).

Although no data generally are readily and routinely available on actual pesticide use in proximity to well locations, the policy on pesticide use at least within the large NPS parklands, such as Rock Creek Park and Anacostia Park, appears to be conservative and restricted to the local control of pests and invasives in selected recreational areas (for example, golf courses) and along roadways and bridges (Anderson and others, 2002). For example, Anderson and others (2002) found that in 1999, only two pesticides (glyphosate and triclopyr) were used along selected roadways throughout Rock Creek Park. They also noted that during 1999-2000, nine other pesticides were used on selected greens, approaches, or tees in the park golf course - carbaryl, chlorothalonil, lambda-cyhalothrin, dithiopyr, iprodione, mancozeb (dithio-carbamate), proprioconazole, proprionic acid, and thiophenate methyl. Of these 11 pesticides, laboratory analyses were conducted in the current study for glyphosate (including degradates), triclopyr, carbaryl, and proprioconazole in 2005 (Klohe and Debrewer, 2007, appendix 1) and in 2008 (appendix A, table A1). With the exception of glyphosate and its degradates, however, none of the above pesticides was detected in any 2005 or 2008 groundwater samples. Glyphosate was detected in the groundwater sample collected in 2008 from well WE Ba 11 in Fort Stanton Park, which is managed by the NPS.

Anderson and others (2002) found that almost four dozen different pesticides were applied to agricultural areas in nearby Montgomery County, Maryland in 1994 and 1997, including all the pesticides detected in groundwater in the current study. Montgomery County immediately borders the northern part of Washington, D.C. and includes the upper part of the Rock Creek watershed (fig.1). If similar pesticide uses occurred in developed lands within Washington, D.C. that border Rock Creek and other large parks, then multiple types of pesticides detected in groundwater at selected sites used in the current study could originate in the developed lands that border park sites.

Using land use as a surrogate for pesticide use has two notable limitations. First, at most only a few wells in this study are located in areas that could be considered almost entirely developed residential or commercial lands (wells WE Ca 32, WE Ba 9, WE Cc 3, WW Ac 8, and WW Bc 9). Second, pesticides were not always detected in shallow groundwater from wells surrounded by extensive urban development (fig. 10).

Given such limitations, at least several questions arise that, if answered, may explain variations in pesticide occurrence in shallow groundwater:

a. Do pesticide mixtures in shallow groundwater in parks and other open spaces reflect actual pesticide use within the parks or open spaces, or do they represent pesticide uses and groundwater transported from nearby developed space? b. Does markedly different pesticide usage exist in developed space in Washington, D.C. (for example among residential or commercial areas) that could account for groundwater samples with minimal pesticide concentrations from wells in nearby parkland?

c. Do differences in land use or subsurface infrastructure (for example, irrigation, density, direction, or age of storm or sewer drains) account for differences in pesticide detection in parklands bordering developments?

d. How do natural subsurface hydrogeologic conditions affect the transport and thus presence of pesticides in shallow groundwater in parklands or other open space?

Given the scope of the current study, only question (d) can be addressed (see following section).

\section{Hydrogeologic Factors}

Hydrogeologic setting affects the occurrence of pesticides in groundwater both nationally and regionally in the Coastal Plain and Piedmont Physiographic Provinces. In the surficial aquifer in the Coastal Plain adjacent to Washington, D.C., pesticides in groundwater occur mostly in well-drained areas with highly permeable soils and aquifer sediments (Ator, 2008; Denver and Ator, 2006). Regional studies in the Coastal Plain adjacent to Washington, D.C. have shown that in recharge settings that favor the transport of water-soluble pesticides, the vertical distribution of pesticides in the shallow surficial aquifer is a function of well depth. Pesticides in these settings often are accompanied by other anthropogenic contaminants, such as elevated concentrations of nutrients - presumably from fertilizers, septic systems, and leaky sewer lines; and (or) chloride - presumably from septic systems, leaky sewer lines, or road-salt applications (Ator, 2008; Denver and Ator, 2006; Shedlock and others, 1999; Focazio and others, 1998; Hamilton and others, 1993).

\section{Pesticide Detections and Types of Surficial Sediment}

Recharge to the unconfined surficial aquifer in the Anacostia River watershed in Washington, D.C. chiefly is the result of infiltration in areas with permeable surficial sediments (S.W. Ator, U.S. Geological Survey, written commun., 2010). A similar argument can be made in relation to groundwater in the Rock Creek watershed. One can hypothesize that the presence of pesticides in groundwater could be related to differences in the permeability of surficial sediments in the vicinity of the wells used for this study. Specific wells were selected or installed to reflect different surficial geologic materials (table 1). To test this hypothesis, detailed drilling logs were examined for most of the wells. Wells initially were grouped by geologic unit, and within each unit, lithologic logs were examined for the presence of low-permeability sediment 
(A)

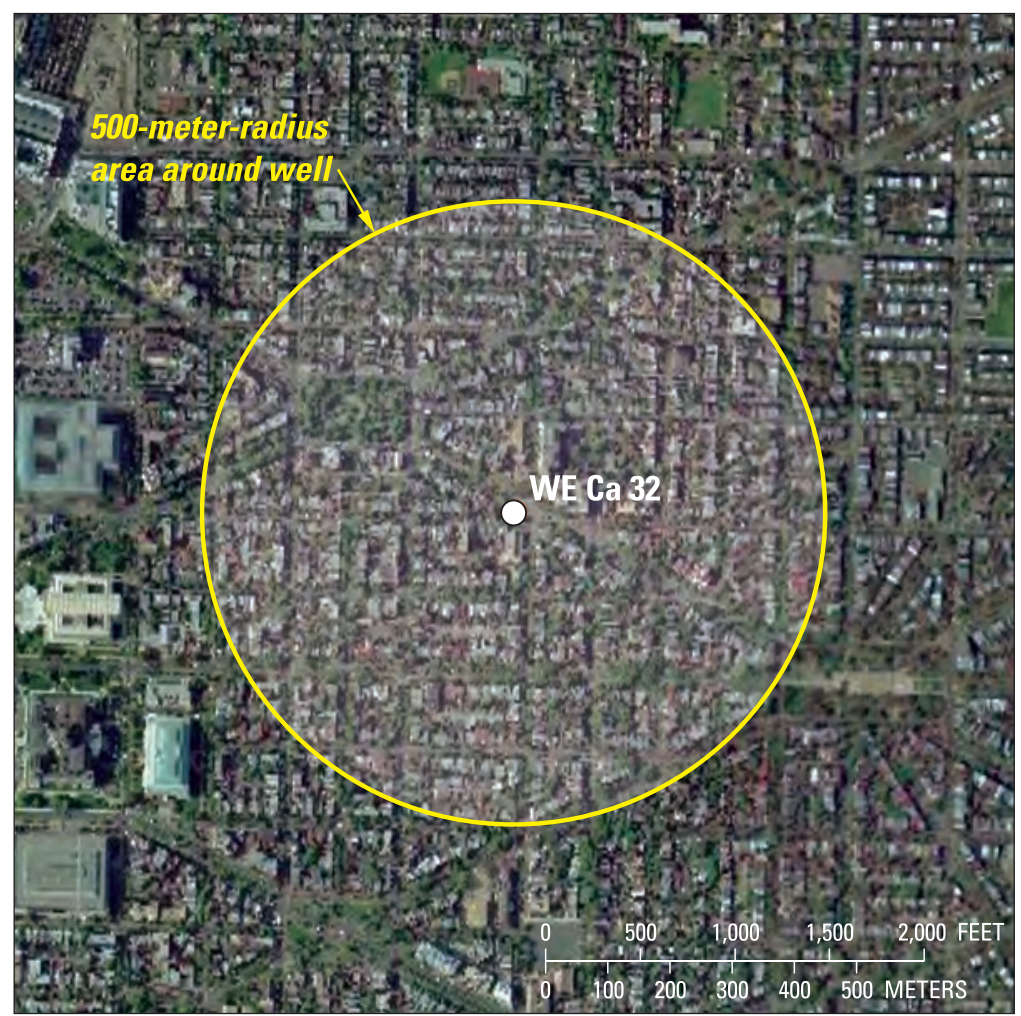

(B)

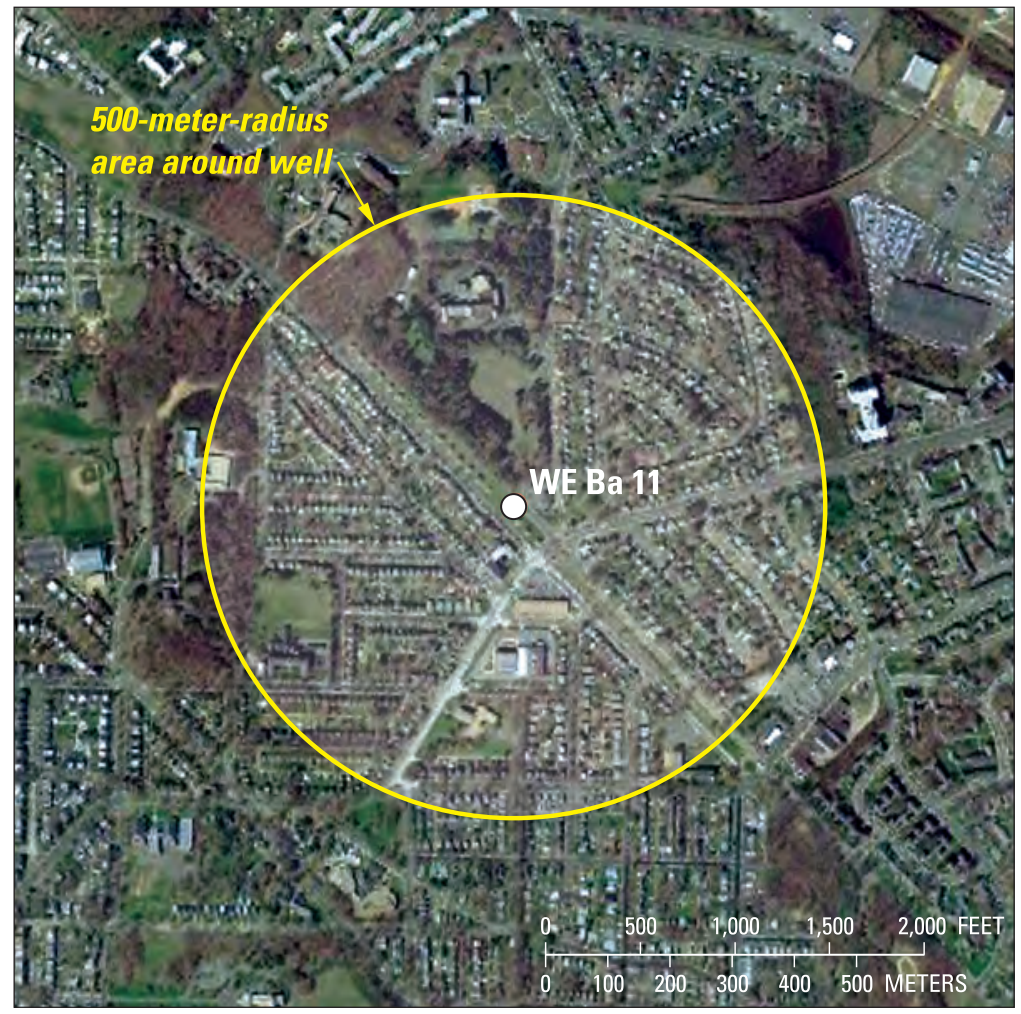

\section{EXPLANATION}

WELL WE Ca 32

15 PESTICIDE RESIDUES

\section{LAND USE WITHIN 500-METER-RADIUS} AREA AROUND WELL

99 PERCENT EXTENSIVELY DEVELOPED LANDS 1 PERCENT OPEN SPACE

\author{
EXPLANATION \\ WELL WE Ba 11 \\ 6 PESTICIDE RESIDUES \\ LAND USE WITHIN 500-METER-RADIUS \\ AREA AROUND WELL \\ 77 PERCENT EXTENSIVELY DEVELOPED LANDS \\ 22 PERCENT OPEN SPACE
}

Figure 8. Examples of extensively developed land within 500 meters of two wells, (A)WE Ca 32 and (B)WE Ba 11, which in 2008 yielded groundwater samples that contained mixtures of six or more different pesticide compounds, lower Anacostia River watershed, Washington, D.C. [Aerial photographs from U.S. Department of Agriculture (USDA) National Agriculture Imagery Program (NAIP).] 
(A)

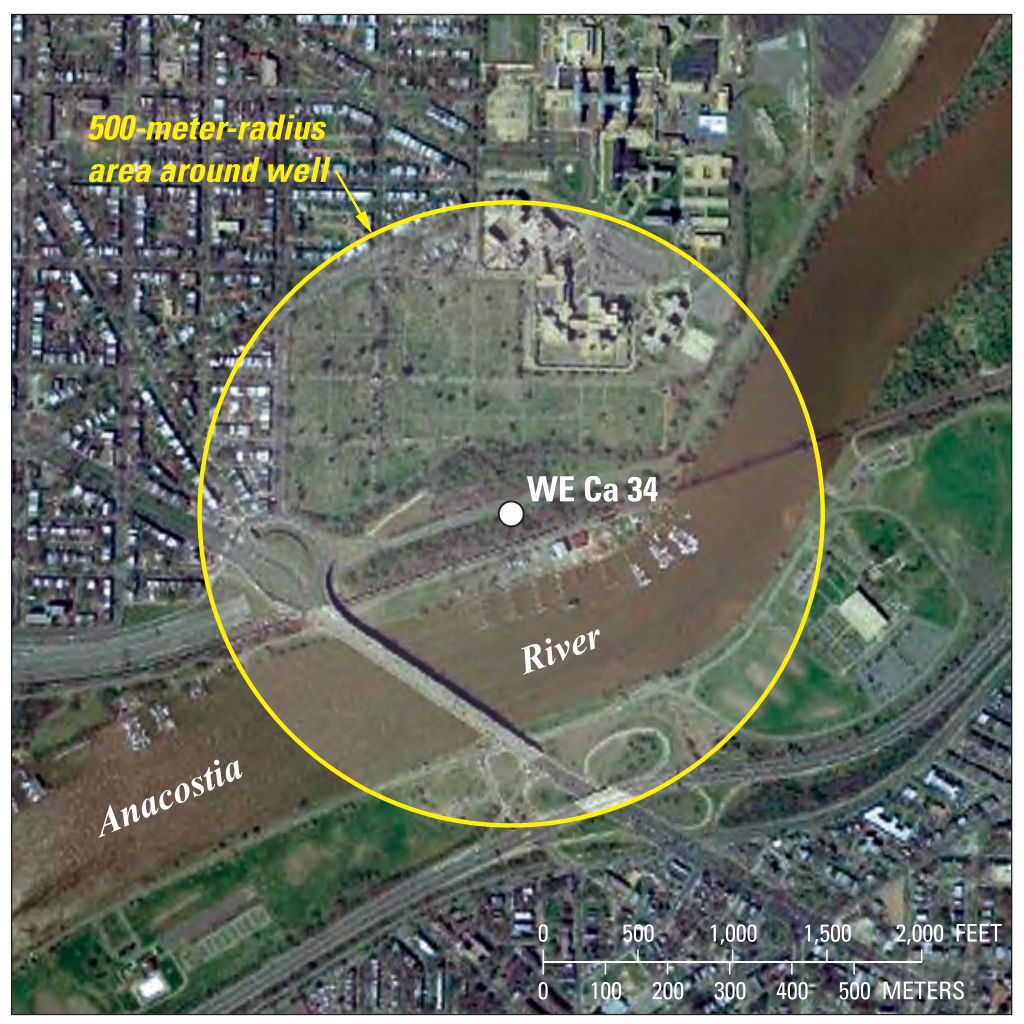

EXPLANATION

W WELL WE Ca 34

NO PESTICIDE RESIDUES

LAND USE WITHIN 500-METER-RADIUS AREA AROUND WELL

39 PERCENT LOW-TO-MODERATELY

DEVELOPED LANDS

58 PERCENT OPEN SPACE
(B)

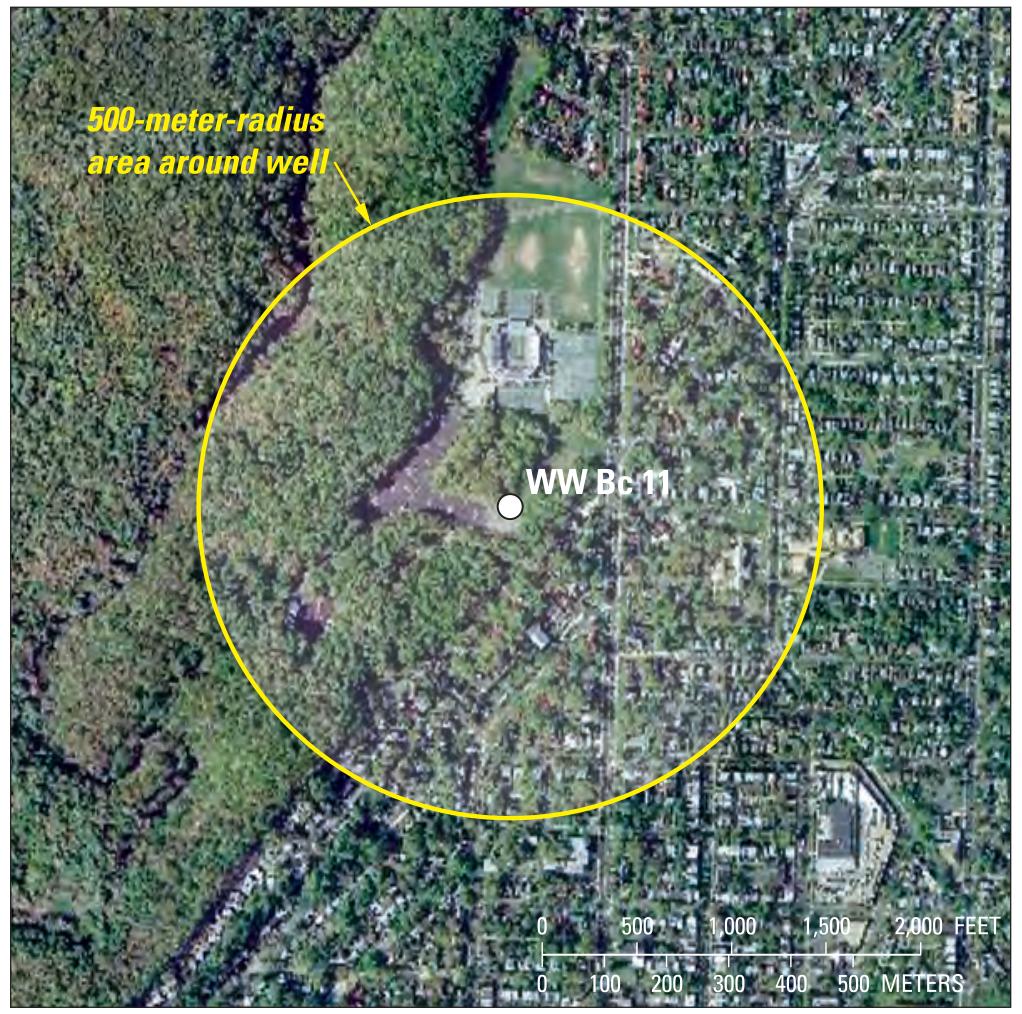

EXPLANATION

WELL WW Bc 11

NO PESTICIDE RESIDUES

LAND USE WITHIN 500-METER-RADIUS AREA AROUND WELL

49 PERCENT LOW-TO-MODERATELY DEVELOPED LANDS

46 PERCENT OPEN SPACE

Figure 9. Examples of low-to-moderately developed land within 500 meters of two wells, (A) WE Ca 34 and (B) WW Bc 11, which in 2008 yielded groundwater samples that contained no detectable pesticide compounds, lower Rock Creek and Anacostia River watersheds, Washington, D.C. [Aerial photographs from U.S. Department of Agriculture (USDA) National Agriculture Imagery Program (NAIP).] 
(A)

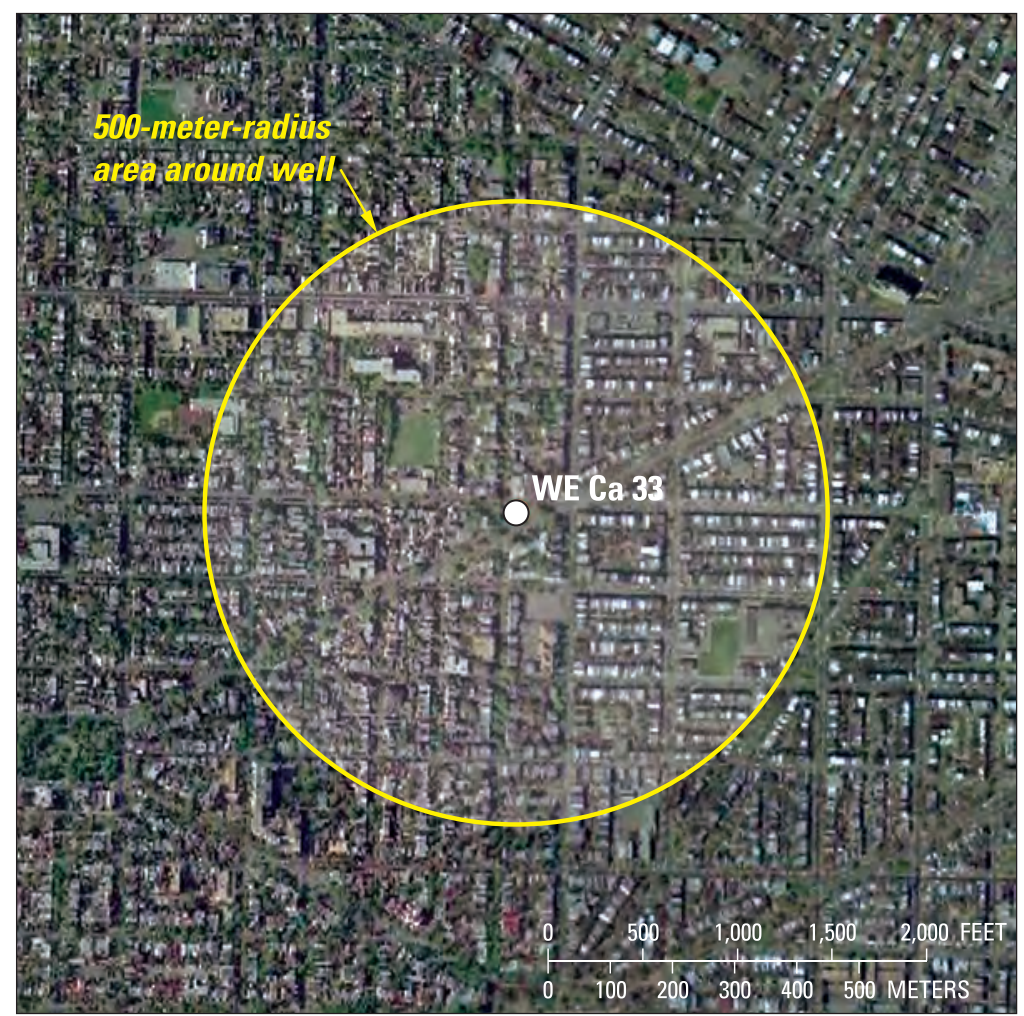

(B)

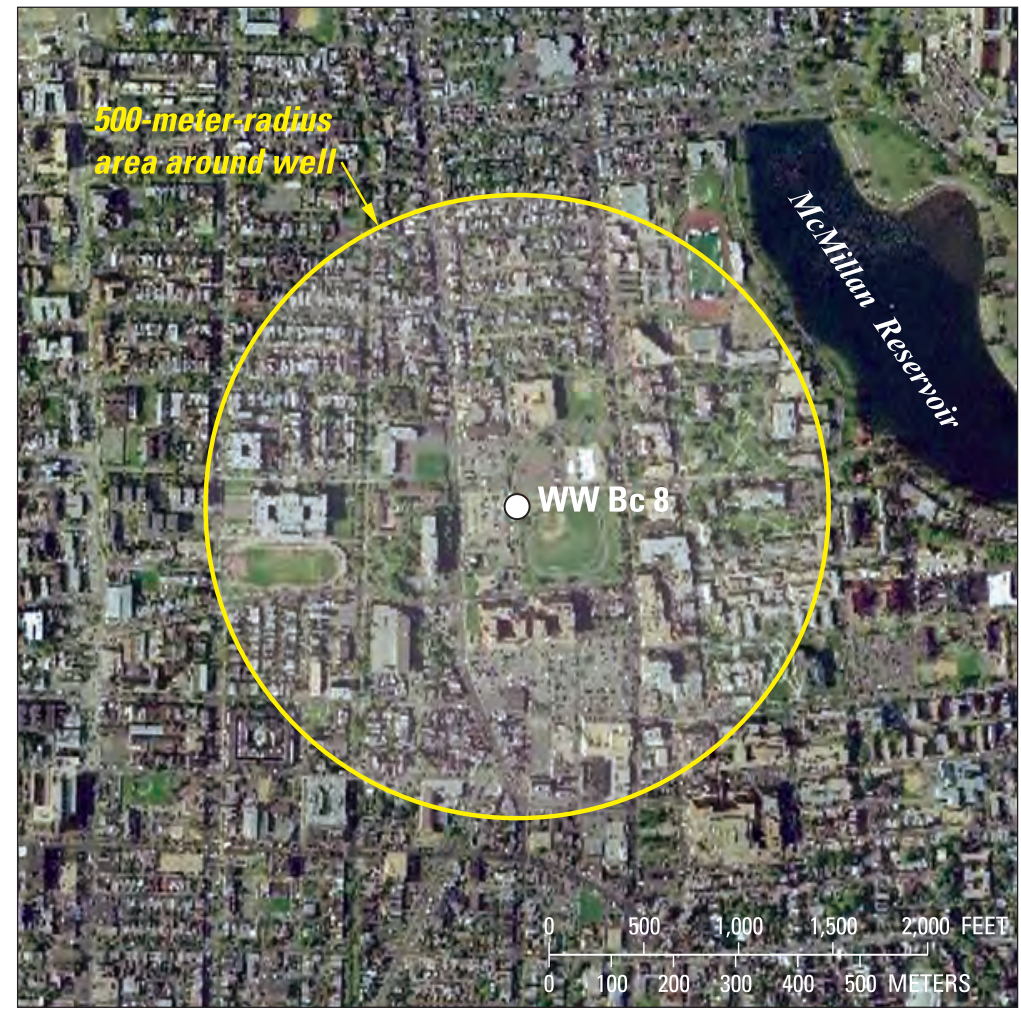

\section{EXPLANATION}

O WELL WE Ca 33

1 RESIDUE DETECTED IN 2005

NOT SAMPLED IN 2008

LAND USE WITHIN 500-METER-RADIUS AREA AROUND WELL

99 PERCENT EXTENSIVELY DEVELOPED LANDS 1 PERCENT OPEN SPACE

Figure 10. Examples of extensively developed land within 500 meters of two wells, (A)WE Ca 33 and (B) WW Bc 8, which in 2005 yielded groundwater samples that contained one or no detectable pesticide compounds, lower Anacostia River watershed, Washington, D.C. [Aerial photographs from U.S. Department of Agriculture (USDA) National Agriculture Imagery Program (NAIP).] 
layers, defined as having appreciable silt, silty-clay or clay layers at least 10 feet thick (table 4). Pesticide detections were examined in relation to this characterization of overburden sediments, and the results are summarized by geologic unit (table 5).

Except for wells completed chiefly in outcrop or subcrop areas of the Potomac Formation, pesticide mixtures were present in groundwater samples in most wells completed in geologic units that were not overlain by low-permeability layers (table 5). In most settings, groundwater that contained pesticide mixtures occurred where clay, silty-clay, or silt layers 10 or more feet in thickness were absent.

For wells completed in the outcrop or subcrop areas of the Potomac Formation, with either clay or sand lithofacies, the presence or absence of pesticides in groundwater samples did not appear to relate to the proximity of low-permeability sediments (table 5). Why this discrepancy chiefly occurs for wells located in the Potomac Formation is unknown. It could be the result of the heterogeneous interbedding of sand, silt, and clay lenses of limited spatial extent. If low-permeability sediments are limited in spatial extent, groundwater contaminated with pesticides could move through the surficial aquifer into the Potomac Formation (for example, table 4, wells WE Ba 11 or WW Bc 9).

\section{Pesticide Detections and Well Depths}

Concentrations of pesticides in groundwater in the Maryland Coastal Plain have been shown to generally decline with depth in the surficial aquifer; the decline has been related to differences in the apparent age of the water since recharge, with most pesticides occurring in recently recharged and relatively young or modern age (post-1950) water (Debrewer and others, 2007; Shedlock and others, 1999; Focazio and others, 1998; Koterba and others, 1993; Shedlock and others, 1993). Apparent age is used because the age of modern (post-1940) groundwater generally is determined relative to the measured concentrations of modern contaminants - such as tritium from atomic weapons testing, and chlorofluorocarbon (CFC) compounds associated with commercial aerosol products - and necessarily presumes that the occurrence and concentrations of these contaminants in groundwater relate to natural groundwater recharge from atmospheric precipitation. Thus, the apparent age is relative and approximate, and, in urban areas, often cannot be accurately estimated because CFC concentrations in groundwater often reflect sources other than recharge from atmospheric precipitation. In urban areas such as Washington, D.C., local sources of modern contaminants commonly used to determine groundwater age, chiefly CFC concentrations, reflect recharge from multiple sources, such as atmospheric precipitation, landscape irrigation, and leaky infrastructure (water, sewer, and septic systems), which preclude the use of current dating methods.

Despite the limitations for dating groundwater within the surficial aquifer of the Coastal Plain in Washington, D.C., the presence of pesticides does appear to be associated with groundwater that is relatively shallow in depth and, therefore, relatively young in age. Pesticide detections chiefly occurred in samples collected from wells completed at shallow depths - median depth $19 \mathrm{ft}$ and maximum depth $28 \mathrm{ft}$ below land surface to the top of the well screen. The notable exception to the above was well WE $\mathrm{Cb} 8$, which yielded groundwater samples in 2005 and in 2008 with detectable pesticides, but has a screened interval of $255 \mathrm{ft}$ to $265 \mathrm{ft}$ below land surface, and an overburden that contains a clay layer approximately $215 \mathrm{ft}$ thick, which indicates this well is completed in the Potomac Group confined aquifer. The quality of the data obtained from this well, however, is considered suspect (appendix B).

\section{Pesticide Detections and Groundwater Ionic Chemistry}

Regional studies of the surficial aquifer in the Maryland Coastal Plain have shown that under natural conditions, the major-ion chemistry of groundwater typically reflects: (a) the low-level contributions of dissolved solids (cations and anions) found in precipitation, and (b) elevated concentrations of selected cations and anions from the dissolution of natural bedrock or unconsolidated sediments under either unconfined (oxic) or semi-to-confined (hypoxic-to-anoxic) conditions (Ator, 2008; Denver and Ator, 2006; Hamilton and others, 1993). Under oxic conditions, natural groundwater has been described as having low ionic strength, chiefly calcium/ magnesium carbonate waters with nitrate-nitrogen concentrations less than $0.4 \mathrm{mg} / \mathrm{L}$, chloride concentrations less than 6 $\mathrm{mg} / \mathrm{L}$, and sulfate concentrations of approximately 6 to $7 \mathrm{mg} / \mathrm{L}$ (Hamilton and others, 1993).

When pesticides are detected in groundwater in the Coastal Plain in Maryland, other evidence of human activities is usually present, and can include many of the same chemical indicators noted above, but at concentrations greater than those noted above (Klohe and Debrewer, 2007; Shedlock and others, 1999; Denver and Ator, 2006; Ator, 2008; Focazio and others, 1998; Hamilton and others, 1993). Examples include:

a. Elevated concentrations of nutrients, such as nitrate or ammonium, that presumably relate to human activities, such as the disposal and transport of human sewage (septic systems and leaky sewer lines), the disposal or use of domestic animal wastes, and the use of fertilizers, whether for agriculture or residential lawns and gardens; and

b. Elevated concentrations of sodium and chloride that relate to the disposal and transport of human sewage (septic systems and leaky sewer lines), the disposal or use of domestic animal wastes, or the use of deicing agents along transportation corridors.

Contaminated groundwater also may contain synthetic organic compounds, such as pesticides that are used in agricultural or urban settings, and in urban areas, and semi-volatile and 
Table 5. Geologic formations, overburden sediment, and pesticide occurrence in groundwater samples collected from monitoring wells in Washington, D.C., 2005 and 2008.

[NS, no samples collected]

\begin{tabular}{|c|c|c|c|}
\hline \multirow[t]{2}{*}{$\begin{array}{l}\text { Surficial geologic formation of } \\
\text { screened interval of well }\end{array}$} & \multicolumn{2}{|c|}{$\begin{array}{l}\text { Number of wells with one or } \\
\text { more pesticide detections } \\
\text { (Total number of wells sampled) }\end{array}$} & \multirow[t]{2}{*}{$\begin{array}{l}\text { Overburden sediment characteristics } \\
\text { and relation to pesticide occurrence }\end{array}$} \\
\hline & 2005 & 2008 & \\
\hline Alluvium deposits & $0(6)$ & $0(1)$ & $\begin{array}{l}\text { All wells had apparent silt, clay, or silty clay layers at least } 10 \\
\text { feet thick. }\end{array}$ \\
\hline Terrace deposits & 2(5) & $2(3)$ & $\begin{array}{l}\text { Wells with detections had no apparent silt or clay layers; wells } \\
\text { without detections had apparent silt or clay layer at least } 10 \\
\text { feet thick. }\end{array}$ \\
\hline Potomac Formation, sand lithofacies & $3(4)$ & $3(4)$ & $\begin{array}{l}\text { Detection occurrence did not relate to wells with overlying clay, } \\
\text { silt, or silty clay layers. }\end{array}$ \\
\hline Potomac Formation, clay lithofacies & $1(2)$ & $2(2)$ & $\begin{array}{l}\text { Detection occurrence did not relate to wells with overlying clay } \\
\text { or sandy clay layers. }\end{array}$ \\
\hline Saprolite overlying Laurel Formation & NS & $1(2)$ & $\begin{array}{l}\text { Well with detection had no apparent silt or clay layer; well with- } \\
\text { out detection had apparent clay layer at least } 10 \text { feet thick. }\end{array}$ \\
\hline Laurel and Sykesville Formations & NS & $0(2)$ & $\begin{array}{l}\text { Both wells had either silt plus clay layer or silty clay layer at } \\
\text { least } 10 \text { feet thick. }\end{array}$ \\
\hline
\end{tabular}

volatile organic compounds in urban settings from fuels, paint thinners, degreasing solvents, and dry-cleaning operations.

The major-ion chemistry for groundwater data obtained by Klohe and Debrewer (2007) in 2005 was analyzed for the surficial aquifer in the Anacostia River watershed in the eastern part of Washington, D.C. (S.W. Ator, U.S. Geological Survey, written commun., 2010). These data were related to three different geologic settings-Holocene alluvium (including overlying fill deposits), upper Tertiary and younger terrace deposits, and outcrop and subcrop parts of the Potomac Formation. Although the limited number of sites (17), different geologic settings (3), complexity of sediment types and redox conditions, and variability in land use made it difficult to broadly and quantitatively define the chemistry of natural and contaminated groundwater in the Coastal Plain in Washington, D.C., it was concluded that groundwater chemistry in this Coastal Plain setting reflects redox conditions.

Little information is available on the chemistry of natural and contaminated groundwater in the Piedmont or PiedmontCoastal Plain transition zone in the Rock Creek watershed in and near Washington, D.C. There are few monitoring wells, particularly wells completed in the weathered bedrock (saprolite); existing wells generally are completed in the fractured bedrock below the saprolite. The geologic composition of that bedrock has been described as highly variable and this variability would be reflected in the chemistry of groundwater.

To assess whether the presence of pesticides in groundwater in this study could be related to differences in surficial geologic settings or their groundwater chemistry, the approach used by S.W. Ator (U.S. Geological Survey, written commun.,
2010) was adopted and modified for this study. An emphasis was placed on (a) identifying and describing the major-ion chemistry of groundwater at each well site within a geologic setting and in relation to pesticide detections, and (b) identifying the apparent redox state of groundwater at each well site and relating this state to pesticide detections in groundwater. Major-ion chemistry is described with trilinear diagrams. Groundwater is defined as oxic if (a) nitrate-nitrogen occurred in excess of $5 \mathrm{mg} / \mathrm{L}$, and was generally greater than $10 \mathrm{mg} / \mathrm{L}$, (b) there was little to no measureable ammonium (approximately $0.2 \mathrm{mg} / \mathrm{L}$ or less), and (c) the iron concentration was less than $0.25 \mathrm{mg} / \mathrm{L}$; otherwise, groundwater is considered to reflect reduced conditions or a mixture of oxic and reduced waters. In addition, the scope of characterization was expanded on the Anacostia River watershed to include all geologic settings represented by wells located in Washington, D.C. used in this study. Thus, groundwater data collected from all wells sampled in the current study were considered.

The major-ion chemistry of shallow groundwater differed among and within the selected surficial geologic settings (table 6 and fig. 11). The presence of pesticides in groundwater, however, appeared to depend more on the permeability of the sediments within the geologic setting and the chemistry of groundwater associated with those sediments. The results by setting follow.

Alluvium - (Wells: AC Aa 1, AC Aa 6, WE Ba 10, WE Ca 29, WE Cb 11, WE Bb 3, and WE Bb 4) -Under oxic conditions (table 6), groundwater generally appeared as a moderately acidic ( $\mathrm{pH}$ less than 5.5 standard units) calciumbicarbonate water (for example, well WE Ba 10). At very 
shallow depths (for example, well WE Ba 10, $7 \mathrm{ft}$ to top of screen) or sandier sediments (for example, well AC Aa 6), groundwater appeared to be affected by human activities and was a calcium-sulfate/chloride water with elevated nitrate (>5 mg/L). Groundwater samples from most (5 of 7) wells completed in alluvium, however, reflected reduced, or mixed redox conditions, and a weakly acidic ( $\mathrm{pH} 6$ to 7), calcium/ iron-bicarbonate water. These waters also contained measurable ammonium (in excess of $0.2 \mathrm{mg} / \mathrm{L}$ ), but no measurable nitrate $(<0.01 \mathrm{mg} / \mathrm{L})$, variable chloride, and low-to-no measureable sulfate $(<2.7 \mathrm{mg} / \mathrm{L})$.

Regardless of redox condition, and despite evidence that groundwater appeared to be affected by anthropogenic activities as indicated by elevated concentrations of inorganic nitrogen (ammonium or nitrate) and, in some locations, elevated concentrations of chloride and sulfate $(>60 \mathrm{mg} / \mathrm{L})$, no pesticide residues were detected in any of the wells completed in alluvium (table 6, and fig. 12). Ator (2008) noted that pesticides were less likely to occur in alluvial (silty-clay) sediments than in other Coastal Plain sediments and attributed this to their relatively low permeability, and the absorption and possible degradation of pesticides.

Except for well AC Aa 6, no sampling was conducted in 2008 in wells completed in alluvium sediments. Well AC Aa 6 is surrounded by 70 percent development, and was completed at relatively shallow depth in sandy sediments with no indication of an impermeable layer (table 6), but there were no measureable pesticide residues in this well. Other indications of anthropogenic effects at this location suggest that this may have been an anomaly and these results remain unexplained.

Terrace deposits-(Wells WE Cb 5, WE Cb 6, WE Ca 32, WE Ca 33, and WE Ca 34)_Results of analysis of groundwater samples from wells screened in terrace deposits indicate groundwater chemistry differed among sites (fig. 11) at least in part because of redox conditions (table 6). Shallow groundwater at two sites (table 6, well WE Ca 32 and well WE $\mathrm{Cb} 5$ ), was present under oxic conditions, acidic ( $\mathrm{pH}$ 5.5), and a calcium- (or sodium-) sulfate (or chloride) type water, with elevated concentrations of sodium $(>9 \mathrm{mg} / \mathrm{L})$, nitrate $(>25 \mathrm{mg} / \mathrm{L})$, and chloride ( $>27 \mathrm{mg} / \mathrm{L})$. Samples of groundwater from these oxic terrace wells contained five or more pesticide compounds. Groundwater at the three other terrace sites was under reducing or mixed redox conditions, weakly acidic-to-neutral (pH 6.2 to 7.4), and defined as a calcium/ sodium/iron-bicarbonate water type, possibly with low-to-elevated ammonium, and no measureable nitrate. At well WE Cb 6 , groundwater appeared to be in a reduced state, and did not appear to be affected by human activities. Groundwater samples from wells WE Ca 33 and WE Ca 34 indicated anthropogenic contamination, in the form of elevated concentrations of sodium, ammonium, chloride, and (or) sulfate. Among these three wells, only well WE Ca 33 had a detectable pesticide.

Collectively, the groundwater chemistry of terrace deposits indicated that, except for well $\mathrm{WE} \mathrm{Cb} 6$, groundwater in permeable sediments under oxic conditions was affected by human activities and contains pesticide mixtures, whereas groundwater in permeable sediments under mixed redox conditions also was affected by human activities, but contained few if any pesticides. Groundwater in terrace deposits with impermeable sediments (for example, WE $\mathrm{Cb}$ 6) was in a reduced state, and did not appear to be affected by human activities.

Potomac Formation, sand or clay lithofacies - (Wells WE Cc 3, WE Ba 11, WW Bc 8, WW Bc 9, WE Cb 12, WE $\mathrm{Ba} 9$, WE Cb 8, and AC Aa 7)_-Except for WE Cb 8, wells in the Potomac Formation had 68 to 93 percent developed land use within the buffer area and were completed in shallow outcrop and subcrop areas with screened intervals beginning approximately 13 to $50 \mathrm{ft}$ below land surface (table 4). Well WE Cb 8 was considered an outlier of the study. Although completed in the Potomac Formation, it is surrounded by 46 percent development, and completed in the confined part of this formation below $215 \mathrm{ft}$ of clay at a depth of approximately $255 \mathrm{ft}$ below land surface. Except for the detection of pesticides (one in 2005 and eight in 2008), analysis of the chemistry of groundwater at this well indicated groundwater was present under reducing conditions with no other evidence of anthropogenic contamination, which indicated a well whose water quality possibly had been compromised (appendix B). Except for well WE Cc3, the shallow overburden for each of the Potomac Formation wells contained relatively thick (generally $10 \mathrm{ft}$ or more) impermeable (clay, silty clay, or sandy clay) sediments above the well screen, regardless of whether the sediments had been classified as sand or clay lithofacies (table 4). Well WE Cc 3 had a silty sand overburden with no evidence of an impermeable layer.

Groundwater chemistry in the shallow part of this formation differed among sites (fig. 11). Under oxic conditions (table 6), samples from four wells indicated groundwater was moderately to slightly acidic ( $\mathrm{pH} 4.7$ to 6.6), of a sodium/ calcium-chloride/sulfate water type, and contained elevated concentrations of nitrate $(>12 \mathrm{mg} / \mathrm{L})$. Shallow wells with oxic groundwater (WE Cc 3, WE Ba 11, and WW Bc 9) and elevated concentrations of anthropogenic-related contaminants also contained five or more pesticides. Groundwater with reduced, or mixed redox conditions did not appear to be as affected by human activity as oxic groundwater, as evidenced by only slightly acidic ( $\mathrm{pH} 5.7$ to 6.8 ), and, except for well WE Ba 9, a calcium-bicarbonate signature with little nitrate or ammonium (table 6). Only one pesticide was detected in groundwater with mixed redox state. That detection was in the groundwater sample from well WE Ba 9 along with other indicators of contamination (table 6), namely, elevated concentrations of ammonium $(>0.8 \mathrm{mg} / \mathrm{L})$, chloride $(>25 \mathrm{mg} / \mathrm{L})$, and sulfate $(>85 \mathrm{mg} / \mathrm{L})$.

Collectively, the presence of pesticide mixtures and contamination in shallow groundwater in this formation appeared related to redox conditions, and independent of the sand or clay lithofacies, or even the presence of an observed impermeable layer in the overburden sediments of the wells used in this study. One possible explanation for the occurrence of anthropogenically contaminated groundwater beneath impermeable 
む|

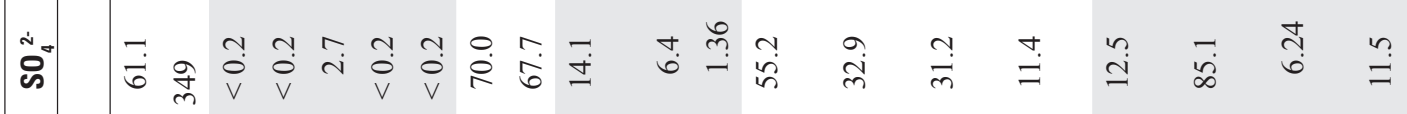

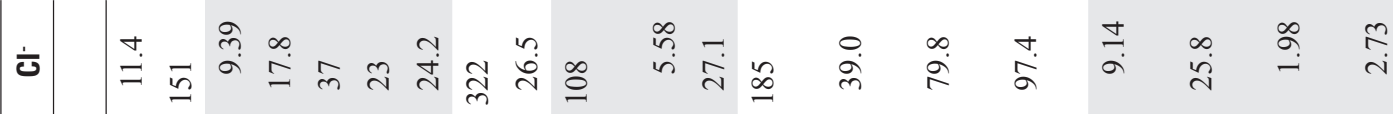

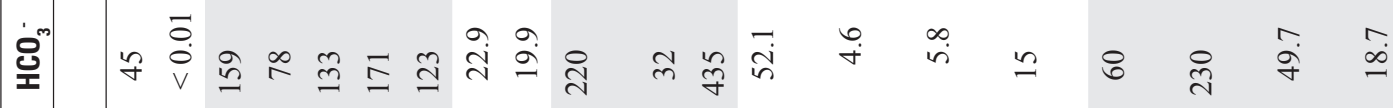

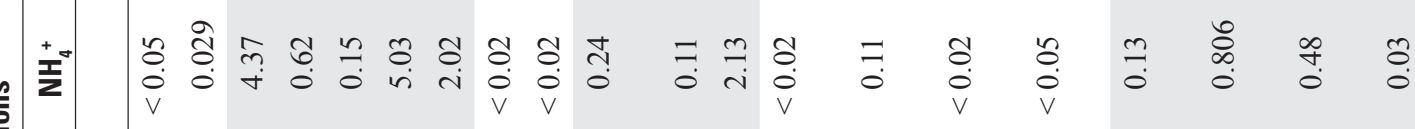

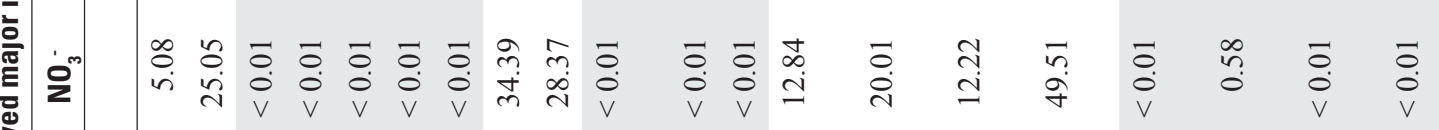

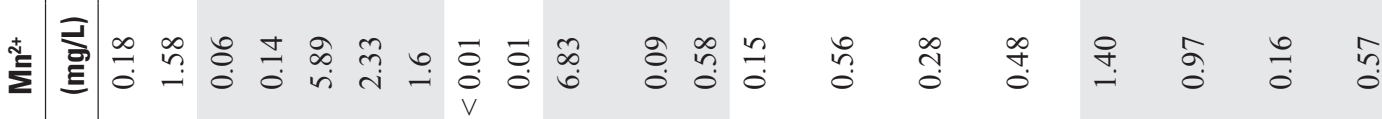

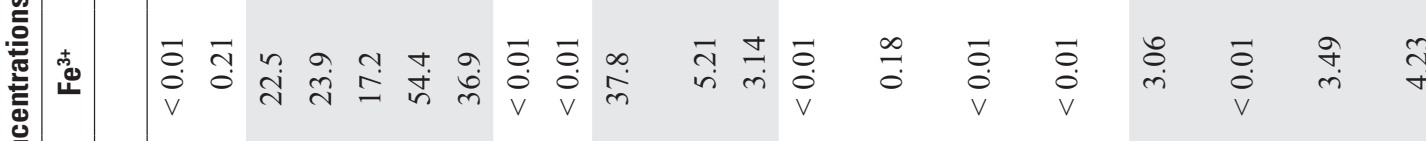

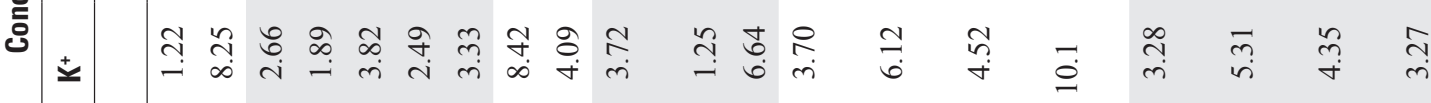

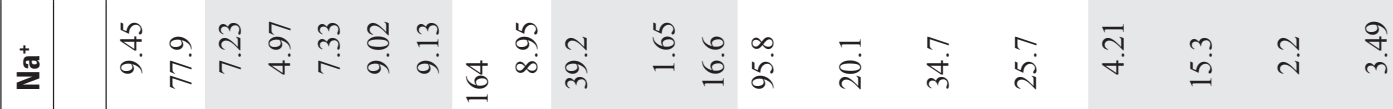

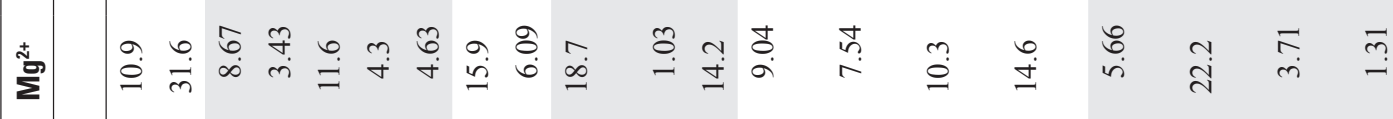
đ্்

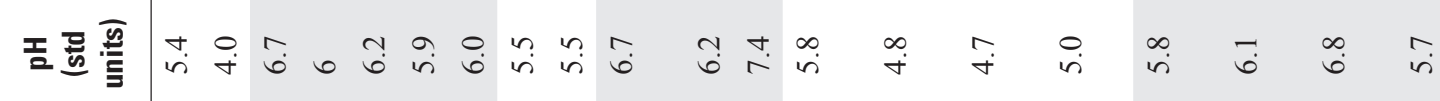

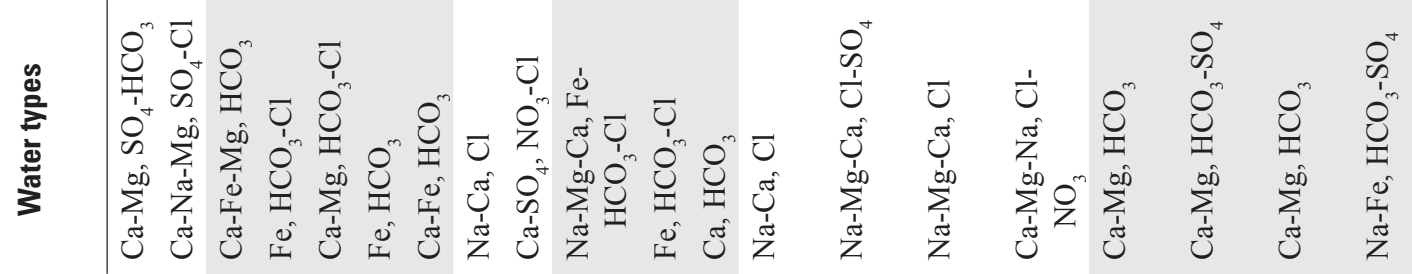

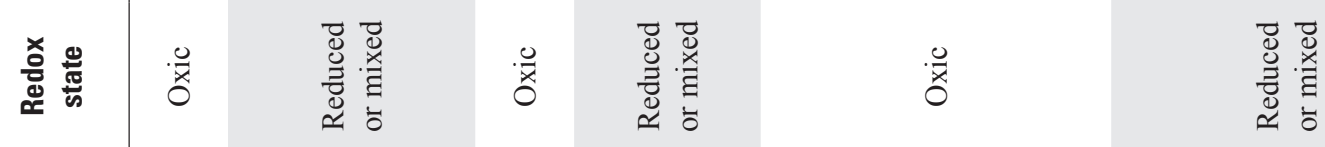

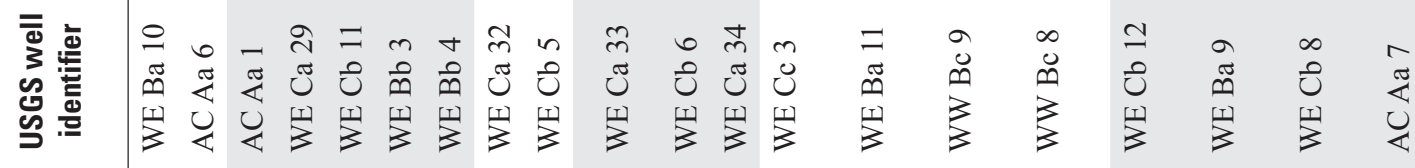

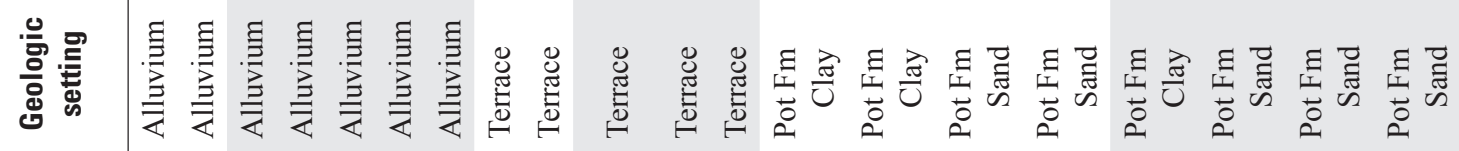




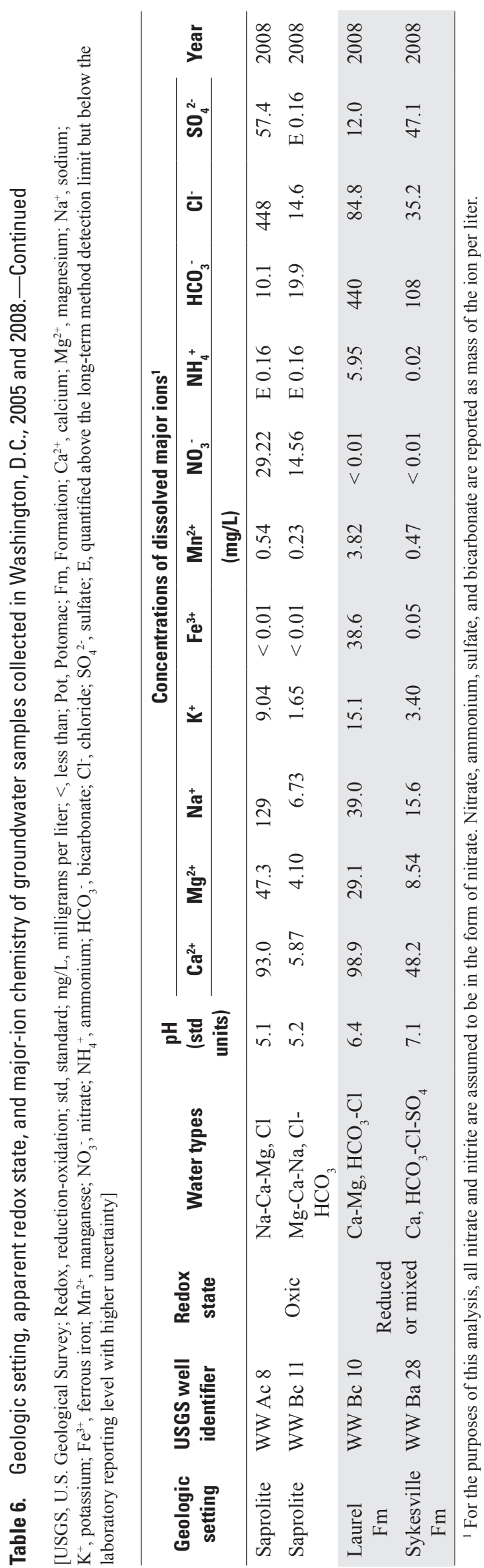




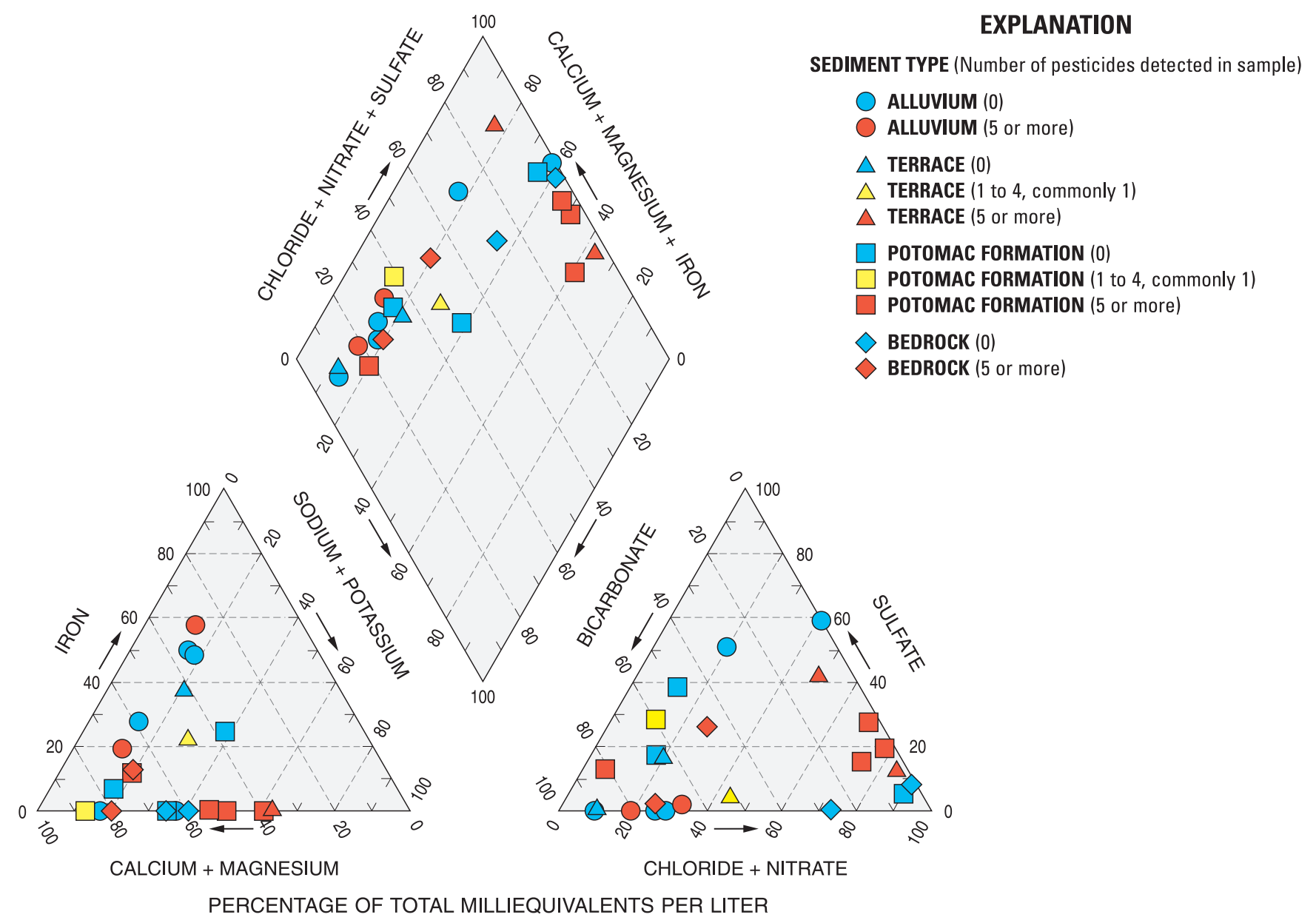

Figure 11. Trilinear diagrams showing pesticides in groundwater samples in relation to variations in the major-ion chemistry of groundwater associated with geologic units and sediments, lower Anacostia River and Rock Creek watersheds, Washington, D.C., 2005 and 2008.

sediments is that these wells are located in shallow outcrop and subcrop parts of this formation, where permeable and impermeable sediments are often highly interbedded and discontinuous in nature.

Piedmont Saprolite and Fractured Rock (Laurel and Sykesville Formations) - Four Piedmont wells (fig. 1) were completed in saprolite (wells WW Ac 8 and WW Bc 11) or in fractured rock in the Laurel (well WW Bc 10) and Sykesville (WW Ba 28) Formations (table 4). The land area in the vicinity of these wells was 33 to 81 percent developed. Except for well WW Ba 28, the wells were completed in unconsolidated materials, with the tops of the screened intervals within approximately 22 to $28 \mathrm{ft}$ of land surface. Well WW Ba 28 was screened in bedrock from 50 to $100 \mathrm{ft}$ below land surface. The saprolite wells had either a sandy (WW Ac 8) or silty clay (well WW Bc 11) overburden throughout. The overburden for well WW Bc 11 consisted of silty sand with thick silt and clay layers; and for well WW Bc 10, the unconsolidated overburden was saprolite with silty sand and a thick silty clay layer.

Groundwater chemistry differed among the four well sites (fig. 11) and appeared to depend on a combination of sediment permeability, and anthropogenic effects. Groundwater samples from the two Piedmont saprolite wells were very different from each other. The groundwater sample from well WW Ac 8 , which has a sandy overburden, contained high concentrations of calcium and magnesium, elevated concentrations of sodium $(>128 \mathrm{mg} / \mathrm{L})$, nitrate $(>29 \mathrm{mg} / \mathrm{L})$, chloride $(>480$ $\mathrm{mg} / \mathrm{L})$, and sulfate $(>57 \mathrm{mg} / \mathrm{L})$, and five detections of pesticide compounds. The groundwater sample from well WW Bc 11 (which has a silty clay overburden, table 4 ) had an elevated concentration of nitrate ( $>14 \mathrm{mg} / \mathrm{L}$ ), low concentrations of calcium, magnesium, and sodium, and no detectable pesticides.

Groundwater from the wells completed in the Laurel and Sykesville Formations, which both have thick silt, clay, or silty clay layers in the overburden, appeared to reflect reduced or mixed redox conditions, being slightly acidic to neutral in $\mathrm{pH}$ (6.7 to 7.1), with no measureable nitrate, but otherwise possibly affected by anthropogenic inputs. The chemistry of groundwater at well WW Bc 10 (table 6) indicated a calciumbicarbonate type water that contained elevated concentrations of ammonium $(>5 \mathrm{mg} / \mathrm{L})$, chloride $(>84 \mathrm{mg} / \mathrm{L})$ and possibly sulfate $(12 \mathrm{mg} / \mathrm{L})$. Groundwater from well WW Ba 28 also 


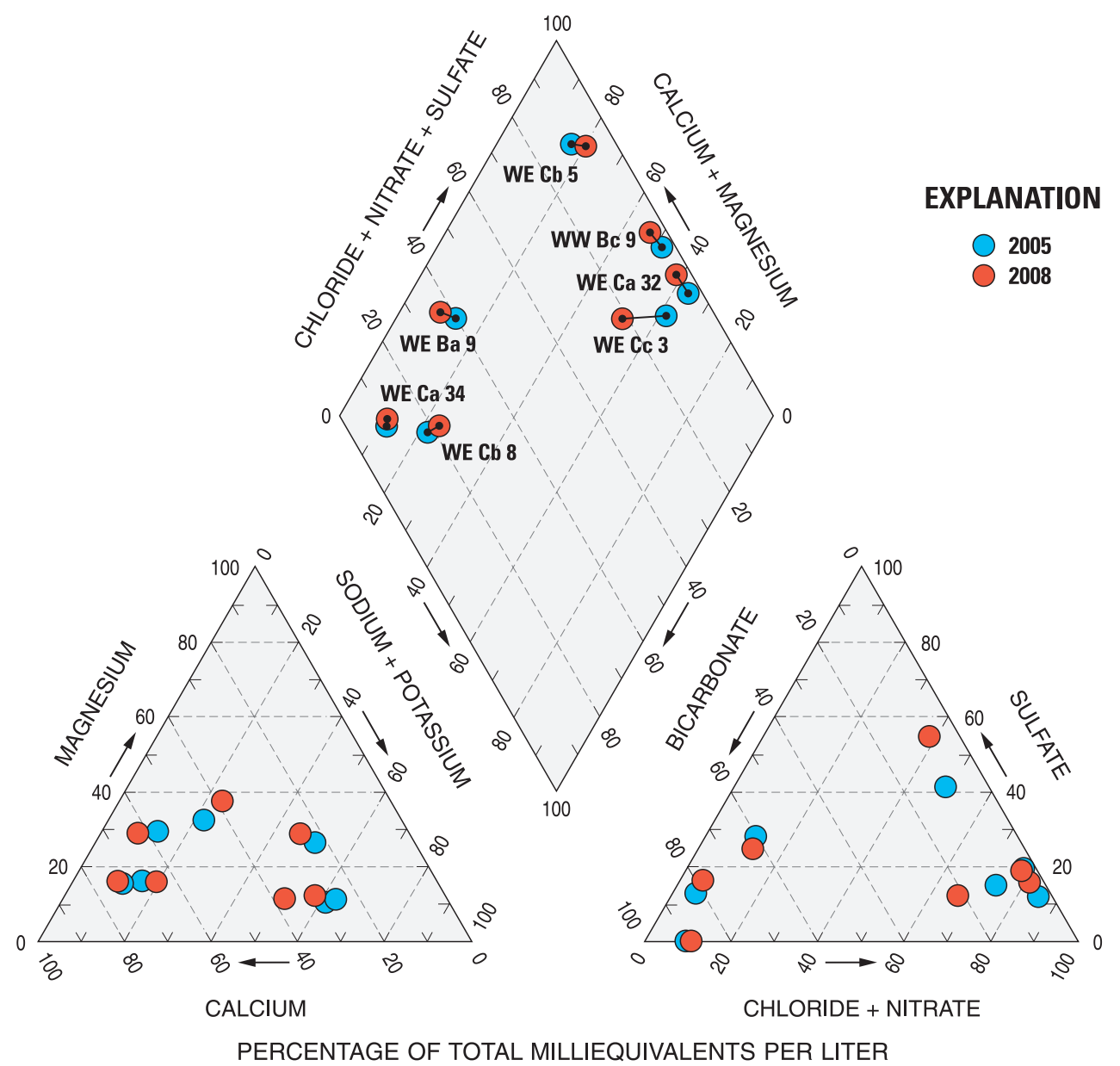

Figure 12. Trilinear diagrams showing changes in major-ion chemistry in groundwater samples collected from seven wells in the lower Anacostia River and Rock Creek watersheds, Washington, D.C., 2005 and 2008.

was calcium-bicarbonate type water, but with low concentrations for most dissolved cations, no measurable nitrate, and little ammonium, but elevated concentrations of chloride $(>35 \mathrm{mg} / \mathrm{L})$ and sulfate $(>47 \mathrm{mg} / \mathrm{L})$. Groundwater samples from both wells, however, contained no detectable pesticides.

The groundwater chemistry for all four wells in the Piedmont regardless of redox condition indicated some vulnerability to groundwater contamination. Only the groundwater sample from well WW Ac 8 with a sandy overburden had detectable pesticides. The fact that no pesticides were detected in groundwater samples from the other three Piedmont wells could be due in part to the low permeability and predominantly silty or silty clay overburden materials that occur at each well site. These layers could have physically limited the rate of vertical groundwater flow and thus pesticide transport at depth, or enhanced pesticide adsorption and degradation.

The lack of pesticide detections in groundwater samples from two Piedmont wells also could have been due in part to land use. Only 33 percent and 49 percent of the land in the vicinity of wells WW Ba 28 and WW Bc 11, respectively, was developed (table 4). Approximately 80 percent of the land within the vicinity of wells WW Bc 10 and WW Ac 8 was developed.

Differences in data-collection methods between 2005 and 2008 were not likely influential in relating groundwater chemistry to pesticide detections for wells completed in the Piedmont areas.

Although differences in data collection in relation to wells and analytical methods used in 2005 compared to 2008 possibly could have affected the determination of a relation between the presence of pesticides in groundwater and the chemistry of groundwater, mixtures of five or more pesticides generally occurred in shallow groundwater in or beneath generally permeable sediments and under oxic conditions as evidenced by the co-occurrence of elevated concentrations of other mostly anthropogenic contaminants-sodium, nitrate, chloride, and sulfate. With a few exceptions, mixtures of pesticides were not detected in reduced groundwater, or mixtures of oxic and reducing groundwater, in or beneath generally impermeable sediments or sediments that clearly contained relatively thick silt or silty clay, or clay layers. Groundwater at selected locations in most of the geologic units studied that 
exhibited other than oxic conditions also exhibited elevated concentrations of ammonium, chloride, sodium, nitrate, chloride, and (or) sulfate, but few if any pesticides. The absence of pesticides, however, could reflect a physical impediment to the rate of vertical groundwater flow and thus transport of contaminated groundwater that contained pesticides through these sediments or the adsorption and degradation of pesticides as contaminated groundwater moved through these sediments.

For selected surficial geologic units, the presence or absence of relatively impermeable sediments was consistent enough among sites within the formation to possibly indicate the vulnerability of shallow groundwater in the formation to pesticide contamination. For example, groundwater obtained from wells completed in the Holocene alluvium and Piedmont saprolite (silt and silty clay materials), was least likely to contain multiple pesticides. Groundwater from terrace deposits which often contain abundant sand and (or) silty sand, was most likely to have pesticides present. Wells completed in the Potomac Formation outcrop or subcrop areas were the most difficult to characterize due to the apparent interbedded and discontinuous nature of permeable and impermeable sediments.

\section{Variability of Precipitation}

The transport of soluble pesticides to and within the shallow surficial aquifer is dependent upon groundwater recharge and flow, respectively. Therefore, differences in pesticide detections in groundwater samples collected in 2005 compared to 2008 were examined in relation to possible variations in precipitation and thus potential recharge during the period of data collection.

For the purposes of this report, precipitation and streamflow are summarized from 2004 through 2008. Climatic data indicate the annual precipitation and streamflow for most of the period from 2004 through 2008 were higher than average, with only 2007 being a below-average year (table 7).

Table 7. Precipitation and streamflow in the Washington, D.C. greater metropolitan area, 2004 through 2008.

[NOAA, National Oceanic and Atmospheric Administration; USGS, U.S. Geological Survey; MD, Maryland; ft³/s; cubic feet per second; water years are defined as the period from October through September]

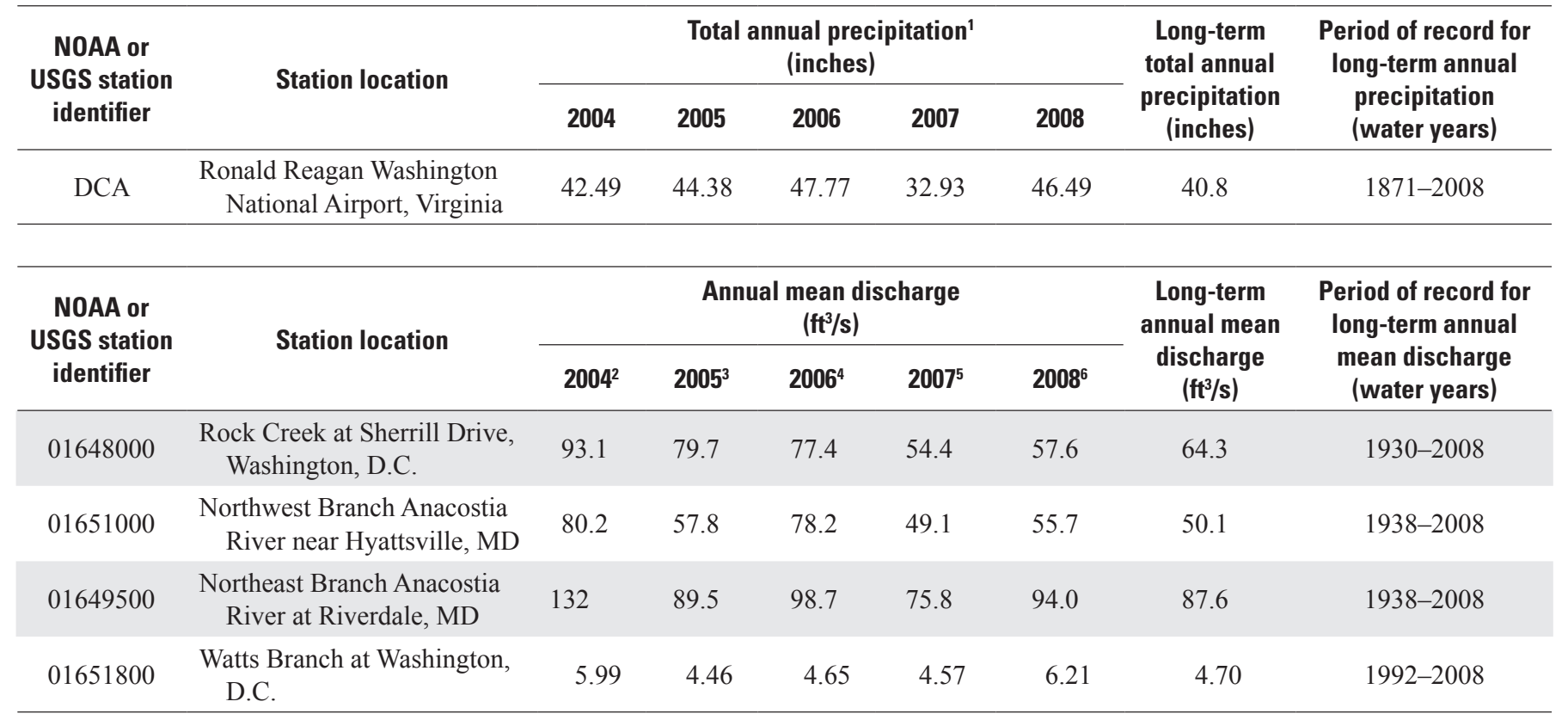

${ }^{1}$ National Oceanic and Atmospheric Administration (NOAA), 2010.

Streamflow data from U.S. Geological Survey Annual Data Reports:

${ }^{2}$ Saffer and others, 2005.

${ }^{3}$ Saffer and others, 2006.

${ }^{4}$ U.S. Geological Survey, 2007.

${ }^{5}$ U.S. Geological Survey, 2008.

${ }^{6}$ U.S. Geological Survey, 2009. 
The relatively wet period from 2004 through 2008 enhanced recharge in the study area. The effects of enhanced recharge on the mobility and transport of pesticides in 2005 or 2008 were not determined in this study.

Changes in inorganic chemical composition of groundwater from 2005 to 2008 at most well locations were relatively small (fig. 12), and reflected only minor increases or decreases in the concentrations of individual ions (table 8). Although these changes could be related to changes in groundwater recharge, they are not entirely consistent with the previous discussion relating pesticide detections and the inorganic chemistry of groundwater at these sites. Specifically, increases in pesticide detections in groundwater at a site were not necessarily accompanied by the expected increases in the concentrations of other indicators of anthropogenic contamination, for example, nitrogen, chloride, and (or) sulfate, that one could anticipate given the redox condition at that site. Furthermore, the differences in pesticide detections between years due to differences in the number and type of laboratory methods used confounds the interpretation of the possible effect of climate on pesticide detections between years.
For example, in the case of well WE Cb 5, one pesticide was present in the groundwater sample collected in 2005, and five pesticides were present in the groundwater sample collected in 2008. Given that this well was completed in a terrace deposit and groundwater appears oxic, one might have expected the change in the number of pesticides to coincide with an increase in the concentrations of chloride and sulfate. However, of the five pesticides detected in groundwater in 2008 , two (prometon and simazine) were not in the analytical schedules used in the analysis of groundwater samples in 2005. In addition, CIAT was detected in the groundwater sample in 2008, but at a concentration below the 2005 reporting level of $0.03 \mu \mathrm{g} / \mathrm{L}$.

Artifacts occur for other wells also. Well WE Cb 8 had a marked increase from one to eight pesticide detections from 2005 to 2008. The presence of oxic groundwater and declines in the concentrations of most inorganic constituents from 2005 to 2008 likely reflect artificial recharge from a nearby leaking fire hydrant, rather than an increase in natural recharge (appendix B).

Table 8. Major-ion composition of groundwater samples, 2005 and 2008.

[USGS, U.S. Geological Survey; mg/L, milligrams per liter; <, less than; std, standard; E, estimated; $\mathrm{Na}^{+}$, sodium; $\mathrm{K}^{+}$, potassium; $\mathrm{Mg}^{2+}$, magnesium; $\mathrm{Ca}^{2+}$, calcium; Mn, manganese; Fe, iron; $\mathrm{NH}_{4}^{+}$, ammonium; $\mathrm{Cl}^{-}$, chloride; $\mathrm{SO}_{4}^{2-}$, sulfate; $\mathrm{NO}_{3}^{-}$, nitrate; $\mathrm{HCO}_{3}^{-}$, bicarbonate]

\begin{tabular}{|c|c|c|c|c|c|c|c|c|c|c|c|c|c|}
\hline \multirow{2}{*}{$\begin{array}{c}\text { USGS } \\
\text { well } \\
\text { identifier }\end{array}$} & \multirow{2}{*}{$\begin{array}{c}\text { Year of } \\
\text { sample } \\
\text { collection }\end{array}$} & \multirow{2}{*}{$\begin{array}{c}\text { pH } \\
\text { (std } \\
\text { units) }\end{array}$} & \multicolumn{11}{|c|}{ Concentrations of dissolved major ions ${ }^{1}$} \\
\hline & & & \multicolumn{11}{|c|}{$(\mathrm{mg} / \mathrm{L})$} \\
\hline \multirow{2}{*}{ WE Ba 9} & 2005 & 6.2 & 11.7 & 5.12 & 25.9 & 91.7 & 0.55 & $<0.01$ & 0.31 & 24.2 & 81.1 & 6.02 & 260 \\
\hline & 2008 & 6.1 & 15.3 & 5.31 & 22.2 & 71.3 & 0.97 & $<0.01$ & 0.70 & 25.8 & 85.1 & 0.58 & 230 \\
\hline WE Ca 32 & 2005 & 5.6 & 122 & 7.73 & 14.3 & 57.4 & $<0.01$ & 0.01 & $<0.05$ & 257 & 79.7 & 34.26 & 21.0 \\
\hline \multirow{2}{*}{ WE Ca 34} & 2005 & 7.3 & 13.9 & 6.72 & 13.8 & 103 & 0.64 & 7.93 & 3.75 & 27.6 & 0.10 & $<0.03$ & 386 \\
\hline & 2008 & 7.4 & 16.6 & 6.64 & 14.2 & 109 & 0.58 & 3.14 & 2.13 & 27.1 & 1.36 & $<0.01$ & 435 \\
\hline \multirow{2}{*}{ WE $\mathrm{Cb} 8$} & 2005 & 6.8 & 4.72 & 5.53 & 6.63 & 11.2 & 0.19 & 3.07 & 0.07 & 2.91 & 11.8 & $<0.03$ & 70.6 \\
\hline & 2008 & 6.8 & 2.20 & 4.35 & 3.71 & 8.50 & 0.16 & 3.49 & 0.41 & 1.98 & 6.24 & $<0.01$ & 49.7 \\
\hline WE Cc 3 & 2008 & 5.8 & 95.8 & 3.70 & 9.04 & 40.0 & 0.15 & $<0.01$ & $<0.02$ & 185 & 55.2 & 12.84 & 52.1 \\
\hline \multirow{2}{*}{ WW Bc 9} & 2005 & 4.8 & 30.1 & 4.52 & 10.9 & 15.6 & 0.30 & 0.01 & $<0.05$ & 77.3 & 30.6 & 12.93 & 7.40 \\
\hline & 2008 & 4.7 & 34.7 & 4.52 & 10.3 & 14.8 & 0.28 & $<0.01$ & $<0.02$ & 79.8 & 31.2 & 12.22 & 5.80 \\
\hline
\end{tabular}

${ }^{1}$ For the purposes of this analysis, all nitrate and nitrite are assumed to be in the form of nitrate. Nitrate, ammonium, sulfate, and bicarbonate are reported as mass of the ion per liter. 


\section{Summary and Conclusions}

The U.S. Geological Survey (USGS), in cooperation with the District Department of the Environment (DDOE), conducted a groundwater-quality investigation in 2005 and 2008 to assess groundwater in the surficial aquifers of the Anacostia River and Rock Creek watersheds in Washington, D.C. The area was investigated to (a) determine the types, presence, concentrations, and distribution of selected pesticides; and (b) assess pesticide presence in relation to selected land-use and hydrogeologic characteristics. Data and information for this investigation were obtained from 2001 land-use data layers, well drilling logs, and groundwater samples collected in 2005 and 2008. In 2005, 17 monitoring wells were completed in the surficial aquifers with locations selected to target representative geologic units and land use, and were located chiefly in parks or other accessible settings. Similar data and information were obtained in 2008 from seven of the wells sampled in 2005, as well as seven additional monitoring wells located in similar land-use settings.

The groundwater samples collected in 2005 and 2008 were analyzed for pesticides, major ions, nutrients, and selected trace elements that may reflect the effects of human (urban) activities or natural processes on the chemistry of shallow groundwater. Quality-control (QC) samples, including field blanks and duplicate groundwater samples were concurrently collected with groundwater samples at two or more different well sites and analyzed with the groundwater samples during each year of data collection. Additional QC data associated with the analysis of pesticide samples were obtained from the USGS National Water Quality Laboratory in Denver, Colorado, and the USGS Organic Chemistry Research Laboratory in Lawrence, Kansas.

For the purposes of data interpretation, results from an analysis of the QC data from field blanks and duplicate groundwater samples indicated that the quality of groundwater data in 2005 and 2008 was similar, and that data from both years were suitable for combining and interpreting. Results from comparisons of the pesticide groundwater and laboratory QC data obtained from the seven wells used in both 2005 and 2008 indicated that (a) enhanced method performance and the addition of compounds to the USGS laboratory methods used in 2005, and (b) inclusion of an additional USGS laboratory method for polar pesticides in 2008, led to an increase in the types and numbers of pesticides detected in groundwater samples obtained in 2008 compared to groundwater samples obtained from the same wells in 2005. Therefore, the interpretation of the pesticide data chiefly was made by year of collection. Interpretation of combined data from both years was limited to basic descriptions of the types of pesticides detected and discussions of the presence or absence of pesticides in groundwater in relation to different land-use and hydrogeologic features.

\section{Pesticide Types and Frequencies of Detection}

Groundwater samples were analyzed for more than 75 different individual parent or degradate pesticide compounds, including those compounds of concern to DDOE and either suspected or known to occur in urban groundwater. Twentyseven different parent or degradate compounds, representing at least 19 unique herbicides and insecticides, were detected in groundwater samples collected from the surficial aquifer in Washington, D.C. in 2005 and 2008. No fungicides were detected in any groundwater samples collected in either 2005 or 2008. General findings related to the types of compounds detected are:

a. The pesticide compounds detected were herbicides commonly used in urban settings for non-specific weed (broadleaf or grass) control-for example, the $s$-triazines (atrazine, prometon, simazine) and chloroacetanilides (metolachlor and alachlor) - and several different types of insecticides for nonspecific haustellate (sucking) insects or termite control-for example, diuron; chlorpyrifos; imidacloprid; fipronil; p,p'-DDT; chlordane; and heptachlor.

b. Detected parent or degradate compounds were pesticides (1) generally still in use, for example, the $s$-triazines; (2) no longer in use, or whose use has been highly restricted, for example, dieldrin, chlordane, heptachlor, and p,p'-DDT; or (3) whose use has replaced banned or restricted pesticides, for example, fipronil, in place of dieldrin, chlordane, and heptachlor.

c. For those pesticides for which degradate analyses were conducted — $s$-triazines; diuron; glyphosate; p,p'-DDT; heptachlor; and fipronil - the degradate compounds were at least as likely to be detected in groundwater than the parent compounds.

On the basis of frequency of detections and types of pesticides found, groundwater in the surficial aquifer (within 100 feet of land surface) in the Anacostia River and Rock Creek watersheds in Washington, D.C. appeared susceptible to pesticide contamination. In 2008, at least one herbicide or insecticide was detected in the groundwater samples collected from 61 percent of the study sites. Multiple pesticides were quite likely to be detected in groundwater that contained at least one pesticide. Five or more different pesticides were detected in groundwater samples collected from 88 percent of the study sites, and 15 different pesticide compounds were detected in groundwater at one site (well WE Ca 32).

The most frequently detected pesticides in 2008 were the herbicides atrazine, simazine, and prometon, and the atrazine degradates CIAT, CEAT, and OIET. At least one or more of these compounds was detected in groundwater at eight different study sites. Acetachlor and metolachlor were the next most frequently detected herbicides, and one or both of these compounds were found in groundwater at four different 
sites. Ureic herbicides were found in various combinations in groundwater from three different sites. Bromacil was detected in groundwater from two sites; diuron, a degradate compound (3,4-Dichloroaniline), and tebuthiuron, were detected along with bromacil at one of the above sites; and fluometuron and sulfometuron methyl were detected in groundwater from the third site. The organophosphate herbicide glyphosate was detected in groundwater from one site, and its degradate AMPA in groundwater from another site.

Insecticide and insecticide-degradate residues also were detected in groundwater samples collected in 2008 but less frequently than herbicides. Two to six different parent and (or) degradate compounds of insecticides were present in groundwater from five different sites. The frequencies of detections were fairly evenly distributed among several different types of insecticides, which included chlorpyrifos; p,p'-DDD; dieldrin; chlordane; heptachlor epoxide; fipronil; and the sulfide and sulfone degradates of fipronil.

Because of the previously noted differences in the analytical capabilities between years, fewer pesticides were detected in groundwater in the surficial aquifer in 2005 than in 2008. Nevertheless, in 2005 at least one herbicide or insecticide was detected in groundwater from 50 percent of the study sites. Although a variety of pesticides were detected in the shallow groundwater in 2005 and 2008, maximum concentrations for any parent or degradate compound were no greater than a few tenths of a microgram per liter $(\mu \mathrm{g} / \mathrm{L})$, and, for most detected compounds, concentrations were less than $0.1 \mu \mathrm{g} / \mathrm{L}$. For many of the compounds, the detected concentration was below the laboratory reporting level but above the laboratory detection level; therefore, the concentration is reported as estimated (coded with an "E") with a greater than normal uncertainty.

\section{Pesticide Concentrations and Human and Aquatic Health}

Human and aquatic health assessments were conducted on the types and concentrations of pesticides detected in groundwater. Assessment criteria were selected to provide guidance on most of the frequently detected compounds. For human health, three assessment criteria or guidelines were used- the U.S. Environmental Protection Agency (USEPA) Maximum Contaminant Level (MCL) for drinking water, the USEPA recommended criteria for the consumption of freshwater, and the non-regulatory and USEPA-approved USGS health-based assessment benchmarks. For aquatic health, three assessment guidelines also were used - the USEPA long-term chronic-exposure continuous concentration, the U.S. Great Lakes aquatic-health objectives, and the Canadian Council of Ministers of the Environment (CCME) guidelines for the protection of aquatic health.

Except for several banned insecticides that are resistant to degradation, no other pesticides were found in 2005 or 2008 at any study site at a concentration that exceeded any of the three human-health standards. At a few sites and during both years of sampling, groundwater concentrations exceeded the USEPA recommended criteria for the consumption of freshwater for p,p'-DDD; p,p'-DDE; dieldrin; heptachlor epoxide; and chlordane. Concentrations of dieldrin also exceeded the USGS health-based assessment benchmark for this compound at several sites.

The same legacy compounds were responsible for most exceedances of aquatic-health guidelines. At several wells and in both years, groundwater concentrations of heptachlor epoxide; p,p'-DDE; p,p'-DDD; dieldrin; and chlordane exceeded the USEPA long-term chronic-exposure concentrations for each of these compounds. U.S. Great Lakes objectives were exceeded for dieldrin and p,p'-DDE at several sites in both years, and the CCME guidelines for the protection of aquatic health were exceeded for chlorpyrifos at one site in 2008.

The concentrations of the pesticide compounds that exceeded either a human or aquatic action level were low, and in some cases the concentrations were estimated (with a higher than normal uncertainty). However, no human- or aquatichealth standards existed for some of the parent compounds or for most of the degradates, including some of the most frequently detected chemicals. Neither human- or aquatichealth standards had been established for mixtures of different pesticides that were observed in groundwater in 2005 and 2008 from the majority of study sites.

\section{Comparison of Pesticide Occurrence with Studies in the Nearby Coastal Plain and Piedmont}

In many respects, the occurrence of pesticides in shallow groundwater in the Coastal Plain and Piedmont Physiographic Provinces within Washington, D.C. mirrored regional patterns found in shallow groundwater in similar physiography adjacent to Washington, D.C. Findings from two other studies, one in the Coastal Plain and another in the Piedmont, in particular, were similar to the findings in the current study:

a. Both of the other studies found many of the same types of herbicides and insecticides as were found in this study, and at similarly low concentrations (often less than $0.1 \mu \mathrm{g} / \mathrm{L})$.

b. Both studies found, as in this study, that the most frequently detected herbicides in shallow groundwater chiefly were the $s$-triazines, alachlor, and metolachlor, and their degradate compounds.

c. Both studies found, as in the current study, a relatively high frequency of sites that yielded groundwater with pesticide-residue mixtures. In the Coastal Plain study, groundwater from many of the wells had 5 or more detectable pesticide residues, and groundwater from one well contained 11 different pesticides. In the Maryland-Virginia Piedmont study, 73 percent of the wells yielded groundwater samples that contained mix- 
tures of 5 or more pesticide compounds, and groundwater from one well contained 27 different pesticide residues.

d. Both studies, as in the current study, identified degradation-resistant legacy insecticides as pesticides of concern in relation to the USGS health-based assessment benchmarks for shallow groundwater.

\section{Land Use and Hydrogeologic Factors Related to Pesticide Occurrence}

The presence of pesticides in shallow groundwater in Washington, D.C. appears to be related to land use and hydrogeologic factors that in turn reflect the use and subsequent mobility of pesticides. The relative amounts of developed (residential or commercial) space and open (water, forest, grassland, or other low-maintenance) space within 500 meters of a well were used as surrogates for pesticide use. In 2008, multiple pesticide detections in groundwater were chiefly associated with wells with at least 50 percent, and most commonly 60 percent or more, of the surrounding area under development. Insecticides in particular were detected in groundwater associated with wells whose surrounding area was at least 50 percent, and commonly at least 80 percent, developed. The site associated with the highest number of pesticide detections (well WE Ca 32, eight herbicide and seven insecticide compounds) was in an area with 99 percent development.

However, hydrogeologic setting also plays a role in whether pesticides are detected in groundwater. Although data were insufficient to conduct a rigorous statistical analysis, three hydrogeologic factors appeared to have some bearing on the presence of pesticides in shallow groundwater - the depth of the well within the aquifer, the type of surficial sediment in which the well was completed or that overlies the screened interval of the well, and the chemistry of groundwater.

Pesticide occurrence appeared to be inversely related to the depth of the well in the surficial aquifer, which presumably relates to the age of groundwater from its time of recharge. Pesticides chiefly occurred in groundwater samples collected from wells in 2005 and 2008 that were completed at shallow depths -28 feet or less below land surface to the top of the well screen. This could indicate that groundwater that contains pesticide residues had not fully penetrated the surficial aquifer in all geologic settings, which on the basis of wells used, extends to a depth of at least 50 feet below land surface.

The presence of pesticides in groundwater was examined in relation to major types of surficial material, including: (a) alluvium and terrace deposits, (b) sediments classified as sand or clay lithofacies in shallow outcrop and subcrop areas of the Potomac Formation in the Coastal Plain, (c) Piedmont saprolite, and (d) Piedmont fractured bedrock beneath the saprolite (Sykesville and Laurel Formations). Examination of the presence of mixtures of five or more pesticides in groundwater within each of these surficial aquifers indicated groundwater pesticide contamination is less a function of the general classification of bedrock, and more a function of the overlying materials that can affect the rate of groundwater flow, the groundwater chemistry, and ultimately pesticide mobility.

Mixtures of five or more pesticides in groundwater generally were linked to two conditions: (a) wells that were completed in generally permeable sediments, as evidenced by the absence in drilling logs of any description of silt, silty clay, or clay layers 10 or more feet thick; and (b) groundwater associated with oxic conditions, elevated concentrations of some possibly anthropogenic indicators - sodium, nitrate, chloride, and (or) sulfate, and low to no measureable concentrations of iron. With a few exceptions, mixtures of pesticides were not detected in or beneath materials with low permeability, such as thick silt, silty clay, or clay layers, or at sites with reducing groundwater.

The absence of measureable pesticides in groundwater in or beneath low-permeability sediments and under reducing or mixed redox conditions could reflect settings with reduced rates of vertical groundwater flow that slow the transport of pesticide-contaminated groundwater deeper into the surficial aquifer. It could also be that in such settings, pesticides are adsorbed and degraded as contaminated groundwater moves through the surficial aquifer. Some combination of both of these processes might explain why pesticides generally did not appear throughout the surficial aquifer.

The role of sediment permeability as a factor in pesticide transport in the surficial aquifer can be extrapolated to provide some indication of the vulnerability of groundwater to pesticide contamination in each type of surficial material described earlier. No pesticides were detected in wells completed in the Coastal Plain alluvium, nor in wells completed in the Piedmont fractured bedrock. Wells in these locations were completed below thick layers of low-permeability silt, silty-clay, or clay materials in beds ten or more feet thick, and groundwater reflected either a reduced state or mixed redox conditions. Groundwater from terrace deposits, which often contain abundant sand and (or) silty sand, was most likely to contain pesticide mixtures. Groundwater chemistry in wells completed in the Potomac Formation outcrop or subcrop areas was the most difficult to characterize due to the apparent interbedded and discontinuous nature of permeable and impermeable sediments.

The preceding analysis of the relation between the presence of pesticides in shallow groundwater and sediment permeability and groundwater chemistry was conducted with data from 2005 and 2008, and under the assumption that groundwater chemistry did not markedly change from 2005 to 2008. To address this assumption, annual precipitation and streamflow were evaluated from 2004 to 2008 and both climate indicators were found to be above average in 4 of the 5 years. Due to differences in analytical methods, however, it was not possible to determine if there were differences in the occurrence of pesticides between 2005 and 2008 . 


\section{Comparison with Regional Groundwater Studies: Pesticide Occurrence and Land Use and Hydrogeologic Settings}

The presence of pesticides in shallow groundwater in the surficial aquifer as a function of developed lands, depths, permeable and oxic environments, and the co-occurrence of other chemical indicators in groundwater contamination from human activities mirrored regional patterns found by other studies on shallow groundwater in the Coastal Plain and the Piedmont surficial aquifers near Washington, D.C. Patterns in land use in the Coastal Plain have frequently been used as surrogates for pesticide use and have related pesticide occurrence and distribution in groundwater to agricultural and urban development. From a regional perspective, pesticide concentrations in groundwater generally decline with depth in the surficial aquifer, and groundwater that contains pesticides likely reflects recently recharged water that is relatively young (post-1940s or 1950s). As is the case in the current study, previously conducted Coastal Plain studies have indicated the highest frequency of occurrence of pesticides in groundwater were linked to areas with permeable sediments and oxic conditions, and when pesticides were detected in groundwater, other anthropogenic contaminants were found as well. Co-contaminants included elevated concentrations of nutrients, and in particular, nitrogen, which possibly was associated with the disposal and transport of human sewage, the disposal or use of domestic animal wastes (as manure), and the use of fertilizers for crops or residential lawns and gardens. In Washington, D.C., nitrogen in the form of nitrate or ammonium was a major co-contaminant with pesticides in groundwater.

\section{Acknowledgments}

The authors would like to thank the District Department of the Environment for support of this study. The U.S. National Park Service and the Washington, D.C. Department of Parks and Recreation are thanked for their cooperation and permission to install monitoring wells on their respective properties. Review comments from the following U.S. Geological Survey (USGS) colleagues also were greatly appreciated: Linda Debrewer, Hydrologist, Reston, Virginia; and Connie Loper, Hydrologist, Pennsylvania Water Science Center, Harrisburg, Pennsylvania. The authors would also like to thank the USGS personnel from the MD-DC-DE Water Science Center who contributed to the preparation, collection, and processing of the analytical samples, especially Jessica Teunis, David Brower, and Wendy McPherson.

\section{References Cited}

Anacostia Watershed Toxics Alliance, 2001, Charting a course toward restoration: A toxic chemical strategy for the Anacostia River, Washington, D.C.: Washington, D.C., Metropolitan Council of Governments, 103 p.

Anderson, A.L., Miller, C.V., Olsen, L.D., Doheny, E.J., and Phelan, D.J., 2002, Water quality, sediment quality, and stream-classification of Rock Creek, Washington, D.C., 1999-2000: U.S. Geological Survey Water-Resources Investigations Report 02-4067, 91 p.

Andrews, W.J., Fong, A.L., Harrod, L., and Dittes, M.E., 1998, Water-quality assessment of part of the Upper Mississippi River Basin, Minnesota and Wisconsin-Ground water quality in an urban part of the Twin Cities metropolitan area, Minnesota, 1996: U.S. Geological Survey WaterResources Investigations Report 97-4248, 54 p.

Ator, S.W., 2008, Natural and human influences on water quality in a shallow regional unconsolidated aquifer, Northern Atlantic Coastal Plain: U.S. Geological Survey Scientific Investigations Report 2008-5190, 19 p.

Ator, S.W., and Denis, J.M., 1997, Relation of nitrogen and phosphorus in ground water to land use in four subunits of the Potomac River Basin: U.S. Geological Survey WaterResources Investigations Report 96-4268, 26 p.

Banks, W.S.L., and Reyes, B., 2009, Anthropogenic organic compounds in source and finished groundwater of community water systems in the Piedmont Physiographic Province, Potomac River Basin, Maryland and Virginia, 2003-04: U.S. Geological Survey Scientific Investigations Report 2009-5064, 33 p.

Barbash, J.E., and Resek, E.A., 1996, Pesticides in groundwater: Distribution, trends, and governing factors: Chelsea, Michigan, Ann Arbor Press, 588 p.

Berndt, M.P., Galeone, D.R., Spruill, T.B., and Crandall, C.A., 1998, Ground-water quality in three urban areas in the coastal plain of the southeastern United States, 1995: U.S. Geological Survey Water-Resources Investigations Report 97-4234, 25 p.

Bruce, B.W., 1995, Denver's urban ground-water quality: Nutrients, pesticides, and volatile organic compounds: U.S. Geological Survey Fact Sheet FS-106-95, 2 p.

Canadian Council of Ministers of the Environment, 2007, Water-quality guidelines for the protection of aquatic life, Chap. 4: Summary table 7.1, 9 p., accessed March 8, 2010 at http://www.ccme.ca/assets/pdf/aql_summary_7.1_en.pdf. 
Chesapeake Bay Program, 2000, Appendix A: Fact Sheet on Chesapeake Bay Watershed Chemicals of Concern - as of September 26, 2000, 2 p., accessed March 8, 2010 at http:// www.chesapeakebay.net/content/publications/cbp_12210. $p d f$.

CH2M Hill, 1977, Rock Creek storm water and water-quality management study, prepared for the Montgomery County Planning Board: CH2M Hill, 409 p.

Debrewer, L.M., Ator, S.W., and Denver, J.M, 2007, Factors affecting spatial and temporal variability in nutrient pesticide concentrations in the surficial aquifer of the Delmarva Peninsula: U.S. Geological Survey Scientific Investigations Report 2005-5257, 44 p.

Denver, J.M., and Ator, S.W., 2006, Pesticides in ground water of the Maryland Coastal Plain: U.S. Geological Survey Fact Sheet 2006-3119, 8 p.

Desimone, L.A., Hamilton, P.A., and Gilliom, R.J., 2009, Quality of water from domestic wells in principal aquifers of the United States, 1991-2004-Overview of major findings: U.S. Geological Survey Circular 1332, 48 p.

District of Columbia, 1993, Water quality standards for groundwater, District of Columbia Municipal Regulations, Final rulemaking: (renumbered) 41 DCR 1075 (March 4, 1994) Title 21 DCMR, Chap. 11, sections 1150-1158 [variously paged].

District of Columbia, 2006, Water quality standards for surface waters, District of Columbia Municipal Regulations, Final rulemaking (February 15, 2006): Title 21 DCMR, chap. 11, sections 1100 to 1106,1158 , and 1199 [variously paged], accessed March 8, 2010 at http://ddoe.dc.gov/ddoe/frames. asp?doc $=/$ ddoe/lib/ddoe/wqd/WaterFinalRules06.pdf.

Flanagan, S.M., Montgomery, D.L., and Ayotte, J.D., 2001, Shallow ground-water quality in the Boston, Massachusetts metropolitan area: U.S. Geological Survey WaterResources Investigations Report 01-4042, 12 p.

Fleming, A.H., and Drake, A.A., Jr., and McCartan, L., 1998, Structure, age, and tectonic setting of a multiply reactivated shear zone in the Piedmont in Washington, D.C. and vicinity: Southeastern Geology, v. 37, no. 3, p. 115-140.

Focazio, M.J., Plummer, L.N., Böhlke, J.K., Busenberg, Eurybiades, Bachman, L.J., and Powars, D.S., 1998, Preliminary estimates of residence time and apparent ages of ground water in the Chesapeake Bay Watershed, and the water-quality data from a survey of springs: U.S. Geological Survey Water- Resources Investigations Report 97-4225, 75 p.
Focazio, M.J., Reilly, T.E., Rupert, M.G., and Helsel, D.R., 2002, Assessing ground-water vulnerability to contamination: Providing scientifically defensible information for decision makers: U.S. Geological Survey Circular 1224, 33 p.

Gilliom, R.J., Alley, W.M., and Gurtz, M.E., 1995, Design of the National Water Quality Assessment ProgramOccurrence and distribution of water-quality conditions: U.S. Geological Survey Circular 1112, 33 p.

Gilliom, R.J., Barbash, J.E., Crawford, C.G., Hamilton, P.A., Martin, J.D., Nakagaki, N., Nowell, L.H., Scott, J.C., Stackelberg, P.E., Thelin, G.P., and Wolock, D.M., 2006, Pesticides in the Nation's streams and ground water: U.S. Geological Survey Circular 1291, 172 p.

Hamilton, P.A., Denver, J.M., Phillips, P.J., and Shedlock, R.J., 1993, Water-quality assessment of the Delmarva Peninsula, Delaware, Maryland, Virginia - effects of agricultural activities on, and distribution of, nitrate and inorganic constituents, in the surficial aquifer: U.S Geological Survey Open-File Report 93-40, 87 p.

Helsel, D.R, and Hirsch, R.M., 2002, Statistical methods in water resources: U.S. Geological Survey Techniques of Water-Resources Investigations, book 4, chap. A3, Hydrologic Analysis and Interpretation, 524 p. (available at http://pubs.usgs.gov/twri/twri4a3/html/pdf_new.html).

Homer, C., Huang, C., Yang, L., Wylie, B., and Coan, M., 2004, Development of a 2001 national land cover database for the United States: Photogrammetric Engineering and Remote Sensing, v. 70, no. 7, p. 829-840.

International Joint Commission (Consolidator), U.S. and Canada, 1989, Revised Great Lakes Water Quality Agreement of 1978 as Amended by Protocol Signed November 18, 1987, Windsor, Ontario, Canada, accessed March 8, 2010 at http://www.ijc.org/en/activities/ consultations/glwqa/agreement.php.

Johnston, P.M., 1964, Geology and ground-water resources of Washington, D.C. and vicinity: U.S Geological Survey Water Supply Paper 1776, 97 p.

Kiely, T., Donaldson, D., and Grube, A., 2004, Pesticide industry usage and sales: 2000 and 2001 market estimates, Washington, D.C.: U.S. Environmental Protection Agency, Biological and Economic Analysis Division, Office of Pesticide Programs (7503C), 48 p.

Klohe, C.A., and Debrewer, L.M., 2007, Summary of groundwater-quality data in the Anacostia River Watershed, Washington, D.C., September-December, 2005: U.S. Geological Survey Open-File Report 2006-1392, 64 p. 
Kolpin, D.W., Squillace, P.J., Barbash, J.E., and Zogorski, J.S., 1997, Pesticides and volatile organic compounds in shallow urban groundwater of the United States, in Chilton, John and others, eds., Groundwater in the urban environment, v. 1, problems, processes, and management: Rotterdam, Netherlands, A.A. Balkema Publishers, p. 469-474.

Koterba, M.T., Banks, W.S.L., and Shedlock, R.J., 1993, Pesticides in shallow groundwater in the Delmarva Peninsula: Journal of Environmental Quality, v. 22, no. 3, p. 550-518.

Koterba, M.T., Wilde, F.D., and Lapham, W.W., 1995, Ground-water data-collection protocols and procedures for the National Water-Quality Assessment Program: Collection and documentation of water-quality samples and related data: U.S. Geological Survey Open-File Report 95-399, 113 p.

McCartan, L., 1989, Geologic map of Charles County, Maryland: Maryland Geological Survey County Geologic Map Series, scale 1:62,500.

Metropolitan Washington Council of Governments, 1998, Washington, D.C., Anacostia watershed restoration progress and conditions report, 1990-1997: Anacostia Watershed Restoration Committee Report, 44 p.

Metropolitan Washington Council of Governments, 2003, Working together to restore the Anacostia Watershed: Washington, D.C., Anacostia Watershed Restoration Committee, Annual Report, 20 p.

Miller, C.V., Gutiérrez-Magness, A.L., Feit-Majedi, B., and Foster, G.D., 2007, Water quality in the Upper Anacostia River, Maryland: Continuous and discrete monitoring with simulations to estimate concentrations and yields, 2003-05: U.S. Geological Survey Scientific Investigations Report 2007-5142, 51p.

Miller, C.V., and Klohe, C.A., 2003, Summary of waterand sediment-quality data for Anacostia River well sites sampled in July-August 2002: U.S. Geological Survey Open-File Report 03-73, 48 p.

National Oceanographic and Atmospheric Administration (NOAA), 2010, Precipitation data, accessed May 19, 2010 at http://www.erh.noaa.gov/lwx/climate/dca/dcaprecip.txt.

Phelan, D.J., and Miller, C.V., in press, Occurrence of organic wastewater compounds in Rock Creek Park, Washington, D.C., 2007-08: U.S. Geological Survey Scientific Investigations Report 2010-5162.
Pinkney, A.E., Harshberger, J.C., May, E.B., and Melancon, M.J., 2001, Tumor prevalence and biomarkers of exposure in brown bullhead (Ameiurus nebulosus) from the tidal Potomac River Watershed, USA: Environmental Toxicology and Chemistry, v. 20, no. 6, p. 1,196-1,205.

Pinkney, A.E., Harshberger, J.C., May, E.B., and Reichert, W.L., 2004, Tumor prevalence and biomarkers of exposure and response in brown bullhead (Ameiurus nebulosus) from the Anacostia River, Washington, D.C., and Tuckahoe River, Maryland, USA: Environmental Toxicology and Chemistry, v. 23, no. 3, p. 638-647.

Saffer, R.W., Pentz, R.H., and Tallman, A.J., 2005, Waterresources data for Maryland, Delaware, and Washington, D.C., Water Year 2004, v. 1, surface-water data, 540 p.

Saffer, R.W., Pentz, R.H., and Tallman, A.J., 2006, Waterresources data for Maryland, Delaware, and Washington, D.C., Water Year 2005, v. 1, surface-water data, 530 p.

Schneider, J., Montaser, A., and Watt, H.M., 1993, Ground water resource assessment study for the District of Columbia, Sampling and analysis report for the Group B wells_-Phase III: Washington, D.C. Water Resources Center Research Report No. 138, 24 p. plus appendix.

Schneider, J., O’Connor, J.V., Chang, F.M., Wade, C., Pao, H.P., Montaser, A., Johnson, J., and Atobrah, K., 1993, Ground water resource assessment study for the District of Columbia, Sampling and analysis report for the Group A wells_-Phase III: Washington, D.C., Water Resources Center Research Report No. 137, 31 p. plus appendix.

Shedlock, R.J., Denver, J.M., Hayes, M.A., Hamilton, P.A., Koterba, M.T., Bachman, L.J., Phillips, P.J., and Banks, W.S.L., 1999, Water-quality assessment of the Delmarva Peninsula, Delaware, Maryland, and Virginia: Results of investigations, 1987-91: U.S. Geological Survey WaterSupply Paper 2355-A, 41 p.

Shedlock, R.J., Hamilton, P.A., Denver, J.M., and Phillips, P.J., 1993, Multiscale approach to regional ground-waterquality assessment of the Delmarva Peninsula, in Alley, W.M., ed., Regional ground-water quality: New York, Van Nostrand Reinhold, p. 563-587.

Southworth, C. and Denenny, D., 2006, Geologic map of the National Parks in the National Capital region, Washington, D.C., Virginia, Maryland, and West Virginia: U.S. Geological Survey Open-File Report 2005-1331, 32 p.

Tenbus, F.J., 2003, Lithologic coring in the lower Anacostia tidal watershed, Washington, D.C., July 2002: U.S. Geological Survey Open-File Report 03-318, 62 p. 
The Trust for Public Land, 2009, City park facts 2009: San Francisco, California, Center for City Park Excellence, 32 p., accessed March 8, 2010 at http://www.tpl.org/ content_documents/CityParkFacts_2009.pdf.

Toccalino, P.L., 2007, Development and application of healthbased screening levels for use in water-quality assessments: U.S. Geological Survey Scientific Investigations Report 2007-5106, 12 p., accessed March 8, 2010 at http://pubs. usgs.gov/sir/2007/5106/pdf/sir20075106.pdf.

Toccalino, P.L., Norman, J.E., Phillips, R.H., Kaufmann, L.J., Stackelberg, P.E., Nowell, L.H., Krietman, S.J., and Post, G.B., 2004, Application of health-based screening levels to ground-water quality data in state-scale effort: U.S. Geological Survey Scientific Investigations Report 20055174, 64 p.

Tyler, T.D., and Belitz, K., 2009, Assigning land use to supply wells for the statistical characterization of regional groundwater quality: Correlating urban land use and VOC occurrence: Journal of Hydrology, v. 37, nos. 1-4, p. 100-108.

U.S. Census Bureau, 2008, Quickfacts: Washington, D.C., U.S. Census Bureau, accessed March 8, 2010 at http:// quickfacts.census.gov/qfd/states/11000.html.

U.S. Environmental Protection Agency, 1999, National recommended water-quality criteria: Washington, D.C., Office of Water, Office of Science and Technology Report 4304T, 22 p., accessed March 8, 2010 at http://www.epa.gov/ waterscience/criteria/wqctable/nrwqc-2009.pdf.

U.S. Environmental Protection Agency, 2004, 2004 Edition of the drinking water standards and health advisories: Washington, D.C. Office of Water, U.S. Environmental Protection Agency Report 822-R-04-005, 12 p., accessed March 8, 2010 at http://web.epa.ohio.gov/dsiwm/document/ newsPDFs/2004dwstandards.pdf.
U.S. Environmental Protection Agency, 2005, Fact Sheet: The drinking water contaminant candidate list-The source of priority contaminants for the Drinking Water Program: Washington, D.C., Office of Water, U.S. Environmental Protection Agency Report. No. EPA 815-F-05-001, 6 p., accessed March 8, 2010 at http://www.epa.gov/ogwdw/ccl/ $p d f_{s} / f_{s \_c c l 2}$ final-02-23-05.pdf.

U.S. Environmental Protection Agency, 2009, Drinking Water Standards and Health Advisories, 2009 Edition: Washington, D.C., Office of Water, U.S. Environmental Protection Agency Report No. 822-R-011, 12 p.

U.S. Geological Survey, 2007, Water-resources data for the United States, Water Year 2006, accessed May 19, 2010 at http://wdr.water.usgs.gov/wy2006/search.jsp.

U.S. Geological Survey, 2008, Water-resources data for the United States, Water Year 2006, accessed May 19, 2010 at http://wdr.water.usgs.gov/wy2007/search.jsp.

U.S. Geological Survey, 2009, Water-resources data for the United States, Water Year 2006, accessed May 19, 2010 at http://wdr.water.usgs.gov/wy2008/search.jsp.

Wheeler, J.C., 2003, Water withdrawal and use in Maryland, 1990-91: U.S. Geological Survey Water-Resources Investigations Report 93-4225, 42 p.

Williams, G.P., 1977, Washington, D.C.'s vanishing springs and waterways: U.S. Geological Survey Circular 752, 19 p.

Yorke, T.H., and Herb, W.J., 1978, Effects of urbanization on streamflow and sediment transport in the Rock Creek and Anacostia River Basins, Montgomery County, Maryland, 1962-74: U.S. Geological Survey Professional Paper 1003, $71 \mathrm{p}$. 


\section{Appendix A: Water-quality and quality-control data tables, 2008}

\section{Tables}

A1. Concentrations of major ions, nutrients, and pesticides in groundwater samples collected in Washington, D.C., August to September 2008, and selected water-quality standards.

A2. Description of quality-control samples obtained in conjunction with the collection of groundwater samples in Washington, D.C., August to September 2008. 
Table A1. Concentrations of major ions, nutrients, and pesticides in groundwater samples collected in the Anacostia River and Rock Creek watersheds in Washington, D.C., August to September 2008, and selected water-quality standards.

[CASRN ${ }^{\circledR}$, Chemical Abstracts Service Registry Number; USGS, U.S. Geological Survey; $\mu \mathrm{S} / \mathrm{cm}$, microsiemens per centimeter at 25 degrees Celsius; mg/L, milligrams per liter; $\mu \mathrm{g} / \mathrm{L}$, micrograms per liter; ${ }^{\circ} \mathrm{C}$, degrees Celsius; NTU, nephelometric turbidity unit; gal/min, gallons per minute; $\mathrm{CaCO}_{3}$, calcium carbonate; $\mathrm{HCO}_{3}$, bicarbonate; $\mathrm{SiO}_{2}$, silicate; $\mathrm{SO}_{4}$, sulfate; $\mathrm{N}$, nitrogen; $\mathrm{P}$, phosphate; <, less than; --, no value available; na, not applicable; E, quantified above the long-term method detection limit (LT-MDL) but below the laboratory reporting level (LRL) with higher uncertainty; bold type, detected pesticide concentration; District of Columbia surface-water standards A, B, C, and D refer to different surface-water uses: A = primary contact recreation; B = secondary contact recreation and aesthetic enjoyment; $\mathrm{C}=$ protection and propagation of fish, shellfish, and wildlife; $\mathrm{D}=$ protection of human health related to consumption of fish and shellfish (District of Columbia, 2006); d, diluted sample, method high end of range exceeded; ***, refer to District of Columbia (2006) for this value]

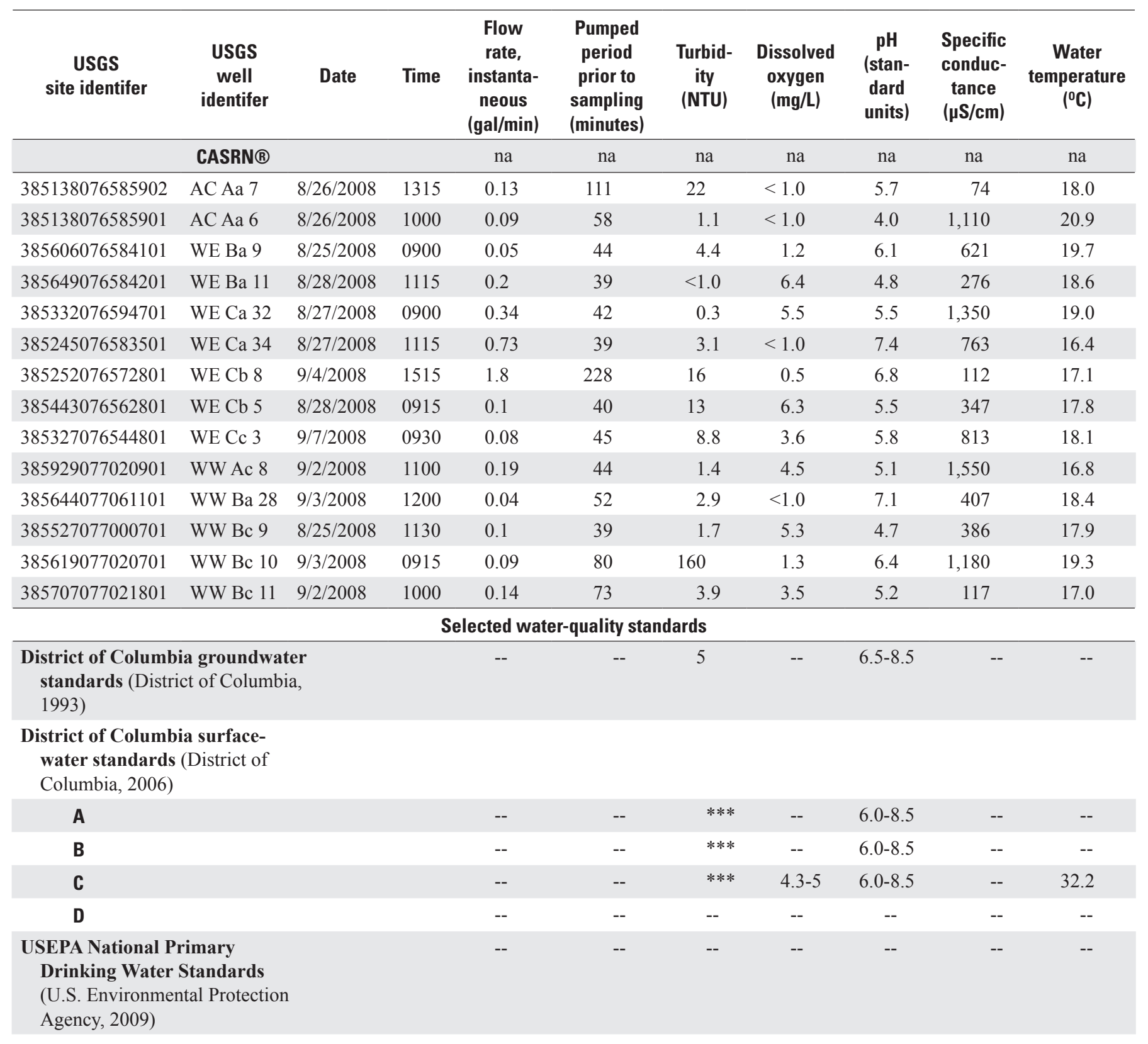


Table A1. Concentrations of major ions, nutrients, and pesticides in groundwater samples collected in the Anacostia River and Rock Creek watersheds in Washington, D.C., August to September 2008, and selected water-quality standards. - Continued

[CASRN®, Chemical Abstracts Service Registry Number; USGS, U.S. Geological Survey; $\mu \mathrm{S} / \mathrm{cm}$, microsiemens per centimeter at 25 degrees Celsius; mg/L, milligrams per liter; $\mu \mathrm{g} / \mathrm{L}$, micrograms per liter; ${ }^{\circ} \mathrm{C}$, degrees Celsius; NTU, nephelometric turbidity unit; gal $/ \mathrm{min}$, gallons per minute; $\mathrm{CaCO}_{3}$, calcium carbonate; $\mathrm{HCO}_{3}$, bicarbonate; $\mathrm{SiO}_{2}$, silicate; $\mathrm{SO}_{4}$, sulfate; $\mathrm{N}$, nitrogen; $\mathrm{P}$, phosphate; <, less than; --, no value available; na, not applicable; $\mathrm{E}$, quantified above the long-term method detection limit (LT-MDL) but below the laboratory reporting level (LRL) with higher uncertainty; bold type, detected pesticide concentration; District of Columbia surface-water standards A, B, C, and D refer to different surface-water uses: A = primary contact recreation; B = secondary contact recreation and aesthetic enjoyment; $\mathrm{C}=$ protection and propagation of fish, shellfish, and wildlife; $\mathrm{D}=$ protection of human health related to consumption of fish and shellfish (District of Columbia, 2006); d, diluted sample, method high end of range exceeded; ***, refer to District of Columbia (2006) for this value]

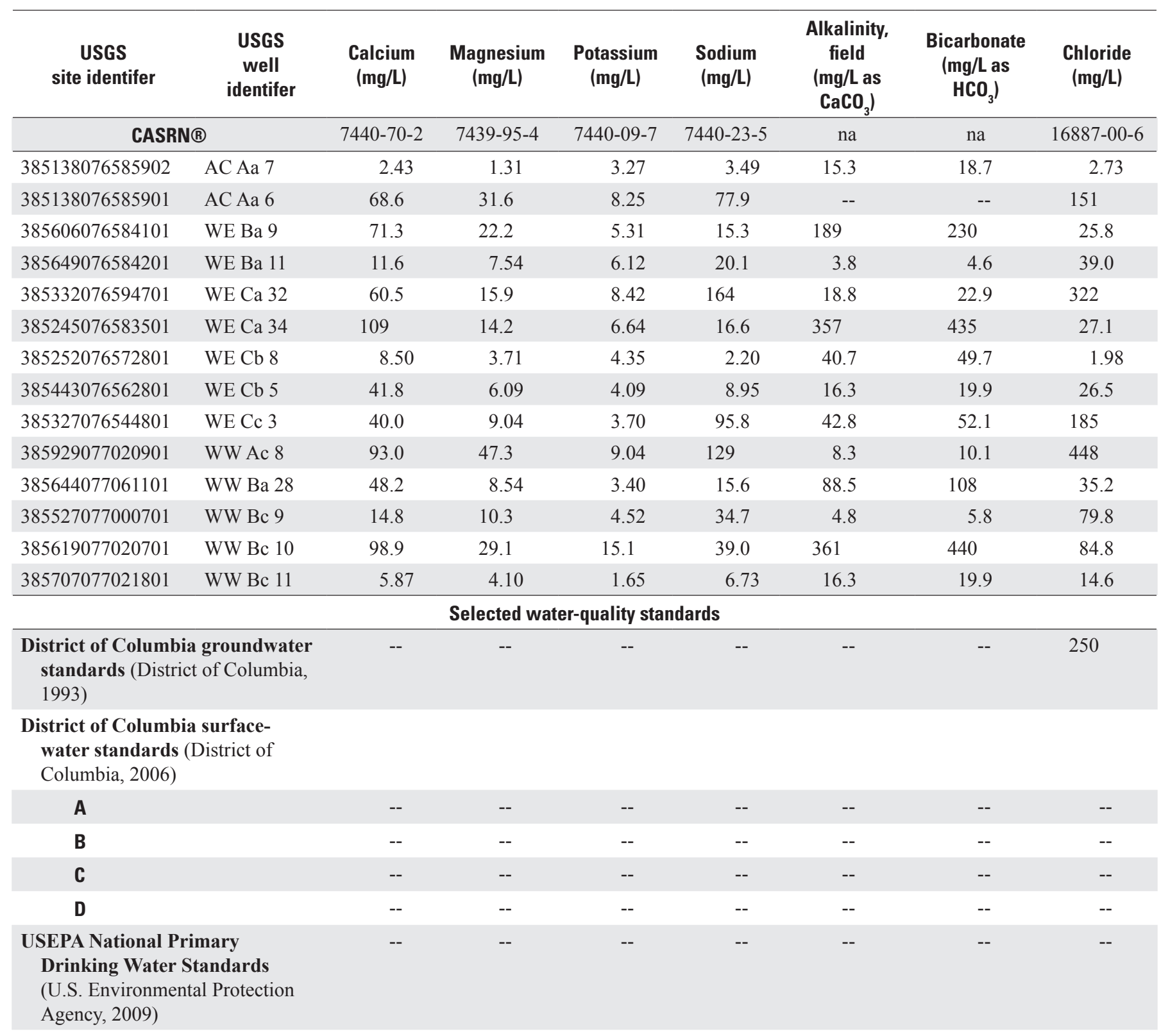


Table A1. Concentrations of major ions, nutrients, and pesticides in groundwater samples collected in the Anacostia River and Rock Creek watersheds in Washington, D.C., August to September 2008, and selected water-quality standards.-Continued

[CASRN ${ }^{\circledR}$, Chemical Abstracts Service Registry Number; USGS, U.S. Geological Survey; $\mu \mathrm{S} / \mathrm{cm}$, microsiemens per centimeter at 25 degrees Celsius; mg/L, milligrams per liter; $\mu \mathrm{g} / \mathrm{L}$, micrograms per liter; ${ }^{\circ} \mathrm{C}$, degrees Celsius; $\mathrm{NTU}$, nephelometric turbidity unit; gal $/ \mathrm{min}$, gallons per minute; $\mathrm{CaCO}_{3}$, calcium carbonate; $\mathrm{HCO}_{3}$, bicarbonate; $\mathrm{SiO}_{2}$, silicate; $\mathrm{SO}_{4}$, sulfate; $\mathrm{N}$, nitrogen; $\mathrm{P}$, phosphate; <, less than; --, no value available; na, not applicable; E, quantified above the long-term method detection limit (LT-MDL) but below the laboratory reporting level (LRL) with higher uncertainty; bold type, detected pesticide concentration; District of Columbia surface-water standards A, B, C, and D refer to different surface-water uses: A = primary contact recreation; B = secondary contact recreation and aesthetic enjoyment; $\mathrm{C}=$ protection and propagation of fish, shellfish, and wildlife; $\mathrm{D}=$ protection of human health related to consumption of fish and shellfish (District of Columbia, 2006); d, diluted sample, method high end of range exceeded; ***, refer to District of Columbia (2006) for this value]

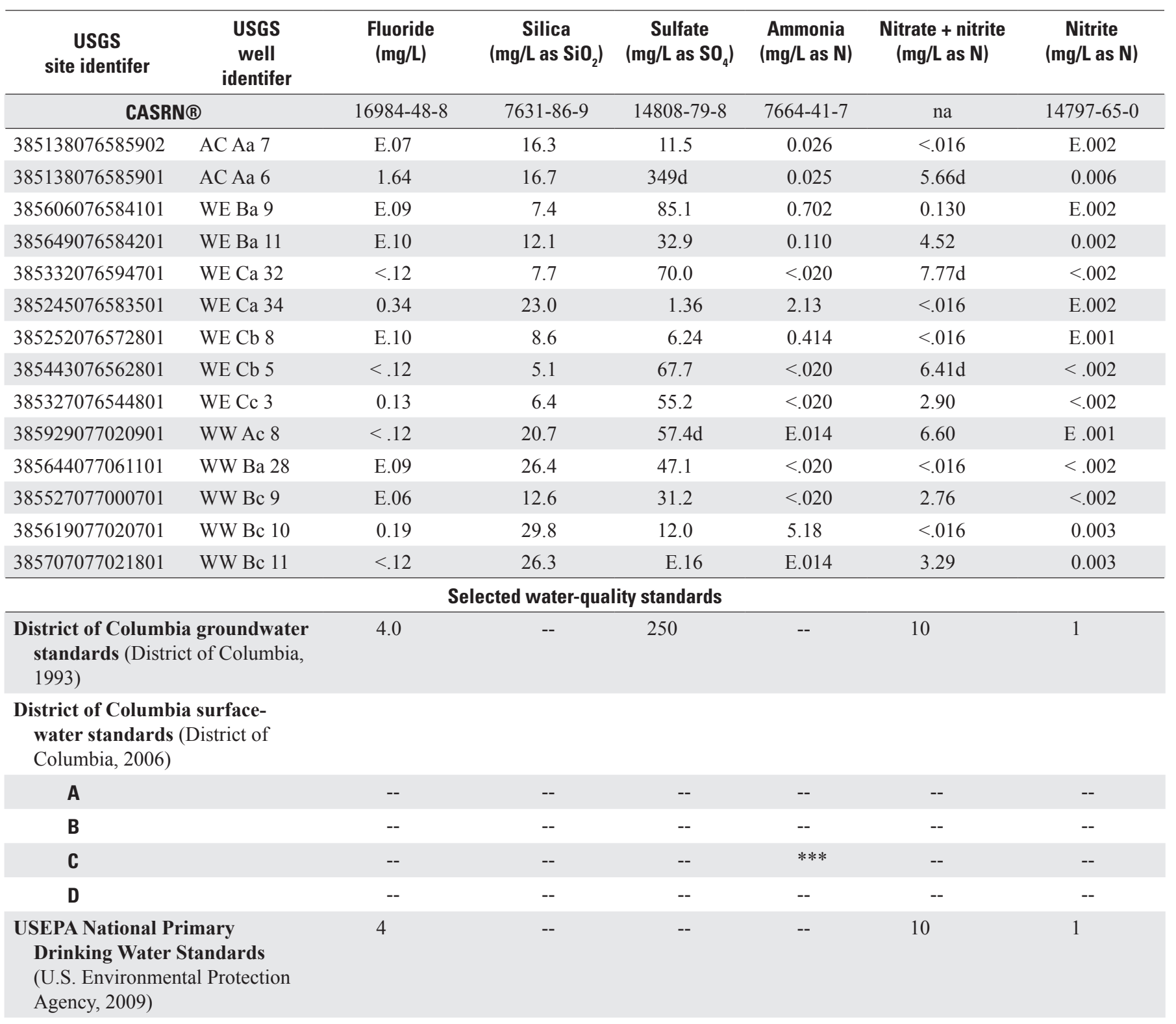


Table A1. Concentrations of major ions, nutrients, and pesticides in groundwater samples collected in the Anacostia River and Rock Creek watersheds in Washington, D.C., August to September 2008, and selected water-quality standards. - Continued

[CASRN®, Chemical Abstracts Service Registry Number; USGS, U.S. Geological Survey; $\mu \mathrm{S} / \mathrm{cm}$, microsiemens per centimeter at 25 degrees Celsius; mg/L, milligrams per liter; $\mu \mathrm{g} / \mathrm{L}$, micrograms per liter; ${ }^{\circ} \mathrm{C}$, degrees Celsius; NTU, nephelometric turbidity unit; gal $/ \mathrm{min}$, gallons per minute; $\mathrm{CaCO}_{3}$, calcium carbonate; $\mathrm{HCO}_{3}$, bicarbonate; $\mathrm{SiO}_{2}$, silicate; $\mathrm{SO}_{4}$, sulfate; $\mathrm{N}$, nitrogen; $\mathrm{P}$, phosphate; <, less than; --, no value available; na, not applicable; $\mathrm{E}$, quantified above the long-term method detection limit (LT-MDL) but below the laboratory reporting level (LRL) with higher uncertainty; bold type, detected pesticide concentration; District of Columbia surface-water standards A, B, C, and D refer to different surface-water uses: A = primary contact recreation; B = secondary contact recreation and aesthetic enjoyment; $\mathrm{C}=$ protection and propagation of fish, shellfish, and wildlife; $\mathrm{D}=$ protection of human health related to consumption of fish and shellfish (District of Columbia, 2006); d, diluted sample, method high end of range exceeded; ***, refer to District of Columbia (2006) for this value]

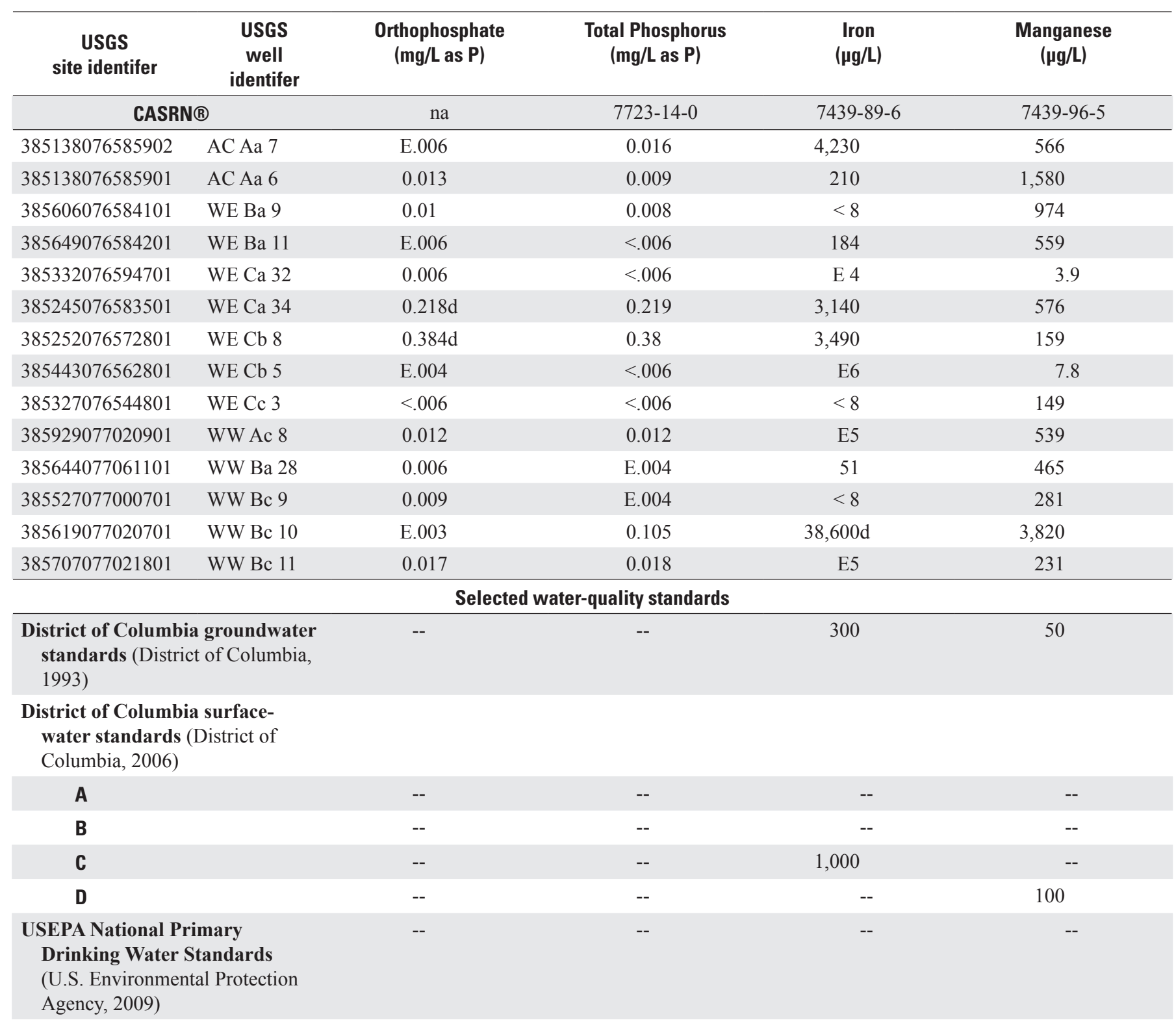


Table A1. Concentrations of major ions, nutrients, and pesticides in groundwater samples collected in the Anacostia River and Rock Creek watersheds in Washington, D.C., August to September 2008, and selected water-quality standards.—Continued

[CASRN ${ }^{\circledR}$, Chemical Abstracts Service Registry Number; USGS, U.S. Geological Survey; $\mu \mathrm{S} / \mathrm{cm}$, microsiemens per centimeter at 25 degrees Celsius; mg/L, milligrams per liter; $\mu \mathrm{g} / \mathrm{L}$, micrograms per liter; ${ }^{\circ} \mathrm{C}$, degrees Celsius; NTU, nephelometric turbidity unit; gal/min, gallons per minute; $\mathrm{CaCO}_{3}$, calcium carbonate; $\mathrm{HCO}_{3}$, bicarbonate; $\mathrm{SiO}_{2}$, silicate; $\mathrm{SO}_{4}$, sulfate; $\mathrm{N}$, nitrogen; $\mathrm{P}$, phosphate; <, less than; --, no value available; na, not applicable; E, quantified above the long-term method detection limit (LT-MDL) but below the laboratory reporting level (LRL) with higher uncertainty; bold type, detected pesticide concentration; District of Columbia surface-water standards A, B, C, and D refer to different surface-water uses: A = primary contact recreation; B = secondary contact recreation and aesthetic enjoyment; $\mathrm{C}=$ protection and propagation of fish, shellfish, and wildlife; $\mathrm{D}=$ protection of human health related to consumption of fish and shellfish (District of Columbia, 2006); d, diluted sample, method high end of range exceeded; ***, refer to District of Columbia (2006) for this value]

\begin{tabular}{|c|c|c|c|c|c|c|c|c|}
\hline $\begin{array}{c}\text { USGS } \\
\text { site identifer }\end{array}$ & $\begin{array}{c}\text { USGS } \\
\text { well } \\
\text { identifer }\end{array}$ & \multicolumn{7}{|c|}{ Pesticides and pesticide degradates } \\
\hline 385138076585902 & AC Aa 7 & $<.04$ & $<.040$ & $<.02$ & $<.02$ & $<.02$ & $<.006$ & $<.010$ \\
\hline 385138076585901 & AC Aa 6 & $<.04$ & $<.040$ & $<.02$ & $<.02$ & $<.02$ & $<.006$ & $<.010$ \\
\hline 385606076584101 & WE Ba 9 & $<.04$ & $<.040$ & $<.02$ & $<.02$ & $<.02$ & $<.006$ & $<.010$ \\
\hline 385649076584201 & WE Ba 11 & $<.04$ & $<.040$ & $<.02$ & $<.02$ & $<.02$ & $<.006$ & $<.010$ \\
\hline 385332076594701 & WE Ca 32 & $<.04$ & $<.040$ & $<.02$ & $<.02$ & $<.02$ & $<.006$ & $<.010$ \\
\hline 385327076544801 & WE Cc 3 & $<.04$ & $<.040$ & $<.02$ & $<.02$ & $<.02$ & $<.006$ & $<.010$ \\
\hline 385929077020901 & WW Ac 8 & $<.04$ & $<.040$ & $<.02$ & $<.02$ & $<.02$ & $<.006$ & $<.010$ \\
\hline 385644077061101 & WW Ba 28 & $<.04$ & $<.040$ & $<.02$ & $<.02$ & $<.02$ & $<.006$ & $<.010$ \\
\hline 385527077000701 & WW Bc 9 & $<.04$ & $<.040$ & $<.02$ & $<.02$ & $<.02$ & $<.006$ & $<.010$ \\
\hline 385619077020701 & WW Bc 10 & $<.04$ & $<.040$ & $<.02$ & $<.02$ & $<.02$ & $<.006$ & $<.026$ \\
\hline 385707077021801 & WW Bc 11 & $<.04$ & $<.040$ & $<.02$ & $<.02$ & $<.02$ & $<.006$ & $<.010$ \\
\hline \multicolumn{9}{|c|}{ Selected water-quality standards } \\
\hline \multicolumn{2}{|c|}{$\begin{array}{l}\text { District of Columbia groundwater } \\
\text { standards (District of Columbia, } \\
\text { 1993) }\end{array}$} & -- & -- & -- & 100 & -- & -- & \\
\hline C & & -- & -- & & -- & -- & -- & \\
\hline D & & -- & -- & & -- & -- & -- & \\
\hline \multicolumn{2}{|c|}{$\begin{array}{l}\text { USEPA National Primary } \\
\text { Drinking Water Standards } \\
\text { (U.S. Environmental Protection } \\
\text { Agency, 2009) }\end{array}$} & -- & -- & & 70 & -- & -- & \\
\hline
\end{tabular}


Table A1. Concentrations of major ions, nutrients, and pesticides in groundwater samples collected in the Anacostia River and Rock Creek watersheds in Washington, D.C., August to September 2008, and selected water-quality standards. - Continued

[CASRN®, Chemical Abstracts Service Registry Number; USGS, U.S. Geological Survey; $\mu \mathrm{S} / \mathrm{cm}$, microsiemens per centimeter at 25 degrees Celsius; mg/L, milligrams per liter; $\mu \mathrm{g} / \mathrm{L}$, micrograms per liter; ${ }^{\circ} \mathrm{C}$, degrees Celsius; NTU, nephelometric turbidity unit; gal $/ \mathrm{min}$, gallons per minute; $\mathrm{CaCO}_{3}$, calcium carbonate; $\mathrm{HCO}_{3}$, bicarbonate; $\mathrm{SiO}_{2}$, silicate; $\mathrm{SO}_{4}$, sulfate; $\mathrm{N}$, nitrogen; $\mathrm{P}$, phosphate; <, less than; --, no value available; na, not applicable; E, quantified above the long-term method detection limit (LT-MDL) but below the laboratory reporting level (LRL) with higher uncertainty; bold type, detected pesticide concentration; District of Columbia surface-water standards A, B, C, and D refer to different surface-water uses: A = primary contact recreation; B = secondary contact recreation and aesthetic enjoyment; $\mathrm{C}=$ protection and propagation of fish, shellfish, and wildlife; $\mathrm{D}=$ protection of human health related to consumption of fish and shellfish (District of Columbia, 2006); d, diluted sample, method high end of range exceeded; ***, refer to District of Columbia (2006) for this value]

\begin{tabular}{|c|c|c|c|c|c|c|c|}
\hline \multirow[b]{2}{*}{$\begin{array}{c}\text { USGS } \\
\text { site identifer }\end{array}$} & \multirow[b]{2}{*}{$\begin{array}{c}\text { USGS } \\
\text { well } \\
\text { identifer }\end{array}$} & \multicolumn{6}{|c|}{ Pesticides and pesticide degradates } \\
\hline & & $\begin{array}{c}\text { 2-hydroxy-4- } \\
\text { isopropyl-amino- } \\
\text { 6-ethylamino-s- } \\
\text { triazine (CIAT) } \\
(\mu \mathrm{g} / \mathrm{L})\end{array}$ & $\begin{array}{c}\text { 2-chloro-4- } \\
\text { ethylamino-6- } \\
\text { amino-s-triazine } \\
\text { (CEAT) } \\
(\mu \mathrm{g} / \mathrm{L})\end{array}$ & $\begin{array}{c}\text { 2-Ethyl-6- } \\
\text { methylaniline } \\
(\mu \mathrm{g} / \mathrm{L})\end{array}$ & $\begin{array}{c}\text { 2-chloro-4-iso- } \\
\text { propylamino-6- } \\
\text { amino-s-triazine } \\
\text { (OIET) } \\
(\mu \mathrm{g} / \mathrm{L})\end{array}$ & $\begin{array}{l}\text { 3,4-Dichlo- } \\
\text { roaniline } \\
\text { ( } \mu \mathrm{g} / \mathrm{L})\end{array}$ & $\begin{array}{c}\text { 3,5-Dichlo- } \\
\text { roaniline } \\
(\mu \mathrm{g} / \mathrm{L})\end{array}$ \\
\hline \multicolumn{2}{|c|}{ CASRN® } & $1007-28-9$ & $2163-68-0$ & $24549-06-2$ & $2163-68-0$ & $95-76-1$ & $626-43-7$ \\
\hline 385138076585901 & AC Aa 6 & $<.014$ & $<.08$ & $<.010$ & $<.040$ & $<.006$ & $<.008$ \\
\hline 385606076584101 & WE Ba 9 & E.006 & $<.08$ & $<.010$ & $<.040$ & $<.006$ & $<.008$ \\
\hline 385649076584201 & WE Ba 11 & $<.014$ & $<.08$ & $<.010$ & $<.040$ & $<.006$ & $<.008$ \\
\hline 385332076594701 & WE Ca 32 & E.022 & $<.08$ & $<.010$ & $<.040$ & E.006 & $<.008$ \\
\hline 385327076544801 & WE Cc 3 & E.014 & $<.08$ & $<.010$ & E.013 & $<.006$ & $<.008$ \\
\hline 385929077020901 & WW Ac 8 & E.020 & $<.08$ & $<.010$ & $<.040$ & $<.006$ & $<.008$ \\
\hline 385644077061101 & WW Ba 28 & $<.014$ & $<.08$ & $<.010$ & $<.040$ & $<.006$ & $<.008$ \\
\hline 385527077000701 & WW Bc 9 & E.013 & $<.08$ & $<.010$ & $<.040$ & $<.006$ & $<.008$ \\
\hline 385619077020701 & WW Bc 10 & $<.014$ & $<.08$ & $<.010$ & $<.040$ & $<.070$ & $<.008$ \\
\hline 385707077021801 & WW Bc 11 & $<.014$ & $<.08$ & $<.010$ & $<.040$ & $<.006$ & $<.008$ \\
\hline \multicolumn{8}{|c|}{ Selected water-quality standards } \\
\hline $\begin{array}{l}\text { District of Columb } \\
\text { standards (Distr } \\
\text { 1993) }\end{array}$ & $\begin{array}{l}\text { groundwater } \\
\text { of Columbia, }\end{array}$ & -- & -- & -- & -- & -- & -- \\
\hline D & & -- & -- & -- & -- & -- & -- \\
\hline \multicolumn{2}{|c|}{$\begin{array}{l}\text { USEPA National Primary } \\
\text { Drinking Water Standards } \\
\text { (U.S. Environmental Protection } \\
\text { Agency, 2009) }\end{array}$} & -- & -- & -- & -- & -- & -- \\
\hline
\end{tabular}


Table A1. Concentrations of major ions, nutrients, and pesticides in groundwater samples collected in the Anacostia River and Rock Creek watersheds in Washington, D.C., August to September 2008, and selected water-quality standards.-Continued

[CASRN ${ }^{\circledR}$, Chemical Abstracts Service Registry Number; USGS, U.S. Geological Survey; $\mu \mathrm{S} / \mathrm{cm}$, microsiemens per centimeter at 25 degrees Celsius; mg/L, milligrams per liter; $\mu \mathrm{g} / \mathrm{L}$, micrograms per liter; ${ }^{\circ} \mathrm{C}$, degrees Celsius; $\mathrm{NTU}$, nephelometric turbidity unit; gal $/ \mathrm{min}$, gallons per minute; $\mathrm{CaCO}_{3}$, calcium carbonate; $\mathrm{HCO}_{3}$, bicarbonate; $\mathrm{SiO}_{2}$, silicate; $\mathrm{SO}_{4}$, sulfate; $\mathrm{N}$, nitrogen; $\mathrm{P}$, phosphate; <, less than; --, no value available; na, not applicable; E, quantified above the long-term method detection limit (LT-MDL) but below the laboratory reporting level (LRL) with higher uncertainty; bold type, detected pesticide concentration; District of Columbia surface-water standards A, B, C, and D refer to different surface-water uses: A = primary contact recreation; B = secondary contact recreation and aesthetic enjoyment; $\mathrm{C}=$ protection and propagation of fish, shellfish, and wildlife; $\mathrm{D}=$ protection of human health related to consumption of fish and shellfish (District of Columbia, 2006); d, diluted sample, method high end of range exceeded; ***, refer to District of Columbia (2006) for this value]

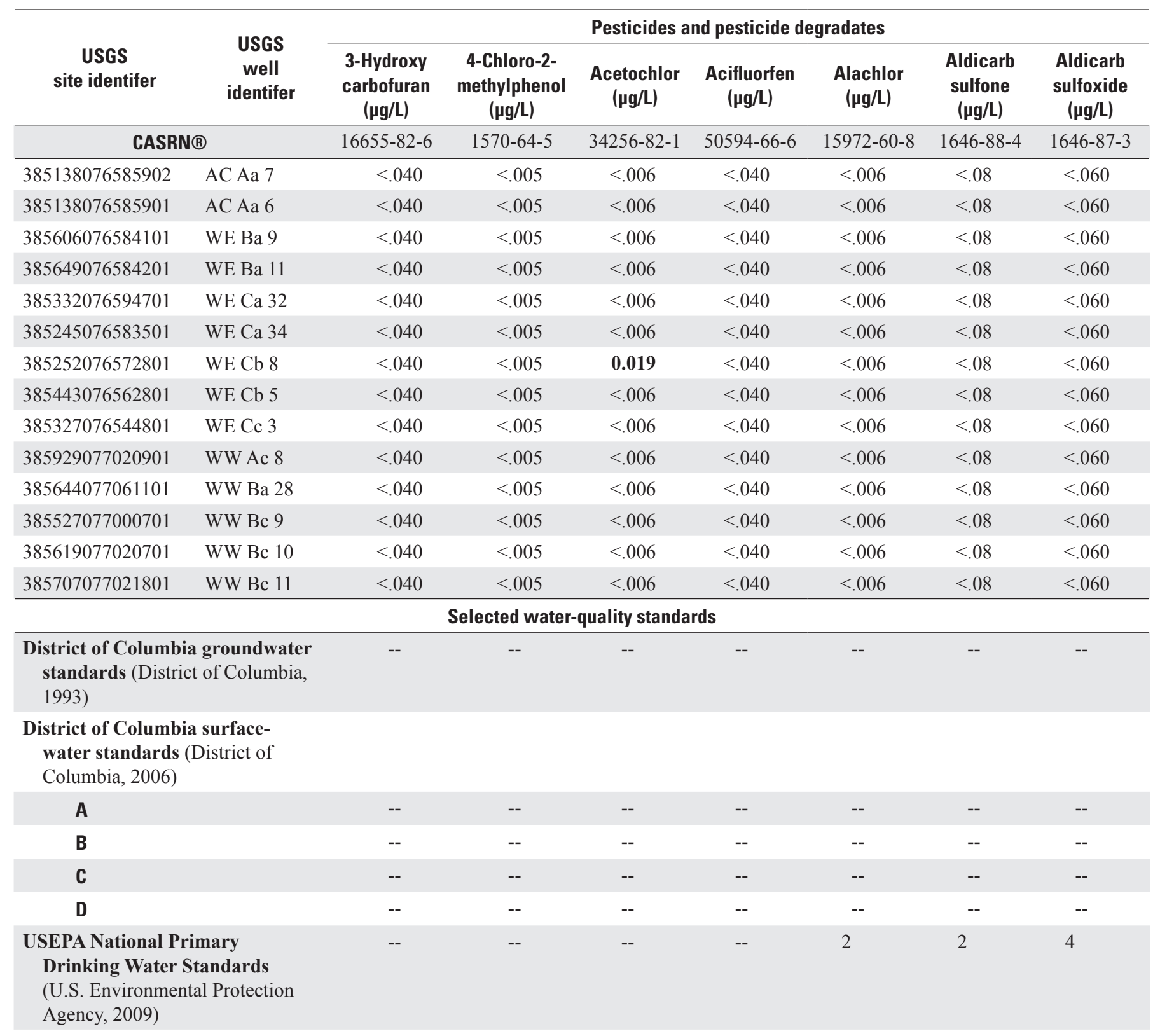


Table A1. Concentrations of major ions, nutrients, and pesticides in groundwater samples collected in the Anacostia River and Rock Creek watersheds in Washington, D.C., August to September 2008, and selected water-quality standards. - Continued

[CASRN®, Chemical Abstracts Service Registry Number; USGS, U.S. Geological Survey; $\mu \mathrm{S} / \mathrm{cm}$, microsiemens per centimeter at 25 degrees Celsius; mg/L, milligrams per liter; $\mu \mathrm{g} / \mathrm{L}$, micrograms per liter; ${ }^{\circ} \mathrm{C}$, degrees Celsius; NTU, nephelometric turbidity unit; gal $/ \mathrm{min}$, gallons per minute; $\mathrm{CaCO}_{3}$, calcium carbonate; $\mathrm{HCO}_{3}$, bicarbonate; $\mathrm{SiO}_{2}$, silicate; $\mathrm{SO}_{4}$, sulfate; N, nitrogen; $\mathrm{P}$, phosphate; <, less than; --, no value available; na, not applicable; E, quantified above the long-term method detection limit (LT-MDL) but below the laboratory reporting level (LRL) with higher uncertainty; bold type, detected pesticide concentration; District of Columbia surface-water standards A, B, C, and D refer to different surface-water uses: A = primary contact recreation; B = secondary contact recreation and aesthetic enjoyment; $\mathrm{C}=$ protection and propagation of fish, shellfish, and wildlife; $\mathrm{D}=$ protection of human health related to consumption of fish and shellfish (District of Columbia, 2006); d, diluted sample, method high end of range exceeded; ***, refer to District of Columbia (2006) for this value]

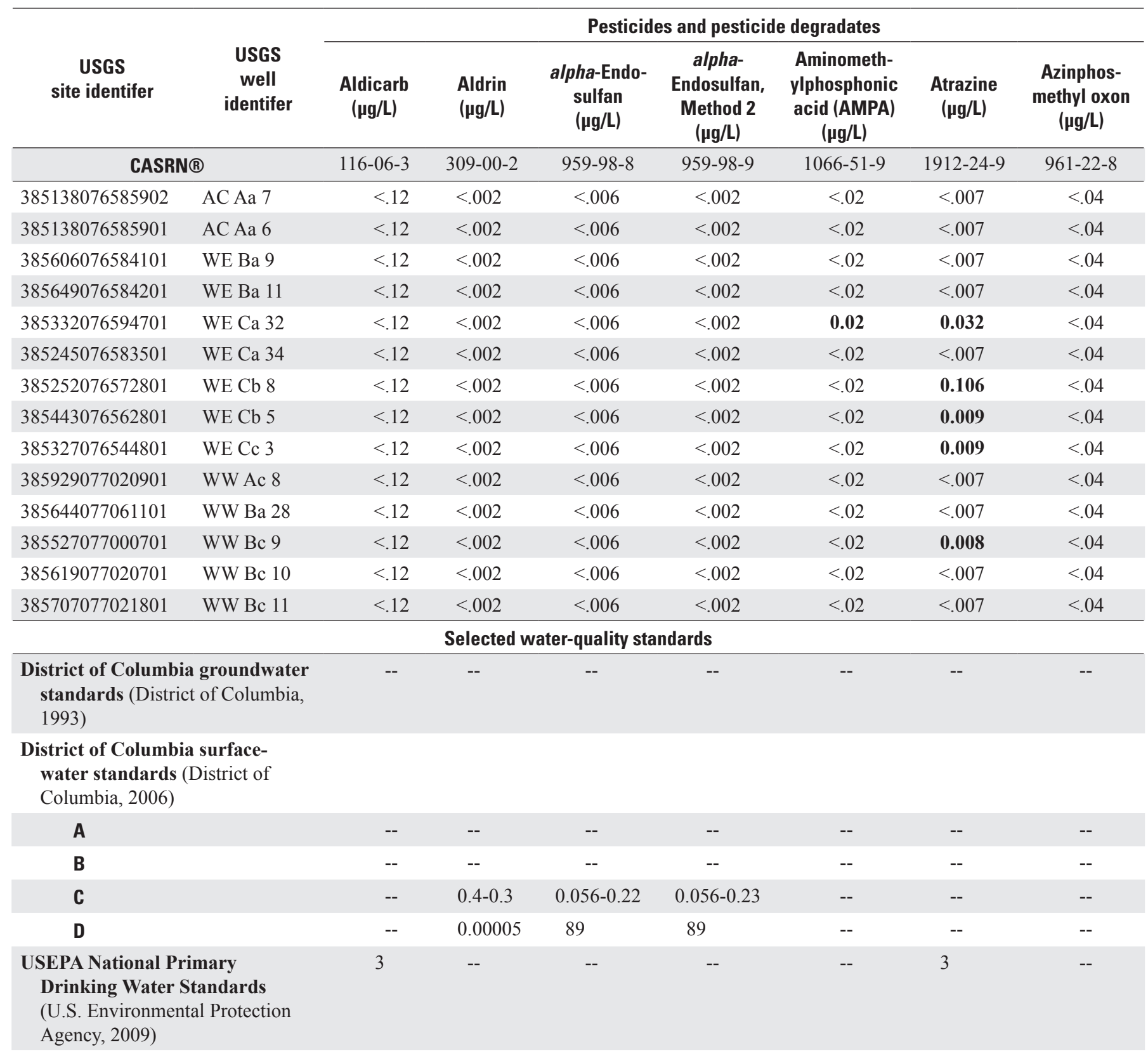


Table A1. Concentrations of major ions, nutrients, and pesticides in groundwater samples collected in the Anacostia River and Rock Creek watersheds in Washington, D.C., August to September 2008, and selected water-quality standards.—Continued

[CASRN ${ }^{\circledR}$, Chemical Abstracts Service Registry Number; USGS, U.S. Geological Survey; $\mu \mathrm{S} / \mathrm{cm}$, microsiemens per centimeter at 25 degrees Celsius; mg/L, milligrams per liter; $\mu \mathrm{g} / \mathrm{L}$, micrograms per liter; ${ }^{\circ} \mathrm{C}$, degrees Celsius; NTU, nephelometric turbidity unit; gal/min, gallons per minute; $\mathrm{CaCO}_{3}$, calcium carbonate; $\mathrm{HCO}_{3}$, bicarbonate; $\mathrm{SiO}_{2}$, silicate; $\mathrm{SO}_{4}$, sulfate; $\mathrm{N}$, nitrogen; $\mathrm{P}$, phosphate; <, less than; --, no value available; na, not applicable; E, quantified above the long-term method detection limit (LT-MDL) but below the laboratory reporting level (LRL) with higher uncertainty; bold type, detected pesticide concentration; District of Columbia surface-water standards A, B, C, and D refer to different surface-water uses: A = primary contact recreation; B = secondary contact recreation and aesthetic enjoyment; $\mathrm{C}=$ protection and propagation of fish, shellfish, and wildlife; $\mathrm{D}=$ protection of human health related to consumption of fish and shellfish (District of Columbia, 2006); d, diluted sample, method high end of range exceeded; ***, refer to District of Columbia (2006) for this value]

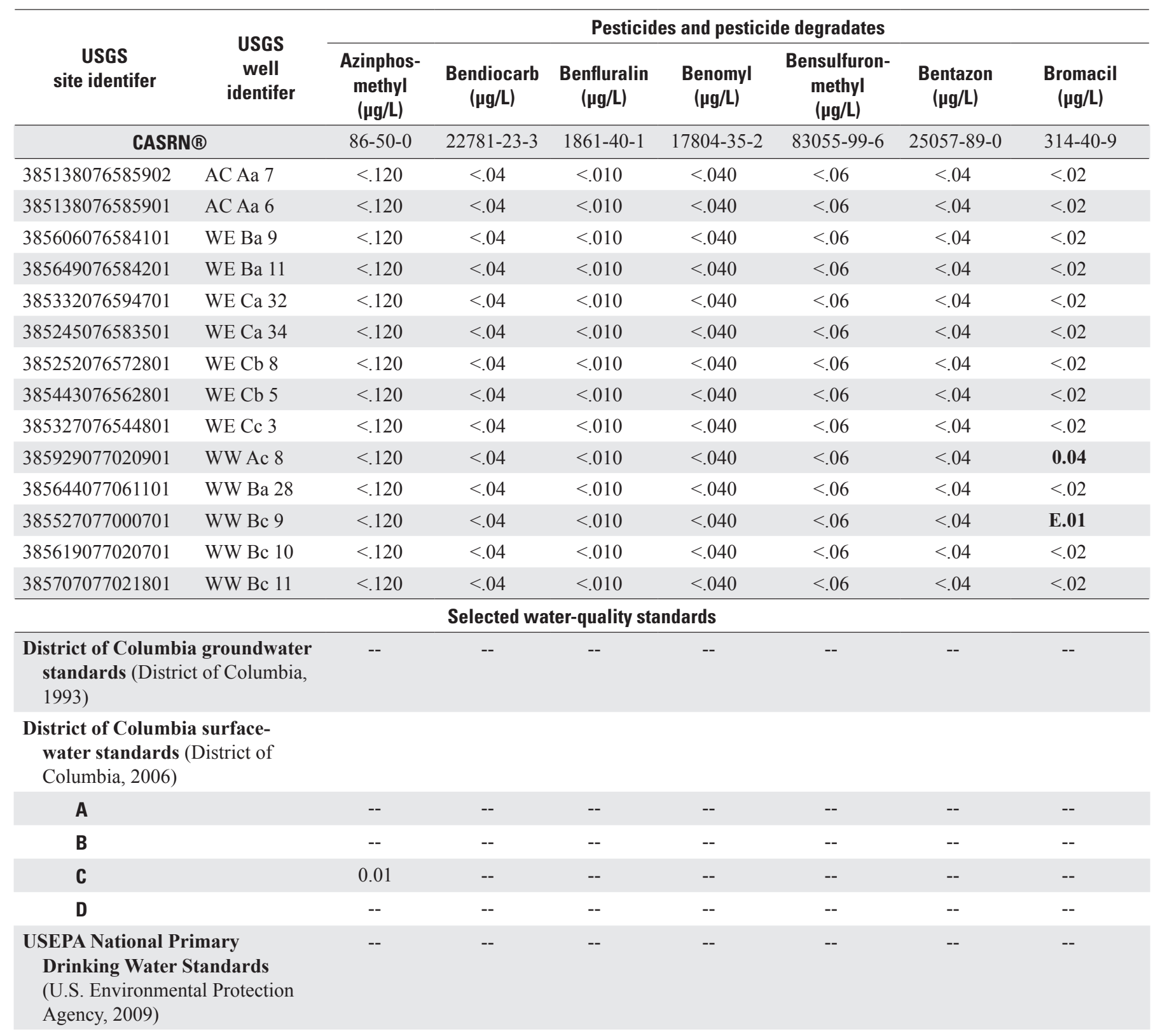


Table A1. Concentrations of major ions, nutrients, and pesticides in groundwater samples collected in the Anacostia River and Rock Creek watersheds in Washington, D.C., August to September 2008, and selected water-quality standards. - Continued

[CASRN®, Chemical Abstracts Service Registry Number; USGS, U.S. Geological Survey; $\mu \mathrm{S} / \mathrm{cm}$, microsiemens per centimeter at 25 degrees Celsius; mg/L, milligrams per liter; $\mu \mathrm{g} / \mathrm{L}$, micrograms per liter; ${ }^{\circ} \mathrm{C}$, degrees Celsius; NTU, nephelometric turbidity unit; gal $/ \mathrm{min}$, gallons per minute; $\mathrm{CaCO}_{3}$, calcium carbonate; $\mathrm{HCO}_{3}$, bicarbonate; $\mathrm{SiO}_{2}$, silicate; $\mathrm{SO}_{4}$, sulfate; $\mathrm{N}$, nitrogen; $\mathrm{P}$, phosphate; <, less than; --, no value available; na, not applicable; $\mathrm{E}$, quantified above the long-term method detection limit (LT-MDL) but below the laboratory reporting level (LRL) with higher uncertainty; bold type, detected pesticide concentration; District of Columbia surface-water standards A, B, C, and D refer to different surface-water uses: A = primary contact recreation; B = secondary contact recreation and aesthetic enjoyment; $\mathrm{C}=$ protection and propagation of fish, shellfish, and wildlife; $\mathrm{D}=$ protection of human health related to consumption of fish and shellfish (District of Columbia, 2006); d, diluted sample, method high end of range exceeded; ***, refer to District of Columbia (2006) for this value]

\begin{tabular}{|c|c|c|c|c|c|c|c|c|c|}
\hline \multirow[b]{2}{*}{$\begin{array}{c}\text { USGS } \\
\text { site identifer }\end{array}$} & \multirow[b]{2}{*}{$\begin{array}{c}\text { USGS } \\
\text { well } \\
\text { identifer }\end{array}$} & \multicolumn{8}{|c|}{ Pesticides and pesticide degradates } \\
\hline & & $\begin{array}{c}\text { Bro- } \\
\text { moxynil } \\
(\mu g / L)\end{array}$ & $\begin{array}{c}\text { Caffeine } \\
\text { ( } \mu \mathrm{g} / \mathrm{L})\end{array}$ & $\begin{array}{c}\text { Carbaryl } \\
(\mu \mathrm{g} / \mathrm{L})\end{array}$ & $\begin{array}{c}\text { Carbaryl } \\
\text { ( } \mu \mathrm{g} / \mathrm{L})\end{array}$ & $\begin{array}{c}\text { Carbofuran } \\
(\mu \mathrm{g} / \mathrm{L})\end{array}$ & $\begin{array}{l}\text { Carbofu- } \\
\text { ran } \\
(\mu \mathrm{g} / \mathrm{L})\end{array}$ & $\begin{array}{l}\text { Chloram- } \\
\text { ben methyl } \\
\text { ester } \\
(\mu \mathrm{g} / \mathrm{L})\end{array}$ & $\begin{array}{c}\text { Chlordane } \\
\text { (technical) } \\
(\mu \mathrm{g} / \mathrm{L})\end{array}$ \\
\hline \multicolumn{2}{|c|}{ CASRN® } & $1689-84-5$ & $58-08-02$ & $63-25-2$ & $63-25-3$ & $1563-66-2$ & $1563-66-3$ & $7286-84-2$ & $57-74-9$ \\
\hline 385138076585902 & AC Aa 7 & $<.12$ & $<.060$ & $<.04$ & $<.060$ & $<.020$ & $<.020$ & $<.10$ & $<.1$ \\
\hline 385606076584101 & WE Ba 9 & $<.12$ & $<.060$ & $<.04$ & $<.060$ & $<.020$ & $<.020$ & $<.10$ & $<.1$ \\
\hline 385649076584201 & WE Ba 11 & $<.12$ & $<.060$ & $<.04$ & $<.060$ & $<.020$ & $<.020$ & $<.10$ & $<.1$ \\
\hline 385332076594701 & WE Ca 32 & $<.12$ & $<.060$ & $<.04$ & $<.060$ & $<.020$ & $<.020$ & $<.10$ & $<.1$ \\
\hline 385245076583501 & WE Ca 34 & $<.12$ & $<.060$ & $<.04$ & $<.060$ & $<.020$ & $<.020$ & $<.10$ & $<.1$ \\
\hline 385929077020901 & WW Ac 8 & $<.12$ & $<.060$ & $<.04$ & $<.060$ & $<.020$ & $<.020$ & $<.10$ & $<.1$ \\
\hline 385644077061101 & WW Ba 28 & $<.12$ & $<.060$ & $<.04$ & $<.060$ & $<.020$ & $<.020$ & $<.10$ & $<.1$ \\
\hline 385527077000701 & WW Bc 9 & $<.12$ & $<.060$ & $<.04$ & $<.060$ & $<.020$ & $<.020$ & $<.10$ & $<.1$ \\
\hline 385619077020701 & WW Bc 10 & $<.12$ & $<.060$ & $<.04$ & $<.060$ & $<.020$ & $<.020$ & $<.10$ & $<.1$ \\
\hline 385707077021801 & WW Bc 11 & $<.12$ & $<.060$ & $<.04$ & $<.060$ & $<.020$ & $<.020$ & $<.10$ & $<.1$ \\
\hline \multicolumn{10}{|c|}{ Selected water-quality standards } \\
\hline $\begin{array}{l}\text { District of Columb } \\
\text { standards (Distri } \\
\text { 1993) }\end{array}$ & $\begin{array}{l}\text { groundwater } \\
\text { of Columbia, }\end{array}$ & -- & -- & -- & -- & -- & -- & -- & -- \\
\hline D & & -- & -- & -- & -- & -- & -- & -- & 0.00081 \\
\hline \multicolumn{2}{|c|}{$\begin{array}{l}\text { USEPA National Primary } \\
\text { Drinking Water Standards } \\
\text { (U.S. Environmental Protection } \\
\text { Agency, 2009) }\end{array}$} & -- & -- & -- & -- & 40 & 40 & -- & 2 \\
\hline
\end{tabular}


Table A1. Concentrations of major ions, nutrients, and pesticides in groundwater samples collected in the Anacostia River and Rock Creek watersheds in Washington, D.C., August to September 2008, and selected water-quality standards.-Continued

[CASRN ${ }^{\circledR}$, Chemical Abstracts Service Registry Number; USGS, U.S. Geological Survey; $\mu \mathrm{S} / \mathrm{cm}$, microsiemens per centimeter at 25 degrees Celsius; mg/L, milligrams per liter; $\mu \mathrm{g} / \mathrm{L}$, micrograms per liter; ${ }^{\circ} \mathrm{C}$, degrees Celsius; $\mathrm{NTU}$, nephelometric turbidity unit; gal $/ \mathrm{min}$, gallons per minute; $\mathrm{CaCO}_{3}$, calcium carbonate; $\mathrm{HCO}_{3}$, bicarbonate; $\mathrm{SiO}_{2}$, silicate; $\mathrm{SO}_{4}$, sulfate; $\mathrm{N}$, nitrogen; $\mathrm{P}$, phosphate; <, less than; --, no value available; na, not applicable; E, quantified above the long-term method detection limit (LT-MDL) but below the laboratory reporting level (LRL) with higher uncertainty; bold type, detected pesticide concentration; District of Columbia surface-water standards A, B, C, and D refer to different surface-water uses: A = primary contact recreation; B = secondary contact recreation and aesthetic enjoyment; $\mathrm{C}=$ protection and propagation of fish, shellfish, and wildlife; $\mathrm{D}=$ protection of human health related to consumption of fish and shellfish (District of Columbia, 2006); d, diluted sample, method high end of range exceeded; ***, refer to District of Columbia (2006) for this value]

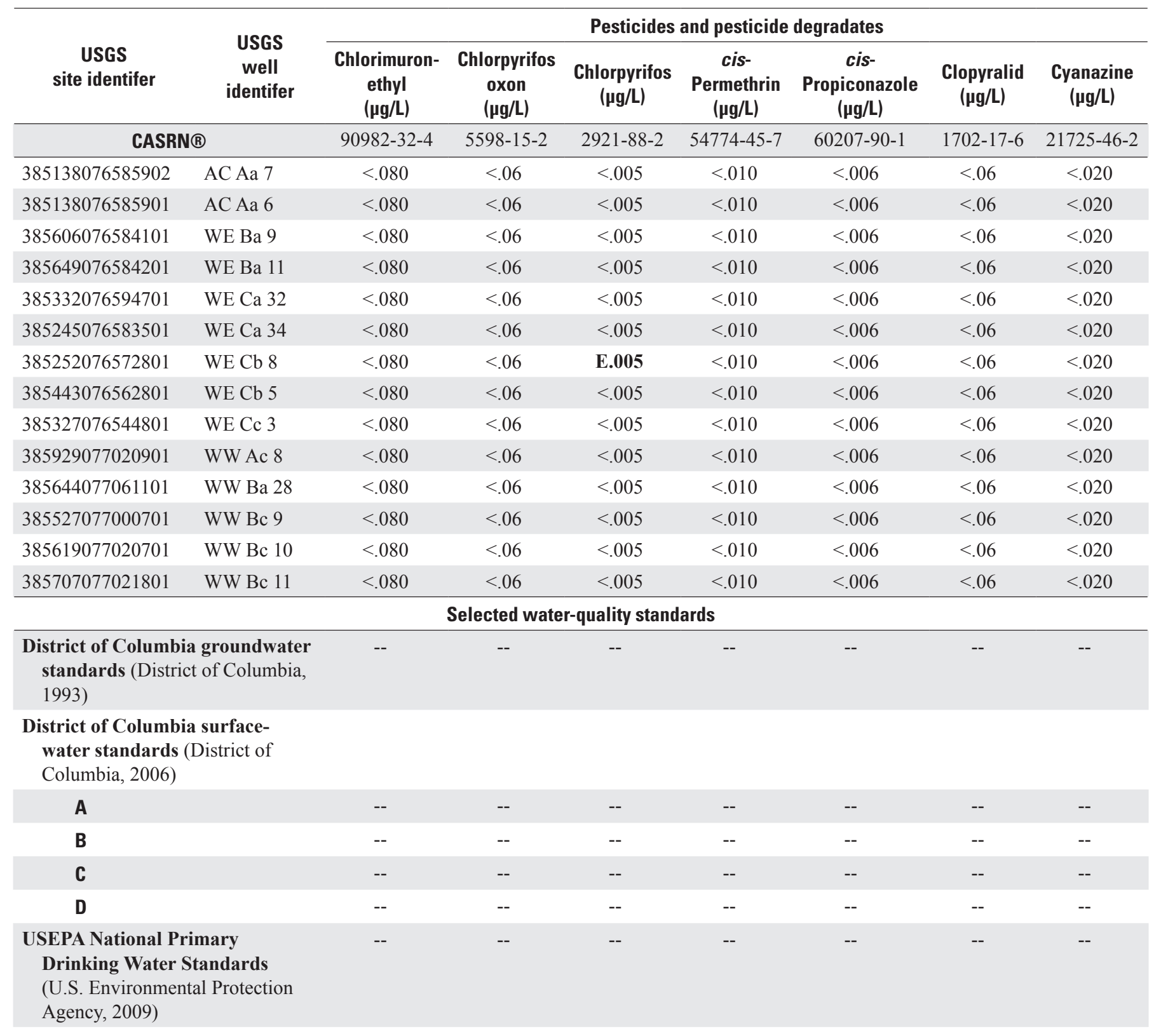


Table A1. Concentrations of major ions, nutrients, and pesticides in groundwater samples collected in the Anacostia River and Rock Creek watersheds in Washington, D.C., August to September 2008, and selected water-quality standards. - Continued

[CASRN®, Chemical Abstracts Service Registry Number; USGS, U.S. Geological Survey; $\mu \mathrm{S} / \mathrm{cm}$, microsiemens per centimeter at 25 degrees Celsius; mg/L, milligrams per liter; $\mu \mathrm{g} / \mathrm{L}$, micrograms per liter; ${ }^{\circ} \mathrm{C}$, degrees Celsius; NTU, nephelometric turbidity unit; gal $/ \mathrm{min}$, gallons per minute; $\mathrm{CaCO}_{3}$, calcium carbonate; $\mathrm{HCO}_{3}$, bicarbonate; $\mathrm{SiO}_{2}$, silicate; $\mathrm{SO}_{4}$, sulfate; $\mathrm{N}$, nitrogen; $\mathrm{P}$, phosphate; <, less than; --, no value available; na, not applicable; $\mathrm{E}$, quantified above the long-term method detection limit (LT-MDL) but below the laboratory reporting level (LRL) with higher uncertainty; bold type, detected pesticide concentration; District of Columbia surface-water standards A, B, C, and D refer to different surface-water uses: A = primary contact recreation; B = secondary contact recreation and aesthetic enjoyment; $\mathrm{C}=$ protection and propagation of fish, shellfish, and wildlife; $\mathrm{D}=$ protection of human health related to consumption of fish and shellfish (District of Columbia, 2006); d, diluted sample, method high end of range exceeded; ***, refer to District of Columbia (2006) for this value]

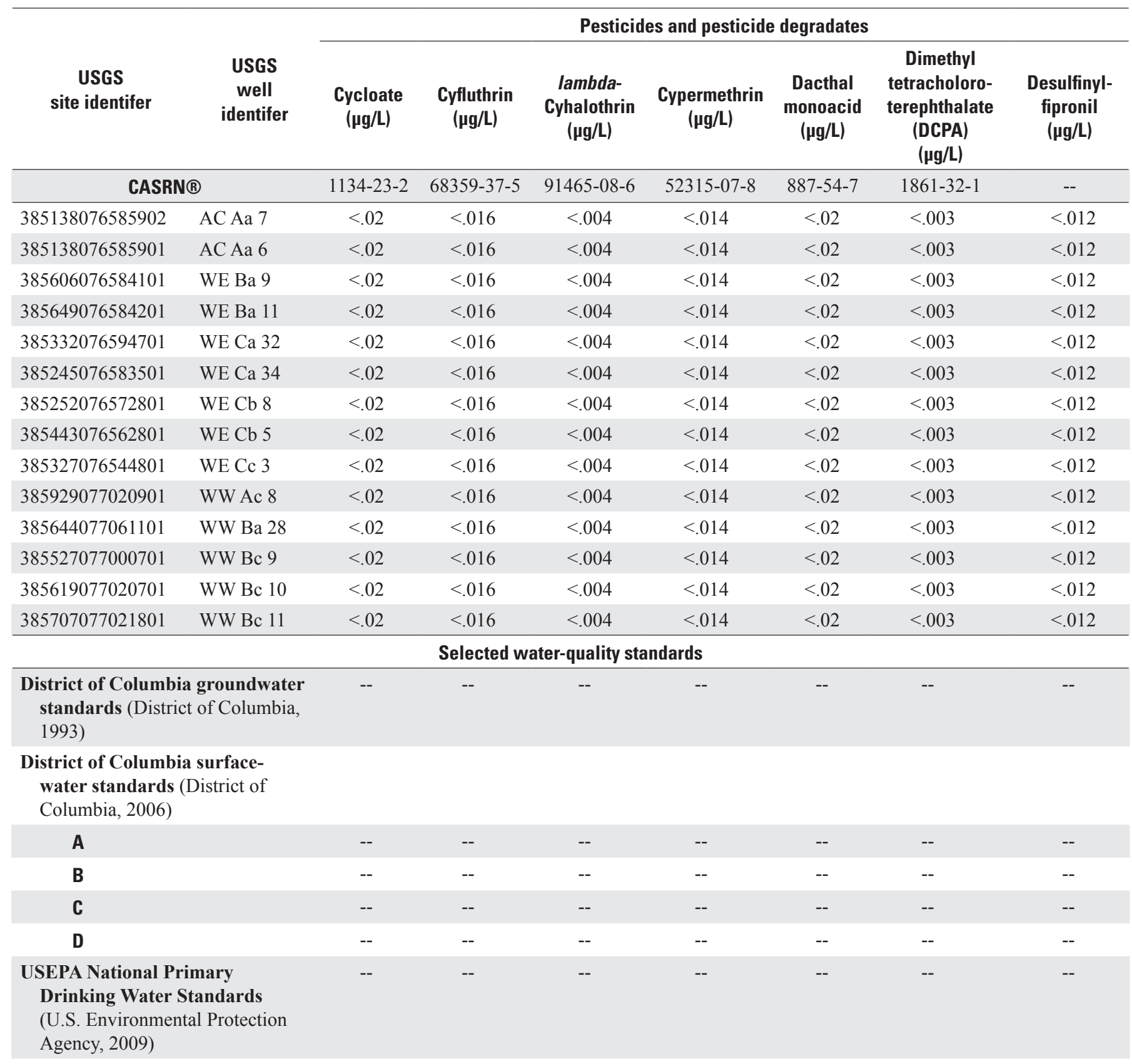


Table A1. Concentrations of major ions, nutrients, and pesticides in groundwater samples collected in the Anacostia River and Rock Creek watersheds in Washington, D.C., August to September 2008, and selected water-quality standards.—Continued

[CASRN ${ }^{\circledR}$, Chemical Abstracts Service Registry Number; USGS, U.S. Geological Survey; $\mu \mathrm{S} / \mathrm{cm}$, microsiemens per centimeter at 25 degrees Celsius; mg/L, milligrams per liter; $\mu \mathrm{g} / \mathrm{L}$, micrograms per liter; ${ }^{\circ} \mathrm{C}$, degrees Celsius; NTU, nephelometric turbidity unit; gal/min, gallons per minute; $\mathrm{CaCO}_{3}$, calcium carbonate; $\mathrm{HCO}_{3}$, bicarbonate; $\mathrm{SiO}_{2}$, silicate; $\mathrm{SO}_{4}$, sulfate; $\mathrm{N}$, nitrogen; $\mathrm{P}$, phosphate; <, less than; --, no value available; na, not applicable; E, quantified above the long-term method detection limit (LT-MDL) but below the laboratory reporting level (LRL) with higher uncertainty; bold type, detected pesticide concentration; District of Columbia surface-water standards A, B, C, and D refer to different surface-water uses: A = primary contact recreation; B = secondary contact recreation and aesthetic enjoyment; $\mathrm{C}=$ protection and propagation of fish, shellfish, and wildlife; $\mathrm{D}=$ protection of human health related to consumption of fish and shellfish (District of Columbia, 2006); d, diluted sample, method high end of range exceeded; ***, refer to District of Columbia (2006) for this value]

\begin{tabular}{|c|c|c|c|c|c|c|c|c|}
\hline \multirow[b]{2}{*}{$\begin{array}{c}\text { USGS } \\
\text { site identifer }\end{array}$} & \multirow[b]{2}{*}{$\begin{array}{c}\text { USGS } \\
\text { well } \\
\text { identifer }\end{array}$} & \multicolumn{7}{|c|}{ Pesticides and pesticide degradates } \\
\hline & & $\begin{array}{c}\text { Diazinon } \\
(\mu \mathrm{g} / \mathrm{L})\end{array}$ & $\begin{array}{c}\text { Diazoxon } \\
(\mu \mathrm{g} / \mathrm{L})\end{array}$ & $\begin{array}{c}\text { Dicamba } \\
(\mu \mathrm{g} / \mathrm{L})\end{array}$ & $\begin{array}{c}\text { Dichlorprop } \\
\text { ( } \mu \mathrm{g} / \mathrm{L})\end{array}$ & $\begin{array}{c}\text { Dicrotophos } \\
(\mu \mathrm{g} / \mathrm{L})\end{array}$ & $\begin{array}{c}\text { Dieldrin } \\
\text { ( } \mu \mathrm{g} / \mathrm{L})\end{array}$ & $\begin{array}{l}\text { Dieldrin, } \\
\text { Method } 2 \\
(\mu \mathrm{g} / \mathrm{L})\end{array}$ \\
\hline \multicolumn{2}{|c|}{ CASRN $\circledast$} & $333-41-5$ & $962-58-3$ & $1918-00-9$ & $120-36-5$ & $141-66-2$ & $60-57-1$ & $60-57-1$ \\
\hline 385138076585902 & AC Aa 7 & $<.005$ & $<.01$ & $<.04$ & $<.02$ & $<.08$ & $<.009$ & $<.002$ \\
\hline 385649076584201 & WE Ba 11 & $<.005$ & $<.01$ & $<.04$ & $<.02$ & $<.08$ & 0.014 & 0.016 \\
\hline 385332076594701 & WE Ca 32 & $<.005$ & $<.01$ & $<.04$ & $<.02$ & $<.08$ & 0.026 & 0.028 \\
\hline 385245076583501 & WE Ca 34 & $<.005$ & $<.01$ & $<.04$ & $<.02$ & $<.08$ & $<.009$ & $<.002$ \\
\hline 385252076572801 & $\mathrm{WE} \mathrm{Cb} 8$ & $<.005$ & $<.01$ & $<.04$ & $<.02$ & $<.08$ & $<.009$ & $<.002$ \\
\hline 385644077061101 & WW Ba 28 & $<.005$ & $<.01$ & $<.04$ & $<.02$ & $<.08$ & $<.009$ & $<.002$ \\
\hline 385527077000701 & WW Bc 9 & $<.005$ & $<.01$ & $<.04$ & $<.02$ & $<.08$ & $<.009$ & $<.002$ \\
\hline 385619077020701 & WW Bc 10 & $<.005$ & $<.01$ & $<.04$ & $<.02$ & $<.08$ & $<.009$ & $<.002$ \\
\hline 385707077021801 & WW Bc 11 & $<.005$ & $<.01$ & $<.04$ & $<.02$ & $<.08$ & $<.009$ & $<.002$ \\
\hline \multicolumn{9}{|c|}{ Selected water-quality standards } \\
\hline $\begin{array}{l}\text { District of Columb } \\
\text { standards (Distr } \\
\text { 1993) }\end{array}$ & $\begin{array}{l}\text { groundwater } \\
\text { of Columbia, }\end{array}$ & -- & -- & -- & -- & -- & -- & -- \\
\hline \multicolumn{9}{|c|}{$\begin{array}{l}\text { District of Columbia surface- } \\
\text { water standards (District of } \\
\text { Columbia, 2006) }\end{array}$} \\
\hline $\begin{array}{l}\text { USEPA National P } \\
\text { Drinking Water } \\
\text { (U.S. Environme } \\
\text { Agency, 2009) }\end{array}$ & $\begin{array}{l}\text { mary } \\
\text { tandards } \\
\text { al Protection }\end{array}$ & -- & -- & -- & -- & -- & -- & -- \\
\hline
\end{tabular}


Table A1. Concentrations of major ions, nutrients, and pesticides in groundwater samples collected in the Anacostia River and Rock Creek watersheds in Washington, D.C., August to September 2008, and selected water-quality standards. - Continued

[CASRN®, Chemical Abstracts Service Registry Number; USGS, U.S. Geological Survey; $\mu \mathrm{S} / \mathrm{cm}$, microsiemens per centimeter at 25 degrees Celsius; mg/L, milligrams per liter; $\mu \mathrm{g} / \mathrm{L}$, micrograms per liter; ${ }^{\circ} \mathrm{C}$, degrees Celsius; NTU, nephelometric turbidity unit; gal $/ \mathrm{min}$, gallons per minute; $\mathrm{CaCO}_{3}$, calcium carbonate; $\mathrm{HCO}_{3}$, bicarbonate; $\mathrm{SiO}_{2}$, silicate; $\mathrm{SO}_{4}$, sulfate; $\mathrm{N}$, nitrogen; $\mathrm{P}$, phosphate; <, less than; --, no value available; na, not applicable; E, quantified above the long-term method detection limit (LT-MDL) but below the laboratory reporting level (LRL) with higher uncertainty; bold type, detected pesticide concentration; District of Columbia surface-water standards A, B, C, and D refer to different surface-water uses: A = primary contact recreation; B = secondary contact recreation and aesthetic enjoyment; $\mathrm{C}=$ protection and propagation of fish, shellfish, and wildlife; $\mathrm{D}=$ protection of human health related to consumption of fish and shellfish (District of Columbia, 2006); d, diluted sample, method high end of range exceeded; ***, refer to District of Columbia (2006) for this value]

\begin{tabular}{|c|c|c|c|c|c|c|c|c|c|}
\hline \multirow[b]{2}{*}{$\begin{array}{c}\text { USGS } \\
\text { site identifer }\end{array}$} & \multirow[b]{2}{*}{$\begin{array}{c}\text { USGS } \\
\text { well } \\
\text { identifer }\end{array}$} & \multicolumn{8}{|c|}{ Pesticides and pesticide degradates } \\
\hline & & $\begin{array}{l}\text { Dimetho- } \\
\text { ate } \\
(\mu \mathrm{g} / \mathrm{L})\end{array}$ & $\begin{array}{c}\text { Dinoseb } \\
(\mu \mathrm{g} / \mathrm{L})\end{array}$ & $\begin{array}{l}\text { Diphena- } \\
\text { mid } \\
(\mu \mathrm{g} / \mathrm{L})\end{array}$ & $\begin{array}{l}\text { Disulfoton } \\
\text { sulfone } \\
(\mu \mathrm{g} / \mathrm{L})\end{array}$ & $\begin{array}{l}\text { Disulfoton } \\
(\mu \mathrm{g} / \mathrm{L})\end{array}$ & $\begin{array}{c}\text { Diuron } \\
\text { ( } \mu \mathrm{g} / \mathrm{L})\end{array}$ & $\begin{array}{l}\text { Endosulfan } \\
\text { sulfate } \\
(\mu \mathrm{g} / \mathrm{L})\end{array}$ & $\begin{array}{l}\text { Endrin } \\
(\mu \mathrm{g} / \mathrm{L})\end{array}$ \\
\hline \multicolumn{2}{|c|}{ CASRN $\circledast$} & $60-51-5$ & $88-85-7$ & $957-51-7$ & $2497-06-5$ & $298-04-4$ & $330-54-1$ & $1031-07-8$ & $72-20-8$ \\
\hline 385138076585902 & $\mathrm{AC} \mathrm{Aa} 7$ & $<.006$ & $<.04$ & $<.04$ & $<.01$ & $<.04$ & $<.04$ & $<.022$ & $<.002$ \\
\hline 385649076584201 & WE Ba 11 & $<.006$ & $<.04$ & $<.04$ & $<.01$ & $<.04$ & $<.04$ & $<.022$ & $<.002$ \\
\hline 385332076594701 & WE Ca 32 & $<.006$ & $<.04$ & $<.04$ & $<.01$ & $<.04$ & E.0016 & $<.022$ & $<.002$ \\
\hline 385245076583501 & WE Ca 34 & $<.006$ & $<.04$ & $<.04$ & $<.01$ & $<.04$ & $<.04$ & $<.022$ & $<.002$ \\
\hline 385252076572801 & WE Cb 8 & $<.006$ & $<.04$ & $<.04$ & $<.01$ & $<.04$ & $<.04$ & $<.022$ & $<.002$ \\
\hline 385644077061101 & WW Ba 28 & $<.006$ & $<.04$ & $<.04$ & $<.01$ & $<.04$ & $<.04$ & $<.022$ & $<.002$ \\
\hline 385527077000701 & WW Bc 9 & $<.006$ & $<.04$ & $<.04$ & $<.01$ & $<.04$ & $<.04$ & $<.022$ & $<.002$ \\
\hline 385619077020701 & WW Bc 10 & $<.006$ & $<.04$ & $<.04$ & $<.01$ & $<.04$ & $<.04$ & $<.022$ & $<.002$ \\
\hline 385707077021801 & WW Bc 11 & $<.006$ & $<.04$ & $<.04$ & $<.01$ & $<.04$ & $<.04$ & $<.022$ & $<.002$ \\
\hline \multicolumn{10}{|c|}{ Selected water-quality standards } \\
\hline $\begin{array}{l}\text { District of Columb } \\
\text { standards (Distr } \\
\text { 1993) }\end{array}$ & $\begin{array}{l}\text { groundwater } \\
\text { of Columbia, }\end{array}$ & -- & -- & -- & -- & -- & -- & -- & 0.2 \\
\hline \multicolumn{10}{|c|}{$\begin{array}{l}\text { District of Columbia surface- } \\
\text { water standards (District of } \\
\text { Columbia, 2006) }\end{array}$} \\
\hline $\begin{array}{l}\text { USEPA National P } \\
\text { Drinking Water } \\
\text { (U.S. Environme } \\
\text { Agency, 2009) }\end{array}$ & $\begin{array}{l}\text { mary } \\
\text { tandards } \\
\text { al Protection }\end{array}$ & -- & 7 & -- & -- & -- & -- & -- & 2 \\
\hline
\end{tabular}


Table A1. Concentrations of major ions, nutrients, and pesticides in groundwater samples collected in the Anacostia River and Rock Creek watersheds in Washington, D.C., August to September 2008, and selected water-quality standards.-Continued

[CASRN ${ }^{\circledR}$, Chemical Abstracts Service Registry Number; USGS, U.S. Geological Survey; $\mu \mathrm{S} / \mathrm{cm}$, microsiemens per centimeter at 25 degrees Celsius; mg/L, milligrams per liter; $\mu \mathrm{g} / \mathrm{L}$, micrograms per liter; ${ }^{\circ} \mathrm{C}$, degrees Celsius; $\mathrm{NTU}$, nephelometric turbidity unit; gal $/ \mathrm{min}$, gallons per minute; $\mathrm{CaCO}_{3}$, calcium carbonate; $\mathrm{HCO}_{3}$, bicarbonate; $\mathrm{SiO}_{2}$, silicate; $\mathrm{SO}_{4}$, sulfate; $\mathrm{N}$, nitrogen; $\mathrm{P}$, phosphate; <, less than; --, no value available; na, not applicable; E, quantified above the long-term method detection limit (LT-MDL) but below the laboratory reporting level (LRL) with higher uncertainty; bold type, detected pesticide concentration; District of Columbia surface-water standards A, B, C, and D refer to different surface-water uses: A = primary contact recreation; B = secondary contact recreation and aesthetic enjoyment; $\mathrm{C}=$ protection and propagation of fish, shellfish, and wildlife; $\mathrm{D}=$ protection of human health related to consumption of fish and shellfish (District of Columbia, 2006); d, diluted sample, method high end of range exceeded; ***, refer to District of Columbia (2006) for this value]

\begin{tabular}{|c|c|c|c|c|c|c|c|c|}
\hline $\begin{array}{c}\text { USGS } \\
\text { site identifer }\end{array}$ & $\begin{array}{c}\text { USGS } \\
\text { well } \\
\text { identifer }\end{array}$ & \multicolumn{7}{|c|}{ Pesticides and pesticide degradates } \\
\hline 385138076585902 & AC Aa 7 & $<.002$ & $<.02$ & $<.006$ & $<.012$ & $<.053$ & $<.20$ & $<.03$ \\
\hline 385138076585901 & AC Aa 6 & $<.002$ & $<.02$ & $<.006$ & $<.012$ & $<.053$ & $<.20$ & $<.03$ \\
\hline 385606076584101 & WE Ba 9 & $<.002$ & $<.02$ & $<.006$ & $<.012$ & $<.053$ & $<.20$ & $<.03$ \\
\hline 385649076584201 & WE Ba 11 & $<.002$ & $<.02$ & $<.006$ & $<.012$ & $<.053$ & $<.20$ & $<.03$ \\
\hline 385332076594701 & WE Ca 32 & $<.002$ & $<.02$ & $<.006$ & $<.012$ & $<.053$ & $<.20$ & $<.03$ \\
\hline 385327076544801 & WE Cc 3 & $<.002$ & $<.02$ & $<.006$ & $<.012$ & $<.053$ & $<.20$ & $<.03$ \\
\hline 385929077020901 & WW Ac 8 & $<.002$ & $<.02$ & $<.006$ & $<.012$ & $<.053$ & $<.20$ & $<.03$ \\
\hline 385644077061101 & WW Ba 28 & $<.002$ & $<.02$ & $<.006$ & $<.012$ & $<.053$ & $<.20$ & $<.03$ \\
\hline 385527077000701 & WW Bc 9 & $<.002$ & $<.02$ & $<.006$ & $<.012$ & $<.053$ & $<.20$ & $<.03$ \\
\hline 385619077020701 & WW Bc 10 & $<.002$ & $<.02$ & $<.006$ & $<.012$ & $<.053$ & $<.20$ & $<.03$ \\
\hline 385707077021801 & WW Bc 11 & $<.002$ & $<.02$ & $<.006$ & $<.012$ & $<.053$ & $<.20$ & $<.03$ \\
\hline \multicolumn{9}{|c|}{ Selected water-quality standards } \\
\hline \multicolumn{2}{|c|}{$\begin{array}{l}\text { District of Columbia groundwater } \\
\text { standards (District of Columbia, } \\
\text { 1993) }\end{array}$} & -- & -- & -- & -- & -- & -- & -- \\
\hline \multicolumn{9}{|c|}{$\begin{array}{l}\text { District of Columbia surface- } \\
\text { water standards (District of } \\
\text { Columbia, 2006) }\end{array}$} \\
\hline C & & -- & -- & -- & -- & -- & -- & -- \\
\hline D & & -- & -- & -- & -- & -- & -- & -- \\
\hline \multicolumn{2}{|c|}{$\begin{array}{l}\text { USEPA National Primary } \\
\text { Drinking Water Standards } \\
\text { (U.S. Environmental Protection } \\
\text { Agency, 2009) }\end{array}$} & -- & -- & -- & -- & -- & -- & -- \\
\hline
\end{tabular}


Table A1. Concentrations of major ions, nutrients, and pesticides in groundwater samples collected in the Anacostia River and Rock Creek watersheds in Washington, D.C., August to September 2008, and selected water-quality standards. - Continued

[CASRN®, Chemical Abstracts Service Registry Number; USGS, U.S. Geological Survey; $\mu \mathrm{S} / \mathrm{cm}$, microsiemens per centimeter at 25 degrees Celsius; mg/L, milligrams per liter; $\mu \mathrm{g} / \mathrm{L}$, micrograms per liter; ${ }^{\circ} \mathrm{C}$, degrees Celsius; NTU, nephelometric turbidity unit; gal $/ \mathrm{min}$, gallons per minute; $\mathrm{CaCO}_{3}$, calcium carbonate; $\mathrm{HCO}_{3}$, bicarbonate; $\mathrm{SiO}_{2}$, silicate; $\mathrm{SO}_{4}$, sulfate; $\mathrm{N}$, nitrogen; $\mathrm{P}$, phosphate; <, less than; --, no value available; na, not applicable; E, quantified above the long-term method detection limit (LT-MDL) but below the laboratory reporting level (LRL) with higher uncertainty; bold type, detected pesticide concentration; District of Columbia surface-water standards A, B, C, and D refer to different surface-water uses: A = primary contact recreation; B = secondary contact recreation and aesthetic enjoyment; $\mathrm{C}=$ protection and propagation of fish, shellfish, and wildlife; $\mathrm{D}=$ protection of human health related to consumption of fish and shellfish (District of Columbia, 2006); d, diluted sample, method high end of range exceeded; ***, refer to District of Columbia (2006) for this value]

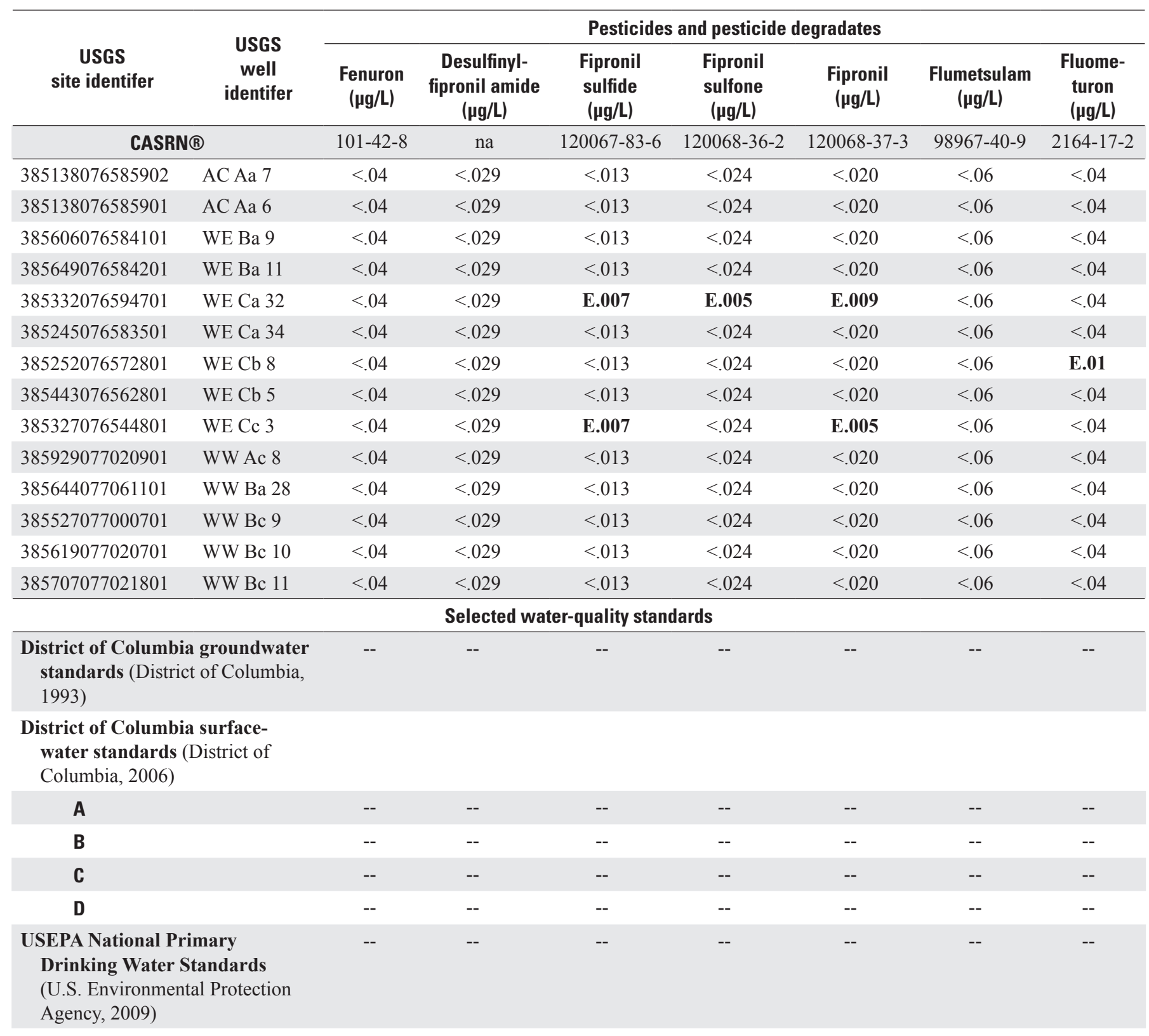


Table A1. Concentrations of major ions, nutrients, and pesticides in groundwater samples collected in the Anacostia River and Rock Creek watersheds in Washington, D.C., August to September 2008, and selected water-quality standards.-Continued

[CASRN ${ }^{\circledR}$, Chemical Abstracts Service Registry Number; USGS, U.S. Geological Survey; $\mu \mathrm{S} / \mathrm{cm}$, microsiemens per centimeter at 25 degrees Celsius; mg/L, milligrams per liter; $\mu \mathrm{g} / \mathrm{L}$, micrograms per liter; ${ }^{\circ} \mathrm{C}$, degrees Celsius; $\mathrm{NTU}$, nephelometric turbidity unit; gal $/ \mathrm{min}$, gallons per minute; $\mathrm{CaCO}_{3}$, calcium carbonate; $\mathrm{HCO}_{3}$, bicarbonate; $\mathrm{SiO}_{2}$, silicate; $\mathrm{SO}_{4}$, sulfate; $\mathrm{N}$, nitrogen; $\mathrm{P}$, phosphate; <, less than; --, no value available; na, not applicable; E, quantified above the long-term method detection limit (LT-MDL) but below the laboratory reporting level (LRL) with higher uncertainty; bold type, detected pesticide concentration; District of Columbia surface-water standards A, B, C, and D refer to different surface-water uses: A = primary contact recreation; B = secondary contact recreation and aesthetic enjoyment; $\mathrm{C}=$ protection and propagation of fish, shellfish, and wildlife; $\mathrm{D}=$ protection of human health related to consumption of fish and shellfish (District of Columbia, 2006); d, diluted sample, method high end of range exceeded; ***, refer to District of Columbia (2006) for this value]

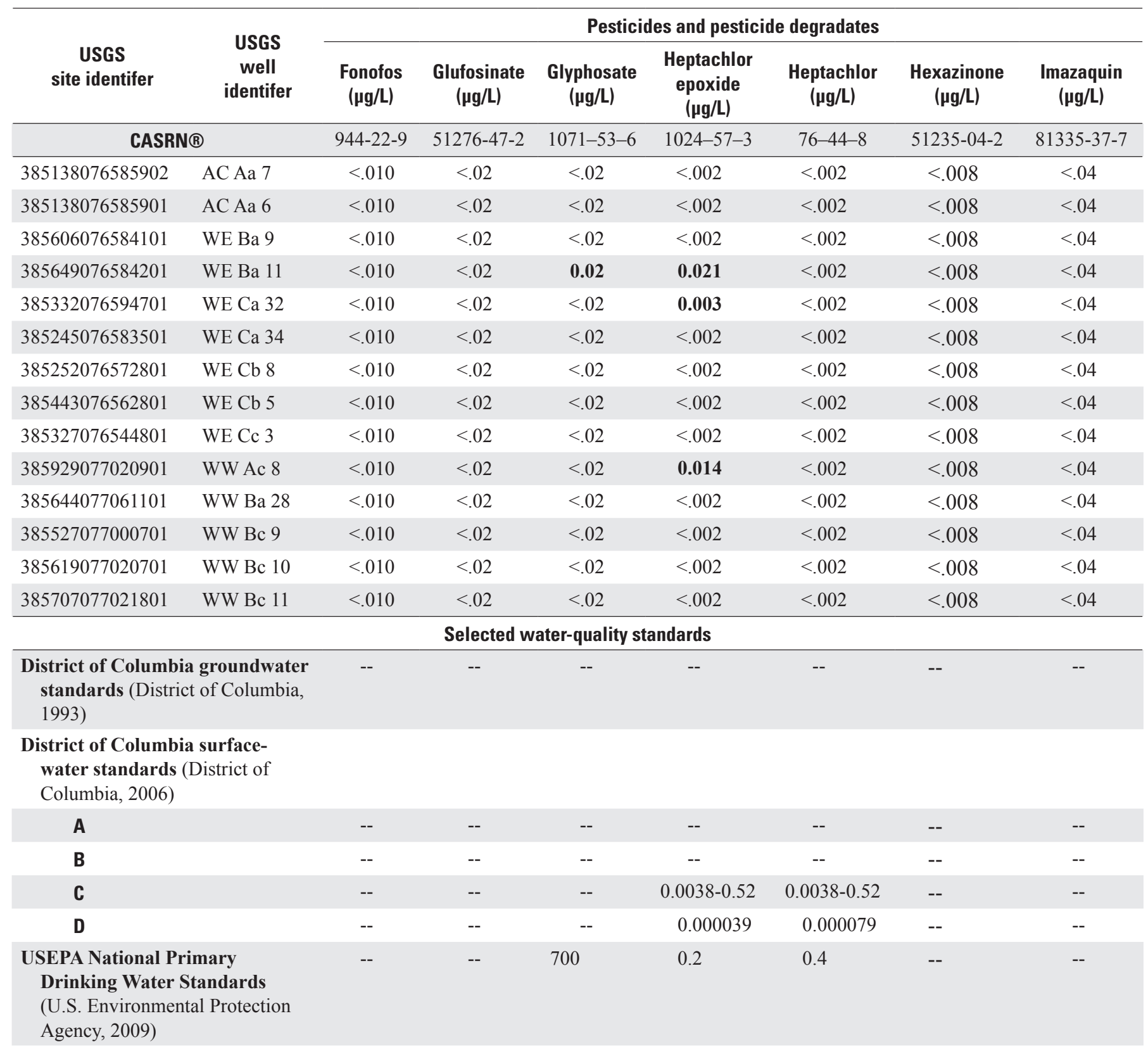


Table A1. Concentrations of major ions, nutrients, and pesticides in groundwater samples collected in the Anacostia River and Rock Creek watersheds in Washington, D.C., August to September 2008, and selected water-quality standards. - Continued

[CASRN®, Chemical Abstracts Service Registry Number; USGS, U.S. Geological Survey; $\mu \mathrm{S} / \mathrm{cm}$, microsiemens per centimeter at 25 degrees Celsius; mg/L, milligrams per liter; $\mu \mathrm{g} / \mathrm{L}$, micrograms per liter; ${ }^{\circ} \mathrm{C}$, degrees Celsius; NTU, nephelometric turbidity unit; gal $/ \mathrm{min}$, gallons per minute; $\mathrm{CaCO}_{3}$, calcium carbonate; $\mathrm{HCO}_{3}$, bicarbonate; $\mathrm{SiO}_{2}$, silicate; $\mathrm{SO}_{4}$, sulfate; $\mathrm{N}$, nitrogen; $\mathrm{P}$, phosphate; <, less than; --, no value available; na, not applicable; E, quantified above the long-term method detection limit (LT-MDL) but below the laboratory reporting level (LRL) with higher uncertainty; bold type, detected pesticide concentration; District of Columbia surface-water standards A, B, C, and D refer to different surface-water uses: A = primary contact recreation; B = secondary contact recreation and aesthetic enjoyment; $\mathrm{C}=$ protection and propagation of fish, shellfish, and wildlife; $\mathrm{D}=$ protection of human health related to consumption of fish and shellfish (District of Columbia, 2006); d, diluted sample, method high end of range exceeded; ***, refer to District of Columbia (2006) for this value]

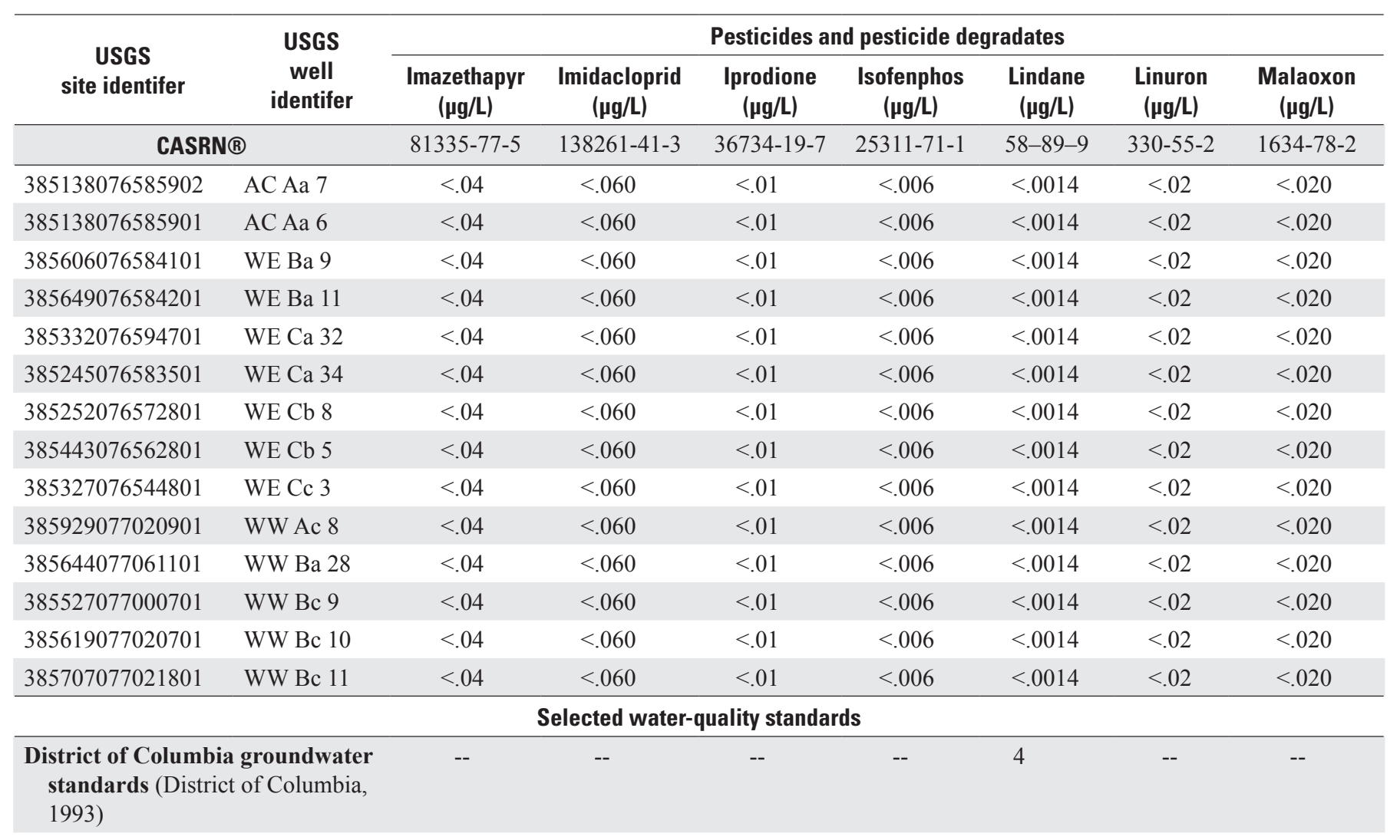

District of Columbia surface-

water standards (District of Columbia, 2006)

\begin{tabular}{|c|c|c|c|c|c|c|c|}
\hline A & -- & -- & -- & -- & -- & -- & -- \\
\hline B & -- & -- & -- & -- & -- & -- & -- \\
\hline C & -- & -- & -- & -- & $0.08-0.95$ & -- & -- \\
\hline $\begin{array}{l}\text { USEPA National Primary } \\
\text { Drinking Water Standards } \\
\text { (U.S. Environmental Protection } \\
\text { Agency, 2009) }\end{array}$ & -- & -- & -- & -- & 0.2 & -- & -- \\
\hline
\end{tabular}


Table A1. Concentrations of major ions, nutrients, and pesticides in groundwater samples collected in the Anacostia River and Rock Creek watersheds in Washington, D.C., August to September 2008, and selected water-quality standards.—Continued

[CASRN $®$, Chemical Abstracts Service Registry Number; USGS, U.S. Geological Survey; $\mu \mathrm{S} / \mathrm{cm}$, microsiemens per centimeter at 25 degrees Celsius; mg/L, milligrams per liter; $\mu \mathrm{g} / \mathrm{L}$, micrograms per liter; ${ }^{\circ} \mathrm{C}$, degrees Celsius; NTU, nephelometric turbidity unit; gal/min, gallons per minute; $\mathrm{CaCO}_{3}$, calcium carbonate; $\mathrm{HCO}_{3}$, bicarbonate; $\mathrm{SiO}_{2}$, silicate; $\mathrm{SO}_{4}$, sulfate; $\mathrm{N}$, nitrogen; $\mathrm{P}$, phosphate; <, less than; --, no value available; na, not applicable; E, quantified above the long-term method detection limit (LT-MDL) but below the laboratory reporting level (LRL) with higher uncertainty; bold type, detected pesticide concentration; District of Columbia surface-water standards A, B, C, and D refer to different surface-water uses: A = primary contact recreation; B = secondary contact recreation and aesthetic enjoyment; $\mathrm{C}=$ protection and propagation of fish, shellfish, and wildlife; $\mathrm{D}=$ protection of human health related to consumption of fish and shellfish (District of Columbia, 2006); d, diluted sample, method high end of range exceeded; ***, refer to District of Columbia (2006) for this value]

\begin{tabular}{|c|c|c|c|c|c|c|c|c|}
\hline $\begin{array}{c}\text { USGS } \\
\text { site identifer }\end{array}$ & $\begin{array}{c}\text { USGS } \\
\text { well } \\
\text { identifer }\end{array}$ & \multicolumn{7}{|c|}{ Pesticides and pesticide degradates } \\
\hline \multicolumn{2}{|c|}{ CASRN® } & $121-75-5$ & $94-74-6$ & $94-81-5$ & $57837-19-1$ & $57837-19-1$ & $950-37-8$ & $2032-65-7$ \\
\hline 385138076585901 & AC Aa 6 & $<.016$ & $<.06$ & $<.06$ & $<.02$ & $<.007$ & $<.004$ & $<.040$ \\
\hline 385606076584101 & WE Ba 9 & $<.016$ & $<.06$ & $<.06$ & $<.02$ & $<.007$ & $<.004$ & $<.040$ \\
\hline 385649076584201 & WE Ba 11 & $<.016$ & $<.06$ & $<.06$ & $<.02$ & $<.007$ & $<.004$ & $<.040$ \\
\hline 385332076594701 & WE Ca 32 & $<.016$ & $<.06$ & $<.06$ & $<.02$ & $<.008$ & $<.004$ & $<.040$ \\
\hline 385327076544801 & WE Cc 3 & $<.016$ & $<.06$ & $<.06$ & $<.02$ & $<.015$ & $<.004$ & $<.040$ \\
\hline 385929077020901 & WW Ac 8 & $<.016$ & $<.06$ & $<.06$ & $<.02$ & $<.007$ & $<.004$ & $<.040$ \\
\hline 385644077061101 & WW Ba 28 & $<.016$ & $<.06$ & $<.06$ & $<.02$ & $<.007$ & $<.004$ & $<.040$ \\
\hline 385527077000701 & WW Bc 9 & $<.016$ & $<.06$ & $<.06$ & $<.02$ & $<.007$ & $<.004$ & $<.040$ \\
\hline 385619077020701 & WW Bc 10 & $<.016$ & $<.06$ & $<.06$ & $<.02$ & $<.007$ & $<.004$ & $<.040$ \\
\hline 385707077021801 & WW Bc 11 & $<.016$ & $<.06$ & $<.06$ & $<.02$ & $<.015$ & $<.004$ & $<.040$ \\
\hline \multicolumn{9}{|c|}{ Selected water-quality standards } \\
\hline $\begin{array}{l}\text { District of Columb } \\
\text { standards (Distr } \\
\text { 1993) }\end{array}$ & $\begin{array}{l}\text { groundwater } \\
\text { of Columbia, }\end{array}$ & -- & -- & -- & -- & -- & -- & -- \\
\hline D & & -- & -- & -- & -- & -- & -- & -- \\
\hline \multicolumn{2}{|c|}{$\begin{array}{l}\text { USEPA National Primary } \\
\text { Drinking Water Standards } \\
\text { (U.S. Environmental Protection } \\
\text { Agency, 2009) }\end{array}$} & -- & -- & -- & -- & -- & -- & -- \\
\hline
\end{tabular}


Table A1. Concentrations of major ions, nutrients, and pesticides in groundwater samples collected in the Anacostia River and Rock Creek watersheds in Washington, D.C., August to September 2008, and selected water-quality standards. - Continued

[CASRN®, Chemical Abstracts Service Registry Number; USGS, U.S. Geological Survey; $\mu \mathrm{S} / \mathrm{cm}$, microsiemens per centimeter at 25 degrees Celsius; mg/L, milligrams per liter; $\mu \mathrm{g} / \mathrm{L}$, micrograms per liter; ${ }^{\circ} \mathrm{C}$, degrees Celsius; NTU, nephelometric turbidity unit; gal $/ \mathrm{min}$, gallons per minute; $\mathrm{CaCO}_{3}$, calcium carbonate; $\mathrm{HCO}_{3}$, bicarbonate; $\mathrm{SiO}_{2}$, silicate; $\mathrm{SO}_{4}$, sulfate; $\mathrm{N}$, nitrogen; $\mathrm{P}$, phosphate; <, less than; --, no value available; na, not applicable; $\mathrm{E}$, quantified above the long-term method detection limit (LT-MDL) but below the laboratory reporting level (LRL) with higher uncertainty; bold type, detected pesticide concentration; District of Columbia surface-water standards A, B, C, and D refer to different surface-water uses: A = primary contact recreation; B = secondary contact recreation and aesthetic enjoyment; $\mathrm{C}=$ protection and propagation of fish, shellfish, and wildlife; $\mathrm{D}=$ protection of human health related to consumption of fish and shellfish (District of Columbia, 2006); d, diluted sample, method high end of range exceeded; ***, refer to District of Columbia (2006) for this value]

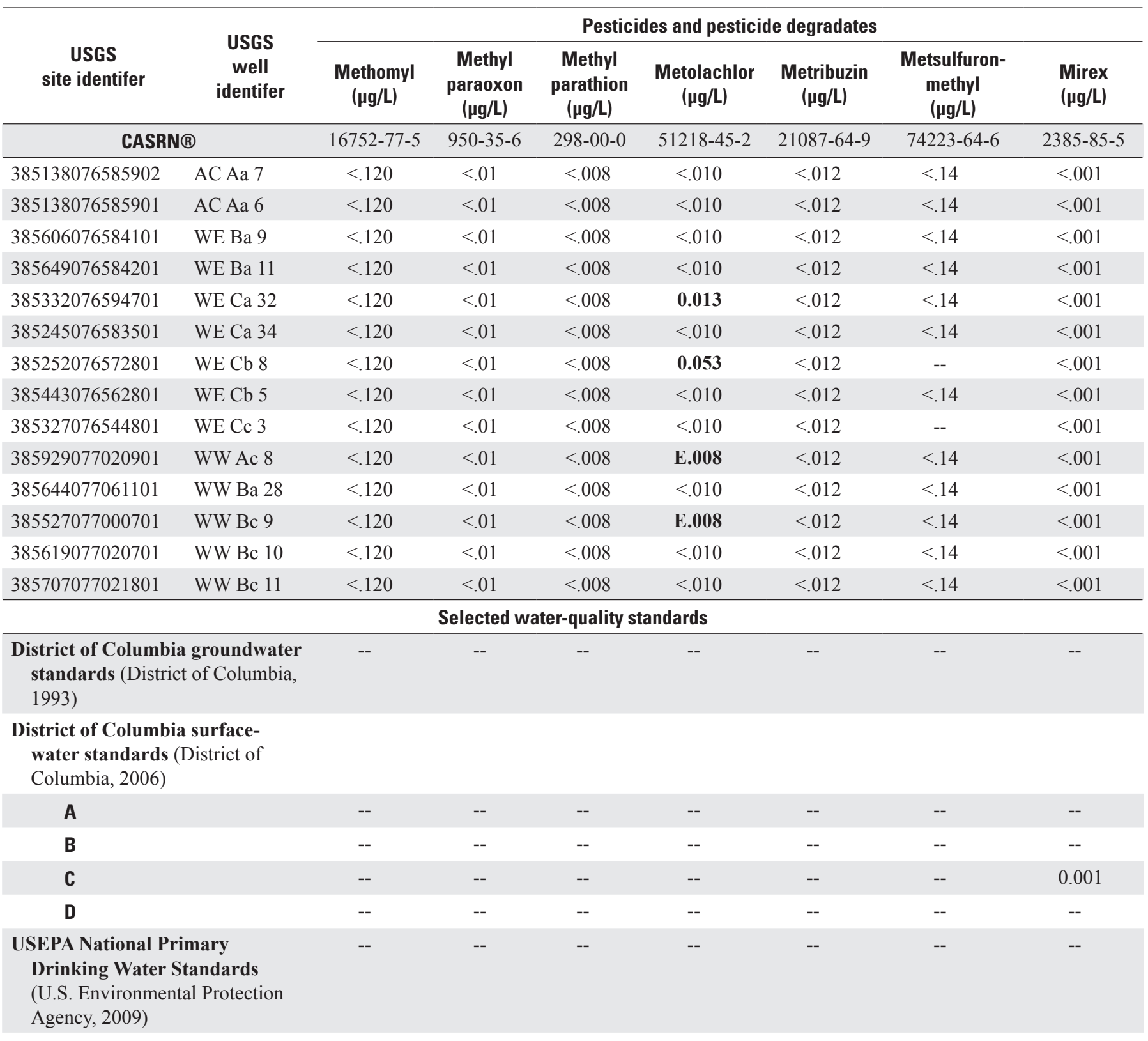


Table A1. Concentrations of major ions, nutrients, and pesticides in groundwater samples collected in the Anacostia River and Rock Creek watersheds in Washington, D.C., August to September 2008, and selected water-quality standards.—Continued

[CASRN ${ }^{\circledR}$, Chemical Abstracts Service Registry Number; USGS, U.S. Geological Survey; $\mu \mathrm{S} / \mathrm{cm}$, microsiemens per centimeter at 25 degrees Celsius; mg/L, milligrams per liter; $\mu \mathrm{g} / \mathrm{L}$, micrograms per liter; ${ }^{\circ} \mathrm{C}$, degrees Celsius; NTU, nephelometric turbidity unit; gal/min, gallons per minute; $\mathrm{CaCO}_{3}$, calcium carbonate; $\mathrm{HCO}_{3}$, bicarbonate; $\mathrm{SiO}_{2}$, silicate; $\mathrm{SO}_{4}$, sulfate; $\mathrm{N}$, nitrogen; $\mathrm{P}$, phosphate; <, less than; --, no value available; na, not applicable; E, quantified above the long-term method detection limit (LT-MDL) but below the laboratory reporting level (LRL) with higher uncertainty; bold type, detected pesticide concentration; District of Columbia surface-water standards A, B, C, and D refer to different surface-water uses: A = primary contact recreation; B = secondary contact recreation and aesthetic enjoyment; $\mathrm{C}=$ protection and propagation of fish, shellfish, and wildlife; $\mathrm{D}=$ protection of human health related to consumption of fish and shellfish (District of Columbia, 2006); d, diluted sample, method high end of range exceeded; ***, refer to District of Columbia (2006) for this value]

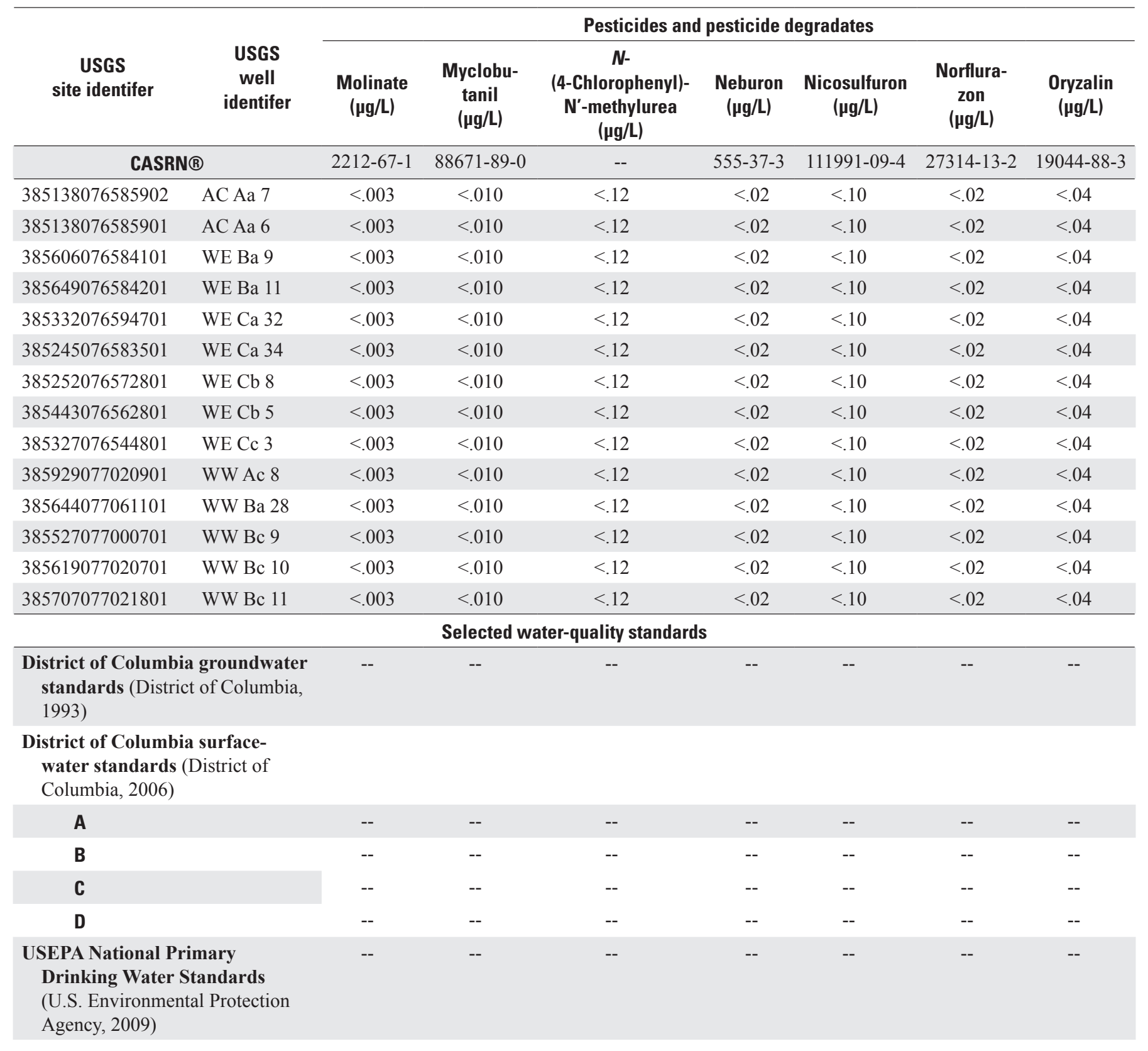


Table A1. Concentrations of major ions, nutrients, and pesticides in groundwater samples collected in the Anacostia River and Rock Creek watersheds in Washington, D.C., August to September 2008, and selected water-quality standards. - Continued

[CASRN®, Chemical Abstracts Service Registry Number; USGS, U.S. Geological Survey; $\mu \mathrm{S} / \mathrm{cm}$, microsiemens per centimeter at 25 degrees Celsius; mg/L, milligrams per liter; $\mu \mathrm{g} / \mathrm{L}$, micrograms per liter; ${ }^{\circ} \mathrm{C}$, degrees Celsius; NTU, nephelometric turbidity unit; gal $/ \mathrm{min}$, gallons per minute; $\mathrm{CaCO}_{3}$, calcium carbonate; $\mathrm{HCO}_{3}$, bicarbonate; $\mathrm{SiO}_{2}$, silicate; $\mathrm{SO}_{4}$, sulfate; N, nitrogen; $\mathrm{P}$, phosphate; <, less than; --, no value available; na, not applicable; E, quantified above the long-term method detection limit (LT-MDL) but below the laboratory reporting level (LRL) with higher uncertainty; bold type, detected pesticide concentration; District of Columbia surface-water standards A, B, C, and D refer to different surface-water uses: A = primary contact recreation; B = secondary contact recreation and aesthetic enjoyment; $\mathrm{C}=$ protection and propagation of fish, shellfish, and wildlife; $\mathrm{D}=$ protection of human health related to consumption of fish and shellfish (District of Columbia, 2006); d, diluted sample, method high end of range exceeded; ***, refer to District of Columbia (2006) for this value]

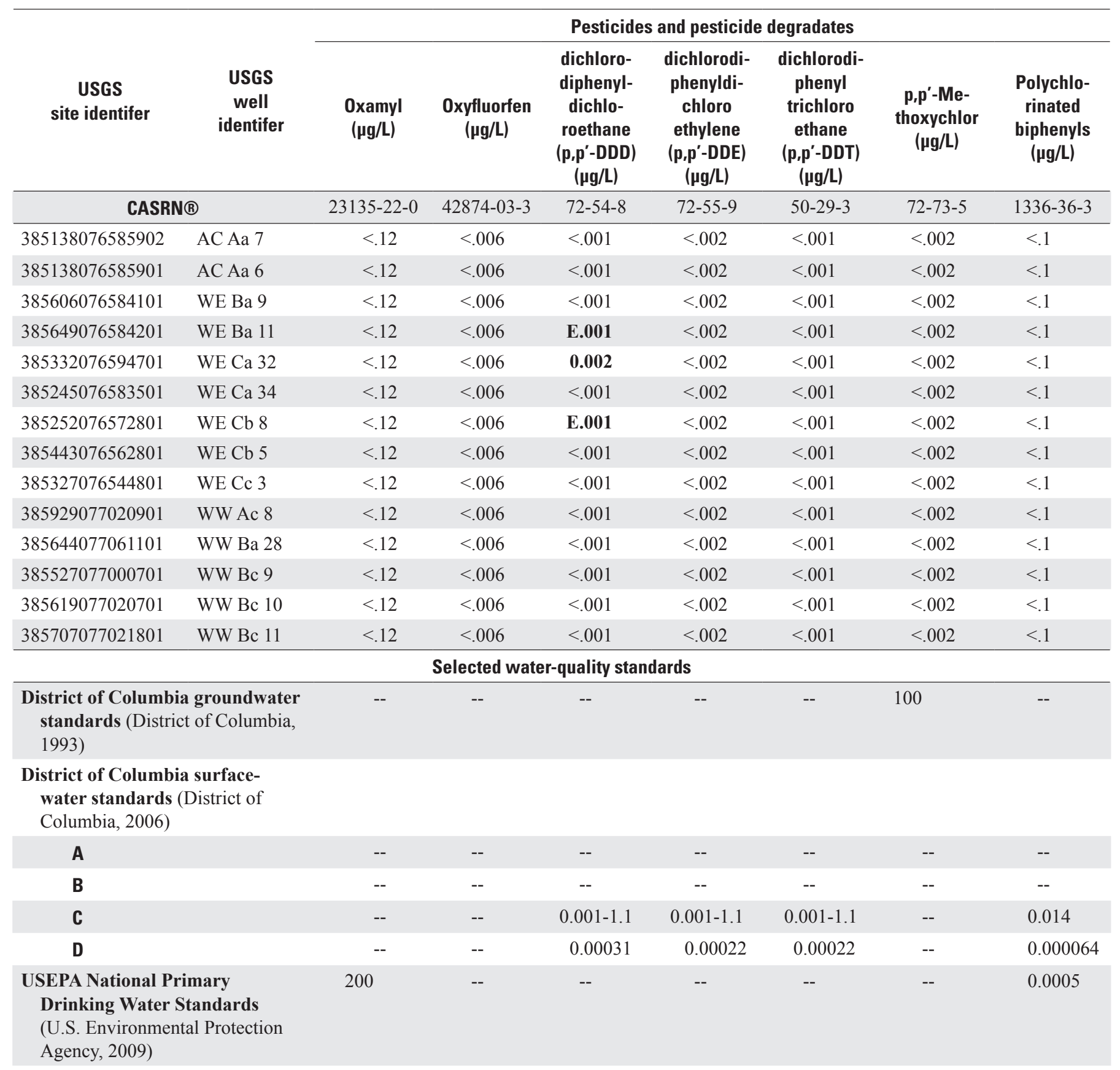


Table A1. Concentrations of major ions, nutrients, and pesticides in groundwater samples collected in the Anacostia River and Rock Creek watersheds in Washington, D.C., August to September 2008, and selected water-quality standards. - Continued

[CASRN ${ }^{\circledR}$, Chemical Abstracts Service Registry Number; USGS, U.S. Geological Survey; $\mu \mathrm{S} / \mathrm{cm}$, microsiemens per centimeter at 25 degrees Celsius; mg/L, milligrams per liter; $\mu \mathrm{g} / \mathrm{L}$, micrograms per liter; ${ }^{\circ} \mathrm{C}$, degrees Celsius; NTU, nephelometric turbidity unit; gal/min, gallons per minute; $\mathrm{CaCO}_{3}$, calcium carbonate; $\mathrm{HCO}_{3}$, bicarbonate; $\mathrm{SiO}_{2}$, silicate; $\mathrm{SO}_{4}$, sulfate; $\mathrm{N}$, nitrogen; $\mathrm{P}$, phosphate; <, less than; --, no value available; na, not applicable; E, quantified above the long-term method detection limit (LT-MDL) but below the laboratory reporting level (LRL) with higher uncertainty; bold type, detected pesticide concentration; District of Columbia surface-water standards A, B, C, and D refer to different surface-water uses: A = primary contact recreation; B = secondary contact recreation and aesthetic enjoyment; $\mathrm{C}=$ protection and propagation of fish, shellfish, and wildlife; $\mathrm{D}=$ protection of human health related to consumption of fish and shellfish (District of Columbia, 2006); d, diluted sample, method high end of range exceeded; ***, refer to District of Columbia (2006) for this value]

\begin{tabular}{|c|c|c|c|c|c|c|c|c|}
\hline $\begin{array}{c}\text { USGS } \\
\text { site identifer }\end{array}$ & $\begin{array}{c}\text { USGS } \\
\text { well } \\
\text { identifer }\end{array}$ & \multicolumn{7}{|c|}{ Pesticides and pesticide degradates } \\
\hline \multicolumn{2}{|c|}{ CASRN ${ }^{\circledR}$} & $40487-42-1$ & $2600-69-3$ & $298-02-2$ & $3735-33-9$ & $732-11-6$ & 1918-02-1 & $1610-18-0$ \\
\hline 385138076585902 & AC Aa 7 & $<.012$ & $<.03$ & $<.040$ & $<.05$ & $<.008$ & $<.12$ & $<.01$ \\
\hline 385649076584201 & WE Ba 11 & $<.012$ & $<.03$ & $<.040$ & $<.05$ & $<.008$ & $<.12$ & $<.01$ \\
\hline 385332076594701 & WE Ca 32 & $<.012$ & $<.03$ & $<.040$ & $<.05$ & $<.008$ & $<.12$ & E.01 \\
\hline 385245076583501 & WE Ca 34 & $<.012$ & $<.03$ & $<.040$ & $<.05$ & $<.008$ & $<.12$ & $<.01$ \\
\hline 385252076572801 & $\mathrm{WE} \mathrm{Cb} 8$ & $<.012$ & $<.03$ & $<.040$ & $<.05$ & $<.008$ & $<.12$ & $<.01$ \\
\hline 385644077061101 & WW Ba 28 & $<.012$ & $<.03$ & $<.040$ & $<.05$ & $<.008$ & $<.12$ & $<.01$ \\
\hline 385527077000701 & WW Bc 9 & $<.012$ & $<.03$ & $<.040$ & $<.05$ & $<.008$ & $<.12$ & $<.01$ \\
\hline 385619077020701 & WW Bc 10 & $<.012$ & $<.03$ & $<.040$ & $<.05$ & $<.008$ & $<.12$ & $<.01$ \\
\hline 385707077021801 & WW Bc 11 & $<.012$ & $<.03$ & $<.040$ & $<.05$ & $<.008$ & $<.12$ & $<.01$ \\
\hline \multicolumn{9}{|c|}{ Selected water-quality standards } \\
\hline $\begin{array}{l}\text { District of Columb } \\
\text { standards (Distr } \\
\text { 1993) }\end{array}$ & $\begin{array}{l}\text { groundwater } \\
\text { of Columbia, }\end{array}$ & -- & -- & -- & -- & -- & - & -- \\
\hline \multicolumn{9}{|c|}{$\begin{array}{l}\text { District of Columbia surface- } \\
\text { water standards (District of } \\
\text { Columbia, 2006) }\end{array}$} \\
\hline $\begin{array}{l}\text { USEPA National } P \\
\text { Drinking Water } \\
\text { (U.S. Environme } \\
\text { Agency, 2009) }\end{array}$ & $\begin{array}{l}\text { mary } \\
\text { tandards } \\
\text { al Protection }\end{array}$ & -- & -- & -- & -- & -- & 500 & -- \\
\hline
\end{tabular}


Table A1. Concentrations of major ions, nutrients, and pesticides in groundwater samples collected in the Anacostia River and Rock Creek watersheds in Washington, D.C., August to September 2008, and selected water-quality standards. - Continued

[CASRN®, Chemical Abstracts Service Registry Number; USGS, U.S. Geological Survey; $\mu \mathrm{S} / \mathrm{cm}$, microsiemens per centimeter at 25 degrees Celsius; mg/L, milligrams per liter; $\mu \mathrm{g} / \mathrm{L}$, micrograms per liter; ${ }^{\circ} \mathrm{C}$, degrees Celsius; NTU, nephelometric turbidity unit; gal $/ \mathrm{min}$, gallons per minute; $\mathrm{CaCO}_{3}$, calcium carbonate; $\mathrm{HCO}_{3}$, bicarbonate; $\mathrm{SiO}_{2}$, silicate; $\mathrm{SO}_{4}$, sulfate; $\mathrm{N}$, nitrogen; $\mathrm{P}$, phosphate; <, less than; --, no value available; na, not applicable; E, quantified above the long-term method detection limit (LT-MDL) but below the laboratory reporting level (LRL) with higher uncertainty; bold type, detected pesticide concentration; District of Columbia surface-water standards A, B, C, and D refer to different surface-water uses: A = primary contact recreation; B = secondary contact recreation and aesthetic enjoyment; $\mathrm{C}=$ protection and propagation of fish, shellfish, and wildlife; $\mathrm{D}=$ protection of human health related to consumption of fish and shellfish (District of Columbia, 2006); d, diluted sample, method high end of range exceeded; ***, refer to District of Columbia (2006) for this value]

\begin{tabular}{|c|c|c|c|c|c|c|c|c|}
\hline \multirow{2}{*}{$\begin{array}{c}\text { USGS } \\
\text { site identifer }\end{array}$} & \multirow{2}{*}{$\begin{array}{c}\text { USGS } \\
\text { well } \\
\text { identifer }\end{array}$} & \multicolumn{7}{|c|}{ Pesticides and pesticide degradates } \\
\hline & & $\begin{array}{l}\text { Prometryn } \\
(\mu \mathrm{g} / \mathrm{L})\end{array}$ & $\begin{array}{c}\text { Propyzamide } \\
(\mu \mathrm{g} / \mathrm{L})\end{array}$ & $\begin{array}{c}\text { Propanil } \\
(\mu \mathrm{g} / \mathrm{L})\end{array}$ & $\begin{array}{c}\text { Propargite } \\
(\mu \mathrm{g} / \mathrm{L})\end{array}$ & $\begin{array}{c}\text { Propham } \\
\text { ( } \mu \mathrm{g} / \mathrm{L})\end{array}$ & $\begin{array}{c}\text { Propiconazole } \\
(\mu \mathrm{g} / \mathrm{L})\end{array}$ & $\begin{array}{c}\text { Propoxur } \\
(\mu \mathrm{g} / \mathrm{L})\end{array}$ \\
\hline 385138076585902 & $\mathrm{AC}$ Aa 7 & $<.006$ & $<.004$ & $<.006$ & $<.04$ & $<.040$ & $<.04$ & $<.040$ \\
\hline 385138076585901 & AC Aa 6 & $<.006$ & $<.004$ & $<.006$ & $<.04$ & $<.040$ & $<.04$ & $<.040$ \\
\hline 385649076584201 & WE Ba 11 & $<.006$ & $<.004$ & $<.006$ & $<.04$ & $<.040$ & $<.04$ & $<.040$ \\
\hline 385332076594701 & WE Ca 32 & $<.006$ & $<.004$ & $<.006$ & $<.04$ & $<.040$ & $<.04$ & $<.040$ \\
\hline 385245076583501 & WE Ca 34 & $<.006$ & $<.004$ & $<.006$ & $<.04$ & $<.040$ & $<.04$ & $<.040$ \\
\hline 385252076572801 & WE $\mathrm{Cb} 8$ & $<.006$ & $<.004$ & $<.006$ & $<.04$ & $<.040$ & $<.04$ & $<.040$ \\
\hline 385443076562801 & WE Cb 5 & $<.006$ & $<.004$ & $<.006$ & $<.04$ & $<.040$ & $<.04$ & $<.040$ \\
\hline 385527077000701 & WW Bc 9 & $<.006$ & $<.004$ & $<.006$ & $<.04$ & $<.040$ & $<.04$ & $<.040$ \\
\hline 385619077020701 & WW Bc 10 & $<.006$ & $<.004$ & $<.006$ & $<.04$ & $<.040$ & $<.04$ & $<.040$ \\
\hline 385707077021801 & WW Bc 11 & $<.006$ & $<.004$ & $<.006$ & $<.04$ & $<.040$ & $<.04$ & $<.040$ \\
\hline \multicolumn{9}{|c|}{ Selected water-quality standards } \\
\hline $\begin{array}{l}\text { District of Columb } \\
\text { standards (Distri } \\
\text { 1993) }\end{array}$ & $\begin{array}{l}\text { groundwater } \\
\text { of Columbia, }\end{array}$ & -- & -- & -- & -- & -- & -- & -- \\
\hline \multicolumn{9}{|c|}{$\begin{array}{l}\text { District of Columbia surface- } \\
\text { water standards (District of } \\
\text { Columbia, 2006) }\end{array}$} \\
\hline
\end{tabular}


Table A1. Concentrations of major ions, nutrients, and pesticides in groundwater samples collected in the Anacostia River and Rock Creek watersheds in Washington, D.C., August to September 2008, and selected water-quality standards.—Continued

[CASRN ${ }^{\circledR}$, Chemical Abstracts Service Registry Number; USGS, U.S. Geological Survey; $\mu \mathrm{S} / \mathrm{cm}$, microsiemens per centimeter at 25 degrees Celsius; mg/L, milligrams per liter; $\mu \mathrm{g} / \mathrm{L}$, micrograms per liter; ${ }^{\circ} \mathrm{C}$, degrees Celsius; NTU, nephelometric turbidity unit; gal/min, gallons per minute; $\mathrm{CaCO}_{3}$, calcium carbonate; $\mathrm{HCO}_{3}$, bicarbonate; $\mathrm{SiO}_{2}$, silicate; $\mathrm{SO}_{4}$, sulfate; $\mathrm{N}$, nitrogen; $\mathrm{P}$, phosphate; <, less than; --, no value available; na, not applicable; E, quantified above the long-term method detection limit (LT-MDL) but below the laboratory reporting level (LRL) with higher uncertainty; bold type, detected pesticide concentration; District of Columbia surface-water standards A, B, C, and D refer to different surface-water uses: A = primary contact recreation; B = secondary contact recreation and aesthetic enjoyment; $\mathrm{C}=$ protection and propagation of fish, shellfish, and wildlife; $\mathrm{D}=$ protection of human health related to consumption of fish and shellfish (District of Columbia, 2006); d, diluted sample, method high end of range exceeded; ***, refer to District of Columbia (2006) for this value]

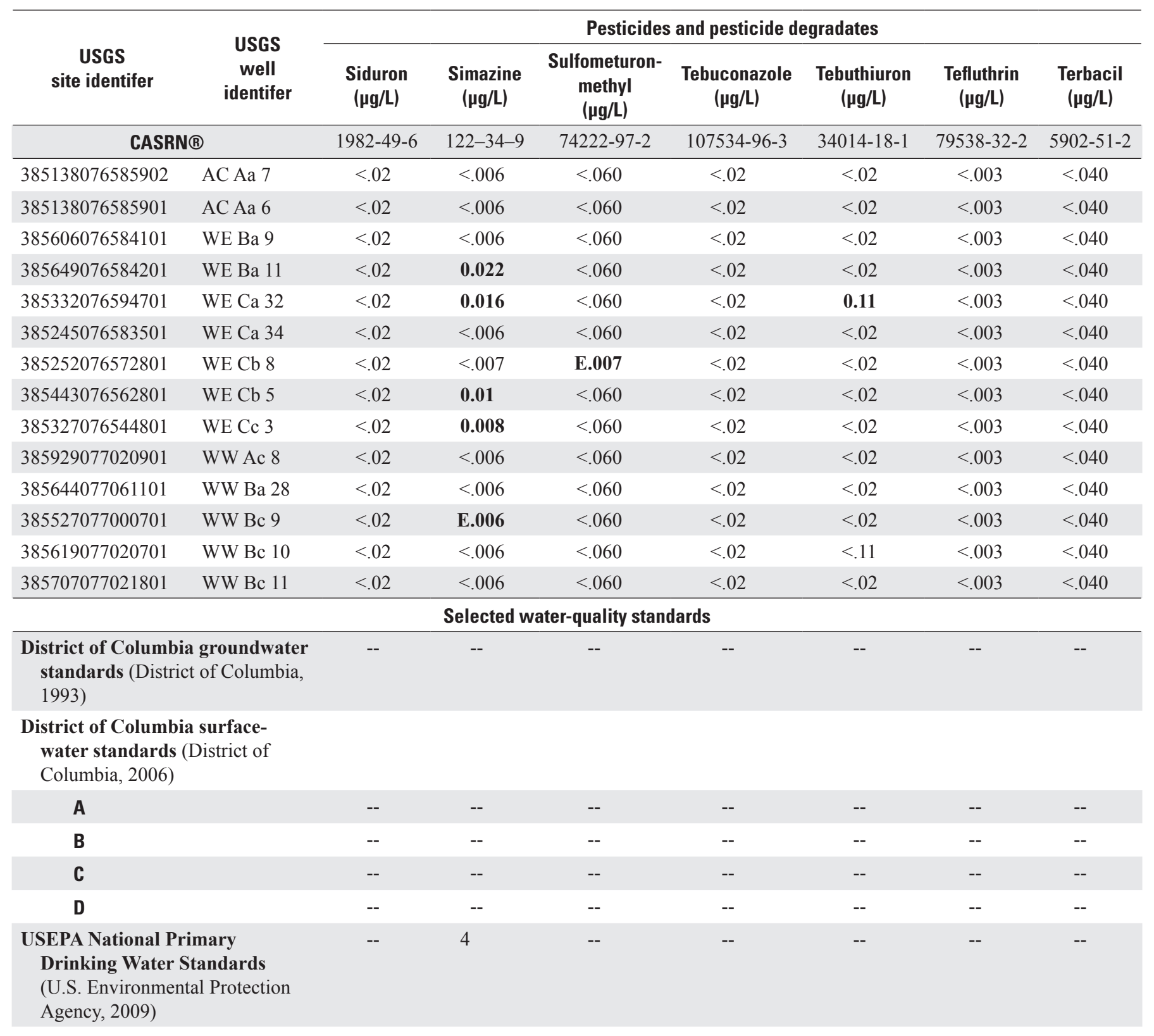


Table A1. Concentrations of major ions, nutrients, and pesticides in groundwater samples collected in the Anacostia River and Rock Creek watersheds in Washington, D.C., August to September 2008, and selected water-quality standards.-Continued

[CASRN®, Chemical Abstracts Service Registry Number; USGS, U.S. Geological Survey; $\mu \mathrm{S} / \mathrm{cm}$, microsiemens per centimeter at 25 degrees Celsius; mg/L, milligrams per liter; $\mu \mathrm{g} / \mathrm{L}$, micrograms per liter; ${ }^{\circ} \mathrm{C}$, degrees Celsius; NTU, nephelometric turbidity unit; gal $/ \mathrm{min}$, gallons per minute; $\mathrm{CaCO}_{3}$, calcium carbonate; $\mathrm{HCO}_{3}$, bicarbonate; $\mathrm{SiO}_{2}$, silicate; $\mathrm{SO}_{4}$, sulfate; $\mathrm{N}$, nitrogen; $\mathrm{P}$, phosphate; <, less than; --, no value available; na, not applicable; E, quantified above the long-term method detection limit (LT-MDL) but below the laboratory reporting level (LRL) with higher uncertainty; bold type, detected pesticide concentration; District of Columbia surface-water standards A, B, C, and D refer to different surface-water uses: A = primary contact recreation; B = secondary contact recreation and aesthetic enjoyment; $\mathrm{C}=$ protection and propagation of fish, shellfish, and wildlife; $\mathrm{D}=$ protection of human health related to consumption of fish and shellfish (District of Columbia, 2006); d, diluted sample, method high end of range exceeded; ***, refer to District of Columbia (2006) for this value]

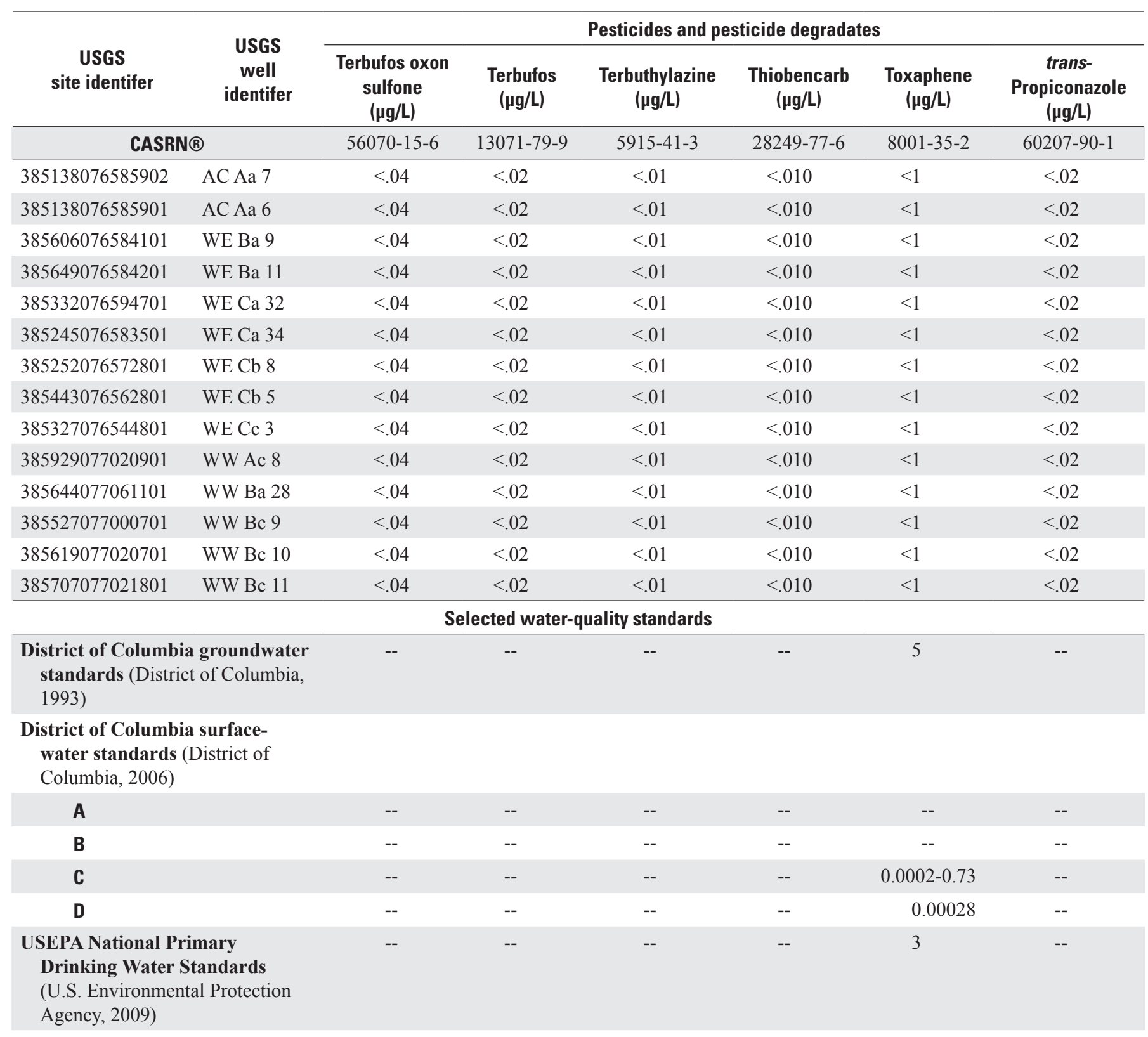


Table A1. Concentrations of major ions, nutrients, and pesticides in groundwater samples collected in the Anacostia River and Rock Creek watersheds in Washington, D.C., August to September 2008, and selected water-quality standards.—Continued

[CASRN ${ }^{\circledR}$, Chemical Abstracts Service Registry Number; USGS, U.S. Geological Survey; $\mu \mathrm{S} / \mathrm{cm}$, microsiemens per centimeter at 25 degrees Celsius; mg/L, milligrams per liter; $\mu \mathrm{g} / \mathrm{L}$, micrograms per liter; ${ }^{\circ} \mathrm{C}$, degrees Celsius; NTU, nephelometric turbidity unit; gal/min, gallons per minute; $\mathrm{CaCO}_{3}$, calcium carbonate; $\mathrm{HCO}_{3}$, bicarbonate; $\mathrm{SiO}_{2}$, silicate; $\mathrm{SO}_{4}$, sulfate; $\mathrm{N}$, nitrogen; $\mathrm{P}$, phosphate; <, less than; --, no value available; na, not applicable; E, quantified above the long-term method detection limit (LT-MDL) but below the laboratory reporting level (LRL) with higher uncertainty; bold type, detected pesticide concentration; District of Columbia surface-water standards A, B, C, and D refer to different surface-water uses: A = primary contact recreation; B = secondary contact recreation and aesthetic enjoyment; $\mathrm{C}=$ protection and propagation of fish, shellfish, and wildlife; $\mathrm{D}=$ protection of human health related to consumption of fish and shellfish (District of Columbia, 2006); d, diluted sample, method high end of range exceeded; ***, refer to District of Columbia (2006) for this value]

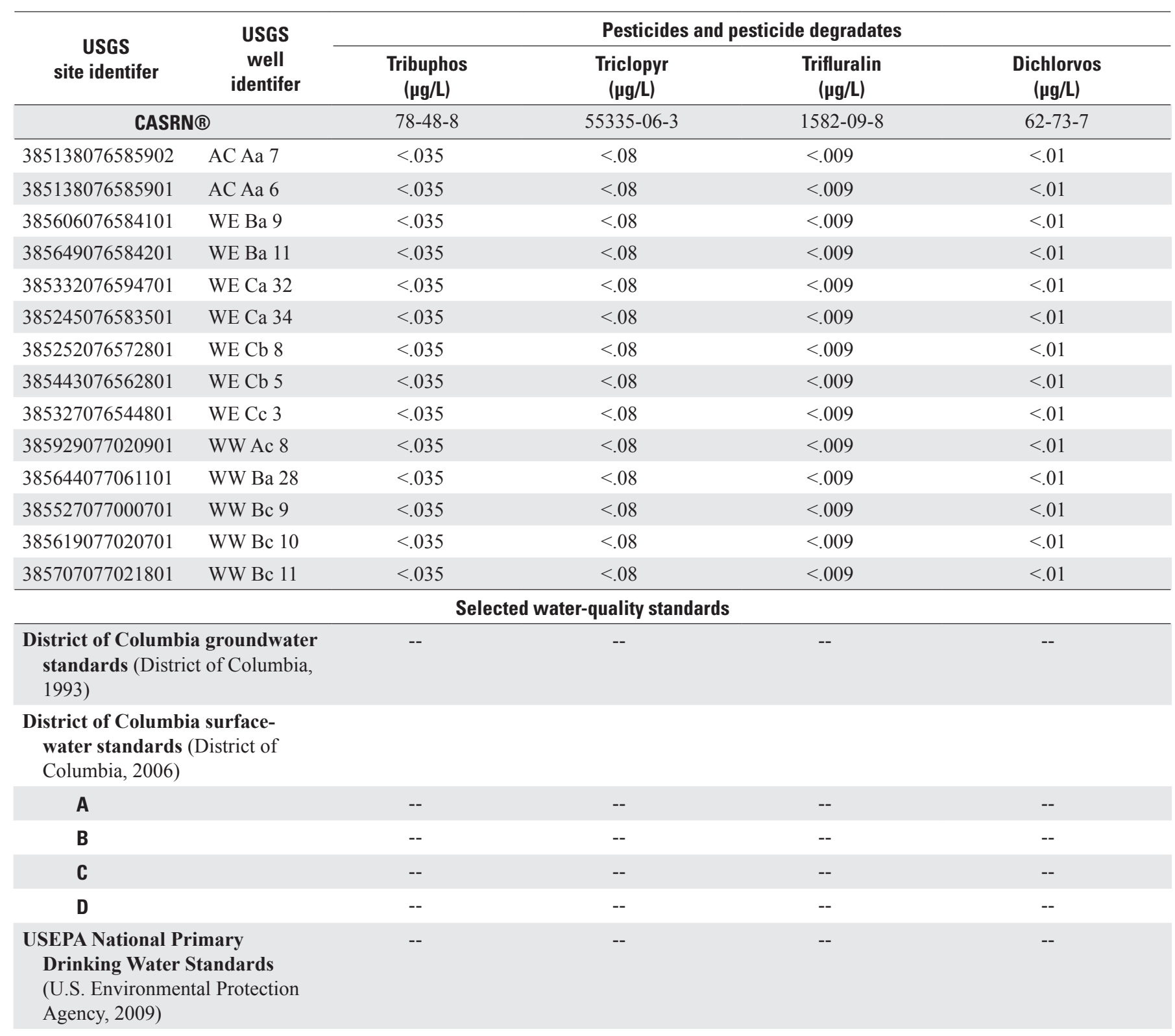


Table A1. Concentrations of major ions, nutrients, and pesticides in groundwater samples collected in the Anacostia River and Rock Creek watersheds in Washington, D.C., August to September 2008, and selected water-quality standards. - Continued

[CASRN®, Chemical Abstracts Service Registry Number; USGS, U.S. Geological Survey; $\mu \mathrm{S} / \mathrm{cm}$, microsiemens per centimeter at 25 degrees Celsius; mg/L, milligrams per liter; $\mu \mathrm{g} / \mathrm{L}$, micrograms per liter; ${ }^{\circ} \mathrm{C}$, degrees Celsius; NTU, nephelometric turbidity unit; gal $/ \mathrm{min}$, gallons per minute; $\mathrm{CaCO}_{3}$, calcium carbonate; $\mathrm{HCO}_{3}$, bicarbonate; $\mathrm{SiO}_{2}$, silicate; $\mathrm{SO}_{4}$, sulfate; $\mathrm{N}$, nitrogen; $\mathrm{P}$, phosphate; <, less than; --, no value available; na, not applicable; E, quantified above the long-term method detection limit (LT-MDL) but below the laboratory reporting level (LRL) with higher uncertainty; bold type, detected pesticide concentration; District of Columbia surface-water standards A, B, C, and D refer to different surface-water uses: A = primary contact recreation; B = secondary contact recreation and aesthetic enjoyment; $\mathrm{C}=$ protection and propagation of fish, shellfish, and wildlife; $\mathrm{D}=$ protection of human health related to consumption of fish and shellfish (District of Columbia, 2006); d, diluted sample, method high end of range exceeded; ***, refer to District of Columbia (2006) for this value]

\begin{tabular}{|c|c|c|c|c|c|}
\hline $\begin{array}{c}\text { USGS } \\
\text { site identifer }\end{array}$ & $\begin{array}{c}\text { USGS } \\
\text { well } \\
\text { identifer }\end{array}$ & \multicolumn{4}{|c|}{ Surrogates } \\
\hline \multicolumn{2}{|c|}{ CASRN® } & na & na & na & na \\
\hline 385138076585902 & AC Aa 7 & 67.4 & 90.9 & 78.9 & 98.2 \\
\hline 385649076584201 & WE Ba 11 & 94 & 118 & 91 & 91 \\
\hline 385332076594701 & WE Ca 32 & 62.2 & 95.7 & 80 & 94.9 \\
\hline 385245076583501 & WE Ca 34 & 62.6 & 86.8 & 76.6 & 53.4 \\
\hline 385252076572801 & $\mathrm{WE} \mathrm{Cb} 8$ & 80.1 & 113 & 98.1 & 85 \\
\hline 385644077061101 & WW Ba 28 & 87.4 & E114 & 85.4 & 78.2 \\
\hline 385527077000701 & WW Bc 9 & 66.8 & 87.9 & 91.7 & 102 \\
\hline 385619077020701 & WW Bc 10 & 75.1 & 98 & 76.8 & 38 \\
\hline 385707077021801 & WW Bc 11 & 87.4 & 95.8 & 96.4 & 81 \\
\hline \multicolumn{6}{|c|}{ Selected water-quality standards } \\
\hline \multicolumn{2}{|c|}{$\begin{array}{l}\text { District of Columbia groundwater } \\
\text { standards (District of Columbia, } \\
\text { 1993) }\end{array}$} & -- & -- & -- & -- \\
\hline \multicolumn{6}{|c|}{$\begin{array}{l}\text { District of Columbia surface- } \\
\text { water standards (District of } \\
\text { Columbia, 2006) }\end{array}$} \\
\hline \multicolumn{2}{|c|}{$\begin{array}{l}\text { USEPA National Primary } \\
\text { Drinking Water Standards } \\
\text { (U.S. Environmental Protection } \\
\text { Agency, 2009) }\end{array}$} & -- & -- & -- & -- \\
\hline
\end{tabular}


Table A1. Concentrations of major ions, nutrients, and pesticides in groundwater samples collected in the Anacostia River and Rock Creek watersheds in Washington, D.C., August to September 2008, and selected water-quality standards.—Continued

[CASRN ${ }^{\circledR}$, Chemical Abstracts Service Registry Number; USGS, U.S. Geological Survey; $\mu \mathrm{S} / \mathrm{cm}$, microsiemens per centimeter at 25 degrees Celsius; mg/L, milligrams per liter; $\mu \mathrm{g} / \mathrm{L}$, micrograms per liter; ${ }^{\circ} \mathrm{C}$, degrees Celsius; NTU, nephelometric turbidity unit; gal/min, gallons per minute; $\mathrm{CaCO}_{3}$, calcium carbonate; $\mathrm{HCO}_{3}$, bicarbonate; $\mathrm{SiO}_{2}$, silicate; $\mathrm{SO}_{4}$, sulfate; $\mathrm{N}$, nitrogen; $\mathrm{P}$, phosphate; <, less than; --, no value available; na, not applicable; E, quantified above the long-term method detection limit (LT-MDL) but below the laboratory reporting level (LRL with higher uncertainty; bold type, detected pesticide concentration; District of Columbia surface-water standards A, B, C, and D refer to different surface-water uses: A = primary contact recreation; B = secondary contact recreation and aesthetic enjoyment; $\mathrm{C}=$ protection and propagation of fish, shellfish, and wildlife; $\mathrm{D}=$ protection of human health related to consumption of fish and shellfish (District of Columbia, 2006); d, diluted sample, method high end of range exceeded; ***, refer to District of Columbia (2006) for this value]

\begin{tabular}{|c|c|c|c|c|c|}
\hline \multirow[b]{2}{*}{$\begin{array}{c}\text { USGS } \\
\text { site identifer }\end{array}$} & \multirow[b]{2}{*}{$\begin{array}{c}\text { USGS } \\
\text { well } \\
\text { identifer }\end{array}$} & \multicolumn{4}{|c|}{ Surrogates } \\
\hline & & $\begin{array}{l}\text { Caffeine-13C, surrogate, } \\
\text { Schedule } 2060 \\
\text { (percent recovery) }\end{array}$ & $\begin{array}{c}\text { Diazinon-d10, surrogate, } \\
\text { Schedule } 2033 \\
\text { (percent recovery) }\end{array}$ & $\begin{array}{l}\text { Isodrin, surrogate, } \\
\text { Schedule } 1398 \\
\text { (percent recovery) }\end{array}$ & $\begin{array}{l}\text { Polychlorinated biphe- } \\
\text { nyl 207, surrogate } \\
\text { (percent recovery) }\end{array}$ \\
\hline \multicolumn{2}{|c|}{ CASRN® } & na & na & na & na \\
\hline 385138076585902 & $\mathrm{AC} \mathrm{Aa} 7$ & 102 & 82.9 & 81.8 & 92.1 \\
\hline 385649076584201 & WE Ba 11 & 88.8 & 106 & 77.1 & 111 \\
\hline 385332076594701 & WE Ca 32 & 84.9 & 100 & 96.5 & 108 \\
\hline 385245076583501 & WE Ca 34 & 81.3 & 104 & 71.6 & 105 \\
\hline 385252076572801 & WE $\mathrm{Cb} 8$ & 88.3 & 117 & 86.7 & 117 \\
\hline 385644077061101 & WW Ba 28 & 87.8 & 128 & 88.7 & 111 \\
\hline 385527077000701 & WW Bc 9 & 95.1 & 107 & 79.7 & 104 \\
\hline 385619077020701 & WW Bc 10 & 67.9 & 199 & 86.5 & 108 \\
\hline 385707077021801 & WW Bc 11 & 80.6 & 126 & 96.8 & 106 \\
\hline \multicolumn{6}{|c|}{ Selected water-quality standards } \\
\hline $\begin{array}{l}\text { District of Columb } \\
\text { standards (Distr } \\
\text { 1993) }\end{array}$ & $\begin{array}{l}\text { groundwater } \\
\text { of Columbia, }\end{array}$ & -- & -- & -- & -- \\
\hline \multicolumn{6}{|c|}{$\begin{array}{l}\text { District of Columbia surface- } \\
\text { water standards (District of } \\
\text { Columbia, 2006) }\end{array}$} \\
\hline \multicolumn{2}{|c|}{$\begin{array}{l}\text { USEPA National Primary } \\
\text { Drinking Water Standards } \\
\text { U.S. Environmental Protection } \\
\text { Agency, 2009) }\end{array}$} & -- & -- & -- & -- \\
\hline
\end{tabular}




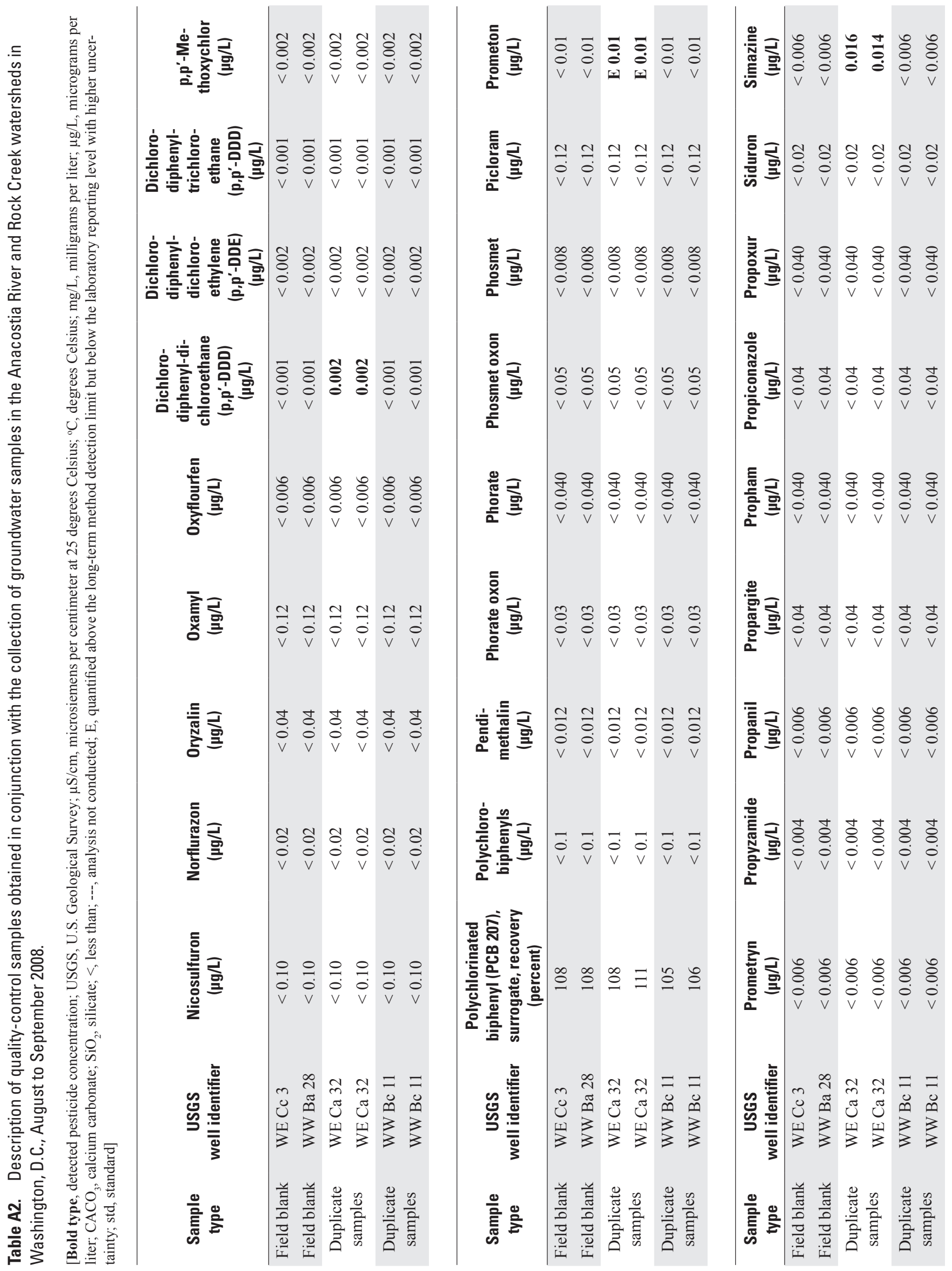




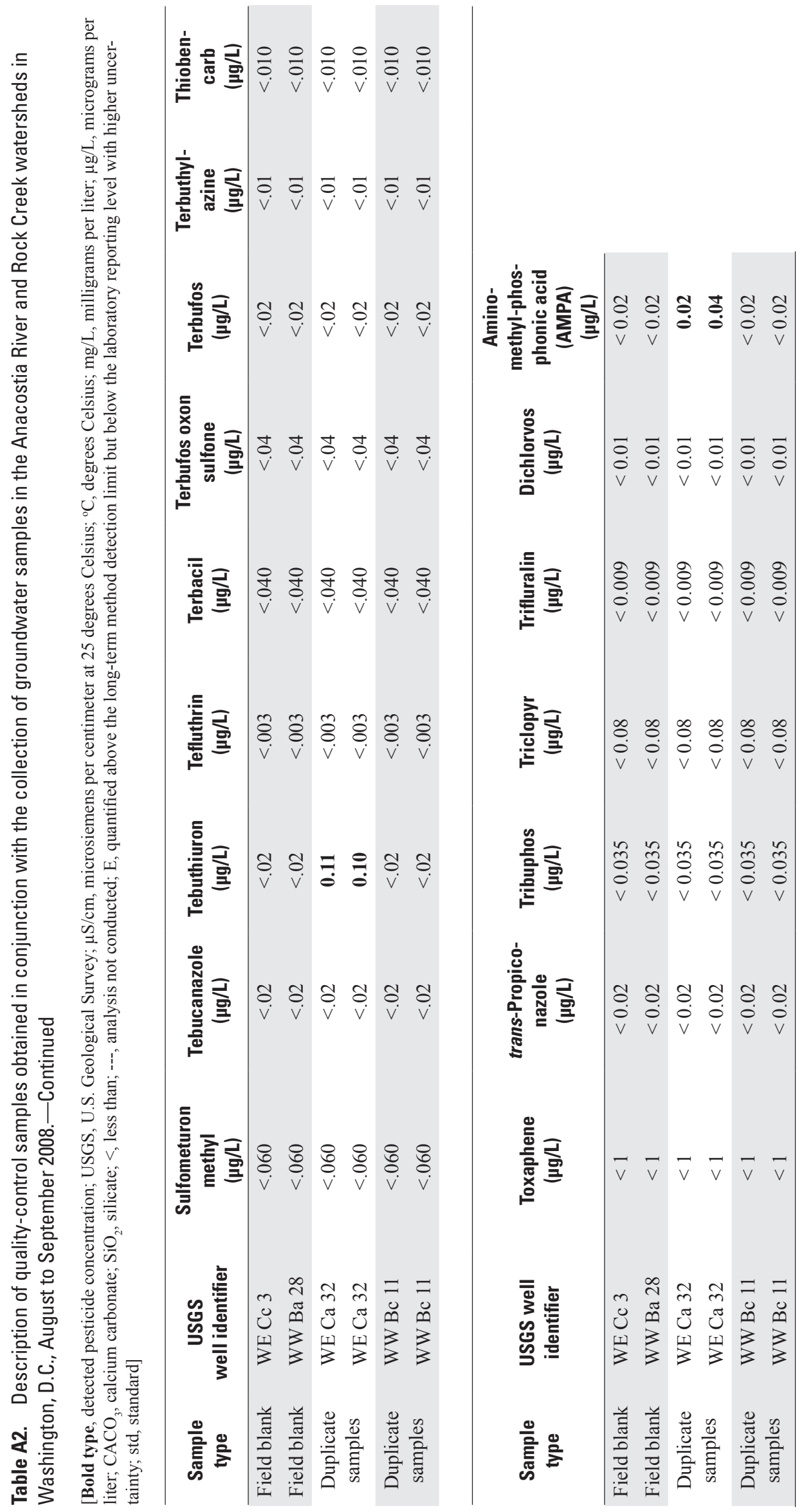




\section{Appendix B: Assessment of quality of data collected in 2005 and 2008}

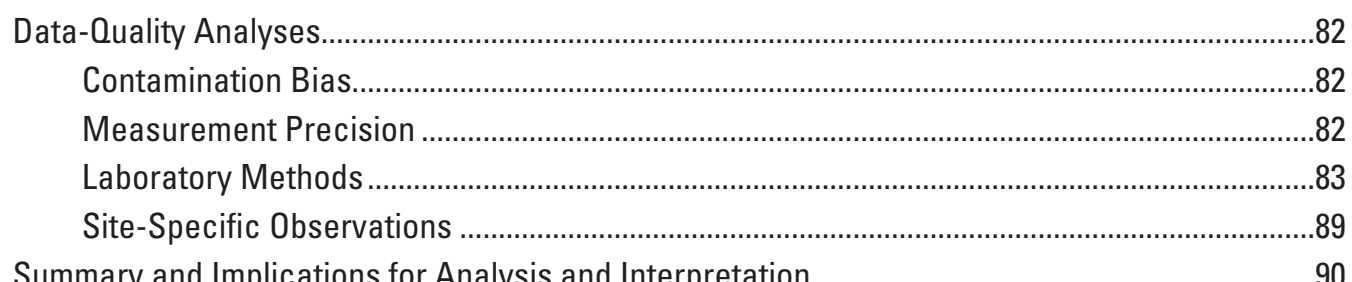

\section{Figures}

B1. Graphs showing relative percent difference as a function of mean concentration for: (A) Inorganic constituents (in milligrams per liter, $\mathrm{mg} / \mathrm{L}$ ), including calcium, magnesium, sodium, potassium, nitrate plus nitrite-nitrogen, ammonium-nitrogen, chloride, sulfate, manganese, and iron (with iron having the extreme value (40 percent) for one of two sets of duplicate measurements); and (B) pesticides (in micrograms per liter, $\mu \mathrm{g} / \mathrm{L})$, including atrazine, prometon, simazine, desethylatrazine, dieldrin, fipronil, fipronil sulfone, fipronil sulfide, aminomethylphosphonic acid (AMPA), heptachlor expoxide, metolachlor, dichlorodiphenyldiphenylethane $\left(p, p^{\prime}-D D E\right)$, and tebuthiuron

\section{Tables}

B1. Concentrations in field blanks and groundwater samples with constituents detected in at least one field blank collected during groundwater sampling in Washington, D.C. in 2008

B2. Means and relative percent differences in the concentrations of inorganic and organic constituents obtained from two sequential duplicate groundwater samples collected from wells in Washington, D.C. in 2008

B3. Mean and relative standard deviation of pesticide surrogate compound recoveries for each laboratory method and from laboratory-spiked groundwater samples in 2005 and 2008, and results of the Wilcoxon-Mann-Whitney rank sum test to determine if ranked recoveries in 2005 differed from ranked recoveries in 2008.

B4. U.S. Geological Survey laboratory reporting and detection levels for pesticide schedules used in 2005 and 2008, and for which at least one pesticide was detected in a groundwater sample in 2005 or 2008

B5. Pesticide detections and concentrations in groundwater samples collected from wells sampled in 2005 and 2008 and analyzed for similar compounds using the same laboratory schedules in 2005 and 2008.

B6. Pesticide detections in groundwater attributed to the addition of a laboratory schedule (LS 2033) in 2008 that was not used in 2005, or the addition of new pesticide compounds into laboratory schedules. 


\section{Data-Quality Analyses}

Pesticide data for this study were collected from 17 monitoring wells in the lower Anacostia River watershed in Washington, D.C. during fall 2005, and from 14 wells in the lower Anacostia River and Rock Creek watersheds in fall 2008. Some wells were previously installed and some were established for this project. Quality-control (QC) samples were collected with groundwater samples, and included field blanks and duplicate groundwater samples. The QC data from the chemical analysis of field blanks and duplicate groundwater samples obtained in 2005 are provided in Klohe and Debrewer (2007). The QC data from the chemical analysis of field blanks and duplicate groundwater samples obtained in 2008 are provided in this report (table A2).

Additional QC data were provided by the USGS analytical laboratories on the performance of their methods. Laboratory QC data included (a) the recoveries of pesticidesurrogate compounds added to each groundwater or QC sample at the time of analysis, and (b) the laboratory detection and reporting levels, determined from estimates of method precision for each pesticide. Pesticide surrogate recoveries, long-term method detection levels (LT-MDLs), and laboratory reporting levels (LRLs) data for 2005 and 2008 are provided in this report in conjunction with their use in the assessment of the quality of groundwater pesticide data.

Comparisons were made of (a) field and laboratory QC samples obtained for each year of data collection, (b) the laboratory methods used for each year of data collection, including the addition of new compounds to previously existing schedules, and (c) general observations of site characteristics associated with the wells. The degree to which data from both years could be combined and compared for analysis and interpretation is evaluated.

Field blanks typically are collected to assess whether sampling apparatus were adequately cleaned before reuse, and whether chemical sample preservatives, or the collection, processing, shipping, and laboratory analysis of samples led to contamination of the samples (Koterba and others, 1995). Sequential (duplicate) groundwater samples assess the consistency of measurement precision of a given analytical constituent (Koterba and others, 1995). Pesticide surrogate recovery data from laboratory-spiked groundwater samples, and the analytical method detection and reporting were used to compare method performance between 2005 and 2008 (Koterba and others, 1995).

\section{Contamination Bias}

Klohe and Debrewer (2007) found that except for the presence of low levels of 10 of 32 major ions and selected trace elements, no other compounds, including any pesticides, were detected at concentrations that exceeded LRLs in three field blanks collected at different times and well locations in 2005. No pesticides were detected in these field blanks at concentrations equal to or greater than the LT-MDLs. Results from a source-water blank indicated that for the 10 detected inorganic constituents, the lot of blank water used had a higher than normal $\mathrm{pH}$, specific conductance, and concentrations of aluminum, barium, and strontium. Overall, and except for aluminum, the authors concluded that the low concentrations of the 10 inorganic constituents present in one or both field blanks appeared negligible compared to the concentrations typically found in groundwater samples. Therefore, except for aluminum, no bias from contamination appears to have been introduced during sample processing or analysis in 2005 that would limit interpretation of the groundwater data, including the pesticide data. For aluminum, field blanks had concentrations about three to seven times greater than the median concentration ( 2.2 micrograms per liter, $\mu \mathrm{g} / \mathrm{L})$ found in groundwater samples (Klohe and Debrewer, 2007). Use of this blank water temporarily could have contaminated equipment when blanks were collected. The groundwater samples collected immediately after these field blanks at wells AC Aa 1, WE Ba 10, WE Ca 33, however, had aluminum concentrations that ranged from the less than $2 \mu \mathrm{g} / \mathrm{L}$ (LRL) to $4 \mu \mathrm{g} / \mathrm{L}$, which is near the median value for aluminum in groundwater samples collected in $2005(2.22 \mu \mathrm{g} / \mathrm{L})$. Thus, if the process of running blanks through the equipment temporarily did introduce aluminum into groundwater samples collected immediately after the blanks, the contamination was minor in magnitude and at most resulted in low, but measureable, concentrations of aluminum in those particular groundwater samples.

Conclusions similar to those drawn from the field-blank data obtained in 2005 can be drawn from the analysis of the field-blank data collected in 2008 (table A2). Except for trace amounts of selected major ions and trace elements, the concentrations of all constituents, including all pesticides, analyzed in two field-blank samples were less than the LRLs. No pesticides were detected in the field blanks.

For each of the constituents detected in one or more field blanks in 2008 (table B1), the blank concentration was near, or considerably less than, the minimum concentration, and well below the median concentration, found in groundwater samples. As was the case in 2005, the 2008 field-blank data indicated no appreciable bias was introduced during the processing and analyses of samples that would limit interpretation of the pesticide and other groundwater data.

\section{Measurement Precision}

The degree of precision in the measurement of concentrations of pesticides and other constituents was evaluated with two sets of sequentially collected duplicate groundwater samples.

Results of analyses of the duplicate samples obtained from each of two different wells in 2005 indicated that duplicate measureable values were reasonably precise for most inorganic and organic constituents (Klohe and Debrewer, 2007). The uncertainty in duplicate measurements, estimated 
Table B1. Concentrations in field blanks and groundwater samples with constituents detected in at least one field blank collected during groundwater sampling in Washington, D.C. in 2008.

$\left[\mathrm{mg} / \mathrm{L}\right.$, milligrams per liter; $\mu \mathrm{g} / \mathrm{L}$, micrograms per liter; $\mathrm{CaCO}_{3}$, calcium carbonate; <, concentration is below the laboratory reporting level (LRL) for the constituent; E, quantified above the long-term method detection limit but below the laboratory reporting level with higher uncertainty; std, standard]

\begin{tabular}{|c|c|c|c|c|c|c|c|c|}
\hline \multirow[b]{2}{*}{$\begin{array}{l}\text { Type of } \\
\text { sample }\end{array}$} & \multirow[b]{2}{*}{$\begin{array}{l}\text { Number of } \\
\text { samples }\end{array}$} & \multirow[b]{2}{*}{ Statistic } & \multicolumn{6}{|c|}{ Water-quality constituent and actual or range in concentration } \\
\hline & & & $\begin{array}{l}\text { Calcium } \\
\text { (mg/L) }\end{array}$ & $\begin{array}{l}\text { Sodium } \\
\text { (mg/L) }\end{array}$ & $\begin{array}{c}\text { Carbonates }^{1} \\
\text { (mg/L as } \\
\left.\mathrm{CaCO}_{3}\right)\end{array}$ & $\begin{array}{c}\text { Fluoride } \\
\text { (mg/L) }\end{array}$ & $\begin{array}{l}\text { Iron } \\
(\mu \mathrm{g} / \mathrm{L})\end{array}$ & $\begin{array}{c}\text { Manganese } \\
(\mu \mathrm{g} / \mathrm{L})\end{array}$ \\
\hline Field blank 1 & 1 & Concentration & $<0.04$ & $<0.12$ & E 3 & $<0.12$ & $<8$ & $<0.4$ \\
\hline Field blank 2 & 1 & Concentration & 0.06 & E 0.09 & E 3 & E 0.11 & E 4 & E 0.03 \\
\hline Groundwater & 14 & $\begin{array}{l}\text { Median } \\
\text { concentration }\end{array}$ & $41.8 / 48.2$ & $16.6 / 20.1$ & 18.8 & $<0.12$ & $<0.8 / 51$ & $465 / 539$ \\
\hline
\end{tabular}

\footnotetext{
${ }^{1}$ Calculated from the acid neutralization capacity determined from unfiltered field blanks and from the alkalinity determined for filtered groundwater
} samples; only 13 samples were analyzed for carbonates as alkalinity was not determined for one sample that had a $\mathrm{pH}$ of less than 4.3 .

as the relative percent difference (RPD), typically was 10 percent or less. The RPD exceeded 10 percent for several trace elements (cadmium, copper, uranium, and zinc), nitrite and organic nitrogen, and caffeine.

Evaluation of data obtained from sequential duplicate groundwater samples collected at each of two wells in 2008 revealed precision results similar to the results described above for the groundwater data collected in 2005 (table B2). With the exception of iron in one set of duplicate samples, the RPD in duplicate-sample concentrations for most inorganic constituents was less than 1 percent, and no more than about 10 to 12 percent (fig. B1A). For pesticides, the RPD between duplicate-sample concentrations was usually less than 10 percent, and not more than 20 percent (fig. B1B).

\section{Laboratory Methods}

All groundwater samples analyzed for pesticides by the USGS National Water Quality Laboratory (NWQL) were spiked with known amounts of pesticide surrogate compounds before analysis to assess the method recovery. Surrogate recovery results for each laboratory schedule for the groundwater samples analyzed in 2005 (Klohe and Debrewer, 2007, appendix 3) and in 2008 (table A1) were compared to determine if method performances were similar between years.

For a given NWQL pesticide laboratory schedule and surrogate, the recovery data for 2005 and 2008 were combined, transformed into ranked data, and tested for significant differences in recovery between years using a Wilcoxon-MannWhitney rank sum test (Helsel and Hirsch, 2002). Except for NWQL laboratory schedule 2060, test results indicate there are no significant differences in the recovery of a surrogate compound in 2005 samples compared to 2008 samples analyzed with the same laboratory (table B3, Wilcoxon-Mann-Whitney test on ranked surrogate recoveries: significance level set at $\alpha=.05$ for a one- or two-tailed test). For NWQL schedule 2060, ranked recoveries for each surrogate compound in 2005 were significantly different from the ranked surrogate recoveries in 2008. Mean surrogate recoveries in 2005 samples were 39, 24, and 15 percent higher than in 2008 samples for 2,4,5-trichlorophenol, barban, and caffeine-13C, respectively.

The difference in 2,4,5-trichlorophenol recoveries between 2005 and 2008 appears to mainly result from high individual spiked-sample recoveries in 2005. Thirteen of 17 spiked-sample recoveries for this surrogate compound in 2005 were between 101 percent and 154 percent. Each of these 13 recovery values was estimated (E coded), which generally indicates sample-matrix interference and (or) spiking problems.

The difference in barban surrogate recoveries between 2005 and 2008 also appeared to result in part from elevated and estimated recoveries of this surrogate compound in 2005 - where 11 of 17 recoveries of barban from spiked samples in 2005 ranged from 104 to 162 percent. In addition, there were two unusually low spiked-sample recoveries for barban in 2008-54 percent for WE Ca 34 and 34 percent for WW Bc 10.

The mean recovery of caffeine-13C in 2005 groundwater samples was about 15 percent greater than its mean recovery in 2008 groundwater samples. This difference (bias) in recoveries is not unusual given year-to-year variations in laboratory performance in estimating low-level pesticide concentrations.

Collectively, the main effect of the notably higher recoveries of at least two of the surrogate compounds in 2005 groundwater samples compared to their recoveries in 2008 groundwater samples is that the higher recoveries led to an increase in the LRLs (and LT-MDLs) for selected pesticide compounds in 2005 compared to the censoring levels for these same compounds in 2008 (table B4). For example, comparison 
Table B2. Means and relative percent differences in the concentrations of inorganic and organic constituents obtained from two sequential duplicate groundwater samples collected from wells in Washington, D.C. in 2008.

[RPD, relative percent difference, calculated as the difference between the two duplicate-sample concentrations, divided by their mean concentration, expressed in percent; ---, concentration in one or both of the duplicate samples was below laboratory reporting level; USGS, U.S. Geological Survey; mg/L, milligrams per liter; $\mu \mathrm{g} / \mathrm{L}$, micrograms per liter]

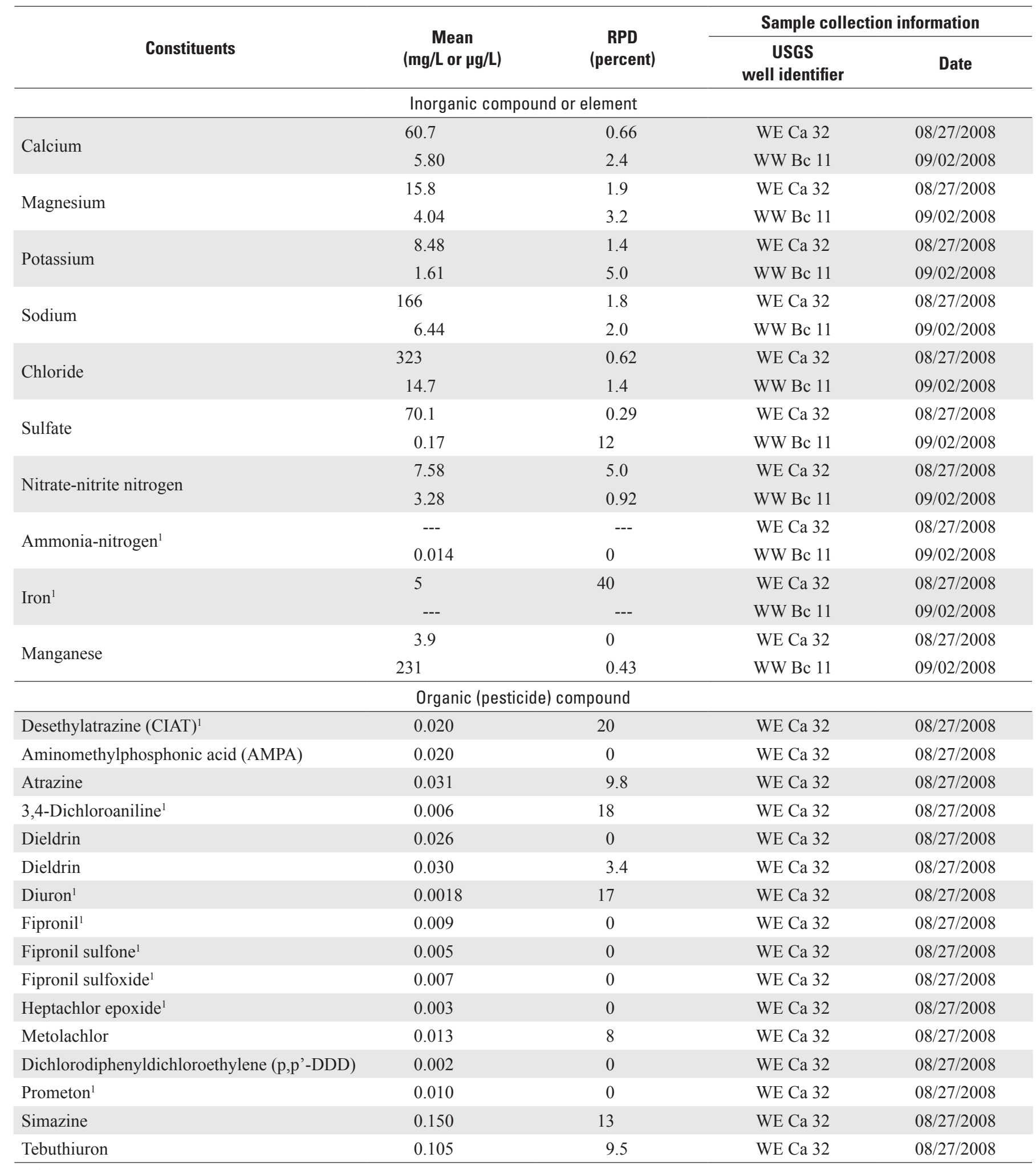

\footnotetext{
${ }^{1}$ Statistics were derived from duplicate sample concentrations that were both estimated (E-coded values), and therefore, concentrations were derived from values with inherently higher than normal uncertainty.
} 
(A) Inorganic constituents

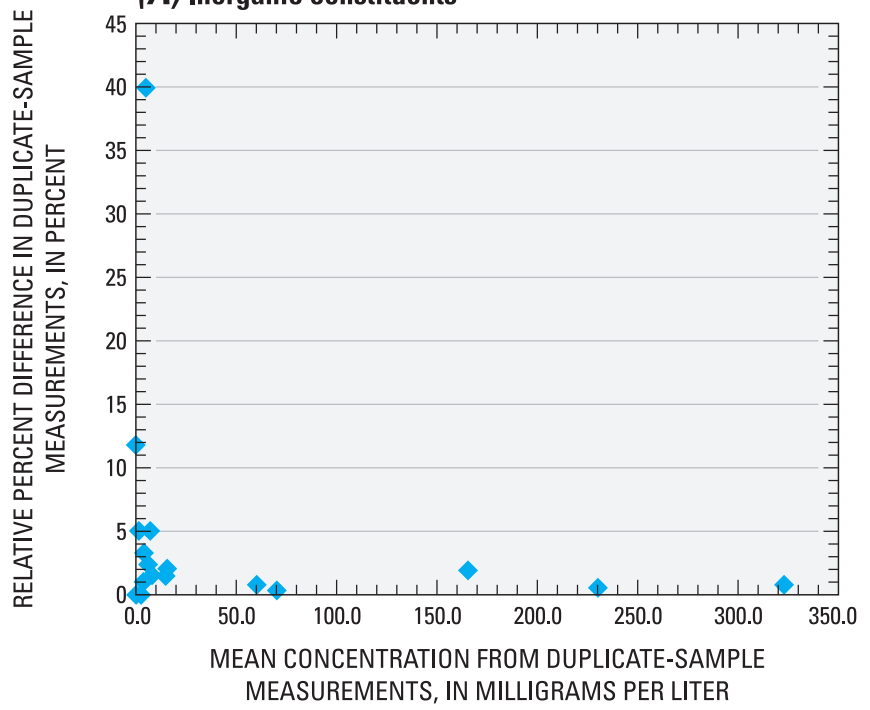

(B) Pesticides

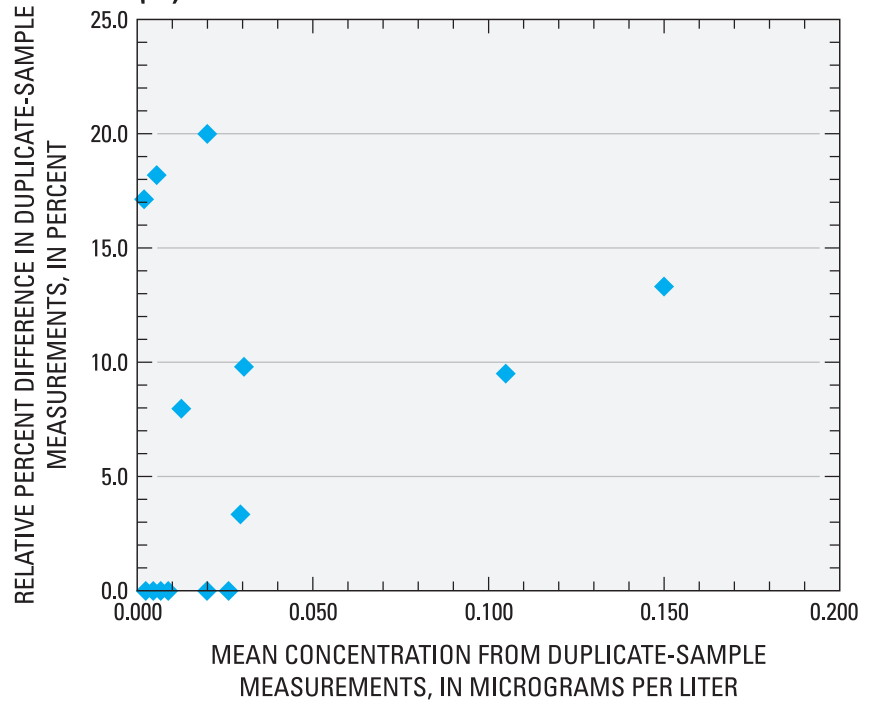

Figure B1. Relative percent difference as a function of mean concentration for: $(A)$ inorganic constituents (in milligrams per liter, $\mathrm{mg} / \mathrm{L}$ ) including calcium, magnesium, sodium, potassium, nitrate plus nitrite-nitrogen and ammonium-nitrogen, chloride, sulfate, manganese, and iron [with iron having the extreme value (40 percent) for one of two sets of duplicate measurements]; and (B) pesticides (in micrograms per liter, $\mu \mathrm{g} / \mathrm{L}$ ) including atrazine, prometon, simazine, desethylatrazine, dieldrin, fipronil, fipronil sulfone, fipronil sulfide, aminomethylphosphonic acid (AMPA), heptachlor expoxide, metolachlor, dichlorodiphenyldichloroethane (p, $p^{\prime}$-DDD), and tebuthiuron.

Table B3. Mean and relative standard deviation of pesticide surrogate compound recoveries for each laboratory method and from laboratory-spiked groundwater samples in 2005 and 2008, and results of the Wilcoxon-Mann-Whitney rank sum test to determine if ranked recoveries in 2005 differed from ranked recoveries in 2008.

[\%, percent; RSD, relative standard deviation; $n$, number of groundwater samples spiked in laboratory with the indicated surrogate compound; U, calculated sum of ranks statistic; p, power of test; $\alpha$, alpha; $\mathrm{HCH}$, Hexachlorocyclohexane; PCB, 2,2',3,3',4,4',5.6.6'-nonachlorobiphenyl; ---, Laboratory schedule 2033 was not used in 2005; LS, laboratory schedule]

\begin{tabular}{|c|c|c|c|c|c|c|c|c|c|}
\hline \multirow{2}{*}{$\begin{array}{l}\text { Laboratory schedule } \\
\text { (LS) and surrogate } \\
\text { compound }\end{array}$} & \multicolumn{3}{|c|}{2005} & \multicolumn{3}{|c|}{2008} & \multicolumn{3}{|c|}{ Wilcoxon-Mann-Whitney rank sum test ${ }^{1}$} \\
\hline & $\begin{array}{c}\text { Mean } \\
\text { recovery } \\
(\%)\end{array}$ & $\begin{array}{l}\text { RSD } \\
(\%)\end{array}$ & $\mathbf{n}$ & $\begin{array}{l}\text { Mean } \\
\text { recovery } \\
(\%)\end{array}$ & $\begin{array}{l}\text { RSD } \\
(\%)\end{array}$ & $\mathbf{n}$ & $\begin{array}{l}\text { U, Rank sum } \\
\text { statistic, } \\
\text { calculated }\end{array}$ & $\begin{array}{c}\text { p, for 2-tailed } \\
\text { test, } \alpha=0.05\end{array}$ & $\begin{array}{c}\text { p, for 1-tailed } \\
\text { test, } \alpha=0.05\end{array}$ \\
\hline \multicolumn{10}{|l|}{ LS 2060} \\
\hline 2,4,5-Trichlorophenol ${ }^{2}$ & 114 & 20 & 17 & 75 & 16 & 14 & 224 & 0.000004 & 0.000002 \\
\hline \multicolumn{10}{|l|}{ LS 1398} \\
\hline alpha-HCH-d6 & 98 & 8.3 & 17 & 101 & 12 & 14 & 134 & 0.57 & 0.28 \\
\hline Isodrin & 90 & 10 & 17 & 82 & 14 & 14 & 167 & 0.06 & 0.03 \\
\hline PCB, 207 & 105 & 12 & 17 & 106 & 8.4 & 14 & 129 & 0.71 & 0.35 \\
\hline
\end{tabular}

\footnotetext{
${ }^{1}$ Helsel and Hirsch (2002).

${ }^{2}$ In 2005, recoveries from most individual samples were estimated and are commonly near 100 percent. Also in 2008, and for samples collected from wells WE Ca 34 and WW Bc 10, barban recoveries are unusually low, 54 percent and 38 percent, respectively.

${ }^{3}$ In 2008, and for the sample collected from well WW Bc 10, barban recovery was unusually high (199 percent), indicating that sample possibly was spiked twice with this surrogate.
} 
between 2005 and 2008 for the LT-MDLs and LRLs in NWQL schedule 2060 indicates that both censoring levels for metsulfuron methyl and tebuthiuron were notably higher in 2005 than those in 2008. These compounds, however, were seldom detected in groundwater in either year of data collection.

There was no evidence that the differences between surrogate recoveries in 2005 and 2008 affected the quantification of individual pesticide concentrations in groundwater samples analyzed with NWQL schedule 2060. For example, few if any estimated concentrations (compounds that were detected and quantified below the LRL) appear for schedule 2060 in the 2005 groundwater samples (Klohe and Debrewer, 2007, appendix 3), or for that matter, for any laboratory schedule in 2008 samples (appendix A, table A1, this report).

All of the evidence above indicates that the higher surrogate recoveries in NWQL schedules 2060 in 2005 likely reflect analytical differences related to the individual surrogates and not the detection and quantification of most compounds. Given there also appeared to be no significant differences in the surrogate recoveries between years associated with the other NWQL schedules used for pesticide analysis in both years (table B3), the basis by which to determine whether pesticide data could be combined for both years for interpretive purposes were (a) whether there were notable differences between years for LRLs and LT-MDLs in the same schedule and (b) whether the use of the additional laboratory schedule in 2008 added to the number of pesticides detected in groundwater.

A comparison of the LRLs and LT-MDLs in 2005 with those in 2008 for pesticide compounds analyzed with the same laboratory method and detected at least once in either or both years (table B4) indicated that:

a. Compounds with higher LRLs and (or) LT-MDLs in 2005 compared to those in 2008 were atrazine, CIAT, metsulfuron methyl, tebuthiuron, glyphosate, and AMPA;

b. Compounds with similar LRLs and (or) LT-MDLs in 2005 and 2008 were atrazine, CIAT, bromacil, p,p'DDE, dieldrin (schedule 2033), chlordane, fipronil sulfide and sulfone; and

c. Compounds which had lower LRLs and (or) LT-MDLs in 2005 compared to those in 2008 were OIET, diuron, fluometuron, dieldrin (schedule 1398), imidacloprid, heptachlor epoxide, fipronil, and sulfometuron methyl.

In relation to (a) above, more detections generally occurred for these pesticide compounds in groundwater samples collected in 2008 than were detected in groundwater samples collected in 2005. This result is consistent with the differences in the LRLs and (or) LT-MDLs in 2005 and 2008. In relation to (b) and (c), however, more or as many detections generally occurred for most of the pesticide compounds in groundwater samples collected in 2008 than were detected in groundwater samples collected in 2005. The results for (b) and (c) are inconsistent with the differences in LRLs and LT-MDLs between years, and imply factors other than laboratory method performance affected pesticide detections. To address this issue, pesticide detections were compared for the most frequently detected compounds in either year of data collection for those laboratory schedules used in both years to analyze groundwater samples collected from the same seven wells in both years (table B5).

The comparison of pesticide detections in samples from wells used in both years with similar laboratory schedules generally supports the hypothesis that differences in the detection of pesticides occurred between years (table B5). It also appears that these differences possibly occurred in part as a result of changes in the performance of analytical methods in 2005 and 2008. Only six pesticides were detected in 2005 samples that were not redetected in the corresponding 2008 samples (table B5). In two cases (imidacloprid and metsulfuron methyl) the LRLs in 2005 were notably less than the LRLs in 2008. For most of these compounds, however, degradation could have led to a decline in the concentration of these compounds in groundwater from 2005 through 2008, and, thus, an inability to detect these compounds in groundwater samples in 2008. Of greater importance is that considerably more pesticide detections (16) occurred in 2008 than 2005 (table B5). Most of these detections are for compounds present at low concentrations, and likely were detected in 2008 but not in 2005 because of the lower LRLs (and hence LT-MDLs, Table B4) in 2008 than the corresponding LRLs (and LT-MDLs) in 2005.

Other method-related factors possibly could be postulated to account for more frequent pesticide detections in $2008 \mathrm{com}$ pared to 2005. The differences could reflect the inability of the methods to accurately reproduce pesticide concentrations chiefly near or below the LRLs in both years of data collection. Given the uncertainty in the measurements of most of the detected pesticides at low concentrations (table B2), it would be a challenge to repeatedly detect and quantify pesticides present at what are relatively low concentrations. One would expect, however, that such variations in detections would be random for each compound, and not biased towards improved detections for each of a number of different pesticide compounds in one year compared to another year, which was the case given the results described above.

Differences in the frequency of pesticide detections between 2005 and 2008 could have occurred because of the introduction of an additional laboratory method (NWQL schedule 2033) and because of new pesticide compounds added to the laboratory methods previously used in 2005 . These additions enabled the detection of 10 chiefly polar pesticide compounds using NWQL schedule 2033 and three additional nonpolar pesticide compounds using the revised schedules (table B6). Collectively, these method additions led to the frequency of detections in 2008 samples of (a) the $s$-triazines, simazine and prometon; (b) the chloracetanilides, alachlor and metolachlor; (c) the phenopyrazoles, fipronil and its sulfide and sulfone degradates; (d) a degradate of diuron, 3,4-dichloroaniline; and (e) the organochlorine insecticide, chlorpyrifos. Each of these compounds was detected in one or 
Table B4. U.S. Geological Survey laboratory reporting and detection levels for pesticide schedules used in 2005 and 2008, and for which at least one pesticide was detected in a groundwater sample in 2005 or 2008.

[USGS, U.S. Geological Survey; LRL, laboratory reporting level; LT-MDL, long-term method detection limit; $\mu \mathrm{g} / \mathrm{L}$, micrograms per liter; CEAT, 2-chloro-4ethylamino-6-amino-s-triazine; CIAT, desethylatrazine; OIET, 2-chloro-4-isopropylamino-6-amino-s-triazine; AMPA, aminomethylphosphonic acid; ---, not analyzed; NA, not available; LCGY, U.S. Geological Survey Kansas laboratory code for glyphosate and degradates]

\begin{tabular}{|c|c|c|c|c|c|c|c|c|c|}
\hline $\begin{array}{l}\text { USGS } \\
\text { laboratory reporting } \\
\text { and detection levels }\end{array}$ & $\begin{array}{c}\text { Date } \\
\text { (year) }\end{array}$ & $\begin{array}{c}\text { Atrazine } \\
(\mu \mathrm{g} / \mathrm{L})\end{array}$ & $\begin{array}{c}\text { Simazine } \\
(\mu \mathrm{g} / \mathrm{L})\end{array}$ & $\begin{array}{c}\text { Prometon } \\
(\mu \mathrm{g} / \mathrm{L})\end{array}$ & $\begin{array}{l}\text { CIAT } \\
(\mu \mathrm{g} / \mathrm{L})\end{array}$ & $\begin{array}{c}\text { OIET } \\
(\mu \mathrm{g} / \mathrm{L})\end{array}$ & $\begin{array}{l}\text { CEAT } \\
(\mu \mathrm{g} / \mathrm{L})\end{array}$ & $\begin{array}{l}\text { Aceto- } \\
\text { chlor } \\
(\mu \mathrm{g} / \mathrm{L})\end{array}$ & $\begin{array}{c}\text { Metolachlor } \\
\text { ( } \mu \mathrm{g} / \mathrm{L})\end{array}$ \\
\hline LRL & 2005 & 0.008 & --- & --- & 0.028 & 0.032 & 0.08 & --- & --- \\
\hline LT-MDL & 2005 & 0.004 & --- & --- & 0.014 & 0.016 & 0.04 & --- & --- \\
\hline LRL & 2008 & 0.007 & 0.006 & 0.01 & 0.014 & 0.040 & 0.08 & 0.006 & 0.010 \\
\hline LT-MDL & 2008 & 0.004 & 0.003 & 0.002 & 0.007 & 0.020 & 0.04 & 0.003 & 0.005 \\
\hline
\end{tabular}

\begin{tabular}{|c|c|c|c|c|c|c|c|c|c|}
\hline $\begin{array}{l}\text { USGS } \\
\text { laboratory reporting } \\
\text { and detection levels }\end{array}$ & $\begin{array}{l}\text { Date } \\
\text { (year) }\end{array}$ & $\begin{array}{c}\text { Metsulfuron } \\
\text { methyl } \\
(\mu \mathrm{g} / \mathrm{L})\end{array}$ & $\begin{array}{c}\text { Bromacil } \\
(\mu \mathrm{g} / \mathrm{L})\end{array}$ & $\begin{array}{c}\text { Tebuthiuron } \\
(\mu \mathrm{g} / \mathrm{L})\end{array}$ & $\begin{array}{c}\text { Chlorpyrifos } \\
(\mu \mathrm{g} / \mathrm{L})\end{array}$ & $\begin{array}{c}\text { p,p'-DDD } \\
(\mu g / L)\end{array}$ & $\begin{array}{c}\text { p,p'-DDE } \\
(\mu \mathrm{g} / \mathrm{L})\end{array}$ & \multicolumn{2}{|c|}{$\begin{array}{c}\text { Dieldrin } \\
\text { (2 methods) } \\
\text { ( } \mu \mathrm{g} / \mathrm{L})\end{array}$} \\
\hline LT-MDL & 2005 & NA & 0.009 & 0.013 & --- & 0.0012 & 0.0009 & 0.004 & 0.0005 \\
\hline LRL & 2008 & 0.14 & 0.02 & 0.016 & 0.005 & 0.0012 & 0.0019 & 0.009 & 0.0016 \\
\hline $\begin{array}{l}\text { USGS } \\
\text { laboratory reporting } \\
\text { and detection levels }\end{array}$ & $\begin{array}{l}\text { Date } \\
\text { (year) }\end{array}$ & $\begin{array}{c}\text { Glyphosate } \\
\text { ( } \mu \mathrm{g} / \mathrm{L})\end{array}$ & $\begin{array}{l}\text { AMPA } \\
(\mu \mathrm{g} / \mathrm{L})\end{array}$ & $\begin{array}{c}\text { Fipronil } \\
\text { ( } \mu \mathrm{g} / \mathrm{L})\end{array}$ & $\begin{array}{l}\text { Fipronil } \\
\text { sulfide } \\
\text { ( } \mu \mathrm{g} / \mathrm{L})\end{array}$ & $\begin{array}{l}\text { Fipronil } \\
\text { sulfone } \\
\text { ( } \mu \mathrm{g} / \mathrm{L})\end{array}$ & $\begin{array}{c}\text { Sulfome- } \\
\text { turon } \\
\text { methyl } \\
(\mu \mathrm{g} / \mathrm{L})\end{array}$ & $\begin{array}{c}\text { Diuron } \\
(\mu \mathrm{g} / \mathrm{L})\end{array}$ & $\begin{array}{c}\text { 3,4-Di- } \\
\text { chloroaniline } \\
\text { ( } \mu \mathrm{g} / \mathrm{L})\end{array}$ \\
\hline LRL & 2005 & 0.15 & 0.31 & 0.016 & 0.013 & 0.024 & 0.038 & 0.015 & --- \\
\hline
\end{tabular}

\begin{tabular}{l|c|c|c|c|c}
\hline $\begin{array}{c}\text { USGS } \\
\text { laboratory reporting } \\
\text { and detection levels }\end{array}$ & $\begin{array}{c}\text { Date } \\
(\mathbf{y e a r})\end{array}$ & $\begin{array}{c}\text { Fluometuron } \\
(\boldsymbol{\mu g} / \mathbf{L})\end{array}$ & $\begin{array}{c}\text { Imi- } \\
\text { dachlo- } \\
\mathbf{p r i d} \\
(\boldsymbol{\mu g} / \mathbf{L})\end{array}$ & $\begin{array}{c}\text { Chlordane } \\
(\boldsymbol{\mu g} / \mathbf{L})\end{array}$ & $\begin{array}{c}\text { Heptachlor } \\
\mathbf{e p o x i d e} \\
(\boldsymbol{\mu g} / \mathbf{L})\end{array}$ \\
\hline LRL & 2005 & 0.016 & 0.020 & 0.1 & 0.0012 \\
LT-MDL & 2005 & 0.008 & 0.010 & NA & 0.0006 \\
\hline LRL & 2008 & 0.04 & 0.06 & 0.1 & 0.0016 \\
LT-MDL & 2008 & 0.02 & 0.03 & NA & 0.0008 \\
\hline
\end{tabular}


Table B5. Pesticide detections and concentrations in groundwater samples collected from wells sampled in 2005 and 2008 and analyzed for similar compounds using the same laboratory schedules in 2005 and 2008.

[USGS, U.S. Geological Survey; $\mu \mathrm{g} / \mathrm{L}$, micrograms per liter; <, less than; E, quantified above the long-term method detection limit but below the laboratory reporting level with higher uncertainty; ---, not analyzed; shaded data reflect analyses with lab schedule 2060, and unshaded are from schedule 2033, USGS National Water Quality Laboratory]

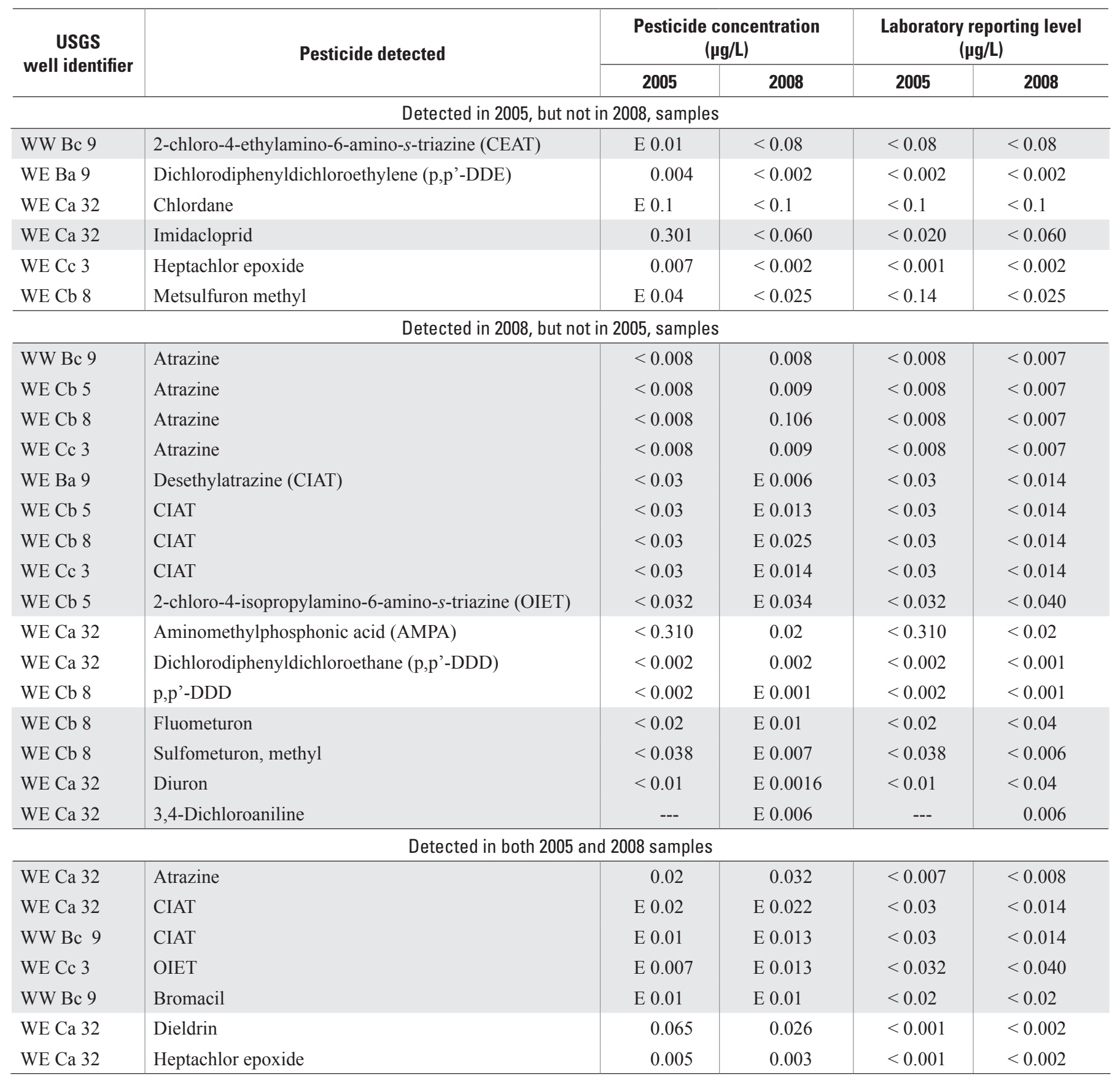


Table B6. Pesticide detections in groundwater attributed to the addition of a laboratory schedule (LS 2033) in 2008 that was not used in 2005 , or the addition of new pesticide compounds into laboratory schedules.

[USGS, U.S. Geological Survey; $\mu \mathrm{g} / \mathrm{L}$, micrograms per Liter; ---, not analyzed; <, less than; E, quantified above the long-term method detection limit but below the laboratory reporting level with higher uncertainty; shaded data indicate wells that also were used for data collection in 2005 but without the additional laboratory schedule or additional compounds]

\begin{tabular}{|c|c|c|c|c|}
\hline \multirow{2}{*}{$\begin{array}{c}\text { USGS } \\
\text { well identifier }\end{array}$} & \multirow[t]{2}{*}{ Pesticide residue } & \multicolumn{2}{|c|}{$\begin{array}{l}\text { Sample concentration } \\
(\mu \mathrm{g} / \mathrm{L})\end{array}$} & \multirow{2}{*}{$\begin{array}{c}2008 \text { laboratory } \\
\text { reporting level } \\
(\mu \mathrm{g} / \mathrm{L})\end{array}$} \\
\hline & & 2005 & 2008 & \\
\hline \multicolumn{5}{|c|}{2008 detections associated with the use of laboratory schedule 2033} \\
\hline WW Bc 9 & Simazine & --- & E 0.006 & $<0.006$ \\
\hline WE Cb 5 & Simazine & --- & 0.01 & $<0.006$ \\
\hline WE Cc 3 & Simazine & --- & 0.008 & $<0.006$ \\
\hline WE Ba 11 & Simazine & --- & 0.022 & $<0.006$ \\
\hline WE Ca 32 & Simazine & --- & 0.016 & $<0.006$ \\
\hline WE Cb 5 & Prometon & --- & E 0.01 & $<0.01$ \\
\hline WE Cc 3 & Prometon & --- & E 0.01 & $<0.01$ \\
\hline WE Ca 32 & Prometon & --- & E 0.01 & $<0.01$ \\
\hline WE Cc 3 & Fipronil & --- & E 0.005 & $<0.020$ \\
\hline WE Ca 32 & Fipronil & --- & E 0.009 & $<0.020$ \\
\hline WE Ca 32 & Fipronil sulfide & --- & E 0.007 & $<0.013$ \\
\hline WE Cc 3 & Fipronil sulfide & --- & E 0.007 & $<0.013$ \\
\hline WE Ca 32 & Fipronil sulfone & --- & E 0.005 & $<0.024$ \\
\hline WE Cb 8 & Acetochlor & --- & 0.019 & $<0.006$ \\
\hline WW Bc 9 & Metolachlor & --- & E 0.008 & $<0.010$ \\
\hline WE Cb 8 & Metolachlor & --- & 0.053 & $<0.010$ \\
\hline WW Ac 8 & Metolachlor & --- & E 0.008 & $<0.010$ \\
\hline WE Ca 32 & Metolachlor & --- & 0.013 & $<0.010$ \\
\hline \multicolumn{5}{|c|}{2008 detections associated with compound additions to laboratory schedules } \\
\hline WE Cb 8 & Chlorpyrifos & --- & E 0.005 & $<0.005$ \\
\hline We Ca 32 & 3,4-Dichloroaniline & --- & E 0.006 & $<0.006$ \\
\hline WE Cb 8 & Sulfameturon methyl & --- & E 0.007 & $<0.030$ \\
\hline
\end{tabular}

more groundwater samples in 2008 and, except for simazine in well WE Ba 11 and metolachlor in well WW Ac 8, all of these pesticides were detected in samples taken from wells that were previously sampled in 2005 .

\section{Site-Specific Observations}

During field visits in 2008, it was observed that a leaking fire hydrant near well WE $\mathrm{Cb} 8$ had been draining into and saturating the area around the wellhead for an indeterminate period of time. The groundwater sample collected from this well in 2008 contained eight pesticide and (or) degradate compounds (table B6). Only one pesticide was detected in the groundwater sample collected from this well in 2005 (metsulfuron methyl, at E $0.04 \mu \mathrm{g} / \mathrm{L}$ ). This pesticide was not detected in 2008, although most likely because there were notable increases in the LRL and LT-MDL for this compound after 2005 (table B4), implying its detection in 2005 is suspect and quantification was at a high level of uncertainty. Given all of the above and given that the screened interval of well WE $\mathrm{Cb} 8$ is 255 to 265 feet below land surface with an intervening 215-feet-thick clay layer (table 4), the water-quality data, including pesticide data, for 2005 and 2008 for this well may not accurately reflect the groundwater at this site. 


\section{Summary and Implications for Analysis and Interpretation}

Quality-control data from blanks and duplicate sequential groundwater samples obtained in the field, and from laboratory surrogate recovery data, were analyzed to assess the quality of the groundwater data collected from 17 monitoring wells in the lower Anacostia River watershed in 2005, and from 14 monitoring wells in the Anacostia River and Rock Creek watersheds in 2008. Results of this analysis indicate the following:

a. For both years, field-blank data indicate no appreciable bias due to contamination was introduced during the processing and analysis of groundwater samples that would limit interpretation of the data. Except for trace amounts of selected major ions, the concentrations of all groundwater constituents, including all pesticides, in field-blank samples were less than their respective method LRLs. No pesticides were detected in any field blanks. For each constituent that was detected in one or more field blanks, the blank concentration was found to be near, or considerably less than, the minimum concentration and generally well below the median concentration in groundwater samples collected in either year.

b. For both years, sequential duplicate groundwater samples collected from selected wells revealed similar precision results-low variability in duplicate measurements for most constituents. For inorganic constituents at measureable concentrations in duplicate samples, the relative percent difference between the two concentrations for most constituents was near or less than 12 percent, and often less than 1 percent. For pesticides at measureable concentrations in duplicate samples, the relative percent difference between the two concentrations generally was 20 percent or less, and for most organic constituents less than 10 percent.

c. For the 2 years in which data were collected, differences in the type and number of pesticides detected in groundwater samples collected in 2005 and 2008 could be due in part to differences in analytical methods. Variations in method performance based on LRLs and LT-MDLs possibly led to six pesticide detections in
2005 samples that were not repeated in 2008 samples collected from the same wells. Lower censoring levels for other pesticide compounds in 2008 compared to those in 2005 possibly led to 16 detections in groundwater samples collected in 2008, most of which (10 of 16) were not initially detected in groundwater samples collected from the same wells earlier in 2005. Also in 2008, the addition of pesticide method NWQL schedule 2033 resulted in a large number of pesticide detections (18) for 6 polar compounds. No analyses for these polar compounds, however, were conducted in 2005 , and most of the detected compounds (16 of 18 ) in 2008 came from wells previously used for data collection in 2005. In addition, three new pesticide compounds were added to the laboratory methods used in 2008, and were each detected once in groundwater samples collected in 2008 from two different wells.

Data-quality review from (a) and (b) above indicate pesticide and other water-quality data collected in each year could be combined for interpretive purposes. Review results from (c) above, however, indicate there are limitations in the extent to which pesticide data from both years can be compared. Pesticide data obtained from the same seven wells in 2005 and 2008 differed at least in part because of year-to-year differences in laboratory analytical methods. In addition, only 7 of 14 wells used to obtain data in 2005 were reused in 2008 . Therefore, constraints were placed on the extent to which the pesticide data were combined and interpreted.

Only simple descriptions and analyses were conducted on the occurrence and distribution of pesticides in shallow groundwater, and for the assessment of pesticide occurrence in relation to land use, surficial-aquifer sediment types, and groundwater chemistry. No major statistical analyses or hypothesis testing were conducted. Selected pesticide data were combined in order to describe the general types of pesticides present in groundwater, and their concentrations in relation to human-health and aquatic-health criteria and guidelines. Pesticide detections and some selected landscape and hydrogeologic data were combined in order to identify potential relations (future testable hypotheses) between pesticide occurrence in groundwater and selected subsurface characteristics. If combined data were used, the results were qualified to the extent possible in relation to limitations in the combined data. 
Prepared by USGS West Trenton Publishing Service Center. Edited by Ruth M. Larkins and Valerie M. Gaine.

Graphics and layout by Timothy W. Auer.

For additional information, contact:

Director, MD-DE-DC Water Science Center

U.S. Geological Survey

5522 Research Park Drive

Baltimore, MD 21228

or visit our Web site at: http://md.water.usgs.gov 
